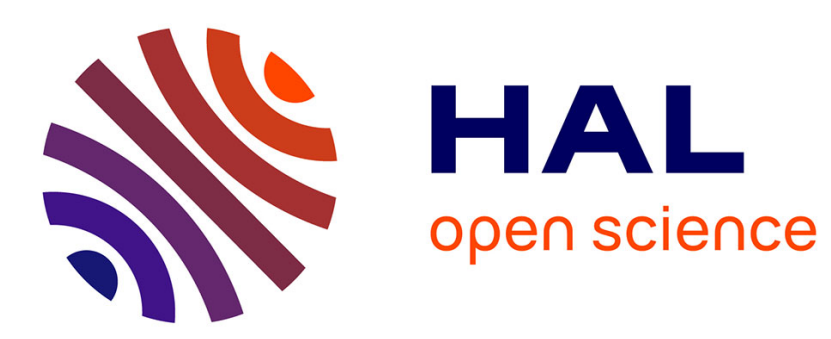

\title{
Smithian (Early Triassic) ammonoid faunas from Timor: taxonomy and biochronology.
}

\author{
Romain Jattiot, Hugo Bucher, Arnaud Brayard
}

\section{To cite this version:}

Romain Jattiot, Hugo Bucher, Arnaud Brayard. Smithian (Early Triassic) ammonoid faunas from Timor: taxonomy and biochronology.. Palaeontographica A, 2020, 317 (1-6), pp.1-137. $10.1127 /$ pala/2020/0096 . hal-02615367

\section{HAL Id: hal-02615367 \\ https://hal.science/hal-02615367}

Submitted on 6 Nov 2020

HAL is a multi-disciplinary open access archive for the deposit and dissemination of scientific research documents, whether they are published or not. The documents may come from teaching and research institutions in France or abroad, or from public or private research centers.
L'archive ouverte pluridisciplinaire HAL, est destinée au dépôt et à la diffusion de documents scientifiques de niveau recherche, publiés ou non, émanant des établissements d'enseignement et de recherche français ou étrangers, des laboratoires publics ou privés. 


\title{
Smithian (Early Triassic) ammonoid faunas from Exotic Blocks from Timor: taxonomy and biochronology
}

\author{
ROMAIN JATTIOT ${ }^{1,2, *}$, HUGO BUCHER ${ }^{1}$ and ARNAUD BRAYARD ${ }^{2}$
}

With 33 plates, 59 text-figures and 1 table

\section{Published in: Palaeontographica A 317: 1-137}

\author{
${ }^{1}$ Paläontologisches Institut der Universität Zürich, Karl Schmid-Strasse 4, 8006, Zürich, Switzerland \\ 2 Biogéosciences, UMR 6282, CNRS, Université Bourgogne Franche-Comté, 6 boulevard Gabriel, 21000 Dijon, France \\ * Correspronding author: romain.jattiot@pim.uzh.ch
}

\begin{abstract}
Two extensive collections retrieved from Exotic Blocks from West Timor have yielded several astonishingly well-preserved and highly diversified Smithian (Early Triassic) ammonoid faunas (Kashmirites fauna, Owenites fauna, Anasibirites fauna). A population approach on this material, with an emphasis on ontogeny and covariation of morphological characters, led to the unprecedented assessment of intraspecific variation for many species. Based on this, their synonymy is thoroughly discussed whenever possible. One new genus (Roopnarinites) and five new species (Paraspidites bicarinatus, Flemingites lidakensis, Subflemingites bihatiense, Baidites obesus and Churkites warei) are described. These results have a direct impact on the resolution and accuracy of biochronological correlations, as well as on the accuracy of diversity counts at the species level, which is important for potential future broad-scale diversity analyses. This material also provides highly valuable data for comprehensive biogeographical and phylogenetic studies hopefully to come. Finally, these new Timor data strengthen the singularly uniform biogeographical distribution of the Smithian ammonoid faunas within the Tethys.
\end{abstract}

Keywords: Ammonoids; Early Triassic; Smithian; Timor

Contents

1 Introduction.

2 Geological setting

3 Systematic palaeontology

Acknowledgements.

References.

List of the described ammonoids

Plates 1-33 and explanation of plates.

\section{Introduction}

Ammonoid cephalopods were among the organisms most affected by the Permian-Triassic boundary mass extinction (about 251.96 Ma, BARESEL et al. 2017). However, it is now well established that ammonoids recovered very fast in the aftermath of this crisis (BRAYARD et al. 2009a; ZAKHAROV \& ABNAVI 2013; ZAKHAROV \& POPOV 2014; BRAYARD \& BUCHER 2015).

In this context, the Smithian is a critical time interval within the Early Triassic: the main rediversification of ammonoids occurred in the early and middle Smithian, then immediately followed by the most severe intra-Triassic crisis for the nekton, in the late Smithian (BRAYARD et al. 2006; BRAYARD et al. 2009a; BRÜHWILER et al. 2010a; WARE et al. 2015; Text-fig. 1).

Oceanic basins documenting this major, global Smithian diversification-extinction cycle recently received much attention from the earth science community (e.g., western USA, BRAYARD et al. 2009b; JENKS et al. 2010; BRAYARD et al. 2013; JATTIOT et al. 2017; South China, BRAYARD \& BuCHER 2008; South Primorye, ZAKHAROV et al. 2002; SHIGETA \& ZAKHAROV 2009; SHIGETA et al. 2009; ZAKHAROV et al. 2013; Shigeta \& Kumagae 2015; South Tibet, BRÜHWILER et al. 2010b; Oman, BRÜHWILER et al. 2012a; Salt Range, BRÜHWILER et al. 2012b; Spiti, BrÜHWILER et al. 2012c; Vietnam, ShigetA \& NGUYEN 2014).

Timor Island is also long known for providing abundant Smithian ammonoids with a state of preservation often considered as unmatched in the rest of the world for this time interval. 
However, there are to our knowledge very few studies on Smithian ammonoids from Timor in the literature. After the substantial pioneering work of WELTER (1922), only SPATH (1934) and KUMMEL (1968a) examined Smithian ammonoids from Timor, and none of these three works studied a much extensive material using a statistical population approach.

Our work is based on two collections (Snyder and Veit collections, Paläontologisches Institut der Universität Zürich) that include very abundant (about 1400 measured specimens), diverse and exceptionally well-preserved Smithian ammonoids from Timor, allowing us to perform remarkably accurate taxonomic work. A part of this material has been recently studied by JATTIOT et al. (2015) in a revision of the late Smithian Anasibirites genus. Noteworthy, most of the early and middle Smithian specimens from the two collections were already fully prepared and isolated, and therefore lack stratigraphical superposition. However, on the one hand the exceptional preservation of the material led to the unprecedented assessment of intraspecific variation for many species, and to the description of unconspicuous and previously unknown features in previously described species. On the other hand, several new taxa have been found, which is important for future broad-scale diversity analyses. Finally, this material provides highly valuable data for potential biogeographical and phylogenetic studies.

\section{Geological setting}

During Early Triassic times, Timor was located in the eastern part of Pangea (c. $-15^{\circ}$ latitude and $125^{\circ}$ longitude) and off the northern Australian margin, in the transition zone between the Tethyan and Panthalassic realms. The present-day Timor Island is situated in the southeastern part of the Indonesian archipelago, $1500 \mathrm{~km}$ east of Java and $400 \mathrm{~km}$ northwest of northern Australia. The studied material was retrieved in West Timor, mainly in Lidak, Bihati (Baun) and Noe Tobe localities (Text-fig. 2).

In Timor, Early Triassic ammonoids mostly come from the prolifically fossiliferous lithologies termed the 'Cephalopod Limestone Facies' (WANNER 1911; WANNER 1913), which occurs as exotic blocks up to a few meters thick, embedded in the Cenozoic Bobonaro Formation (CHARLTON et al. 2009). These cephalopod limestones usually form highly condensed sequences but the ages represented by the different ammonoid faunas indicate that the three main subdivisions of the Smithian are present (early, middle and late Smithian). Reddish-pinkish micritic pelagic limestones (Hallstatt facies) represent the early and middle Smithian, whereas the late Smithian is characterized by a singular white lumachelle facies thoroughly described in JATTIOT et al. (2015). Early Smithian ammonoids are often coated in black ferromanganiferous minerals.

Regarding biostratigraphy, WELTER (1922) described three subdivisions in his pioneer work, namely the Meekoceras limestone (early Smithian), the Owenites limestone (middle Smithian) and the Anasibirites limestone (late Smithian). We here consider WELTER's (1922) Meekoceras limestone subdivision as inaccurate since no actual Meekoceras were identified in our early Smithian material that instead yielded numerous specimens of Kashmirites. Hence, we define three subdivisions: the Kashmirites fauna (early Smithian), the Owenites fauna (middle Smithian) and the Anasibirites fauna (late Smithian).

Comparing our new Smithian ammonoid faunas from Timor with faunal successions from wellexpanded sections from South China (BRAYARD \& BUCHER 2008), South Tibet (BRÜHWILER et al. 2010b), Pakistan (BRÜHWILER et al. 2012b) and Spiti (BRÜHWILER et al. 2012c), mixing of faunas due to condensation was evidenced in the early and middle Smithian material. Indeed, regarding the middle Smithian, the species Nyalamites angustecostatus (WELTER, 1922), Pseudoceltites multiplicatus (WAAGEN, 1895) and Truempyceras compressum BRÜHWILER et al., 2012c, used as bed markers in Tethys localities (Text-fig. 3), were found undeniably associated.

Noteworthy, the genus Brayardites was not directly found in association with Owenites in our material. However, the species Brayardites compressus BRÜHWILER et al., 2010b, Owenites simplex WELTER, 1922 and Pseudaspenites layeriformis (WELTER, 1922) were identified each on different pieces of the same block (NR10), all parts of this block sharing the exact same sedimentological facies. This suggests that the middle Smithian Brayardites compressus beds recognized below the Owenites beds in the Tethys (the Salt Range, South Tibet and Spiti) is not individualized in Timor. Thorough field investigations are thus crucial to further enhance the Smithian biostratigraphy of Timor. 


\title{
3 Systematic palaeontology
}

Systematic descriptions follow the classification established by TOzER $(1981 ; 1994)$ and then further refined by BRAYARD \& BUCHER (2008), BRÜHWILER et al. (2012a; 2012b; 2012c). The quantitative morphological range of each species is illustrated by plots provided at least three measureable specimens were available. Each set of measurements includes the classical geometric parameters of the ammonoid conch such as the shell diameter (D) and corresponding whorl height (H), whorl width (W) and umbilical diameter (U). To assess their variability within each species, these parameters are plotted as a ratio of the size-related parameter $\mathrm{D}(\mathrm{H} / \mathrm{D}, \mathrm{W} / \mathrm{D}$ and U/D) in order to remove the influence of growth.

Abbreviations: non: material not forming part of the current species; p: pars; v.: video or vidimus; ?: questionable. Repository of specimens is abbreviated PIMUZ (Paläontologisches Institut und Museum der Universität Zürich, Switzerland).

Type species: Celtites armatus WAAGEN, 1895

\author{
Subclass Ammonoidea ZiTTEL, 1884 \\ Order Ceratitida HYATT, 1884 \\ Superfamily Xenodiscaceae FRECH, 1902 \\ Family Kashmiritidae SPATH, 1934 \\ Genus Kashmirites DIENER, 1913
}

Kashmirites armatus (WAAGEN, 1895)

(Plate 1, Figs D-T)

1895 Celtites armatus WAAGEN, p. 75, pl. 7, figs 1, 7.

1922 Xenodiscus lidacensis WeLTER, p. 108, pl. 5, figs 5-7, 18; pl. 6, figs 1, 2.

1922 Xenodiscus lidacensis involutior WeLTER, p. 109, pl. 5, figs 3, 4, 11-13.

v 2012b Kashmirites armatus - BRÜHWILER \& BUCHER, p. 24, fig. 19A-M.

Occurrence: Kashmirites fauna.

Measurements: See Text-fig. 4. Estimated maximal size: $~ 7 \mathrm{~cm}$.

Description: Very evolute, serpenticonic shell with slightly flattened flanks and depressed whorls. Venter broad and subtabulate with slightly rounded but marked shoulders. Umbilicus wide with a nearly vertical wall and rounded shoulders. Ornamentation consists of distinct ribs showing great variability in spacing and shape, and becoming finer and denser at maturity. Ribs usually stop at ventral shoulders, but occasionally cross the venter as faint ridges. Suture line ceratitic with slightly phylloid saddles.

Discussion: This species mainly differs from K. nivalis (DIENER, 1897) and K. kapila (DIENER, 1897) by its more depressed whorls.

Kashmirites baidi BRÜHWILER \& BUCHER, 2012a

(Plate 1, Figs A-C)

v 2012a Kashmirites baidi BRÜHWILER \& BUCHER, p. 16, pl. 1, fig. 2.

v 2012b Kashmirites baidi - BRÜHWILER \& BUCHER, p. 25, fig. 19N-Z.

Occurrence: Kashmirites fauna. One single specimen.

Measurements: See Text-fig. 5. Estimated maximal size: $\sim 4 \mathrm{~cm}$.

Description: Very evolute, serpenticonic shell with slightly convex flanks and depressed whorls. Venter broad and subtabulate with slightly rounded but marked shoulders. Umbilicus wide, with a nearly vertical wall and rounded shoulders. Ornamentation very distinctive, consisting of simple or paired, radial ribs, becoming denser at maturity. Ribs cross the venter as broad folds at juvenile stages, and as weak ribs at maturity. Suture line not available in our material.

Discussion: Other species of Kashmirites differ from this species by an ornamentation exclusively consisting of simple ribs. The ornamentation of $K$. baidi is also much stronger on innermost whorls.

Kashmirites cf. guangxiense BRAYARD \& BUCHER, 2008

(Plate 1, Figs U-Z)

v 2008 Kashmirites guangxiense BRAYARD \& BUCHER, p. 16, pl. 1, figs 1-10.

Occurrence: Kashmirites fauna.

Measurements: See Text-fig. 6. Estimated maximal size: $~ 8.5 \mathrm{~cm}$.

Description: Very evolute, serpenticonic shell with slightly convex flanks and depressed whorls. Venter broad and slightly arched with rounded shoulders. Umbilicus with moderately high wall, inclined on outer 
whorl but nearly vertical on inner whorls. Rounded umbilical shoulders. Ornamentation consists of very broad, swollen (bullate) folds at juvenile stages, then gradually passing to rursiradiate fold-like ribs and finally to fine and dense rursiradiate ribs at maturity. Ornamentation crosses the venter. Delicate strigation visible on the inner whorls of the adult specimen. Suture line not available in our material.

Discussion: This taxon shares with K. guangxiense BRAYARD \& BUCHER, 2008 an ornamentation consisting of bullate folds at juvenile stages. However, our large specimen is much larger than the type specimens of $K$. guangxiense, thus preventing a definitive species assignment. Alternatively, the two specimens might represent extreme variants of $K$. nivalis. The type species is distinguished by its sharper and denser ornamentation.

\section{Kashmirites nivalis (DIENER, 1897)}

(Plate 2, Figs A-U)

1897 Danubites nivalis DIENER, p. 51, pl. 15, figs 17-19.

1909 Xenodiscus nivalis - KRAFFT \& DIENER, p. 102, pl. 24, figs 1-3, 5; pl. 25, fig. 5.

1922 Xenodiscus nivalis - WeLTER, p. 107, pl. 5, figs 19, 20.

1922 Xenodiscus molengraaffi WeLTER, p. 108, pl. 4, figs 10-13.

1934 Anakashmirites nivalis - SPATH, p. 237, pl. 12, fig. 4a-e.

v 2012b Kashmirites cf. nivalis - BRÜHWILER \& BUCHER, p. 25, fig. 19AA-AH.

v 2012c Kashmirites nivalis - BRÜHWILER et al., p. 130, fig. 13I-R.

Occurrence: Kashmirites fauna.

Measurements: See Text-fig. 7. Estimated maximal size: $\sim 7 \mathrm{~cm}$.

Description: Very evolute, serpenticonic shell with convex flanks and slightly compressed whorls. Venter arched with rounded shoulders. Umbilicus wide, with low, inclined umbilical wall and rounded shoulders. Ornamentation consists of distant folds-like ribs that may cross the venter on the outer whorl of a few specimens. Ribs become finer and denser at maturity. Suture line ceratitic with relatively deep lobes; first lateral saddle very slightly phylloid.

Discussion: This species differs from K. armatus by its more compressed whorls and blunt, thicker ribs. Kashmirites kapila exhibits a sharper and denser ribbing.

Genus Preflorianites SPATH, 1930

Type species: Danubites strongi HYATT \& SMITH, 1905

\section{Preflorianites radians CHAO, 1959}

(Plate 2, Fig. V)

1922 Xenodiscus bittneri - WeLTER, p. 106, pl. 4, figs 8, 9.

1959 Preflorianites radians CHAO, p. 196, pl. 3, figs 6-8.

? 1968 Preflorianites cf. radians - ZAKHAROV, p. 137, pl. 27, figs 5, 6.

v 2008 Pseudoceltites? angustecostatus - BRAYARD \& BUCHER, p. 18, pl. 3, figs 1-7.

v 2012a Preflorianites radians - BRÜHWILER \& BUCHER, p. 15, pl. 1, figs 8, 9; pl. 2, figs1-7.

v 2012c Preflorianites cf. radians - BRÜHWILER et al., p. 132, fig. 13A-E.

2014 Preflorianites radians - SHIGETA \& NGUYEN, p. 66, figs 46, 47.

2018 Preflorianites cf. radians - JENKS \& BRAYARD, p. 15, figs 11, 12.

Occurrence: Owenites fauna. One single specimen.

Measurements: not available.

Description: Evolute shell with a compressed whorl section. Venter rounded with rounded shoulders forming elliptical whorl section. Large, shallow umbilicus with a steeply inclined wall and rounded shoulders. Ornamentation consists of regularly spaced, strong, slightly rursiradiate ribs fading out towards ventral shoulders. Suture line not available in our material.

Discussion: The reader is referred to BRAYARD et al. (2013), JATTIOT et al. (2017) and JENKS \& BRAYARD (2018).

Type species: Celtites multiplicatus WAAGEN, 1895

Genus Pseudoceltites HYATT, 1900

Pseudoceltites multiplicatus (WAAGEN, 1895)

(Plate 3, Figs A-AB, Plate 4, Figs A-O)

1895 Celtites multiplicatus WAAGEN, p. 78, pl. 7, fig. 2a-c.

1895 Celtites dimorphus WAAGEN, p. 80, pl. 7, fig. 5a-c.

1922 Kashmirites cf. subarmatus - WeLTER, p. 121, pl. 10, figs 6-8. 
1922 Kashmirites subrobustus WeLTER, p. 121, pl. 9, figs 13-15.

Kashhmirites robustus WELTER, p. 122, pl. 9, figs 7-8.

1922 Kashmirites evolutus WELTER, p. 124, pl. 10, figs 1-5.

1922 Kashmirites acutangulatus WELTER, p. 125, pl. 9, figs 9-12.

1976 Pseudoceltites multiplicatus - WANG \& HE, p. 289, pl. 6, figs 7-11.

? $1976 \quad$ Eukashmirites cf. blaschkei - WANG \& HE, p. 290, pl. 6, fig. 12.

? 1976 Eukashmirites cf. subarmatus - WANG \& HE, p. 291, pl. 6, figs 13, 14.

v 2010b Pseudoceltites multiplicatus - BRÜHWILER et al., p. 409, fig. 5 (1-7).

v 2012b Pseudoceltites multiplicatus - BRÜHWILER \& BUCHER, p. 27, fig. 21A-AC.

v 2012c Pseudoceltites multiplicatus - BRÜHWILER et al., p. 128, fig. 11A-Z.

v 2012c ?Pseudoceltites sp. indet. - BRÜHWILER et al., p. 130, fig. 11AA-AE.

Occurrence: Owenites fauna. In association with Nyalamites angustecostatus (see Plate 3, Fig. W).

Measurements: See Text-fig. 8. Estimated maximal size: $\sim 7 \mathrm{~cm}$.

Description: Moderately evolute to evolute shell, with a subquadratic to subrectangular whorl section. Flanks flat, converging very weakly. Venter broad and subtabulate, slightly arched with narrowly rounded shoulders. Umbilicus with a high vertical wall and marked, abruptly rounded shoulders. Great intraspecific variation in ornamentation, varying among specimens as well as on the same specimen from strong, distant radial ribs to fine, more closely spaced and slightly sinuous ribs. Remarkably, one specimen (Plate 3, Figs T-V) tends to develop umbilical tubercles. Ribs usually fade out on ventral shoulders, but occasionally cross the venter as faint ridges or folds; and tend to become finer and denser on flanks at mature stages. Suture line not available in our material.

Discussion: This species shows a very high morphological and ornamental variation. For instance, most of the specimens exhibit a subquadratic whorl section, but compressed variants with a subrectangular and narrower venter do exist, such as the holotype and some specimens from Timor (Plate 4, Figs A-O). 'Kashmirites' acutangulatus erected by WELTER (1922) also corresponds to these compressed variants of $P$. multiplicatus. Furthermore, our abundant and well-preserved material clearly shows that the three species K. subrobustus, K. robustus and K. evolutus erected by WELTER (1922) belong to the genus Pseudoceltites and merely represent variants of a single species: P. multiplicatus. Likewise, specimens described as $K$. cf. subarmatus by WELTER (1922) fall within the intraspecific variation of $P$. multiplicatus.

Pseudoceltites densistriatus (WELTER, 1922)

(Plate 4, Figs P-AJ)

1922 Kashmirites densistriatus WeLTER, p. 123, pl. 10, figs 9-16.

Occurrence: Owenites fauna.

Measurements: See Text-fig. 9. Estimated maximal size: $\sim 4.5 \mathrm{~cm}$.

Description: Moderately evolute to evolute shell, with a subquadratic to subrectangular whorl section. Flanks flat, converging very weakly. Venter broad and subtabulate, slightly arched with narrowly rounded shoulders. Umbilicus with a high vertical wall and marked, abruptly rounded shoulders. Ornamentation consists of very fine and very dense ribs that often cross the venter as faint ridges. Suture line not available in our material.

Discussion: Pseudoceltites densistriatus differs from the type species, especially on inner whorls, by its very dense and very fine ribbing. This type of ornamentation might fall within the intraspecific variation of $P$. multiplicatus. However, this hypothesis must remain uncorroborated in the absence of stratigraphical control and intermediate morphologies.

Genus Nyalamites BRÜHWILER, BUCHER \& GOUDEMAND, 2010b

Type species: Xenodiscus angustecostatus WELTER, 1922

Nyalamites angustecostatus (WELTER, 1922)

(Plate 5, Figs A-AE)

? 1895 Celtites acuteplicatus WAAGEN, 1895, p. 82, pl. 7a, figs 5-7.

1922 Xenodiscus angustecostatus WELTER, p. 110, pl. 4, figs 14-17.

1922 Xenodiscus oyensi WeLTER, p.111, pl. 5, figs 1, 2, 17.

1968 Anakashmirites angustecostatus - KUMMEL \& ERBEN, p. 128, pl. 19, figs 1-8.

1973 Anakashmirites angustecostatus - COLLIGNON, p. 144, pl. 5, figs 7-8.

1973 Anakashmirites oyensi-Collignon, p. 146, pl. 5, figs 9, 10.

1976 Pseudoceltites angustecostatus - WANG \& HE, p. 289, pl. 6, figs 3-6. 
v 2010b Nyalamites angustecostatus - BRÜHWILER et al. p. 411, fig. 7 (3-5).

v 2012a Nyalamites angustecostatus - BRÜHWILER \& BUCHER, p. 14, pl. 1, figs 3-6.

v 2012b Nyalamites angustecostatus - BRÜHWILER \& BUCHER, p. 29, fig. 2lAG-BB.

v 2012c Nyalamites angustecostatus - BRÜHWILER et al., p. 132, fig. 13S-AA.

Occurrence: Owenites fauna. In association with Pseudoceltites multiplicatus and Truempyceras pluriformis.

Measurements: See Text-fig. 10. Estimated maximal size: $~ 5.5 \mathrm{~cm}$.

Description: Very evolute shell with slightly convex, sub-parallel flanks. Venter subtabulate with narrowly rounded shoulders to slightly arched with rounded shoulders on largest specimens. Umbilicus shallow and wide with inclined wall and rounded shoulders. Ornamentation consists of regularly spaced, strong, sharp, radial ribs that fade out on ventral shoulders. This species exhibits some variation in ribbing density. Suture line not available in our material.

Discussion: This species marks the late middle Smithian in South Tibet, Pakistan and Spiti (Nyalamites angustecostatus beds, BRÜHWILER et al., 2010b, 2012b, c; Fig. 3). It also occurs in the Owenites koeneni fauna of Oman (BRÜHWILER et al., 2012a).

Type species: Hanielites elegans WELTER, 1922

\section{Genus Hanielites WELTER, 1922}

Hanielites elegans WELTER, 1922

(Plate 5, Figs AF-AK)

\begin{tabular}{|c|c|c|c|}
\hline & & 1922 & Hanielites elegans WELTER, p. 145, pl. 14, figs 7-11. \\
\hline & & 1934 & Hanielites elegans - SPATH, p. 243, fig. 82a-e. \\
\hline ? & & 1959 & Hanielites evolutus СНАО, p. 280, pl. 37, figs 8-12. \\
\hline ? & & 1959 & Hanielites elegans var. involutus СНАО, p. 281, pl. 37, figs 4-6. \\
\hline ? & & 1959 & Hanielites rotulus СНАО, p. 281, pl. 37, figs 12-15. \\
\hline ? & & 1959 & Owenites kwangsiensis CHAO, p. 250, pl. 22, figs 1, 2, 5, 6. \\
\hline ? & $\mathrm{V}$ & 2008 & Hanielites elegans BRAYARD \& BUCHER, p. 19, pl. 4, figs 1-5. \\
\hline & $\mathrm{V}$ & 2012c & Hanielites elegans BRÜHWILER et al., p. 132, fig. 14J-L. \\
\hline
\end{tabular}

Occurrence: Owenites fauna.

Measurements: See Text-fig. 11. Estimated maximal size: $2.5 \mathrm{~cm}$.

Description: Small, moderately involute shell with flat, parallel flanks. Venter subangular, with a low but distinct keel bearing a spiral strigation. Umbilicus moderately shallow with low, vertical wall and slightly rounded shoulders. Ornamentation is variocostate, consisting of distinct ribs becoming stronger at lower flank and stopping at ventral shoulders. Suture line not available in our material.

Discussion: Our larger specimen is identical to the holotype from Timor (WELTER 1922). Conversely, the morphology of specimens from China and Spiti (BRAYARD \& BUCHER 2008; BRÜHWILER et al. 2012c) is somewhat distant from that of the holotype. Indeed, they are significantly more evolute, they do not show a well-expressed keel, and their ribs are thinner and more closely spaced.

Due to the scarcity of the material from Timor, whether these specimens from China and Spiti represent another species or variants of $H$. elegans cannot be determined.

\section{Hanielites gracilus BRAYARD \& BUCHER, 2008}

$$
\text { (Plate 5, Figs AL-AV) }
$$

v 2008 Hanielites gracilus BRAYARD \& BUCHER, p. 20, pl. 4, figs 6-8.

Occurrence: Owenites fauna.

Measurements: See Text-fig. 12. Estimated maximal size: $~ 3.5 \mathrm{~cm}$.

Description: Small, moderately involute, compressed shell with flat, parallel flanks. Angular venter bearing a distinct keel and with rounded ventral shoulders. Umbilicus moderately shallow with low, vertical wall and slightly rounded shoulders. Ornamentation consists of thin prorsiradiate plications, projecting forward onto venter and terminating at the keel. Suture line not available in our material.

Discussion: This species mainly differs from the type species by its more compressed whorls and weaker, denser ornamentation.

\section{Kashmiritidae gen. et sp. indet.}

(Plate 15, Figs I-K)

Occurrence: Kashmirites fauna.

Measurements: See Table 1. Estimated maximal size: $\sim 10 \mathrm{~cm}$. 
Description: Relatively large, very slightly compressed shell with flat, parallel flanks forming a subrectangular whorl section. Venter broadly arched with indistinct Umbilicus wide and moderately shallow. Umbilical wall steep on inner whorls, becoming more inclined on outer whorl; umbilical shoulders marked but rounded. Ornamentation of the flanks consists of distant, fold-like ribs becoming denser and finer on second half of the outer whorl. Vague strigation visible on inner whorls. Suture line not available in our material.

Discussion: Coiling invites comparison with kashmiritids, especially with Kashmirites guangxiense BRAYARD \& BUCHER (2008). However, typical representatives of the family Kashmiritidae differ by their more evolute, serpenticonic coiling and lower whorls forming a subquadratic whorl section.

\section{Superfamily Meekocerataceae WAAGEN, 1895 \\ Family Proptychitidae WAAGEN, 1895 \\ Genus Roopnarinites n. gen.}

Type species: Roopnarinites n. gen. paucesculptatum (WELTER, 1922)

Etymology: Named after Peter Roopnarine.

Included species: Type species only.

Diagnosis: Thick, somewhat globose Proptychitidae with broad, rounded venter and suture with four slightly phylloid saddles.

Discussion: This genus is only tentatively assigned to the family Proptychitidae based on its suture line vaguely resembling that of Pseudaspidites, i.e., with phylloid saddles, strongly indented lobes, and second and third saddles markedly curved towards the umbilicus.

Roopnarinites n. gen. paucesculptatum (WELTER, 1922)

(Plate 6, Figs A-V)

1922 Meekoceras paucesculptatum WeLTER, p. 128, pl. 11, figs 16, 17; text-fig. 12.

Occurrence: Owenites fauna.

Measurements: See Text-fig. 13. Estimated maximal size: $\sim 3 \mathrm{~cm}$.

Description: Involute, slightly compressed shell with convex flanks. Whorl thickness and coiling somewhat variable. Venter rounded with rounded shoulders. Umbilicus with nearly perpendicular wall and rounded shoulders. On well-preserved shell, very feeble radial folds visible on the flanks. Suture line with four slightly phylloid saddles, strongly indented lobes, and second and third saddles markedly curved towards the umbilicus.

Discussion: The Oman specimen described as Pseudaspidites sp. indet. by BRÜHWILER \& BUCHER (2012a) is morphologically identical to one of our specimens (Plate 6, Figs G-I) but differs by its suture line with three saddles only, very close to that of typical Pseudaspidites. The American species Paranannites aspenensis HYATT \& SMITH, 1905 is very similar in shape but strongly differs by its simple suture line, with two broad lateral saddles.

Genus Tulongites BRÜHWILER, BUCHER \& GOUDEMAND, 2010b

Type species: Tulongites xiaoqiaoi BRÜHWILER et al., 2010b

?Tulongites sp. indet.

(Plate 6, Figs AA-AG)

Occurrence: Owenites fauna.

Measurements: See Table 1. Estimated maximal size: $3 \mathrm{~cm}$.

Description: Involute, platyconic shell with slightly convex flanks. Venter rounded with rounded shoulders. Umbilicus small with vertical wall and abruptly rounded shoulders. Ornamentation not preserved on our specimens. Suture line poorly preserved, with slightly phylloid first lateral saddle.

Discussion: The scarcity and the imperfect preservation of our material hinder a more precise assignment. However, those specimens seem morphologically rather similar to Tulongites xiaoqiaoi BRÜHWILER et al., 2010b, although they differ by having a slightly different suture line with broader saddles.

\section{Proptychitidae gen. et sp. indet.}

(Plate 6, Figs W-Z)

? V 2012b Proptychitidae gen. et sp. indet. A BRÜHWILER \& BUCHER, p. 53, fig. 37C-H.

Occurrence: Owenites fauna. One single specimen.

Measurements: See Table 1. Estimated maximal size: $\sim 2.5 \mathrm{~cm}$. 
Description: Involute, platyconic shell with slightly convex flanks. Venter slightly rounded with rounded shoulders. Umbilicus with moderately high, perpendicular wall and narrowly rounded shoulders. Surface smooth. Simple suture line, but incomplete and very poorly preserved.

Discussion: This taxon is somewhat similar to Pseudaspidites, but differs by its simpler suture line. Specimens described as Proptychitidae gen. et sp. indet. A by BRÜHWILER \& BUCHER (2012b) may represent the same taxon.

Genus Paraspidites SpATH, 1934

Type species: Aspidites superbus mut. praecursor FRECH, 1905

Discussion: As suggested by TOZER (1981), BRÜHWILER \& BUCHER (2012b) included this genus in the family Proptychitidae. Although supported by the suture line and the shape of the umbilicus, this assignment remains questionable as Paraspidites differs from other members of that family by its acutely keeled or bicarinate venter.

\section{Paraspidites bicarinatus n. sp.}

(Plate 6, Figs AH-AT)

Etymology: Named for its bicarinate venter.

Holotype: Specimen PIMUZ 37001 (Plate 6, Figs AN-AP).

Occurrence: Kashmirites fauna.

Measurements: See Text-fig. 14. Estimated maximal size: $\sim 6 \mathrm{~cm}$.

Diagnosis: Relatively evolute Paraspidites with thick whorls, a high umbilical wall and a distinctive very narrow bicarinate venter.

Description: Moderately involute, compressed shell with distinctive very narrow bicarinate venter. Maximum whorl width at umbilical margin. Umbilicus with high wall (overhanging on inner whorls of holotype; Plate 6, Fig. AN) and angular shoulders. Surface smooth except for extremely delicate strigation and weak folds. Suture line similar to that of Paraspidites obesus BRÜHWILER \& BUCHER, 2012b, i.e., with first lateral saddle long, narrow and slightly phylloid, second saddle broad and slightly asymmetrical, and auxiliary series with a well-individualized, small fourth saddle.

Discussion: This species is very similar to Paraspidites obesus that only differs by its acutely keeled venter.

\section{Family Galfettitidae BRÜHWILER \& BUCHER, 2012a}

Genus Galfettites BRAYARD \& BUCHER, 2008

Type species: Galfettites simplicitatis BRAYARD \& BUCHER, 2008

Galfettites simplicitatis BRAYARD \& BUCHER, 2008

$$
\text { (Plate 7, Figs A-I) }
$$

v 2008 Galfettites simplicitatis BRAYARD \& BUCHER, p. 48, pl. 21, figs 1, 2.

v 2012a Galfettites simplicitatis - BRÜHWILER \& BUCHER, p. 26, pl. 15, figs 1-4; pl. 16, fig. 1.

Occurrence: Owenites fauna. One specimen in association with Nyalamites angustecostatus.

Measurements: See Text-fig. 15. Estimated maximal size: $\sim 13.5 \mathrm{~cm}$.

Description: Evolute, very compressed shell with a very narrow tabulate venter and angular ventral shoulders. Flat, parallel flanks for about two thirds of flank, then gradually converging towards venter. Umbilicus shallow and wide with low, steeply inclined wall and rounded shoulders. Surface smooth except for dense, delicate folds. Suture line not available on our material.

Discussion: Galfettites omani BRÜHWILER \& BUCHER, 2012a is very similar to G. simplicitatis but differs by its shallower umbilicus and its distant folds on outer whorl. "Meekoceras" wanneri and "Meekoceras" hanieli erected by WeLTER (1922) from the "Meekoceras-Kalke" of Timor are very similar in shape to representatives of the genus Galfettites. However, suture line of "Meekoceras" wanneri is unknown and suture line of "Meekoceras" hanieli appears much simpler. Furthermore, the "Meekoceras-Kalke" is assumed to be of early Smithian age, since it is placed stratigraphically below the "Owenites-Kalke" according to WELTER (1922: 92). Therefore, these two species may rather belong to the family Flemingitidae (Rohillites?).

\section{Galfettites omani BRÜHWILER \& BUCHER, 2012a}

(Plate 7, Figs J-M) 
v 2012c Galfettites omani - BRÜHWILER et al., p. 137, fig. 17A-AD.

Occurrence: Anasibirites fauna.

Measurements: See Table 1. Estimated maximal size: $\sim 8 \mathrm{~cm}$.

Description: Moderately evolute and very compressed shell with a very narrow tabulate venter and angular ventral shoulders. Flat, parallel flanks for about two thirds of flank, then gradually converging towards venter. Umbilicus wide and very shallow with very low wall and rounded shoulders. Surface smooth except for vague, distant, radial folds on outer whorl. Suture line incomplete, but typical of the genus, i.e., with second lateral saddle with a distinctly trigonal tip and third saddle slightly curved towards the umbilicus.

Discussion: All previous specimens described as G. omani are older (middle Smithian; see BRÜHWILER et al. 2012a, c). Nevertheless, our specimens display all diagnostic features of this species and no paleontological condensation was evidenced in the Anasibirites blocks (see JATTIOT et al. 2015). Therefore, we here report the youngest occurrence of the genus Galfettites, from the late Smithian of Timor.

Genus Paranorites WAAGEN, 1895

Type species: Paranorites ambiensis WAAGEN, 1895

Paranorites cf. ambiensis WAAGEN, 1895

(Plate 7, Figs N-V)

1895 Paranorites ambiensis WAAGEN, p. 158, pl. 22, fig. la-d.

p 1895 Koninckites volutus WAAGEN, p. 268, pl. 28, fig. 1 only.

v 2012b Paranorites ambiensis - BRÜHWILER \& BUCHER, p. 64, figs 42A, 46A-I, 47A-J, 48A-F.

Occurrence: Kashmirites fauna.

Measurements: See Text-fig. 16. Estimated maximal size: $~ 3.5 \mathrm{~cm}$.

Description: Moderately involute, compressed shell with slightly convex, convergent flanks. Sligthly egressive coiling. Venter tabulate with angular shoulders. Umbilicus with high, vertical wall and marked, slightly rounded shoulders. Ornamentation consists of distant, vague folds fading out towards venter. Spiral lines visible near venter only. Suture line not available in our material.

Discussion: In the absence of suture line, the assignment of our specimens to Paranorites ambiensis is tentative only.

Genus Vercherites BRÜHWILER, WARE, BuCHER, KRYSTYN \& GOUdEMAND, 2010c

Type species: Koninckites vercherei WAAGEN, 1895

Vercherites cf. vercherei (WAAGEN, 1895)

(Plate 7, Figs W-AB)

1895 Koninckites vercherei WAAGEN, p. 268, pl. 30, fig. la-c.

v 2012b Vercherites vercherei - BRÜHWILER \& BUCHER, p. 64, figs 40A-M, 41A-N, 42I-L.

Occurrence: Kashmirites fauna.

Measurements: See Text-fig. 17. Estimated maximal size: $\sim 4 \mathrm{~cm}$.

Description: Moderately involute, compressed shell with subparallel flanks. Slightly egressive coiling. Venter tabulate with angular shoulders. Specimen PIMUZ 37011 (Pl. 7, Figs W-Y) is probably pathological as it shows a tabulate venter that becomes narrowly rounded on the outer whorl. Umbilicus with high, vertical wall and marked, slightly rounded shoulders. Ornamentation consists of dense, very weak folds and biconcave growth lines. Suture line not available in our material.

Discussion: Given the absence of suture line, the assignment of our specimens to $V$. vercherei is tentative only. Vercherites cf. vercherei mainly differs from $P$. cf. ambiensis by its earlier umbilical egression and flatter flanks.

Genus Urdyceras BRAYARD \& BUCHER, 2008

Type species: Urdyceras insolitus BRAYARD \& BUCHER, 2008

Urdyceras tulongensis BRÜHWILER, BUCHER \& GOUDEMAND, 2010b

(Plate 7, Figs AC-AQ)

v 2010b Urdyceras tulongensis BRÜHWILER et al., p. 416, fig. 10 (5-11).

v 2012c Urdyceras tulongensis - BRÜHWILER et al., p. 139, fig. 17AH-BF.

Occurrence: Owenites fauna.

Measurements: See Text-fig. 18. Estimated maximal size: $\sim 4 \mathrm{~cm}$. 
Description: Compressed and moderately involute to moderately evolute shell. Flanks convex and convergent. Venter tabulate with very angular shoulders. Umbilicus with steeply inclined wall and marked, slightly rounded shoulders. Ornamentation on flanks consists of low radial, slightly sinuous folds. Suture line not available in our material.

Discussion: According to BRÜHWILER et al. (2010b), the slightly older type species Urdyceras insolitus BRAYARD \& BUCHER, 2008 from the Flemingites rursiradiatus beds (late early Smithian) of South China differs by its thicker whorls and broader venter. However, based upon examination of the type material of the two species, we assert that $U$. insolitus does not exhibit a broader venter than $U$. tulongensis. Furthermore, several specimens assigned to U. tulongensis from Timor (this work, Plate 7, Figs AL-AN) and Spiti (BRÜHWILER et al. 2012c: figs 17AU-AW) have relatively thick whorls, making greater thickness as a diagnostic character of $U$. insolitus very doubtful. It is therefore not excluded that $U$. tulongensis is a synonym of $U$. insolitus, but more material from China is needed to verify this hypothesis.

Genus Safraites BRÜHWILER \& BUCHER, 2012a

Type species: Safraites simplex BRÜHWILER \& BUCHER, 2012a

Safraites simplex BRÜHWILER \& BUCHER, 2012a

(Plate 7, Figs AR-AU)

v 2012a Safraites simplex BRÜHWILER \& BUCHER, p. 29, pl. 8, figs 5-10.

Occurrence: Owenites fauna.

Measurements: See Text-fig. 19. Estimated maximal size: $\sim 2.5 \mathrm{~cm}$.

Description: Small, involute and compressed shell with subparallel flanks. Venter tabulate with angular shoulders. Umbilicus with very low, vertical wall and angular shoulders. Surface smooth. Suture line not available in our material.

Discussion: This species was originally described from the Nammalites pilatoides fauna of Oman (BRÜHWILER et al. 2012a).

Type species: Ceratites flemingianus DE KONINCK 1863

Family Flemingitidae HyATT, 1900

Genus Flemingites WAAGEN, 1895

Flemingites flemingianus (DE KONINCK, 1863)

(Plate 8, Figs A-C)

1863 Ceratites flemingianus DE KONINCK, p. 10, pl. 7, fig. 1.

1895 Flemingites flemingianus - WAAGEN, p. 199, pl. 12, fig. 1, pl. 13, fig. 1, pl. 14, fig. 1.

1895 Flemingites compressus WAAGEN, p. 202, pl. 15, fig. 1, pl. 16, fig. 1a-c.

1895 Flemingites trilobatus WAAGEN, p. 193, pl. 16, fig. 2a-b.

1922 Flemingites griesbachiformis WELTER, p. 113, pl. 8. figs 1, 2.

1933 Flemingites compressus - CollignON, p. 170, pl. 3, fig. 1, la.

1933 Flemingites flemingi madagascariensis Collignon, p. 173, pl. 5, fig. 1.

1933 Flemingites griesbachi - CollignON, p. 176, pl. 4, fig. 3, 3a; pl. 5, fig. 4; pl. 6, figs 1, 2.

v 2012b Flemingites flemingianus BRÜHWILER \& BUCHER, p. 66, figs 50A-K, 51A-G.

Occurrence: Kashmirites fauna. One single specimen.

Measurements: See Text-fig. 20. Estimated maximal size: $28 \mathrm{~cm}$.

Description: Very large shell with oval whorl section and egressive coiling. Inner whorls moderately evolute, outer whorls evolute. Venter rounded with indistinct shoulders. Umbilicus wide with rounded wall. Shell ornamented with coarse strigation and radial to slightly rursiradiate fold-like ribs. Ribs barely conspicuous on inner whorls, strongest at the beginning of the outer whorl and becoming finer and closely spaced on the last half of the outer whorl. Suture line not available in our material.

Discussion: This species is very similar to Flemingites pulcher WELTER, 1922 that mainly differ by its tabulate venter with abruptly rounded shoulders. Indeed, as stated by WAAGEN (1895) in his F. flemingianus description, 'on the whole the transverse section of the whorls is oval, well rounded everywhere’. We also assume a smaller size at maturity for F. pulcher.

Flemingites cf. planatus BRÜHWILER \& BUCHER, 2012b

(Plate 8, Figs D-F)

2012b Flemingites planatus BRÜHWILER \& BUCHER, p. 75, fig. 62A-K. 
Occurrence: Kashmirites fauna. One single specimen.

Measurements: See Text-fig. 21. Estimated maximal size: $\sim 8.5 \mathrm{~cm}$.

Description: Evolute shell with flat, subparallel flanks and maximum whorl width near mid-flank. Outer third of flanks convergent. Venter subtabulate with abruptly rounded shoulders. Umbilicus wide and shallow with low, nearly vertical wall amd rounded shoulders. Surface smooth except for very fine radial folds. Suture line not available in our material.

Discussion: In comparison with the holotype of Flemingites planatus, our specimen exhibits slightly lower whorls and lacks the strigation on outer flanks and venter, but is otherwise very similar.

Flemingites pulcher WELTER, 1922

(Plate 9, Figs A-G)

1922 Flemingites pulcher WELTER, p. 114, pl. 8, figs 3, 4; pl. 9, figs 1, 2.

Occurrence: Kashmirites fauna.

Measurements: See Text-fig. 22. Estimated maximal size: $13.5 \mathrm{~cm}$.

Description: Moderately evolute, compressed shell with convex flanks and maximum whorl width slightly above mid-flank. Venter tabulate with abruptly rounded shoulders. Umbilicus moderately deep with rounded wall. Shell ornamented with radial fold-type ribs on innermost whorls gradually passing to wide, low folds, as well as with strigation becoming gradually more conspicuous with growth. Suture line ceratitic with long. slightly phylloid saddles and strongly indented lobes.

Discussion: The Salt Range species Flemingites hofmanni BRÜHWILER et al., 2012b also exhibits a tabulate venter but differs by its lower, more compressed whorls and its suture line with much broader saddles.

\section{Flemingites lidakensis n. sp. \\ (Plate 10, Figs Q-V)}

Etymology: Named after Lidak locality in Timor.

Holotype: Specimen PIMUZ 37040 (Plate 10, Figs T-V).

Occurrence: Kashmirites fauna.

Measurements: See Table 1. Estimated maximal size: $~ 7 \mathrm{~cm}$.

Diagnosis: Serpenticone and very thick Flemingites with very low whorls.

Description: Evolute, serpenticonic, depressed shell with convex flanks and maximum whorl width slightly above mid-flank. Broadly rounded venter with indistinct shoulders. Umbilicus with high, nearly vertical wall and rounded shoulders. Surface smooth except for low constrictions and delicate strigation fading out at umbilical shoulders. Suture line not available in our material.

Discussion: This species significantly differs from other Flemingites species by its more evolute coiling and by its depressed whorls. Singularly, F. lidakensis n. sp. is similar in thickness and coiling to specimens from China assigned to F. flemingianus (BRAYARD \& BUCHER, 2008) that may actually represent variants of $F$. rursiradiatus according to BRÜHWILER \& BUCHER (2012b). However, these specimens display a conspicuous ribbing and a much stronger strigation.

Type species: Flemingites guyerdetiformis WELTER 1922

Genus Euflemingites SPATH, 1934

Euflemingites guyerdetiformis (WELTER, 1922)

(Plate 9, Figs H-M)

1922 Flemingites guyerdetiformis WeLTER, p. 117, pl. 6, figs 10-12.

1934 Euflemingites guyerdetiformis SPATH, p. 115, fig. 29.

Occurrence: Kashmirites fauna.

Measurements: See Table 1. Estimated maximal size: $\sim 5.5 \mathrm{~cm}$.

Description: Moderately involute, somewhat compressed shell with convex flanks and maximum whorl width near umbilical shoulders. Venter subtabulate with abruptly rounded shoulders. Umbilicus with moderately high, nearly vertical wall and rounded shoulders. Shell ornamented with a strigation fading out on upper flank. Suture line ceratitic with long, slightly phylloid saddles and strongly indented lobes.

Discussion: Contrary to SPATH's (1934) statement, the venter of Euflemingites guyerdetiformis is not arched but subtabulate. Euflemingites cirratus (WHITE, 1880) is mainly distinguished by its flat, parallel flanks and its much coarser strigation. Flemingites pulcher is similar in shape but differs by its more compressed whorls and the presence of radial ornamentation. 
Type species: Flemingites rohilla DIENER, 1897

\section{Rohillites rohilla (DIENER, 1897)}

(Plate 10, Figs A-P)

\begin{tabular}{|c|c|c|}
\hline & 1897 & tes rohilla DIENER, p. 93, pl. 18, figs 2-4; pl. 23, fig. 1. \\
\hline ? & 1922 & Flemingites cf. muthensis - WELTER, p. 113, pl. 6, figs 8, 9. \\
\hline $\mathrm{V}$ & 2008 & Rohillites sp. indet. - BRAYARD \& BUCHER, p. 47, pl. 19, fig. 7. \\
\hline & 2012a & hillites omanensis BRÜHWILER \& BUCHER, p. 23, pl. 13, fig \\
\hline
\end{tabular}

Occurrence: Kashmirites fauna.

Measurements: See Text-fig. 23. Estimated maximal size: $~ 8 \mathrm{~cm}$.

Description: Moderately evolute, compressed shell. Flanks parallel, although becoming markedly convergent on lower flanks. Venter tabulate with subangular to angular shoulders. Umbilicus with low wall and rounded umbilical shoulders. Ornamentation consists of vague radial folds and strigation usually restricted to lower flanks. Suture line ceratitic, with relatively strongly indented lobes, slightly phylloid saddles and asymmetrical third saddle.

Discussion: According to BRÜHWILER \& BUCHER (2012a), this species differs from Rohillites omanensis BRÜHWILER \& BUCHER, 2012a by being more evolute and by its narrower venter. However, our material from Timor allows us to assess the intraspecific variation of $R$. rohilla and shows that its venter width is variable (compare Plate 10, Figs A-C with Plate 10, Figs G-I), as well as its coiling (involute variant Plate 10, Fig. N). Thus, we here consider $R$. omanensis as a synonym of $R$. rohilla. The specimen from China described as Rohillites sp. indet. (BRAYARD \& BUCHER, 2008) might also belong to this species, but its poor preservation hinders a definitive assignment. Noteworthy, when shell is preserved in our material, the demarcation between the flat upper flanks and the markedly convergent lower flanks is very distinct, as the shell is thicker on this area. When specimens are preserved as internal molds, this demarcation is much less conspicuous.

R. pakistanensis BRÜHWILER \& BUCHER, 2012b, R. bruehwileri BRAYARD \& BUCHER, 2008 and $R$. sobolevi BRAYARD \& BUCHER, 2008 are mainly distinguished from $R$. rohilla by their stronger ornamentation, especially on outer whorls.

The specimen from Timor described as Flemingites cf. muthensis in WELTER (1922) is very similar to our material, although it appears to display stronger folds.

Genus Pseudoflemingites SPATH, 1930

Type species: Pseudoflemingites timorensis SPATH, 1930 (= Ophiceras nopscanum WeLTER, 1922, p. 104, pl. 4, figs 4, 5 only)

Pseudoflemingites timorensis SPATH, 1930

(Plate 9, Figs N-V)

p 1922 Ophiceras nopcsanum WeLTER, p. 104, pl. 4, figs 4, 5 only.

1930 Pseudoflemingites timorensis SPATH, p. 90.

1934 Pseudoflemingites timorensis - SPATH, p. 116, fig. 30.

non v 2012b Pseudoflemingites cf. timorensis - BRÜHWILER \& BUCHER, p. 78, fig. 61A-J.

Occurrence: Kashmirites fauna.

Measurements: See Text-fig. 24. Estimated maximal size: $\sim 7 \mathrm{~cm}$.

Description: Evolute, serpenticonic shell with convex flanks. Venter rounded with rounded ventral shoulders. Umbilicus wide and moderately shallow with nearly vertical wall and rounded shoulders. Ornamentation consists of extremely delicate strigation visible on a few specimens only, rursiradiate foldlike ribs, and ventro-lateral pairs of barely conspicuous and seldomly present nodes. Inner whorls nearly smooth. Suture line not available in our material.

Discussion: At comparable size, specimens from Pakistan described as Pseudoflemingites cf. timorensis (BRÜHWILER \& BUCHER, 2012b) are more involute and have slightly more compressed whorls. They also do not display rursiradiate ribs or pairs of ventro-lateral nodes.

Flemingites rursiradiatus CHAO, 1959 is very similar in shape, but is distinguished by its very distinct strigation, its stronger ornamentation, and by the absence of ventro-lateral nodes.

Type species: Aspidites meridianus involutus WELTER, 1922 
1922 Aspidites meridianus WeLTER, p. 132, pl. 12, figs 1-3.

1922 Aspidites meridianus involutus WELTER, p. 133, pl. 12, figs 4, 5.

1934 Subflemingites involutus - SPATH, p. 118, fig. 32.

non V 2012a Subflemingites involutus - BRÜHWILER \& BUCHER (= Anaxenaspis orientale), p. 23, pl. 13, figs 1-3. Occurrence: Kashmirites fauna.

Measurements: See Text-fig. 25. Estimated maximal size: $~ 7.5 \mathrm{~cm}$.

Description: Moderately involute, conpressed shell with slightly convex flanks and elliptical whorl section. Venter rounded with indistinct shoulders. Umbilicus with steeply inclined, low wall and abruptly rounded shoulders. Ornamentation consists of regular radial folds fading towards venter and more marked at mid-flank. Suture line too poorly preserved to be illustrated.

Discussion: Type specimens of Subflemingites involutus come from the early Smithian of Timor (“Ophiceras crassecostatum-Kalke”; WeLTER 1922). Specimens from Oman described as S. involutus (BRÜHWILER \& BUCHER, 2012a) are younger (middle Smithian, Nammalites pilatoides fauna) and do no not exhibit conspicuous folds. They are here reassigned to Anaxenaspis orientale (DIENER, 1895).

\section{Subflemingites bihatiense $\mathrm{n}$. sp.}

(Plate 11, Figs K-M)

? $\quad \mathrm{v}$ 2010b ?Leyeceras sp. indet. BRÜHWILER et al., p. 411, fig. 7 (8).

? $\quad$ v 2012a Leyeceras cf. rothi BRÜHWILER \& BUCHER, p. 18, pl. 5, figs 1-5; pl. 6, figs 1-3.

Etymology: Named after Bihati locality in Timor.

Holotype: Specimen PIMUZ 37046 (Plate 11, Fig. M).

Occurrence: Owenites fauna. In association with Nyalamites angustecostatus.

Measurements: See Table 1. Estimated maximal size: $\sim 6 \mathrm{~cm}$.

Diagnosis: Involute Subflemingites with weak, distant radial folds.

Description: Involute, conpressed shell with convex flanks and elliptical whorl section. Venter narrowly rounded, with indistinct shoulders. Umbilicus with steeply inclined, low wall and abruptly rounded shoulders. Ornamentation consists of weak radial folds fading towards venter and more marked at midflank. Extremely delicate strigation present at the beginning of the last whorl of the holotype. Suture line not available in our material.

Discussion: This species differs from the type species by its more involute coiling, its slightly higher whorl section and its more distant, weaker folds. Furthermore, the occurrence of $S$. bihatiense n. sp. is younger (middle Smithian). The species Leyeceras rothi BRAYARD \& BUCHER, 2008 strongly differs from Subflemingites bihatiense $\mathrm{n}$. sp. by its subtabulate venter, its thicker whorls and by the presence of radial lirae on flanks. Specimens described as Leyeceras cf. rothi by BRÜHWILER \& BUCHER (2012a) do not exhibit a subtabulate venter or lirae and are instead very similar to Subflemingites bihatiense n. sp. They very likely belong to this latter, but in the absence of suture line for Timor specimens, this hypothesis must remain uncorroborated.

\section{?Subflemingites sp. indet.}

(Plate 11, Figs N-Q)

Occurrence: Owenites fauna. One single specimen.

Measurements: See Table 1. Estimated maximal size: $~ 5 \mathrm{~cm}$.

Description: Involute shell with convex flanks. Venter rounded with indistinct shoulders. Funnel-like umbilicus, i.e., flanks gradually sloping until umbilical suture with no umbilical wall. Ornamentation consists of thick, very weak radial folds that cross the venter. Suture line very poorly preserved, with a wide first lateral lobe and a narrow second lateral lobe.

Discussion: The overall morphology and ornamentation consisting of folds only invites comparison with Subflemingites bihatiense n. sp. of the same age. However, it mainly differs by its more involute coiling and thicker whorls. The scarcity of the material and the lack of suture line information for our Subflemingites specimens preclude a generic assignment.

Type species: Xenaspis orientale DIENER, 1895 
Discussion: In shape, this genus is nearly identical to the American genus Anaflemingites KuMMEL \& STEELE (1962). However, Anaflemingites differs from Anaxenaspis by the presence of a strigation on the flanks. The type species Anaflemingites silberlingi KuMMEL \& STEELE (1962) is also distinguished from Anaxenaspis by a suture line with an extremely broad first lateral lobe and relatively narrow saddles, with the first lateral saddle being especially narrow.

\title{
Anaxenaspis orientale DIENER, 1895
}

(Plate 12, Figs A-P)

\author{
1895 Xenaspis orientale DIENER, 1895, p. 42, pl. 3, fig. 3. \\ 1922 Flemingites lidacensis WELTER, p. 115, pl. 7, figs 1-4. \\ 1922 Flemingites densistriatus WELTER, p. 116, pl. 6, figs 5-7. \\ ? $1959 \quad$ Flemingites cf. lidacensis - KUMMEL. \\ ? $\quad 1968 \quad$ Flemingites cf. lidacensis - KUMMEL \& ERBEN, p. 115, pl. 24, fig. 2. \\ ? $\quad 1973 \quad$ Flemingites lidacensis - Collignon, p. 9, pl. 2, figs 1-3. \\ 1978 Xenoceltites nammalensis GuEX, p. 112, pl. 6, figs 1, 2. \\ ? V 2008 ?Anaxenaspis sp. indet. - BRAYARD \& BUCHER, p. 49, pl. 23, fig. l. \\ v 2008 Anaflemingites hochulii BRAYARD \& BUCHER, p. 51, pl. 24, figs 3-6. \\ v 2012a Anaxenaspis cf. lidacensis - BRÜHWILER \& BUCHER, p. 22, plate 13, figs 9-11; plate 14, figs 1-3. \\ v 2012a Subflemingites involutus - BRÜHWILER \& BUCHER, p. 23, pl. 13, figs 1-3. \\ v 2012b Anaxenaspis nammalensis - BRÜHWILER \& BUCHER, p. 78, fig. 64A-V. \\ v 2012c ?Anaxenaspis sp. indet. - BRÜHWILER et al., p. 145, figs 22A-M, 23A-C.
}

Occurrence: Owenites fauna.

Measurements: See Text-fig. 26. Estimated maximal size: $~ 17 \mathrm{~cm}$.

Description: Large, compressed and evolute shell with elliptical whorl section and convex flanks. Venter narrowly rounded with indistinct or abruptly rounded shoulders. Umbilicus with steeply inclined wall and rounded shoulders. Ornamentation highly variable, from nearly smooth shell with faint folds only, to conspicuous radial fold-like ribs varying in strength and fading out towards venter. When present, ribbing gradually weakens at later stages. Slightly biconcave growth lines discernible on a few specimens. Suture line with strongly indented lobes and elongated, sometimes slightly phylloid saddles; but highly variable.

Discussion: BRÜHWILER \& BUCHER (2012a) assigned the Timor species "Flemingites" lidacensis (WELTER, 1922) to Anaxenaspis 'because it shows no significant differences with the type species Anaxenaspis orientale, except for its delicate strigation’. In our extensive material of Anaxenaspis ( 40 specimens), a thorough investigation of the astonishingly preserved shells led to the conclusion that there is no strigation whatsoever on the flanks. Extremely delicate spiral wrinkles are nevertheless sporadically visible on rare specimens. We assume that these wrinkles create the false impression of a strigation on WELTER's (1922) illustrations of the type specimens of A. lidacensis and A. densistriatus. Therefore, we here consider $A$. orientale and $A$. lidacensis as conspecific. Given the large intraspecific variation of $A$. orientale as evidenced in our material (Plate 12, Figs A-P), we also synonymize A. densistriatus with $A$. orientale.

According to BRÜHWILER \& BUCHER (2012b), the type species only differs from Anaxenaspis nammalensis (GUEX, 1978) from the Salt Range by its smoother inner whorls. However, our Timor material shows that the range of intraspecific variation of $A$. orientale includes specimens that can also display ornamented inner whorls as seen in A. nammalensis. This latter is therefore synonymized with $A$. orientale. Finally, a reinvestigation of the suture line of Anaflemingites hochulii BRAYARD \& BUCHER, 2008 type specimen revealed that it actually displays a broader second lateral saddle than what illustrated in BRAYARD \& BUCHER (2008). This revised feature and the absence of strigation are contradictory with what is seen in Anaflemingites. Therefore, this species is here transferred to A. orientale as it does not show any difference with our weakly ornamented variants.

Noteworthy, the vast range of intraspecific variation of $A$. orientale combined with the absence of stratigraphical control made assignments of some specimens to either A. orientale, A. compressus or Hochuliites retrocostatus BRÜHWILER et al., 2012c (see below) very difficult and tentative only.

Anaxenaspis compressus (BRÜHWILER et al., 2010b)

(Plate 13, Figs $\mathrm{H}-\mathrm{N}$ )

v 2010b ?Subflemingites compressus BRÜHWILER et al., p. 413, fig. 8 (1-6).

v 2012c ?Subflemingites compressus - BRÜHWILER et al., p. 145, fig. 23D-J.

Occurrence: Owenites fauna. One specimen in association with Pseudoceltites multiplicatus. 
Measurements: See Text-fig. 27. Estimated maximal size: $~ 7.5 \mathrm{~cm}$.

Description: Moderately evolute, compressed shell with slightly convex flanks and elliptical whorl section. Venter narrowly rounded with indistinct shoulders. Umbilicus with inclined wall and rounded shoulders. Ornamentation consists of vague folds. Very delicate strigation discernible on venter of one specimen (Plate 13, Fig. J). Suture line with strongly indented lobes and elongated, slightly phylloid saddles.

Discussion: Anaxenaspis compressus from South Tibet was originally tentatively assigned to the genus Subflemingites SPATH, 1934. However, this latter clearly differs by its umbilicus with steeply inclined, low wall and abruptly rounded shoulders. We here assign this species to the genus Anaxenaspis and, as a general rule, it differs from the type species by being more involute and more compressed. Some rare variants of $A$. orientale are as involute, but they are more strongly ornamented and thicker.

Hochuliites retrocostatus BRÜHWILER et al., 2012c differs from A. compressus by its simpler suture line, whose saddles are broad and nonphylloid; and by its much more conspicuous ornamentation.

Genus Baidites BRÜHWILER \& BUCHER, 2012a

Type species: Baidites hermanni BRÜHWILER \& BUCHER, 2012a

\section{Baidites tenue (WELTER, 1922)}

(Plate 14, Figs A-J)

1922 Ophiceras tenue WeLTER, p. 104, pl. 3, figs 1, 2.

? p 1922 Ophiceras nopcsanum WELTER, p. 104, pl. 4, figs 1-3 only.

non p 1922 Ophiceras nopcsanum WeLTER, p. 104, pl. 4, figs 4, 5 only (= Pseudoflemingites timorensis).

? 1922 Xenodiscus rotula - WELTER, p. 106, pl. 6, figs 3, 4.

Occurrence: Kashmirites fauna.

Measurements: See Text-fig. 28. Estimated maximal size: $\sim 8.5 \mathrm{~cm}$.

Description: Evolute, compressed shell. Relatively narrow, subtabulate to tabulate venter with abruptly rounded shoulders. Whorl shape constant throughout ontogeny, with slightly converging flanks from umbilical margin area towards venter. Umbilicus wide and relatively shallow. Umbilical wall steep on inner whorls, becoming more inclined on outer whorl; umbilical shoulder marked but rounded. Ornamentation of the flanks usually consists of low, distant radial folds. Suture line ceratitic with rather narrow, deep lobes.

Discussion: One specimen (V-346, Plate 14, Figs G-I) displays an unusually strong ornamentation consisting of dense, conspicuous folds but is otherwise morphologically identical to other specimens assigned to Baidites tenue. Baidites tenue and the type species share a narrow venter and compressed whorls. However, B. hermanni is distinguished by a singular ontogenetic change in whorl section, with flat flanks on inner whorls and outer whorls showing a demarcation between the inner two thirds and the outer third (see BRÜHWILER et al. 2012a, pl. 11, fig. 3). Furthermore, in comparison with B. tenue, the type species appears more evolute and exhibits a conspicuous ornamentation on outer whorls consisting of blunt ribs.

\section{Baidites crassecostatum (WELTER, 1922)}

(Plate 14, Figs K-Z)

1922 Ophiceras crassecostatum WeLTER, p. 103, pl. 2, figs 11-14; pl. 3, fig. 3.

? 1922 Xenodiscus rotula - WeLTER, p. 106, pl. 5, figs 8-10.

Occurrence: Kashmirites fauna.

Measurements: See Text-fig. 29. Estimated maximal size: $13.5 \mathrm{~cm}$.

Description: Large, evolute, somewhat compressed to depressed shell. Venter relatively broad and subtabulate to lowly arched on robust specimens, with abruptly rounded shoulders. Maximum whorl width at umbilical margin. Flanks distinctively converving towards venter from the umbilical margin. Umbilicus wide and moderately shallow. Umbilical wall steep with marked umbilical shoulders on inner whorls becoming rapidly more inclined with rounded umbical shoulders on outer whorl. Ornamentation of the flanks consists of blunt fold-like ribs that do not cross the venter. Ornamentation stronger on robust, more evolute variants. This type of covariation is well known as Buckman's first law of covariation (WESTERMANN 1966, HAMMER \& BUCHER 2005). Strength and spacing of ribs somewhat variable. Ribs gradually passing to closely spaced low folds on outer whorl eventually fading out at 
maturity. Growth lines replacing the ribs discernible at maturity. No strigation visible on our specimens. Suture line not available in our material.

Discussion: Two specimens (Plate 14, Figs K-P) are interpreted as more evolute and robust variants. Their greater whorl thickness results in the presence of a broadly arched venter instead of the usual subtabulate venter.

Baidites tenue mainly differs from $B$. crassecostatum by its narrower venter and more compressed whorl section. Alternatively, $B$. tenue could correspond to extreme compressed variants of $B$. crassecostatum. However, in the absence of stratigraphical control and of intermediate forms, it is safer to retain the two existing species.

The spiral strigation described by WELTER (1922) on one of the two type specimens was not observed on our specimens, despite an exceptional state of preservation of the shell.

Baidites obesus n. sp.

(Plate 15, Figs A-H)

? 1922 Ophiceras cf. gibbosum - WeLTER, p. 105, pl. 3, figs 8, 9; pl. 4, fig. 6, 7.

Etymology: The species name refers to its involute coiling.

Holotype: Specimen PIMUZ 37071 (Plate 15, Figs F-H).

Occurrence: Kashmirites fauna.

Measurements: See Text-fig. 30. Estimated maximal size: $~ 10 \mathrm{~cm}$.

Diagnosis: Involute Baidites with thick whorls.

Description: Relatively large, somewhat compressed shell. Venter subtabulate with marked but rounded shoulders. Maximum whorl width at umbilical margin. Flanks converging towards venter from the umbilical margin. Umbilicus deep and moderately wide. Umbilical wall steep on inner whorls, becoming more inclined on outer whorl; umbilical shoulders marked but rounded. Ornamentation of the flanks consists of low, broad folds gradually fading throughout ontogeny. Suggestion of strigation only locally visible. Slightly biconcave growth lines discernible at maturity. Suture line ceratitic with rather narrow, deep lobes, similar to that of $B$. tenue.

Discussion: This species clearly differs from Baidites crassecostatum and $B$. tenue by its higher whorls, more involute coiling and ornamentation characterized by low, broad folds.

\section{Family Dieneroceratidae KUMMEL, 1952}

Genus Dieneroceras SPATH, 1934

Type species: Ophiceras dieneri HYATT \& SMITH, 1905

Dieneroceras dieneri (HYATT \& SMITH, 1905)

(Plate 16, Figs A-R)

1905 Ophiceras dieneri HYATT \& SMITH, p. 118, pl. 8, figs 16-29.

? 1905 Xenaspsis marcoui HYATT \& SMITH, p. 116, pl. 7, figs 26-33.

1932 Ophiceras dieneri - SMITH, p. 48, pl. 8, figs 16-29.

? 1932 Xenodiscus (Xenaspsis) marcoui - SMITH, p. 47, pl. 7, figs 26-33.

1955 Ophiceras iwaiense SAKAGAMI, p. 135, pl. 1, figs 1-9.

1955 Ophiceras sp. - SAKAGAMI, p. 136, pl. 1, figs 10-11.

? $1959 \quad$ Kariceltites indicus JEANNET, p. XXX, pl. 7, figs 10-12; pl. 8, fig. 15.

1960 Dieneroceras iwaiense - KUMMEL \& SAKAGAMI, p. 4, pl. 1, figs 3-5; pl. 2, figs 7-9.

? 1961 Dieneroceras dieneri - KIPARISOVA, p. 47, pl. 9, fig. 2.

? 1961 Dieneroceras chaoi KIPARISOVA, p. 48, pl. 9, figs 3-6.

? 1961 Dieneroceras caucasicum Popov, p. 41, pl. 6, fig. 1.

? 1965 Dieneroceras cf. dieneri - KUENZI, p. 369, pl. 53, figs 13-18, text-figs 3, 4.

1968 Dieneroceras dieneri - NAKAZAWA \& BANDO, p. 93, pl. 4, figs 1-6.

1968 Dieneroceras aff. chaoi - NAKAZAWA \& BANDO, p. 95, pl. 4, figs 7, 8; pl. 5, fig. 1.

? 1973 Dieneroceras knechti-Collignon, p. 131, pl. 1, figs 2, 3.

? 1973 Dieneroceras chaoi - Collignon, p. 132, pl. 1, figs 6-8.

? 1995 Dieneroceras caucasicum - SHEVYREV, p. 25, pl. 1, figs 3-5.

? 1995 Dieneroceras magnum SHEVYREV, p. 26, pl. 1, fig. 6.

2010 Wyomingites arnoldi - STEPHEN et al, fig. 5c, d.

v 2012 Dieneroceras cf. dieneri - BRÜHWILER \& BUCHER, p. 20, pl. 8, figs 1-4; pl. 9, figs 1-7; pl. 10, figs 1-3.

v 2013 Dieneroceras dieneri-BRAYARD et al., p. 173, fig. 36a-s.

v 2017 Dieneroceras dieneri - JATTIOT et al., p. 19, pl. 5, figs A-S.

2018 Dieneroceras dieneri - JENKS \& BRAYARD, p. 38, fig. 32. 
Occurrence: Owenites fauna.

Measurements: See Text-fig. 31. Estimated maximal size: $~ 3.5 \mathrm{~cm}$.

Description: Serpenticonic, laterally compressed shell with a subtabulate to tabulate venter and a large umbilicus. Broadly convex flanks with maximum thickness near umbilicus, impartling a slightly ovoid whorl section. Inner whorls slightly more rounded than outer whorls. Umbilical wall steeply inclined with rounded shoulders, forming a shallow umbilicus. Surface smooth except for faintly sinuous growth lines and barely conspicuous folds on some juvenile specimens. Spiral strigation described by HyATT \& SMITH (1905) from type specimen not observed on our exceptionally well-preserved material. Suture line not available in our material.

Discussion: The reader is referred to BRAYARD et al. (2013) and JENKS \& BRAYARD (2018) for further details.

\section{Dieneroceras knechti (HYATT \& SMITH, 1905)}

(Plate 16, Figs S-V)

1905 Lecanites knechti HyATT \& SMITH, p. 138, pl. 9, figs 11-16.

1915 Proavites knechti - DIENER, p. 228.

1932 Lecanites (Paralecanites) knechti - SMITH, p. 41, 42, pl. 9, figs 11-16; p. 28, figs 1-7.

1934 “Lecanites” knechti - SPATH, p. 88, 93, 123, 134.

1962 Dieneroceras knechti - KUMMEL \& STEELE, p. 662, pl. 99, figs 14, 15.

v 2017 Dieneroceras knechti - JATTIOT et al., p. 21, pl. 5, figs T-AA.

2018 Dieneroceras knechti - JENKS \& BRAYARD, p. 41, fig. 36.

Occurrence: Owenites fauna.

Measurements: see Table 1. Estimated maximal size: $\sim 5 \mathrm{~cm}$.

Description: Serpenticonic, laterally compressed shell with rounded venter and broad umbilicus. Broadly convex flanks with maximum thickness near umbilicus, imparting a slightly ovoid whorl section. Inner whorls slightly more rounded than outer whorls. Umbilical wall steeply inclined with rounded shoulders forming a shallow umbilicus. Surface smooth except for faintly sinuous growth lines and delicate strigation on one specimen (Plate 16, Fig. S). Injury visible on same specimen as a scar on the outer whorl. Suture line not available in our material.

Discussion: Dieneroceras knechti is distinguished from $D$. dieneri by its rounded venter.

Dieneroceras cf. tientungense CHAO, 1959

(Plate 16, Figs W-AI)

1959 Dieneroceras tientungense CHAO, p. 192, pl. 2, figs 5-6, 8-10, 29.

1959 Dieneroceras? vermiforme CHAO, p. 192, pl. 2, figs 14-16, 28.

1959 Dieneroceras ovale CHAO, p. 192, pl. 2, figs 11-13.

v 2008 Dieneroceras tientungense - BRAYARD \& BUCHER, p. 40, pl. 15, figs 5-12.

v 2012c Dieneroceras cf. tientungense - BRÜHWILER et al., p. 139, fig. 17BG-BV.

Occurrence: Kashmirites fauna.

Measurements: See Text-fig. 32. Estimated maximal size: $\sim 6.5 \mathrm{~cm}$.

Description: Serpenticonic, evolute to very evolute shell with slightly convex flanks. Venter subtabulate to gently rounded with rounded shoulders. Umbilicus wide and shallow with rounded umbilical wall. Ornamentation consists of weak folds and minor contrictions. Suture line simple, typical of family, with narrow, relatively deep lobes; indentation of lobes poorly preserved.

Discussion: Most of our largest specimens (>20 mm) are more involute and show slightly higher whorls than typical representatives of Dieneroceras tientungense, making the taxonomical assignment uncertain. However, D. tientungense exhibits significant variation in whorl section (BRAYARD \& BUCHER 2008), and these specimens from Timor may fall within the range of its intraspecific variation.

Family Paranannitidae SPATH, 1930

Genus Owenites HYATT \& SMITH, 1905

Type species: Owenites koeneni HYATT \& SMITH, 1905

\section{Owenites koeneni HYATT \& SMITH, 1905}

$$
\text { (Plate 17, Figs AB-AW) }
$$


1932

1932

1934

1947

1955

1957

1959

1959

1959

1959

1959

1959

1960

1962

1962

1965

1966

1968

1968

1968

1973

1979

1981

1984

1984

1990

1995

? 2004

V 2008

V 2010b

V 2012

V 2012c

V 2013

2014

V 2017

2018

Owenites egrediens - SMITH, p. 100, pl. 52, figs 6-8.

Owenites zitteli SMITH, p. 101, pl. 52, figs 1-5.

Owenites koeneni - SPATH, p. 185, fig. 57.

Owenites aff. egrediens - KIPARISOVA, p. 139, pl. 32, figs 1-3.

Kingites shimizui SAKAGAMI, p. 138, pl. 2, figs 2a-c.

Owenites koeneni - KUMMEL in ARKELL et al., p. L138, figs 171-8a-b.

Owenites costatus CHAO, p. 249, pl. 22, figs 10-18, 22, 23, text-fig. 26c.

Owenites pakungensis CHAO, p. 248, pl. 21, figs 6-8.

Owenites pakungensis var. compressus CHAO, p. 248, pl. 21, figs 4, 5.

Pseudowenites oxynotus CHAO, p. 252, pl. 23, figs 1-16, text-figs 27a-d.

Owenites shimizui - KUMMEL, p. 430.

Owenites cf. koeneni - KUMMEL, p. 441, figs 2-4.

Owenites shimizui - KUMMEL \& SAKAGAMI, p. 6, pl. 2, figs 5, 6.

Owenites koeneni - KUMMEL \& STEELE, p. 674, pl. 101, figs 3-7.

Owenites koeneni - PoPOV, p. 44, pl. 6, fig. 6.

Owenites koeneni - KUENZI, p. 374, pl. 53, figs 1-6, text-figs 3d, 6.

Owenites koeneni - HADA, p. 112, pl. 4, figs 2-4.

Owenites koeneni - KUMMEL \& ERBEN, p. 121, figs 12; pl. 19, figs 10-15.

Owenites carinatus SHEVYREV, p. 189, pl. 16, fig. 1.

Owenites koeneni - ZAKHAROV, p. 94, pl. 18, figs 1-3.

Owenites koeneni - Collignon, p. 139, pl. 4, figs 2, 3.

Owenites koeneni - NiCHOLS \& SILBERLING, pl. 1, figs 17, 18.

Owenites koeneni - BANDO, p. 158, pl. 17, fig. 7.

Owenites carinatus - VU KHUC, p. 81, pl. 6, figs 1-4, text-fig. H16.

Pseudowenites oxynotus - Vu KHUC, p. 82, pl. 7, figs 3, 4.

Owenites koeneni - SHEVYREV, p. 118, pl. 1, fig. 5.

Owenites koeneni - SHEVYREV, p. 51, pl. 5, figs 1-3.

Owenites pakungensis - TONG et al., p. 199, pl. 2, figs 9-10, text-fig. 7.

Owenites koeneni - BRAYARD \& BUCHER, p. 67, pl. 36, figs 9-10, text-fig. 7.

Owenites koeneni - BRÜHWILER et al., p. 426, fig. 15(9).

Owenites koeneni - BRÜHWILER \& BUCHER, p. 43, pl. 25, figs 1-6.

Owenites koeneni - BRÜHWILER et al., p. 155, fig. 35AH-AJ.

Owenites koeneni - BRAYARD et al., p. 204, fig. 74.

Owenites koeneni - SHIGETA \& NGUYEN, p. 126, figs 89-96

Owenites koeneni - JATTIOT et al., p. 38, pl. 17, figs K-AD.

Owenites koeneni - JENKS \& BRAYARD, p. 96, figs 92, 93A-C'.

Occurrence: Owenites fauna.

Measurements: See Text-fig. 33. Estimated maximal size: $\sim 7 \mathrm{~cm}$.

Description: Fairly small, compressed, involute shell characterized by an inflated lenticular whorl section with maximum width at umbilical shoulder. Venter subangular to angular that may resemble a keel on some specimens. Umbilicus characterized by large variation in width, from occluded to fairly narrow with low, gently inclined wall and broadly rounded shoulders. Most of the largest shells exhibit some degree of egressive coiling of the ultimate whorl.

Surface smooth except for dense, prorsiradiate growth lines that project forward high on flank and also tend to form barely perceptible folds bordered by minute constrictions in rare instances. Suture line ceratitic with several divided umbilical saddles.

Discussion: As shown by JENKS \& BRAYARD (2018), this species exhibits an extremely wide range of intraspecific variation in umbilicus width, especially in its mature form. However, among specimens superior to $3 \mathrm{~cm}$ in diameter illustrated in JENKS \& BRAYARD (2018), none shows an occluded umbilicus. On the contrary, some of our largest Timor specimens (diameter between 3 and $4.5 \mathrm{~cm}$ ) clearly exhibit an occluded umbilicus. These specimens might demonstrate an even wider intraspecific variability of umbilicus shape in $O$. koeneni. Alternatively, they might be representatives of a new species with an occluded umbilicus at all growth stages. More Timor material is needed to decipher this taxonomic conundrum.

Owenites egrediens WELTER, 1922

(Plate 18, Figs A-AD)

1922 Owenites egrediens WELTER, p. 151, pl. 14, figs 22-26.

1934 Owenites egrediens - SPATH, p. 186, figs 56, 57d-f. 
Occurrence: Owenites fauna.

Measurements: See Text-fig. 34. Estimated maximal size: $\sim 5.5 \mathrm{~cm}$.

Description: Involute shell with an inflated, lenticular whorl section, very convergent flanks and egressive coiling. Subangular to angular venter that may resemble a keel on some specimens. Maximum thickness on the umbilical margin. Funnel-shaped umbilicus with marked umbilical shoulders and a high, inclined wall. Surface smooth except for growth lines and very weak folds in rare instances. Injury visible on specimen PIMUZ 37106 (Plate 18, Figs D, E) as deep scar all along the outer whorl, resulting in the disappearance of the angular venter ('ornamental compensation'; see GuEX 1968). Suture line not available in our material.

Discussion: Owenites egrediens WELTER, 1922 is mainly distinguished from the type species by its diagnostic funnel-shaped umbilicus with marked umbilical shoulders, its very converging flanks and its greater thickness at mature stages $(\mathrm{D}>40 \mathrm{~mm}$ ). Although hardly distinguishable, juvenile stages of $O$. egrediens differ from those of $O$. koeneni by their slightly greater thickness.

\title{
Owenites simplex WELTER, 1922
}

(Plate 19, Figs A-AM)

\author{
1922 Owenites simplex WELTER, p. 153, pl. 15, figs 1-8. \\ 1934 Parowenites simplex - SPATH, p. 187, fig. 58. \\ 1959 Owenites kwangsiensis CHAO, p. 250, pl. 22: 1-6, text-fig. 26b. \\ 1959 Owenites plicatus CHAO, p. 251, pl. 22: 19-21, 24-25, text-fig. 26e. \\ 1968a Owenites simplex - KUMMEL, p. 2, pl. 1, figs 1-9. \\ 1968 Owenites simplex - KUMMEL \& ERBEN, p. 122, fig. 12k, n, o. \\ v 2008 Owenites simplex - BRAYARD \& BUCHER, p. 69, pl. 35, figs 20-22; text-fig. 59. \\ v 2010b Owenites simplex - BRÜHWILER et al., p. 427, pl. 35, fig. 15 (10-12). \\ v 2012a Owenites simplex - BRÜHWILER \& BUCHER, p. 46, pl. 24, figs 10-14. \\ non v 2012c Owenites cf. simplex - BRÜHWILER et al., p. 158, figs 35Y-AC.
}

Occurrence: Owenites fauna.

Measurements: See Text-fig. 35. Estimated maximal size: $\sim 4 \mathrm{~cm}$.

Description: Moderately involute and somewhat compressed shell with subparallel flanks. Subangular to angular venter that may resemble a keel on some specimens. Moderately deep umbilicus with a low, inclined wall and rounded shoulders. Ornamentation consists of conspicuous, prorsiradiate, sigmoidal fold-like ribs becoming denser and weaker at maturity. Suture line not available in our material.

Discussion: Owenites simplex is distinguished from other Owenites species by its more evolute coiling at all ontogenetic stages and by its lower whorls. Owenites koeneni and O. egrediens also do not show a conspicuous ribbing. Specimen PIMUZ 37124 (Plate 19, Figs W-Z) and specimens from China (BRAYARD \& BUCHER 2008) are weakly ornamented variants.

Owenites sp. indet.

(Plate 17, Figs A-AA)

Occurrence: Owenites fauna.

Measurements: See Text-fig. 36. Estimated maximal size: $\sim 2.5 \mathrm{~cm}$.

Description: Small, very involute and inflated shell. Venter subangular to narrowly rounded. Flanks convex from the occluded umbilicus. Maximum thickness near the umbilicus. Surface smooth, except for growth lines when and very weak constrictions.

Discussion: These small-sized specimens of Owenites are hardly assignable to any species. All could be juveniles of $O$. koeneni, although thickest specimens might as well be juveniles of $O$. egrediens. If we admit some variability, the whole group also morphologically corresponds to the species $O$. carpenteri SMith, 1932, abundantly mentioned in the Tethys (South China, BRAYARD \& BuCHER 2008; South Tibet, BRÜHWILER et al. 2010b; Oman, BRÜHWILER et al. 2012a; and Spiti, BRÜHWILER et al. 2012c), by having a rounded venter and an occluded umbilicus. However, the validity of this species is highly questionable, as most of specimens figured under that name fall well within the intraspecific variation of $O$. koeneni (see JENKS \& BRAYARD 2018, for a thorough discussion on O. carpenteri legitimacy).

\section{Steckites brevus WELTER, 1922}

(Plate 20, Figs A-AU)

2012c Steckites brevus BRÜHWILER et al., p. 161, figs 35AV-BC.

2018 Steckites cf. brevus - JENKS \& BRAYARD, p. 100, fig. 93G'-M'. 
Occurrence: Owenites fauna.

Measurements: See Text-fig. 37. Estimated maximal size: $\sim 3.5 \mathrm{~cm}$.

Description: Involute, slightly compressed shell with subparallel flanks. Venter subangular with indistinct shoulders. Umbilicus with inclined wall and rounded shoulders. Surface smooth except for prorsiradiate, sinuous and weal plications that cross the venter. Suture line ceratitic, with three lateral saddles and a very short auxiliary series.

Discussion: This taxon is very similar to Owenites, but this latter displays a suture line with several wellindividualized auxiliary saddles (BRÜHWILER et al. 2012c) and a more angular venter. Steckites brevus also differs from $O$. egrediens and $O$. koeneni by its different whorl section (subparallel flanks). Owenites simplex shares a somewhat similar whorl section, but it is much more evolute and it bears a much stronger ornamentation.

Genus Omanites BRÜHWILER et al. 2012a

Type species: Omanites musjahensis BRÜHWILER et al. 2012a

?Omanites sp. indet.

(Plate 16, Figs AJ-AK)

Occurrence: Owenites fauna. One single specimen.

Measurements: See Table 1. Estimated maximal size: $\sim 2.5 \mathrm{~cm}$.

Description: Small, depressed and evolute shell. Venter rounded without shoulders. Umbilicus deep, with high, vertical wall and rounded shoulders. Surface smooth. Suture line not available in our material.

Discussion: This specimen is somewhat similar to Omanites musjahensis BRÜHWILER et al., 2012a that differs by being more involute at comparable size.

\section{Family Melagathiceratidae WAAGEN, 1895}

Genus Juvenites SMITH, 1927

Type species: Juvenites kraffti SMITH, 1927

Juvenites spathi (FREBOLD, 1930)

(Plate 21, Figs A-AB)

? 1922 Nannites cf. heberti - WeLTER, p. 100, pl. 2, figs 8-10.

? 1922 Nannites cf. hindostanus - WeLTER, p. 102, pl. 2, figs 5-7.

1930 Prosphingites spathi FrEBOLD, p. 20, pl. 4, figs 2, 3, 3a.

1934 Prosphingites spathi - SPATH, p. 195, pl. 13, figs 1, 2.

p ? 1959 Prosphingites kwangsianus CHAO, p. 296, pl. 28, figs 17, 18.

p ? 1959 Prosphingites sinensis CHAO, p. 297, pl. 27, figs 14-17, text-fig. 40a.

? $1961 \quad$ Prosphingites spathi - TOZER, p. 58, pl. 13, figs 1, 2.

? $\quad 1962$ “Prosphingites” slossi KuMMEL \& STEELE, p. 683, pl. 101, figs 8-17.

? $1982 \quad$ Prosphingites spathi - KORCHINSKAYA, pl. 5, fig. 2.

? $\quad 1994 \quad$ Paranannites spathi - TOZER, p. 77, pl. 36, figs 1, 2.

v 2008 Paranannites spathi - BRAYARD \& BUCHER, p. 63, pl. 35, figs 10-19.

v 2010b Paranannites spathi - BRÜHWILER et al., p. 426, fig. 16(1, 2).

v 2012a Juvenites spathi - BRÜHWILER \& BUCHER, p. 38, pl. 22, figs 12-17.

v 2012c Paranannites sp. indet. BRÜHWILER et al., p. 155, figs 35A-X.

v 2012c Juvenites cf. spathi - BRÜHWILER et al., p. 161, figs 37A-O.

v ? 2013 Juvenites aff. spathi - BRAYARD et al., p. 166, fig. 27a-c.

2014 Paranannites sinensis - SHIGETA \& NGUYEN, p. 120, figs 85-87.

v 2017 Juvenites spathi - JATTIOT et al., p. 17, pl. 3, figs AF-AW.

2018 Juvenites spathi - JENKS \& BRAYARD, p. 107, figs 98, 99.

Occurrence: Owenites fauna.

Measurements: See Text-fig. 38. Estimated maximal size: $\sim 5.5 \mathrm{~cm}$.

Description: Globose and moderately evolute shell. Venter arched, or triangular in rare instances only (Plate 21, Figs A-C). Flanks gradually converging towards the venter from bluntly angular umbilical shoulder. Umbilicus deep with high, perpendicular wall (crateriform umbilicus). Ornamentation consists of prorsiradiate constrictions, becoming denser at maturity. Suture line not available in our material. Specimen PIMUZ 37150 (Plate 21, Figs M, N) is a complete, mature individual.

Discussion: Our material reveals that large-size specimens do not necessarily display a triangular whorl section, contrary to as commonly stated (e.g., BRAYARD et al. 2013). Consequently, the marked crateriform umbilicus with bluntly angular umbilical shoulders is the most diagnostic trait of Juvenites 
spathi (see discussion in JENKS \& BRAYARD 2018). Specimens assigned to Paranannites sp. indet in BRÜHWILER et al. (2012c) are only slightly more compressed and involute than typical representatives of $J$. spathi and therefore very likely fall within the intraspecific variation of this species.

Juvenites septentrionalis SMITH, 1932

(Plate 22, Figs A-Q)

1932 Juvenites septentrionalis SMITH, p. 110, pl. 31, figs 31-40.

1932 Juvenites sanctorum SMITH, p. 110, pl. 31, figs 22-30.

1978 Juvenites sp. indet. GuEX, pl. 5, fig. 3.

v 2008 Juvenites procurvus BRAYARD \& BUCHER, p. 32, pl. 22, figs 6-12.

v 2008 Juvenites cf. kraffti BRAYARD \& BUCHER, p. 32, pl. 9, figs 20-23.

v 2012a Juvenites procurvus - BRÜHWILER \& BUCHER, p. 41, pl. 22, figs 10-11.

v 2012b Juvenites cf. kraffti - BRÜHWILER \& BUCHER, p. 105, fig. 89BB-BF.

v 2012c Juvenites procurvus - BRÜHWILER et al., p. 163, fig. 37AK-AP.

2018 Juvenites septentrionalis - JENKS \& BRAYARD, p. 103, figs 95, 96A-H.

Occurrence: Owenites fauna.

Measurements: See Text-fig. 39. Estimated maximal size: $\sim 3.5 \mathrm{~cm}$.

Description: Small, moderately evolute shell with an arched venter and flanks convergent from umbilical shoulders to rounded venter (without distinct ventral shoulders). Moderately deep umbilicus with relatively high, steeply inclined wall and somewhat abruptly rounded shoulders. Ornamentation consists of strong, slightly forward projected constrictions crossing the venter with equal intensity. Density and intensity of constrictions highly variable among specimens. Suture line not available in our material.

Discussion: Our Timor specimens tend to confirm that Juvenites thermarum is more involute and more depressed than $J$. septentrionalis (Text-fig. 39), as stated by BRAYARD et al. (2013: 165). Furthermore, $J$. septentrionalis specimens as gathered in our synonymy list usually differ from published specimens of $J$. thermarum by their stronger and/or more closely spaced constrictions. Nevertheless, it is not excluded that $J$. thermarum and $J$. septentrionalis might alternatively represent a single species with a large intraspecific variation (see detailed discussion in JENKS \& BRAYARD 2018).

Family Inyoitidae SPATH, 1934

Genus Subinyoites SPATH, 1930

Type species: Inyoites kashmiricus DIENER, 1913

Subinyoites cf. punjabiensis BRÜHWILER \& BUCHER, 2012b

(Plate 22, Figs U-X)

2012b Subinyoites punjabiensis BRÜHWILER \& BUCHER, p. 107, fig. 93S-AA.

Occurrence: Owenites fauna. One single specimen.

Measurements: See Table 1. Estimated maximal size: $\sim 4.5 \mathrm{~cm}$.

Description: Moderately involute shell with an elliptical whorl section. Egressive coiling. Venter narrowly rounded with indistinct shoulders. Umbilicus relatively deep, with inclined wall and rounded shoulders. Surface smooth except for slightly biconcave growth lines and faint folds. Suture line ceratitic with relatively narrow lateral lobe and second lateral saddle slighty tapered. Indentations of lobes poorly preserved.

Discussion: In shape, this specimen is identical to the holotype of $S$. punjabiensis. However, this species was first described from a younger stratigraphic unit (late Smithian, Wasatchites distractus beds, BRÜHWILER et al., 2012b). Furthermore, the suture line of our Timor specimen has a slightly narrower lateral lobe (Plate 22, Fig. U). Therefore, the species assignment must remain uncertain.

Genus Subvishnuites SPATH, 1930

Type species: Vishnuites spec. WELTER, 1922 (= Subvishnuites welteri sp. nov. SPATH, 1930)

Subvishnuites welteri SPATH, 1930

(Plate 22, Figs Y-AS)

1922 Vishnuites spec. - WELTER, p. 137, pl. 13, figs 3-5.

1930 Subvishnuites welteri SPATH, p. 30, p. 90.

1934 Subvishnuites welteri - SPATH, p. 117, fig. 31.

1959 Subvishnuites welteri - KUMMEL, p. 443, fig. 7.

v 2012a Subvishnuites welteri - BRÜHWILER \& BUCHER, p. 36, pl. 21, figs 9-13. 
v 2017 Subvishnuites welteri - JATTIOT et al., p. 25, pl. 8, figs O-T.

Occurrence: Owenites fauna. In association with Nyalamites angustecostatus.

Measurements: See Text-fig. 40. Estimated maximal size: $\sim 6.5 \mathrm{~cm}$.

Description: Compressed, evolute shell. Convex flanks, subparallel on the inner half and strongly convergent towards the venter on the outer half. Whorl shape highly variable at juvenile stages. Venter narrowly rounded or almost acute, except for individuals with depressed juvenile stages that instead bear a rounded venter (Plate 22, Figs AK-AM and see cross-section of holotype in WeLTER 1922, pl. 13, fig. 4). Umbilicus wide and moderately deep with relatively high and steeply inclined wall, and rounded shoulders. Ornamentation consisting of closely and regularly spaced, weak folds. Suture line too poorly preserved to be illustrated.

Discussion: Inyoites stokesi KUMMEL \& STEELE, 1962 differs from S. welteri by its keel, more compressed shell and conspicuous ribbing.

\section{Subvishnuites cf. posterus BRÜHWILER et al., 2012c}

(Plate 22, Figs AT, AU)

v 2012a Subvishnuites sp. indet. - BRÜHWILER \& BUCHER, p. 36, pl. 21, fig. 14.

v 2012c Subvishnuites posterus BRÜHWILER et al., p. 163, fig. 37AQ-BK.

Occurrence: Anasibirites fauna. One single specimen.

Measurements: See Text-fig. 41. Estimated maximal size: $~ 5.5 \mathrm{~cm}$.

Description: Moderately evolute, compressed shell. Flanks subparallel on the upper half and strongly converging on the lower half. Venter narrowly rounded. Umbilicus wide and shallow with rounded umbilical wall. Ornamentation not preserved. Suture line not available in our material.

Discussion: This specimen is morphologically very similar to typical representatives of Subvishnuites posterus. However, its poor preservation precludes a definitive specific assignment.

Genus Hochuliites BRÜHWILER et al., 2012c

Type species: Hochuliites retrocostatus BRÜHWILER et al., 2012c

Hochuliites retrocostatus BRÜHWILER et al., 2012c

(Plate 13, Figs A-G)

v 2012c Hochuliites retrocostatus BRÜHWILER et al., p. 107, fig. 39Q-AA.

Occurrence: Owenites fauna.

Measurements: See Text-fig. 42. Estimated maximal size: $10 \mathrm{~cm}$.

Description: Evolute, compressed shell with an elliptical whorl section. Venter narrowly rounded with indistinct shoulders. Umbilicus with steeply inclined wall and rounded shoulders. Ornamentation consists of rursiradiate folds on upper flanks that fade out below mid-flank. Growth lines biconcave. Suture line ceratitic with relatively narrow lateral lobe and low, broad saddles.

Discussion: Hochuliites retrocostatus differs from Anaxenaspis orientale by its more compressed whorl section, its denser ornamentation, especially on innermost whorls, and its simpler suture line, whose saddles are low and broad.

\section{Family Arctoceratidae ARTHABER, 1911}

Genus Truempyceras BRÜHWILER \& BUCHER, 2012b

Type species: Anasibirites pluriformis GUEX, 1978

Discussion: According to BRÜHWILER \& BUCHER (2012b, p. 89), 'Truempyceras differs from Brayardites by its less convergent flanks, its more tabulate venter with more pronounced shoulders and its ornamentation, which tends to develop a ventro-lateral tuberculation'. However, Timor material shows that some specimens of Brayardites also exhibit a ventro-lateral tuberculation (Plate 24, Figs A, B, R-T).

Truempyceras pluriformis (GUEX, 1978)

(Plate 23, Figs A-Z)

\footnotetext{
? $1895 \quad$ Ceratites normalis WAAGEN, p. 38, pl. 6, fig. 2.

? $\quad 1911 \quad$ Pronorites osmanicus ARTHABER, p. 205, pl. 17, fig. 10.

1922 Pronorites spec. ind. ex aff. arbani v. Arth. - WELTER, p. 95, pl. 1, fig. 9.

p $\quad 1978 \quad$ Anasibirites pluriformis GUEX, p. 107, pl. 3, figs 7-9; pl. 4, figs 1-2, 4, 7-8 only; pl. 5, figs 6-7.

1985 Anasibirites sp. PAKISTANI-JAPANESE RESEARCH GROUP, pl. 14, fig. 1a-b.

v 2010b 'Anasibirites’pluriformis - BRÜHWILER et al., p. 423, fig. 5(8).

2012b Truempyceras pluriformis - BRÜHWILER \& BUCHER, p. 89, figs 72P-U, 73A-N.
} 
? V V 2012b ?Pseudoceltites cf. normalis - BRÜHWILER \& BUCHER, p. 27, fig. 21AD-AF.

Occurrence: Owenites fauna. Often in association with Nyalamites angustecostatus.

Measurements: See Text-fig. 43. Estimated maximal size: $\sim 7.5 \mathrm{~cm}$.

Description: Moderately involute shell with flat, slightly convergent flanks. Distinct egressive coiling. Venter subtabulate to slightly arched with narrow, rounded shoulders. Umbilicus with a high, vertical wall (somewhat overhanging on some specimens) and abruptly rounded shoulders. Ornamentation of variable strength, conforming to the Buckman's first law of covariation (WESTERMANN 1966), and consisting of radial, slightly biconcave ribs that form a tuberculation on ventral shoulders. Strongest ribs may cross the venter. Robust variants also exhibit elongated umbilical tubercles. Suture line ceratitic with relatively deep lobes and tapered saddles.

Discussion: Truempyceras compressum BRÜHWILER et al., 2012c is distinguished by a more compressed whorl section, a narrower venter with angular shoulders, and a weaker ornamentation. 'Ceratites normalis' (WAAGEN 1895) and the single fragmentary specimen assigned to ?Pseudoceltites normalis in BRÜHWILER \& BUCHER (2012b) might correspond to the most compressed and most involute variants of T. pluriformis showing a weaker ornamentation with slightly denser row of marginal tubercles, as illustrated by some of our specimens (e.g., Pl. 23, Figs J-L, P-R). According to BRÜHWILER \& BUCHER (2012b), the holotype of 'Ceratites' normalis is supposedly much older (lower Smithian), whereas ?Pseudoceltites cf. normalis is of the same age than our material.

Truempyceras compressum BRÜHWILER et al., 2012c

(Plate 23, Figs AD-AT)

? 1922 Pronorites arbanus v. Arth. - WelteR, p. 94, pl. 1, fig. 10-14.

2012c Truempyceras compressum BRÜHWILER et al., p. 148, fig. 29A-AA.

Occurrence: Owenites fauna.

Measurements: See Text-fig. 44. Estimated maximal size: $~ 11 \mathrm{~cm}$.

Description: Moderately involute to moderately evolute, compressed shell with flat, slightly convergent flanks. Distinct egressive coiling. Venter subtabulate with angular to slightly rounded shoulders. Umbilicus with a high, vertical wall (somewhat overhanging on some specimens) and abruptly rounded shoulders. Ornamentation consists of weak, slightly biconcave ribs or almost inexistent on involute juvenile specimens. Strongest ribs may cross the venter. Suture line ceratitic with relatively deep lobes.

Discussion: The reader is referred to T. pluriformis discussion.

\section{Truempyceras cf. compressum BRÜHWILER et al., 2012c}

(Plate 23, Figs AA-AC)

2012c Truempyceras compressum BRÜHWILER et al., p. 148, fig. 29A-AA.

Occurrence: Owenites fauna. One single specimen.

Measurements: See Table 1. Estimated maximal size: $~ 5.5 \mathrm{~cm}$.

Description: Moderately involute, compressed shell with flat, slightly convergent flanks. Distinct egressive coiling. Venter tabulate with angular shoulders. Umbilicus with a high, vertical wall and abruptly rounded shoulders. Ornamentation only consists of very weak folds. Suture line not available.

Discussion: This specimen differs from typical representatives of Truempyceras compressum by its narrower, tabulate venter with angular shoulders and by the near absence of ornamentation.

Genus Brayardites BRÜHWILER et al., 2010b

Type species: Brayardites crassus BRÜHWILER et al., 2010b

Discussion: When erecting the genus Brayardites, BRÜHWILER et al. (2010b) did not include specimens described as Meekoceras malayicum by WELTER (1922). Yet, this species definitely belongs to this genus. The genus Brayardites shows a remarkably vast morphological and ornamental variability, making species taxonomy very difficult to establish. For this reason, and in the absence of any stratigraphical control, we opted for a typological approach and here retain all existing species.

Brayardites compressus BRÜHWILER et al., 2010b

(Plate 24, Figs A-T)

v 2010b Brayardites compressus BRÜHWILER et al., p. 419, fig. 13 (1-6).

v 2012b Brayardites compressus - BRÜHWILER \& BUCHER, p. 82, figs 70A-AC, ?AD-AF.

v 2012c Brayardites compressus - BRÜHWILER et al., p. 145, figs 25A-O, 26A.

Occurrence: Owenites fauna. One specimen in association with Nammalites cf. pilatoides. 
Measurements: See Text-fig. 45. Estimated maximal size: $~ 10 \mathrm{~cm}$.

Description: Moderately evolute, compressed shell with flat, converging flanks. Maximum whorl width near umbilical shoulder. Venter subtabulate with rounded shoulders. Umbilicus with very high, vertical wall (overhanging in rare instances) and rounded shoulders. Ornamentation consists of prorsiradiate, biconcave fold-like ribs that develop strong tubercles near umbilicus and fade out towards mid-flank. Thick folds may cross the venter, and rare specimens (Plate 24, Figs A, B, R-T) bear tubercles on ventral shoulders, reminiscent of those present in Truempyceras. Growth lines biconcave. Suture line ceratitic with relatively deep lobes.

Discussion: Upon comparison between type specimens of Brayardites malayicum (WELTER, 1922) and $B$. compressus, this latter differs by its strong, distant umbilical tubercles and its conspicuous ornamentation on inner whorls. B. malayicum also shows a more rounded venter. Noteworthy, some of our $B$. compressus specimens are somewhat morphologically intermediate between the two species as they bear less conspicuous tubercles (e.g., Pl. 24, figs C-E, L-N). Wether or not these two species represent endmember variants of a single, highly variable species cannot be determined in the absence of any stratigraphical control.

\section{Brayardites malayicum (WELTER, 1922)}

(Plate 25, Figs A-S)

1922 Meekoceras malayicum WeLTER, p. 127, pl. 11, figs 6-9.

v p ? 2012c Brayardites compressus - BRÜHWILER et al., p. 145, fig. 26A only.

Occurrence: Owenites fauna. One specimen in association with Hanielites gracilus.

Measurements: See Text-fig. 46. Estimated maximal size: $10 \mathrm{~cm}$.

Description: Moderately evolute, compressed shell with flat, converging flanks. Maximum whorl width near umbilical shoulder. Subtabulate to rounded venter, with rounded shoulders. Umbilicus with very high, vertical wall (overhanging in rare instances) and rounded shoulders. Ornamentation consists of dense prorsiradiate biconcave fold-like ribs becoming stronger near umbilical shoulders but without forming true tubercles. Suture line not available in our material.

Discussion: The reader is referred to Brayardites compressus discussion. Specimen illustrated as $B$. compressus in BRÜHWILER et al. (2012c, fig. 26A) might actually be a representative of B. malayicum.

\section{Brayardites cf. malayicum (WELTER, 1922)}

(Plate 25, Figs T-AA)

1922 Meekoceras malayicum - WELTER, p. 127, pl. 11, figs 6-9.

v p ? 2012c Brayardites compressus - BRÜHWILER et al., p. 145, fig. 26A only.

Occurrence: Owenites fauna. One specimen in association with Hanielites gracilus.

Measurements: see See Text-fig. 46. Estimated maximal size: $\sim 8.5 \mathrm{~cm}$.

Description: Moderately evolute shell with thick whorls and converging flanks. Maximum whorl width near umbilical shoulder. Venter broadly arched with rounded shoulders, and rounded shoulders. Umbilicus with very high, vertical wall (overhanging in rare instances) and rounded shoulders. Ornamentation consists of prorsiradiate ribs becoming stronger near umbilical shoulders, then resembling elongated tubercles. Ribs fade out towards mid-flank. Suture line not available in our material.

Discussion: These specimens differ from Brayardites malayicum by their wider and arched venter, their stronger ribbing, and their thicker whorls. They might represent robust end-member variants of $B$. malayicum. They are also very similar to the type species $B$. crassus that only differs by its more depressed whorls and by being more evolute. Brayardites cf. malayicum is somewhat morphologically intermediate between $B$. malayicum and B. crassus.

Genus Nammalites BRÜHWILER, BUCHER \& GOUDEMAND, 2010b

Type species: Kazakhstanites pilatoides GUEX, 1978

?Nammalites cf. pilatoides (GUEX, 1978)

(Plate 26, Figs A-I)

1909 Meekoceras sp. ind. aff. pilato - KRAFFT \& DIENER, p. 42, pl. 28, fig. 2a-c.

1968b Subvishnuites cf. enveris - KUMMEL, p. 491, pl. 1, figs 8-9.

1968b Wasatchites sp. indet. - KUMMEL, p. 500, pl. 3, figs 10-11.

1968 Eoptychites sp. indet. - KuMMEL \& ERBEN, p. 120, pl. 22, figs 10-11.

1978 Kazakhstanites pilatoides GuEX, p. 109, pl. 6, figs 5, 6, 16. 
? $1978 \quad$ Kazakhstanites pilatoides GUEX, p. 109, pl. 8, fig. 6.

p 1978 Anasibirites pluriformis GUEX, pl. 4, fig. 3 only.

V 2010b Nammalites pilatoides - BRÜHWILER et al. p. 416, fig. 15(6-8).

V 2012a Nammalites pilatoides - BRÜHWILER \& BUCHER, p. 31, pl. 18, figs 1-7.

v 2012b Nammalites pilatoides - BRÜHWILER \& BUCHER, p. 85, fig. 72A-O.

v 2012c Nammalites pilatoides - BRÜHWILER et al., p. 146, figs 26B-Y, 27A-D.

Occurrence: Owenites fauna. One specimen in association with Brayardites compressus.

Measurements: See Text-fig. 47. Estimated maximal size: $\sim 4.5 \mathrm{~cm}$.

Description: Moderately involute shell with convex, convergent flanks. Maximum whorl width at umbilical border. Venter broadly rounded to subtabulate with rounded shoulders. Umbilicus with high, vertical wall and abruptly rounded shoulders. Ornamentation consists of distant, rursiradiate ribs that tend to develop elongated bullae near the umbilicus and then fade out towards the venter. Suture line ceratitic with deep lobes.

Discussion: According to BRÜHWILER et al. (2010b), the slightly older genus Brayardites differs essentially by its prorsiradiate ribbing and stronger tubercles. However, given the absence of stratigraphical control and the high intraspecific variability observed in Brayardites (see below), our specimens are only tentatively assigned to Nammalites pilatoides based on their rursiradiate ribbing.

Genus Churkites OKunEVA, 1990

Type species: Churkites egregius ZHARNIKOVA \& OKUNEVA in OKUNEVA, 1990

Churkites warei n. sp.

(Plate 26, Figs J-O)

Etymology: Named after David Ware (Berlin).

Holotype: Specimen PIMUZ 37213 (Plate 26, Figs M-O).

Occurrence: Owenites fauna. In association with Nyalamites angustecostatus.

Measurements: See Table 1. Estimated maximal size: $7.5 \mathrm{~cm}$.

Diagnosis: Churkites with a conspicuous ribbing on inner whorls, gradually passing to vague umbilical tubercles throughout ontogeny.

Description: Moderately evolute with compressed and relatively high whorls. Egressive coiling at maturity. Narrowly rounded venter at juvenile stages, becoming acute at maturity. Gently convex flanks forming slightly ovoid whorl. Umbilical wall high and perpendicular with abruptly rounded shoulders. Ornamentation consists of marked fold-like ribs on inner whorls. Mature stages bear weak umbilical tubercles slightly extending on the flanks. Suture line not available in our material.

Discussion: This species is distinguished from Churkites noblei JENKS, 2007 mainly by its conspicuous ribbing on inner whorls (see JENKS 2007; JENKS et al. 2010; BRAYARD et al. 2013; JATTIOT et al. 2017; JENKS \& BRAYARD 2018). The close affinities of Churkites species between opposite sides of Panthalassa underline the potential long-distance faunal exchange that occurred during the Early Triassic (BRAYARD et al. 2009b; SHIGETA \& KUMAGAE 2015).

\section{Family Prionitidae HyATT, 1900}

Genus Prionites WAAGEN, 1895

Type species: Prionites tuberculatus WAAGEN, 1895

Prionites tuberculatus WAAGEN, 1895

(Plate 27, Figs A-R)

1895 Prionites tuberculatus WAAGEN, p. 58, pl. 5, fig. 2a-c.

1895 Prionites undatus WAAGEN, p. 59, pl. 5, fig. la-b.

1895 Prionites lingnatus WAAGEN, p. 61, pl. 6, fig. 3-5.

1922 Prionites laevis WeLTER, p. 134, pl. 12, figs 8-10.

1922 Prionites armatus WeLTER, p. 135, pl. 12, figs 11-13.

1922 Prionites elegans WeLTER, p. 136, pl. 12, figs 14-16.

v 2012b Prionites tuberculatus - BRÜHWILER \& BUCHER, p. 91, figs 75A-V, 76A-E.

Occurrence: Owenites fauna. Commonly in association with Nyalamites angustecostatus.

Measurements: See Text-fig. 48. Estimated maximal size: $\sim 9 \mathrm{~cm}$.

Description: Involute shell with egressive coiling at maturity. Maximum whorl width at upper third of flank. Venter tabulate with angular shoulders on inner whorls, subtabulate with rounded shoulders on outer whorls. Umbilicus deep and funnel-shaped with inclined wall and rounded shoulders. Inner whorls smooth or with strong tubercles on very depressed specimens (e.g., Plate 27, Figs J-L); outer whorls with 
distant bullae on inner flanks that develop into strong, broad tubercles. Growth lines biconcave. Suture line not available in our material.

Discussion: Although all juvenile specimens figured by BRÜHWILER et al. (2012b) have compressed whorls, suggesting that it is the typical juvenile morphology, specimen PIMUZ 37217 (Pl. 27. Figs J-L) shows that adult features (tubercules and great thickness, conforming to the Buckman's first law of covariation; WESTERMANN 1966) can occur earlier in ontogeny.

\section{Prionites involutus BRÜHWILER et al., 2010b}

(Plate 27, Figs S-Y)

v 2010b Prionites involutus BRÜHWILER et al., p. 419, fig. 14 (1-6).

Occurrence: Owenites fauna. In association with Nyalamites angustecostatus.

Measurements: See Text-fig. 49. Estimated maximal size: $\sim 7 \mathrm{~cm}$.

Description: Involute, compressed shell with slightly convex flanks. Egressive coiling at maturity. Maximum whorl width below mid-flank. Venter tabulate with angular shoulders, but subtabulate with abruptly rounded shoulders at maturity. Umbilicus narrow, deep and funnel-shaped with inclined wall and rounded shoulders. Surface smooth except for biconcave growth lines. Delicate spiral strigation on the venter of one specimen (Plate 27, Fig. U). Suture line ceratitic with broad saddles.

Discussion: Prionites involutus differs from $P$. tuberculatus by retaining a compressed whorl section and involute coiling throughout ontogeny.

Prionites nammalensis BRÜHWILER \& BUCHER, 2012b

(Plate 27, Figs Z-AB)

v 2012b Prionites nammalensis BRÜHWILER \& BUCHER, p. 93, fig. 76F-X.

Occurrence: Owenites fauna. One single specimen, in association with Nyalamites angustecostatus.

Measurements: See Text-fig. 50. Estimated maximal size: $\sim 7 \mathrm{~cm}$.

Description: Moderately involute, compressed shell with egressive coiling at maturity and convex, convergent flanks. Maximum whorl width at upper third of flank. Venter tabulate with angular shoulders, but subtabulate with abruptly rounded shoulders at maturity. Umbilicus funnel-shaped with inclined wall and rounded shoulders. Surface smooth except for biconcave growth lines. The low, prorsiradiate, distant wavy folds on lower flanks described by BRÜHWILER et al. (2012b) are not visible on our specimen. Suture line not available in our material.

Discussion: This species differs from Prionites tuberculatus by its narrower venter and its more compressed outer whorls. Furthermore, according to BRÜHWILER et al. (2012b), its suture line has deeper lobes. It is more evolute than P. involutus.

Type species: Stephanites superbus WAAGEN, 1895

\section{Stephanites superbus WAAGEN, 1895}

(Plate 27, Figs AC-AD)

1895 Stephanites suberbus WAAGEN, p. 101, pl. 2, fig. 2.

1895 Stephanites corona WAAGEN, p. 102, pl. 3, fig. l.

1905 Stephanites corona - FRECH, pl. 28, fig. 1.

v 2010b Stephanites superbus - BRÜHWILER et al., p. 423, fig. 14 (7-12).

v 2012b Stephanites superbus - BRÜHWILER \& BUCHER, p. 94, fig. 81 A-H.

v 2012c Stephanites superbus - BRÜHWILER et al., p. 152, fig. 31 P-S.

Occurrence: Owenites fauna. One single specimen, in association with Nyalamites angustecostatus.

Measurements: See Text-fig. 51. Estimated maximal size: $\sim 4.5 \mathrm{~cm}$.

Description: Moderately involute shell with convex, convergent flanks. Maximum whorl width slightly below mid-flank. Venter broadly rounded with rounded shoulders. Umbilicus very deep with wellrounded, inclined wall without distinct shoulders. Ornamentation consists of strong, distant tubercles on flanks, coinciding with maximum whorl width. Tubercles are elongated dorso-ventrally. Suture line not available in our material.

Discussion: The reader is referred to BRÜHWILER et al. (2012b). 
1895 Acrochordiceras distractum WAAGEN, p. 94, pl. 3, fig. 4.

1895 Acrochordiceras coronatum WAAGEN, p. 96, pl. 3, fig. 5.

1895 Acrochordiceras cf. damesi - WAAGEN, p. 97, pl. 4, fig. 5.

1895 Acrochordiceras compressum - WAAGEN, p. 98, pl. 4, fig. 4.

p 1909 Sibirites sp. indet. - KRAFFT \& DiENER, p. 138, pl. 28, fig. 4 only.

? 1978 Stephanites corona - GUEX, pl. 5, fig. 2.

v 2010b Wasatchites distractus - BRÜHWILER et al., p. 423, fig. 15(1).

v 2012b Wasatchites distractus - BRÜHWILER \& BUCHER, p. 97, figs $81 \mathrm{M}-\mathrm{U}, 82 \mathrm{~A}-\mathrm{X}$.

v 2012c Wasatchites distractus - BRÜHWILER et al., p. 152, fig. $32 \mathrm{~A}-\mathrm{Z}$.

? 2018 Wasatchites cf. distractus - JENKS \& BRAYARD, p. 89, fig. 84.

Occurrence: Anasibirites fauna.

Measurements: See Table 1. Estimated maximal size: $~ 6 \mathrm{~cm}$.

Description: Moderately involute, somewhat compressed shell with convex flanks forming a trapezoidal whorl section. Venter ranging from tabulate on some inner whorls to subtabulate or slightly arched on mature whorls. Ventral shoulders abruptly rounded. Umbilicus moderately deep with a typical oblique wall and rounded shoulders. Ornamentation very conspicuous, consisting of projected ribs varying in strength and width. Ribs typically alternating between strong and weak and may arise from lateral tubercles. Intraspecific variation high, largely depending upon size at which transition between nontuberculate to tuberculate stages occurs. Suture line not available in our material.

Discussion: Wasatchites distractus essentially differs from the type species by the more lateral position of its tubercles on the flank and its more radial and conspicuous ribs whose strength decreases at maturity. The reader is referred to BRAYARD et al. (2013) for a thorough discussion of the genus Wasatchites.

Type species: Sibirites kingianus WAAGEN, 1895

Genus Anasibirites MoJsIsOvics, 1896

See JATTIOT et al. (2015) for thoroughly illustrated specimens from Timor and extensive descriptions and discussions of Anasibirites species.

?Anasibirites sp. indet. A

(Plate 28, Figs I-N)

Occurrence: Anasibirites fauna.

Measurements: See Table 1. Estimated maximal size: $\sim 6.5 \mathrm{~cm}$.

Description: Moderately involute, somewhat compressed shell with convex flanks. Venter subtabulate to rounded with rounded shoulders. Umbilicus moderately deep with a typical oblique wall and rounded shoulders. Ornamentation consists of strong ribs rapidly fading out throughout ontogeny. Last half of outer whorl smooth, except for biconcave growth lines. Suture line not available in our material.

Discussion: This taxon differs from typical representative of Anasibirites by its stronger, more spaced ornamentation and from Wasatchites distractus by the absence of tuberculation and an ornamentation rapidly disappearing throughout ontogeny. It may be considered as an 'intermediate' form between Wasatchites and Anasibirites.

?Anasibirites sp. indet. B

(Plate 28, Fig. O)

Occurrence: Anasibirites fauna.

Measurements: See Table 1. Estimated maximal size: $\sim 5.5 \mathrm{~cm}$.

Description: Moderately involute, compressed shell with convex flanks. Singularly marked egressive coiling of the outer whorl. Venter subtabulate with slightly rounded shoulders. Umbilical shoulders broadly rounded forming a deep umbilicus with inclined wall. Ornamentation very singular, consisting of low folds crossing the venter becoming stronger and more distant throughout the outer whorl but finally disappearing at the visible end of the whorl.

Discussion: This specimen is characterized by an unusual, inconstant ornamentation and a marked egressive coiling.

Type species: Goniodiscus nodosus FREBOLD, 1930 
1929 Kashmirites resseri - MATHEWS, p. 38, pl. 8, figs 4-7.

1932 Kashmirites resseri - SMITH, p. 67, pl. 81, figs 9, 10.

1961 Arctoprionites sp. indet - TOZER, pl. 20, fig. 1.

1962 Arctoprionites sp. indet. - KUMMEL \& STEELE, p. 699, pl. 101, fig. 2.

1994 Arctoprionites williamsi - TozeR, p. 83, pl. 34, figs 1-4.

v 2013 Arctoprionites resseri-BRAYARD et al., p. 198, fig. 67.

v 2017 Arctoprionites resseri - JATTIOT et al., p. 34, pl. 12, figs N-X.

2018 Arctoprionites resseri - JENKS \& BRAYARD, p. 92, figs 86, 87.

Occurrence: Anasibirites fauna.

Measurements: See Text-fig. 52. Estimated maximal size: $\sim 8 \mathrm{~cm}$.

Description: Involute, compressed shell with slightly egressive coiling. Flanks slightly convex and whorl section trapezoidal. Depression near ventral shoulders visible on immature whorls. Venter tabulate with angular shoulders. Venter becoming flat with abruptly rounded shoulders on mature whorls. Umbilical shoulders broadly rounded, with a deep umbilicus and inclined wall. Ornamentation consisting of conspicuous, slightly projected, angular folds or elongated bullae near umbilical margin that fade away near mid-flank. Suture line not available in our material.

Discussion: See BRAYARD et al. (2013) for a comprehensive discussion of the taxon Arctoprionites resseri. The genus Hemiprionites mainly differs by the absence of conspicuous folds or bullae on the upper half of the flanks. To our knowledge, Arctoprionites was previously only known from Utah, Nevada and British Columbia. Thus, this is the first evidence of Arctoprionites from the opposite side of the Panthalassa and it underlines the potential long-distance faunal exchanges that occurred during the Early Triassic.

Genus Hemiprionites SPATH, 1929

Type species: Goniodiscus typus WAAGEN, 1895

Hemiprionites typus (WAAGEN, 1895)

(Plate 29, Figs A-AN)

1895 Goniodiscus typus WAAGEN, p. 128, pl. 9, figs 7-10.

1929 Goniodiscus typus - MATHEWs, p. 31, pl. 5, figs 12-21.

1929 Goniodiscus americanus MATHEWs, p. 32, pl. 5, figs 22-27.

1929 Goniodiscus shumardi MATHEWs, p. 33, pl. 6, figs 11-14.

1929 Goniodiscus utahensis MATHEWs, p. 33, pl. 6, figs 29-31.

1929 Goniodiscus ornatus MATHEWS, p. 34, pl. 6, figs 6-10.

1929 Goniodiscus slocomi MATHEWs, p. 34, pl. 6, figs 15-17.

1929 Goniodiscus butleri MATHEWs, p. 35, pl. 6, figs 18-21.

1932 Anasibirites typus - SMITH, p. 76, pl. 80, figs 6-8.

1932 Anasibirites utahensis - SMITH, p. 77, pl. 80, figs 9, 10.

1932 Anasibirites ornatus - SMITH, p. 75, pl. 80, figs 11, 12.

1934 Hemiprionites typus - SPATH, p. 331, figs 114a-c.

v p 2008 Hemiprionites cf. butleri-BRAYARD \& BUCHER, p. 58, pl. 29, figs 1, 4, 7 only.

v 2012b Hemiprionites typus - BRÜHWILER \& BUCHER, p. 103, figs 89A-AH.

v 2013 Hemiprionites cf. typus - BRAYARD et al., p. 197, fig. 66.

v 2017 Hemiprionites typus - JATTIOT et al., p. 31, pl. 12, figs A-M; pl. 13, figs A-X.

2018 Hemiprionites typus - JENKS \& BRAYARD, p. 81, figs 77, 78, 79A-P.

Occurrence: Anasibirites fauna.

Measurements: See Text-fig. 53. Estimated maximal size: $~ 10 \mathrm{~cm}$.

Description: Involute, compressed shell with deeply embracing whorls and slightly egressive coiling. Flanks convex and convergent with or without an Ambites-like depression (minute depression on outer edge of flank) immediately below ventral shoulders. Depression near ventral shoulders sometimes only present in early ontogeny, then fading away on outer whorl. Maximum whorl width near mid-flank. Venter tabulate to weakly sulcate in rare instances. Ventral area ornamented with spiral lines on wellpreserved specimens. Ventral shoulders angular, or less abrupt on specimens without depression. Umbilical shoulders broadly rounded forming a deep umbilicus with inclined wall. Ornamentation usually consisting of very vague radial folds occasionally crossing the venter. Flexuous growth lines parallel to folds. Suture line ceratitic with rather deep lateral lobes and broad and rounded saddles. 
Discussion: The reader is referred to JATTIOT et al. (2017).

Hemiprionites walcotti (MATHEWS, 1929)

(Plate 29, Figs AO-BG)

p 1922 Anasibirites multiformis WeLTER, p. 138, pl. 17, figs 4-7, 11-14 only.

1929 Goniodiscus walcotti MATHEWs, p. 32, pl. 6, figs 1-5.

1934 Hemiprionites timorensis SPATH, p. 331.

v p 2008 Hemiprionites cf. butleri - BRAYARD \& BUCHER, p. 58, pl. 29, figs 2, 3, 6 only.

v 2008 Hemiprionites klugi BRAYARD \& BUCHER, p. 59, pl. 30, figs 1-4.

v p 2012a Hemiprionites cf. butleri - BRÜHWILER \& BUCHER, p. 33, pl. 19, fig. 10 only.

v p 2012b Anasibirites angulosus - BRÜHWILER \& BUCHER, p. 103, figs 87H-J, N-P only.

v 2012b Hemiprionites klugi - BRÜHWILER \& BUCHER, p. 103, figs 87Q-AB.

v 2017 Hemiprionites walcotti - JATTIOT et al., p. 34, pl. 14, figs A-Y.

2018 Hemiprionites walcotti - JENKS \& BRAYARD, p. 81, fig. 79Q-V.

Occurrence: Anasibirites fauna.

Measurements: See Text-fig. 54. Estimated maximal size: $6.5 \mathrm{~cm}$.

Description: Coiling involute throughout juvenile stages, becoming slightly egressive at maturity. Compressed shell with tabulate venter (as a general rule thinner than $H$. typus), angular or abruptly rounded ventral shoulders and convex flanks with maximum curvature at mid-flank. Ventral area ornamented with spiral lines on well-preserved specimens. Umbilicus deep with steeply inclined wall, very narrow at juvenile stages and becoming slightly more open at mature stages. Umbilical shoulders broadly rounded. Very vague radial folds occasionally crossing the venter occurring in a few variants. Flexuous growth lines parallel to folds when present. Suture line ceratitic, with tapered first and second lateral saddles.

Discussion: The reader is referred to JATTIOT et al. (2017). Hemiprionites walcotti differs from $H$. typus by its more involute coiling, its greater whorl height and its narrower venter.

\section{Superfamily Sagecerataceae HYATT, 1884 \\ Family Hedenstroemiidae WAAGEN, 1895 \\ Genus Hedenstroemia WAAGEN, 1895}

Type species: Ceratites hedenstroemi KEYSERLING, 1845

Hedenstroemia evoluta (SPATH, 1934)

(Plate 30, Figs A-O)

1905 Hedenstroemia mojsisovicsi - FRECH, pl. 27, fig. 4.

? 1922 Hedenstroemia waageni WELTER, p. 96, pl. 1, fig. 3, text-figs 5, 6.

1934 Anahedenstroemia evoluta SPATH, p. 219, pl. 6, fig. 6.

2012b Hedenstroemia evoluta - BRÜHWILER \& BUCHER, p. 109, fig. 94A-Q.

Occurrence: Kashmirites fauna.

Measurements: See Text-fig. 55. Estimated maximal size: $\sim 9 \mathrm{~cm}$.

Description: Very involute shell with strong egressive coiling on outer whorl and convergent flanks. Venter narrow and tabulate with angular shoulders. Umbilicus small and deep with vertical wall and abruptly rounded shoulders. Surface smooth except for falcoid growth lines associated with very vague folds on lower half of flanks. Suture line ceratitic and complex with one adventitious lobe and a long, well-individualized auxiliary series.

Discussion: According to SPATH (1934), this species differs from Hedenstroemia waageni WeLtER, 1922 from Timor by being more evolute. However, this is probably only due to the size difference between the two type specimens that may actually be conspecific. H. kossmati HyATT \& SMITH, 1905 does not show an egressive coiling.

Genus Mesohedenstroemia CHAO, 1959

Type species: Mesohedenstroemia kwangsiana СНАО, 1959

Mesohedenstroemia kwangsiana CHAO, 1959

(Plate 30, Figs $\mathrm{P}-\mathrm{X}$ )

? $1895 \quad$ Parakymatites discoides WAagen, p. 214, pl. 36, fig. 3.

1959 Mesohedenstroemia kwangsiana CHAO, p. 266, pl. 34, figs 1-18.

1959 Mesohedenstroemia inflata CHAO, p. 267, pl. 35, figs 4-8.

v 2008 Mesohedenstroemia kwangsiana - BRAYARD \& BUCHER, p. 75, pl. 41, figs 1-8. 
2018 Mesohedenstroemia kwangsiana - JENKs \& BRAYARD, p. 114, fig. 106A-L.

Occurrence: Kashmirites fauna.

Measurements: See Table 1. Estimated maximal size: $~ 5.5 \mathrm{~cm}$.

Description: Very involute, compressed shell with subparallel flanks. Venter relatively broad and tabulate with angular shoulders. Umbilicus narrow, deep, with perpendicular wall and abruptly rounded shoulders. Surface smooth except for growth lines, curving slightly forward near venter, when shell is well preserved. Suture line not available in our material.

Discussion: This species differs from Hedenstroemia evoluta (SPATH, 1934) by its wider venter and its simple suture line without adventious elements (BRAYARD \& BUCHER 2008). For a thorough discussion, the reader is referred to BRAYARD \& BUCHER (2008).

\section{Genus Pseudosageceras DIENER, 1895}

Type species: Pseudosageceras sp. indet. DIENER, 1895

\section{Pseudosageceras multilobatum NoETLING, 1905}

\section{(Plate 31, Figs A-W)}

1905 Pseudosageceras multilobatum NoETLING, pl. 25, fig. 1, pl. 26, fig. 3.

1905 Pseudosageceras intermontanum HyATт \& SмIтH, p. 99, pl. 4, figs 1-3; pl. 5, figs 1-6; pl. 63, figs 1, 2.

1909 Pseudosageceras multilobatum - KRAFFT \& DiENER, p. 145, pl. 21, fig. 5.

1911 Pseudosageceras drinense ARTHABER, p. 201, pl. 17, figs 6, 7.

1913 Pseudosageceras multilobatum - WANNER, p. 181, pl. 7, fig. 4.

1922 Pseudosageceras multilobatum - WeLTER, p. 94, fig. 3.

1929 Pseudosageceras intermontanum - MATHEWs, p. 3, pl. 1, figs 18-22.

1932 Pseudosageceras multilobatum - SMITH, p. 87-89, pl. 4, figs 1-3; pl. 5, figs 1-6; pl. 60, fig. 32; pl. 63, figs 1-6.

1934 Pseudosageceras multilobatum - Collignon, p. 56-58, pl. 11, fig. 2.

1934 Pseudosageceras multilobatum - SPATH, p. 54, fig. 6a.

1947 Pseudosageceras multilobatum - KIPARISOVA, p. 127, pl. 25, figs 3, 4.

1947 Pseudosageceras multilobatum var. giganteum - KIPARISOVA, p. 127, pl. 26, figs 2-5.

1948 Pseudosageceras cf. clavisellatum - RENZ \& RENZ, p. 90, pl. 16, fig. 3.

1948 Pseudosageceras drinense - RENZ \& RENZ, p. 92, pl. 16, fig. 6.

1948 Pseudosageceras intermontanum - RENZ \& RENZ, p. 90, pl. 16, figs 4, 7.

1959 Pseudosageceras multilobatum - CHAO, p. 183, pl. 1, figs 9, 12.

1959 Pseudosageceras tsotengense CHAO, p. 184, pl. 1, figs 7, 8, text-fig. 5b.

1959 Pseudosageceras curvatum CHAO, p. 185, pl. 1, figs 13, 14, text-fig. 5a.

? 1959 Pseudosageceras multilobatum var. nov. - JEANNET, p. 30, pl. 6, fig. 1.

1961 Pseudosageceras schamarense - KIPARISOVA, p. 31, pl. 7, fig. 3.

1961 Pseudosageceras multilobatum var. gigantea - PoPOV, p. 13, pl. 2, figs 1, 2.

? $1966 \quad$ Pseudosageceras multilobatum - HADA, p. 112, pl. 4, fig. 6.

? 1968 Pseudosageceras multilobatum - KUMMEL \& ERBEN, p. 112, pl. 19, fig. 9.

1968 Pseudosageceras multilobatum - SHEVYREV, p. 791, pl. 1, figs 1, 2.

? 1973 Pseudosageceras multilobatum-Collignon, p. 5, pl. 1, fig. 1.

1978 Pseudosageceras multilobatum - WeITSCHAT \& LEHMANN, p. 95, pl. 10, figs 2ab.

1984 Pseudosageceras multilobatum - VU KHUC, p. 26, pl. 1, fig. 1.

1994 Pseudosageceras multilobatum - TOZER, p. 83, pl. 18, figs 1a, b; p. 384, fig. 17.

v 2008 Pseudosageceras multilobatum - BRAYARD \& BUCHER, p. 70, pl. 37, figs 1-5.

2010 Pseudosageceras multilobatum - STEPHEN et al., figs 6c, d, h.

v 2010b Pseudosageceras multilobatum - BRÜHWILER et al., p. 429, fig. 16(14).

v 2012a Pseudosageceras multilobatum - BRÜHWILER \& BUCHER, p. 47, pl. 26, fig. 4.

v 2012b Pseudosageceras multilobatum - BRÜHWILER \& BUCHER, p. 109, figs 95A-N.

v 2013 Pseudosageceras multilobatum - BRAYARD et al., p. 208, fig. 77.

2014 Pseudosageceras multilobatum - SHIGETA \& NGUYEN, p. 137, figs 98, 99.

v 2017 Pseudosageceras multilobatum - JATTIOT et al., p. 41, pl. 19, figs A-I.

2018 Pseudosageceras multilobatum - JENKS \& BRAYARD, p. 111, fig. 102A-M.

Occurrence: Kashmirites and Owenites faunas.

Measurements: See Text-fig. 56. Estimated maximal size: $14 \mathrm{~cm}$.

Description: Extremely involute, compressed oxyconic shell with an occluded umbilicus. As a general rule, venter extremely narrow and bicarinate. Specimens PIMUZ 37272 and PIMUZ 37273 (Pl. 31, Figs $\mathrm{K}-\mathrm{R}$ ) are variants with a relatively wide venter. On the contrary, specimens PIMUZ 37274 and PIMUZ 37275 (Pl. 31, Figs S-W) are variants with an acute venter, no longer bicarinate. Flanks weakly convex, 
convergent from umbilicus to venter. Surface smooth without ornamentation. Suture line ceratitic, complex and composed of many adventitious elements with characteristic trifid lateral lobe. Other lobes are bifid.

Discussion: Many specimens previously illustrated as Pseudosageceras multilobatum seem to show an acute, non-bicarinate venter (e. g., HYATT \& SMITH 1905: pl. 5, fig. 1, 2; TOZER 1994: pl. 18, fig. 1a-b; BRAYARD et al. 2013: fig. 77a-b; JATTIOT et al. 2017: pl. 19, Figs A-C; JENKS \& BRAYARD 2018: fig. 102) and two of our Timor specimens ( $\mathrm{Pl}$. 31, Figs S-W) unequivocally confirm this unusual feature. Interestingly, TOzER (1994) also notices this feature, as he writes that one of his specimen "has a narrowly tabulate venter at the beginning of the outer whorl, where part of the test is preserved. On the greater part, which apparently nowhere preserves the full thickness of the test, the venter is narrowly rounded”. However, our Timor specimens exhibiting a non-bicarinate venter bear a very well-preserved test. This could imply that TOzER's (1994) observation is not due to preservation but instead indicates an actual change in venter shape throughout ontogeny of the same specimen. This is corroborated by SPATH (1934) who describes the species $P$. drinense ARTHABER, 1911 (now commonly considered as a synonym of $P$. multilobatum) with a venter "at first narrowly tabulate, later acute (in some examples?)". Thus, $P$. multilobatum is proved to show a great intraspecific variation in venter shape, from more or less narrow bicarinate venter to acute venter (see also JENKS \& BRAYARD 2018).

Type species: Sageceras wynnei WAAGEN, 1887

Genus Episageceras NOETLING, 1904

\section{Episageceras cf. intermedium WELTER, 1922}

(Plate 31, Figs X-AA)

1922 Episageceras intermedium WELTER, p. 93, pl. 1, figs 1, 2.

Occurrence: Kashmirites fauna.

Measurements: See Table 1. Estimated maximal size: $2.5 \mathrm{~cm}$.

Description: Very involute, very compressed shell with a narrow tabulate venter and very angular ventral shoulders resembling keels. Subparallel flanks. Umbilicus very narrow, with moderately high, perpendicular wall and abruptly rounded shoulders. Surface smooth, except for barely conspicuous growth lines. Suture line typical of the genus, composed of many adventitious elements with bifid lobes; lateral saddles slightly phylloid; complex ventral saddle.

Discussion: Our single specimen is morphologically similar to the holotype of Episageceras intermedium WELTER, 1922, but the very small size of our specimen precludes a definitive assignment.

Episageceras sp. indet.

(Plate 31, Figs AB-AF)

Occurrence: Owenites fauna.

Measurements: See Table 1. Estimated maximal size: $2 \mathrm{~cm}$.

Description: Very involute, compressed shell with flat, parallel flanks. Venter subtabulate with very angular shoulders. Surface smooth. Suture line typical of the genus, composed of many adventitious elements with bifid lobes; lateral saddles slightly phylloid. Ventral saddle characteristic of the genus not preserved.

Discussion: The scarcity and the small size of the material preclude an assignment at the species level. This taxon mainly differs from the older taxon Episageceras cf. intermedium by its subtabulate venter.

Family Aspenitidae SPATH, 1934

Genus Aspenites HYATT \& SMITH, 1905

Type species: Aspenites acutus HYATT \& SMITH, 1905

Aspenites acutus HYATT \& SMITH, 1905

(Plate 32, Figs AE-AH)

1905 Aspenites acutus HyATT \& SMITH, 1905, p. 96, pl. 2, figs 9-13; pl. 3, figs 1-5.

? 1909 Hedenstroemia acuta KRAFFT \& DiEnER, p. 157, pl. 9, fig. 2.

1922 Aspenites acutus - WELTER, p. 98, fig. 7.

1922 Aspenites laevis WELTER, p. 99, pl. 1, figs 4, 5.

1932 Aspenites acutus - SMITH, p. 86, pl. 2, figs 9-13, pl. 3, figs 1-5, pl. 30, figs 1-26, pl. 60, figs 4-6.

1932 Aspenites laevis - SMITH, p. 86, pl. 28, figs 28-33. 
1932

1934

? 1934

1957

1959

1959

1962

1962

1962

1979

1979

V 2008

2010

2010b

2012a

2012c

2013

2017

2018

Aspenites obtusus SMITH, p. 86, pl. 31, figs 8-10.

Aspenites acutus - SPATH, p. 229, fig. 76.

Parahedenstroemia acuta - SPATH, p. 221, fig. 70.

Aspenites acutus - KUMMEL, p. L142, fig. 173a-c.

Aspenites acutus - CHAO, p. 269, pl. 35, figs 12-18, 23, text-fig. 34a.

Aspenites laevis - CHAO, p. 270, pl. 35, figs 9-11, text-fig. 34b.

Aspenites acutus - KUMMEL \& STEELE, p. 692, pl. 99, figs 16-17.

Hemiaspenites obtusus - KUMMEL \& STEELE, p. 666, pl. 99, fig. 18.

Pseudosageceras multilobatum - KUMMEL \& STEELE, p. 701, pl. 102, figs 1, 2.

Aspenites cf. acutus - NiCHOLS \& SILBERLING, pl. 1, figs 10-11.

Aspenites acutus - NiCHOLS \& SilBERLING, pl. 1, figs 12-14.

Aspenites acutus - BRAYARD \& BUCHER, p. 77, pl. 42, figs 1-9.

Aspenites acutus - STEPHEN et al., fig. $4 \mathrm{f}$.

Aspenites acutus - BRÜHWILER et al., p. 429, fig. 16(12, 13).

Aspenites acutus - BRÜHWILER \& BUCHER, p. 48, pl. 26, figs 1, 2.

Aspenites acutus - BRÜHWILER et al., p. 164, figs 41A-M.

Aspenites acutus - BRAYARD et al., p. 212, fig. 81.

Aspenites acutus - JATTIOT et al., p. 44, pl. 18, figs A-H.

Aspenites acutus - JENKS \& BRAYARD, p. 118, figs 109, 115A-D.

Occurrence: Owenites fauna. One single specimen.

Measurements: See Text-fig. 57 . Estimated maximal size: $7.5 \mathrm{~cm}$.

Description: Extremely involute, very compressed oxyconic shell with an occluded umbilicus. Maximum curvature at mid-flank. Venter with a characteristic acute keel. Flanks slightly convex. Umbilical region slightly depressed. Surface nearly smooth except for fine radial folds and falcoid growth lines. Suture line not available in our material.

Discussion: Aspenites weitschati JENKS \& BRAYARD, 2018 is distinguished mainly by its more compressed shell and much larger adult size. A. acutus mainly differs from other aspenitid taxa (e.g., Pseudaspenites layeriformis) by its slightly depressed umbilical region and its occluded umbilicus. However, P. layeriformis and P. acutus are almost indistinguishable at a diameter of less than $20 \mathrm{~mm}$ since $P$. layeriformis exhibits a nearly occluded umbilicus at that size.

Type species: Aspenites layeriformis WELTER, 1922

Genus Pseudaspenites SPATH, 1934

Pseudaspenites layeriformis (WELTER, 1922)

(Plate 32, Figs A-AD)

1922 Aspenites layeriformis WeLTER, p. 97, pl. 1, figs 6-8.

1934 Pseudaspenites layeriformis - SPATH, p. 230, fig. 77.

1959 Inyoites striatus CHAO, p. 197, pl. 2, figs 22-26.

1959 Inyoites obliqueplicatus CHAO, p. 198, pl. 2, figs 7, 17-21, 27.

non v 2008 Pseudaspenites layeriformis - BRAYARD \& BUCHER, p. 79, pl. 43, figs 1-6.

2012a Pseudaspenites layeriformis - BRÜHWILER \& BUCHER, p. 48, pl. 26, fig. 3a-b.

2012c Pseudaspenites cf. layeriformis - BRÜHWILER et al., p. 169, fig. 41N-Y.

Occurrence: Owenites fauna.

Measurements: See Text-fig. 58. Estimated maximal size: $~ 8.5 \mathrm{~cm}$.

Description: Very involute, very compressed oxyconic shell similar to Aspenites, but with an egressive coiling. Flanks slightly convex, strongly converging on the lowermost part. Venter acutely keeled, although less compressed variants (e.g., Plate 32, Figs L- M) do not bear a keel but an acute venter only. Umbilicus shallow and narrow with rounded shoulders and inclined umbilical wall. Surface nearly smooth except for falcoid growth lines and fine falcoid folds. Suture line ceratitic with an adventitious lobe and a well-individualized auxiliary series.

Discussion: Small-sized specimens from South China described as Pseudaspenites layeriformis by BRAYARD \& BUCHER (2008) are significantly more evolute than our juvenile specimens (exhibiting a nearly occluded umbilicus at the same size), some of them bear a crenulated keel that is not observed in any of our exceptionally well-preserved specimens, and they are older (early Smithian, Flemingites rursiradiatus beds). Therefore, we hypothesize that these specimens from South China do not belong to P. layeriformis and are instead representatives of P. evolutus BRAYARD \& BUCHER, 2008. 
Type species: Ussuria schamarae DIENER, 1895

Ussuria schamarae DIENER, 1895

(Plate 33, Figs A-C)

1895 Ussuria schamarae DIENER, p. 26, pl. 3, fig. 4.

1895 Ussuria iwanowi DIENER, p. 27, pl. 3, fig. 5.

? 1922 Ussuria nov. sp. ind. ex. aff. iwanowi - WelteR, p. 100, pl. 3, fig. 10.

Occurrence: Owenites fauna.

Measurements: See Text-fig. 59. Estimated maximal size: $\sim 7 \mathrm{~cm}$.

Description: Compressed, very involute, deeply embracing shell with whorls increasing rapidly in height. Venter narrowly rounded. Flanks convex and convergent. Maximum thickness slightly above midflanks. Umbilicus narrow and deep, with broadly rounded umbilical shoulders. Delicate strigation visible on venter. Suture line not available in our material.

Discussion: DIENER (1895) erected two species of Ussuria: U. schamarae and U. iwanowi. We here consider that $U$. iwanowi actually represents a later ontogenetic stage of the type species. According to BRAYARD \& BUCHER (2008), U. kwangsiana CHAO, 1959 from China is more laterally compressed.

?Parussuria sp. indet.

(Plate 33, Figs D-G)

Occurrence: Owenites fauna.

Measurements: See Table 1. Estimated maximal size: $\sim 2.5 \mathrm{~cm}$.

Description: Extremely involute, compressed oxycone with a rounded venter. Flanks slightly convex. Occluded umbilicus. Surface smooth except for delicate lirae. Suture line typical of ussuriids with highly frilled lobes and saddles.

Discussion: The small size of the specimen hinders any assignment at the species level and the assignment to Parussuria, based on the shape of the suture lines, is tentative only.

Order Phylloceratida ZITTEL, 1884

Superfamily Ussuritaceae HYATT, 1900

Family Palaeophyllitidae POPOV, in LUPPOV \& DRUSHCHITS, 1958

Genus Goudemandites BRÜHWILER \& BUCHER, 2012a

Type species: Goudemandites sinensis BRÜHWILER \& BUCHER, 2012a

Goudemandites cf. sinensis BRÜHWILER \& BUCHER, 2012a

(Plate 33, Fig. K)

v 2008 ?Palaeophyllitidae gen. indet. - BRAYARD \& BUCHER, p. 85, pl. 7, fig. 7.

v 2012a Goudemandites sinensis BRÜHWILER \& BUCHER, p. 50, pl. 26, fig. 5.

Occurrence: Owenites fauna.

Measurements: See Table 1. Estimated maximal size: $\sim 4.5 \mathrm{~cm}$.

Description: Moderately evolute, somewhat compressed shell with convex, convergent flanks. Venter rounded with indistinct shoulders. Umbilicus moderately deep with vertical wall and rounded shoulders. Ornamentation very poorly preserved on our specimens, but usually consists of biconcave plications and lirae that do not cross the venter (BRÜHWILER \& BUCHER 2012a). Suture line not available in our material. Discussion: The absence of suture line prevents a firm assignment to the type species.

Palaeophyllitidae gen. et sp. indet.

(Plate 33, Figs H-J)

Occurrence: Smithian.

Measurements: See Table 1. Estimated maximal size: $~ 7 \mathrm{~cm}$.

Description: Evolute, somewhat depressed shell with convergent flanks from umbilical shoulders. Ventre broadly rounded, becoming narrowly rounded at maturity. Maximum thickness at umbilical shoulders. Umbilicus wide and shallow, with broadly rounded umbilical shoulders. Surface smooth except for dense radial lirae and barely discernible constrictions on inner whorls.

Discussion: This specimen might be a large representative of the species 'Prenkites' sundaicus WELTER, 1922 from the "Meekoceras-Kalke" of Timor that is assumed to be of early Smithian age, since it is located stratigraphically below the "Owenites-Kalke” according to WELTER (1922). However, there is no 
age control for our specimen, making any assignment impossible. We tentatively assign this taxon to the Palaeophyllitidae family based on its serpenticonic coiling and its dense, radial lirae.

\section{Family Incertae sedis}

Genus gen. et sp. indet.

(Plate 22, Figs R-T)

Occurrence: Owenites fauna.

Measurements: See Table 1. Estimated maximal size: $1.5 \mathrm{~cm}$.

Description: Small, moderately evolute shell with an arched venter and flanks convergent from umbilical shoulders to rounded venter (without distinct ventral shoulders). Moderately deep umbilicus with relatively high, steeply inclined wall and somewhat abruptly rounded shoulders. Ornamentation consists of barely conspicuous constrictions crossing the venter with equal intensity. Suture line not available in our material.

Discussion: This specimen is roughly morphologically similar to typical representatives of $J$. septentrionalis but is distinguished by its barely conspicuous constrictions.

\section{Subclass Nautiloidea AgASsiz, 1847 \\ Order Nautiloida AGASSIZ, 1847 \\ Family Tainoceratidae HYATT, 1884 \\ Genus gen. indet.}

(Plate 33, Figs L-N)

Occurrence: Kashmirites fauna.

Description: Moderately involute shell with a marked egressive coiling at maturity and a subquadratic whorl section. Biconcave aperture. Flanks flat and slightly convergent. Venter very broad and subtabulate with rounded shoulders. Umbilicus with high, vertical wall and abruptly rounded shoulders. Ornamented with rursiradiate ribs fading out on last half of the outer whorl and bearing umbilical and ventral nodes; as well as biconcave growth lines. Suture line not available in our material.

\section{Acknowledgements}

Claude Monnet (Lille) is thanked for providing his statistical analyses software. Technical support for preparation and photography was provided by Markus Hebeisen and Rosemarie Roth (Zürich). This work is a contribution to the ANR project AFTER (ANR-13-JS06-0001-01, to A. B.), to the Swiss NSF project 200020_160055 (to H. B.), and was also supported by the French "Investissements d'Avenir" program, project ISITE-BFC (ANR-15-IDEX-03, to A. B.).

\section{References}

ARthaber, G. (1911): Die Trias von Albanien. - Beitr. Paläontol. und Geol. Österreich-Ungarns und des Orients 24: 169-288.

BANDO, Y. (1981): Lower Triassic ammonoids from Guryul Ravine and the spur three kilometers north of Barus. - In: NAKAZAWA, K. \& KAPOOR, H. M. (eds): The Upper Permian and Lower Triassic fossils of Kashmir. - Paleontol. Indica 46: 135-178.

Baresel, B., Bucher, H., Brosse, M., Cordey, F., Guodun, K., \& Schaltegger, U. (2017): Precise age for the Permian-Triassic boundary in South China from high-precision U-Pb geochronology and Bayesian age-depth modeling. - Solid Earth 8 (2): 361-378.

BRAYARD, A. \& BUCHER, H. (2008): Smithian (Early Triassic) ammonoid faunas from northwestern Guangxi (South China): taxonomy and biochronology. - Fossils and Strata 55: 1-179.

Brayard, A. \& Bucher, H. (2015): Permian-Triassic Extinctions and Rediversifications. - In: KLUG, C., Korn, D., DE BAETS, K., KRUtA, I. \& MAPES, R.H. (eds): Ammonoid Paleobiology: From macroevolution to paleogeography. - Topics in Geobiology 44: 465-473.

Brayard, A., Bucher, H., Escarguel, G., Fluteau, F., Bourquin, S. \& Galfetti, T. (2006): The Early Triassic ammonoid recovery: Paleoclimatic significance of diversity gradients. - Palaeogeogr. Palaeoclimatol. Palaeoecol. 239: 374-395.

Brayard, A., Escarguel, G., Bucher, H., Monnet, C., Brühwiler, T., Goudemand, N., Galfetti, T. \& GueX, J. (2009a): Good genes and good luck: Ammonoid diversity and the end-Permian mass extinction. - Science 325: $1118-1121$.

Brayard, A., BrüHwiler, T., Bucher, H. \& JenKs, J. (2009b): Guodunites, a low-palaeolatitude and trans-Panthalassic Smithian (Early Triassic) ammonoid genus. - Palaeontol. 52: 471-481. 
Brayard, A., Bylund, K.G., Jenks, J.F., Stephen, D.A., Olivier, N., Escarguel, G., Fara, E. \& Vennin, E. (2013): Smithian ammonoid faunas from Utah: implications for Early Triassic biostratigraphy, correlation and basinal paleogeography. - Swiss J. Palaeontol. 132 (2): 141-219.

BrÜHWILER, T. \& Bucher, H. (2012a): Systematic Palaeontology. - In: BrÜHwiler, T., BuCHER, H., GOUdEMAND, N. \& GAlfETTI, T. (eds): Smithian (Early Triassic) ammonoids faunas from Exotic Blocks from Oman: taxonomy and biochronology. - Palaeontographica Abt. A 296: 13-107.

Brühwiler, T. \& BuCher, H. (2012b): Systematic Palaeontology. - In: BrühWiler, T., BuChER, H., WARE, D., Hermann, E., Hochuli, P.A., RoOHI, G., RehMAN K. \& YASEen A. (eds): Smithian (Early Triassic) ammonoids from the Salt Range. - Spec. Pap. Palaeontol. 88: 22-111.

BrüHWiler, T., Bucher, H., Brayard, A. \& GoudEMAND, N. (2010a): High-resolution biochronology and diversity dynamics of the Early Triassic ammonoid recovery: the Smithian faunas of the Northern Indian Margin. Palaeogeogr. Palaeoclimatol. Palaeoecol. 297: 491-501.

Brühwiler, T., Bucher, H. \& Goudemand, N. (2010b): Smithian (Early Triassic) ammonoids from Tulong, South Tibet. - Geobios 43: 403-431.

Brühwiler, T., Ware, D., Bucher, H., Krystyn, L. \& Goudemand, N. (2010c): New Early Triassic ammonoid faunas from the Dienerian/Smithian boundary beds at the Induan/Olenekian GSSP candidate at Mud (Spiti, Northern India). - J. Asian Earth Sci. 39: 724-739.

Brühwiler, T., Bucher, H., RoOhi, G., Yaseen, A. \& Rehman, K. (2011): A new early Smithian ammonoid fauna from the Salt Range (Pakistan). - Swiss J. Palaeontol. 130 (2): 187-201.

BrüHWIlER, T., BuCher, H., Goudemand, N. \& GAlfetTI, T. (2012a): Smithian (Early Triassic) ammonoids faunas from Exotic Blocks from Oman: taxonomy and biochronology. - Palaeontographica Abt. A 296: 3-107.

Brühwiler, T., Bucher, H., Ware, D., Hermann, E., Hochuli, P.A., RoOhi, G., Rehman, K. \& Yaseen, A. (2012b): Smithian (Early Triassic) ammonoids from the Salt Range. - Spec. Pap. Palaeontol. 88: 1-114.

BrüHWILER, T., Bucher, H. \& Krystyn, L. (2012c): Middle and late Smithian (Early Triassic) ammonoids from Spiti, India. - Spec. Pap. Palaeontol. 88: 115-174.

CHAO, K. (1959): Lower Triassic ammonoids from Western Kwangsi, China. - Palaeontol. Sinica B 9: 1-355.

Charlton, T. R., Barber, A. J., Mcgowan, A. J., Nicoll, R. S., Roniewicz, E., CoOK, S. E., BARKham, S. T. \& BIRD, P. R. (2009): The Triassic of Timor: Lithostratigraphy, chronostratigraphy and palaeogeography. - J. Asian Earth Sci. 36: 341-363.

Collignon, M. (1933-1934): Paléontologie de Madagascar XX - Les céphalopodes du Trias inférieur. - Ann. Paléontol. 12-13: 151-162 \& 1-43.

Collignon, M. (1973): Ammonites du Trias inférieur et moyen d’Afghanistan. - Ann. Paléontol. (Invertébrés) 59: 127163.

DE KonincK, L.G. (1863): Description of some fossils from India, discovered by Dr. A. Fleming, of Edingburgh. Quart. J. Geol. Soc. London 19: 1-19.

Diener, C. (1895): Triadische Cephalopodenfaunen der ostsibirischen Küstenprovinz. - Mém. Comité Géol. St. Petersburg 14: 1-59.

DiENER, C. (1897): The Cephalopoda of the Lower Trias. - Palaeontol. Indica Himalayan Fossils 15 (2): 1-181.

DIENER, C. (1913): Triassic faunae of Kashmir. - Palaeontol. Indica 5: 1-133.

Diener, C. (1915): Fossilium Catalogus I, Animalia. Part 8, Cephalopoda Triadica. - Berlin (W. Junk).

FREBOLD, H. (1930): Die Altersstellung des Fischhorizontes, des Grippianniveaus und des unteren Saurierhorizontes in Spitzbergen. - Scrifter om Svalbard og Ishavet 28: 1-36.

FRECH, F. (1902): Die Dyas: Lethaea Geognostica, Theil I. - Lethaea Palaeozoica 2: 579-788.

FRECH, F. (1905): Das Mesozoicum: Lethaea Geognostica, Theil II, Trias. - pp. 1-623 (Schweizerbart) Stuttgart.

GuEX, J. (1968): Sur deux conséquences particulières des traumatismes du manteau des ammonites. - Bull. Soc. vaud. sci. nat. 70: 121-126.

GuEX, J. (1978): Le Trias inférieur des Salt Ranges (Pakistan): problèmes biochronologiques. - Eclogae Geologicae Helvetiae 71: 105-141.

HADA. S. (1966): Discovery of Early Triassic ammonoids from Gua Musang, Kelantan, Malaya. - J. Geosci. Osaka Univ. 9: 111-121.

HAMMER, O. \& BUCHER, H. (2005): Buckman's first law of covariation - a case of proportionality. - Lethaia 38: 67-72.

HyATT, A. (1884): Genera of fossil cephalopods. - Proc. Boston Soc. Nat. Hist. 22: 253-338.

HyAtт, A. (1900): Cephalopoda. - In: ZiTTEL, K. A. v. (ed.): Textbook of paleontology 1, 1st English ed. - London (Eastman).

HyatT, A. \& Smith, J. P. (1905): The Triassic cephalopod genera of America. - U.S. Geol. Surv., prof. pap 40: 1-394.

Jattiot, R., Bucher, H., Brayard, A., Monnet, C., Jenks, J. F. \& Hautmann, M. (2015): Revision of the genus Anasibirites Mojsisovics (Ammonoidea): an iconic and cosmopolitan taxon of the late Smithian (Early Triassic) extinction. - Pap. Palaeontol. 2 (1): 155-188.

Jattiot, R., Bucher, H., Brayard, A., Brosse, M., Jenks, J. F. \& BYlund, K. G. (2017): Smithian ammonoid faunas from northeastern Nevada: implications for Early Triassic biostratigraphy and correlation within the western USA basin. - Palaeontographica Abt. A 309 (1-4): 1-89. 
JeAnnet, A. (1959): Ammonites Permiennes et faunes Triassiques de l'Himalaya Central (Expédition Suisse A. Heim et A. Gansser, 1936). - Palaeontol. Indica 34: 1-190.

JENKS, J. (2007): Smithian (Early Triassic) ammonoid biostratigraphy at Crittenden Springs, Elko County, Nevada and a new ammonoid from the Meekoceras gracilitatis Zone. - New Mexico Mus. Nat. Hist. and Sci. Bull. 40: 81-90.

Jenks, J. F., Brayard, A., BrÜHwiler, T. \& Bucher, H. (2010): New Smithian (Early Triassic) ammonoids from Crittenden Springs, Elko County, Nevada: Implications for taxonomy, biostratigraphy and biogeography. - New Mexico Mus. Nat. Hist. and Sci. Bull. 48: 1-41.

JENKS, J. F \& BRAYARD, A. (2018): Smithian (Early Triassic) ammonoids from Crittenden Springs, Elko County, Nevada: taxonomy, biostratigraphy and biogeography. - New Mexico Mus. Nat. Hist. and Sci. Bull. 78: 1-175.

Keyserling, A. (1845): Beschreibung einiger von Dr. A. Th. v. Middendorff mitgebrachten Ceratiten des arctischen Sibiriens. - Bull. Acad. Imp. Sci. St. Pétersbourg 5: 161-174.

KHUC, V. (1984): Triassic ammonoids in Vietnam. - pp. 1-134 (Geoinformation and Geodata Institute) Hanoi.

KIPARISOVA, L. D. (1947): Triassic sediments of the USSR. Atlas of the guide forms of the fossil faunas of the USSR. Transact. All Union Sci. Geol. Res. Inst. (VSEGEI) 7: 5-51; Leningrad.

KipArisovA, L. D. (1956): Materials on paleontology, new families and genera. - Transact. All Union Sci. Geol. Res. Inst. (VSEGEI) 12: 76-79; Leningrad.

KIPARISOVA, L. D. (1961): Palaeontological fundamentals for the stratigraphy of Triassic deposits of the Primor'ye region, I, Cephalopod Mollusca. - Transact. All Union Sci. Res. Geol. Inst. (VSEGEI) 48.

KORCHINSKAYA, M. V. (1982): Explanatory note on the biostratigraphic scheme of the Mesozoic (Trias) of Spitsbergen. - USSR Minist. Geol., PGO Sevmorgeologia: 40-99.

Krafft, A.v. \& Diener, C. (1909): Lower Triassic Cephalopoda from Spiti, Malla Johar, and Byans. - Palaeontol. Indica, 15 (6): 1-186.

KuENZI, W. D. (1965): Early Triassic (Scythian) ammonoids from northeastern Washington. - J. Paleontol. 39: 365-378.

KumMEL, B. (1952): A classification of the Triassic ammonoids. - J. Paleontol. 26: 847-853.

Kummel, B. (1957): Systematic descriptions, L138-L139, L142-L143. - In: MOORE, R. C., RoBISON, R. A. ARKELL, W. J., Furnish, W. M., Kummel, B., Miller, A. K., Schindewolf, O., Sylvester-Bradley, P. C. \& Wright, C. W. (eds): Cephalopoda Ammonoidea. Treatise on Invertebrate Paleontology Part L, Mollusca 4. - pp. 1-490 (Geological Society of America) Boulder, Colorado.

KummeL, B. (1959): Lower Triassic ammonoids from Western Southland, New Zealand. - New Zealand J. Geol. and Geophys. 2: 429-447.

KumMEL, B. (1968a): Scythian ammonoids from Timor. - Breviora 283: 1-21.

Kummel, B. (1968b): Additional Scythian ammonoids from Afghanistan. - Bull. Mus. Comp. Zool., Harvard Univ. 136: 483-509.

KumMEL, B. \& SAKAGAMI, S. (1960): Mid-Scythian ammonites from Iwai Formation, Japan. - Breviora 126: 1-11.

Kummel, B. \& Steele, G. (1962): Ammonites from the Meekoceras gracilitatus Zone at Crittenden Spring, Elko County, Nevada. - J. Paleontol. 36: 638-703.

Kummel, B. \& ERBEN, H. K. (1968): Lower and Middle Triassic cephalopods from Afghanistan. - Palaeontographica Abt. A 129: 95-148.

Luppov, N. P. \& DRUSHCHITS, V. V. (1958): Fundamentals of Palaeontology, Mollusca - Cephalopoda II, Ammonoidea (Ceratites and Ammonites). - pp. 1-359; Moscow [in Russian].

Mathews, A. A. L. (1929): The Lower Triassic cephalopod fauna of the Fort Douglas area, Utah. - Walker Mus. Mem. 1: $1-46$.

MoJsisoviCs, E. v. (1896): Beiträge zur Kenntnis der obertriadischen Cephalopoden-Faunen des Himalaya. - Denkschr. Akad. Wissensch. Wien 63: 573-701.

NAKAZAWA, K. \& BANDO, Y. (1968): Lower and Middle Triassic Ammonites from Portuguese Timor (Palaeontological Study of Portuguese Timor, 4). - Mem. Fac. Sci. Kyoto Univ., Ser. Geol. and Mineral. 34: 83-114.

Nichols, K. M. \& Silberling, N. J. (1979): Early Triassic (Smithian) ammonites of Paleoequatorial affinity from the Chulitna terrane, south central Alaska. - U.S. Geol. Surv., prof. pap. 1121: 1-5.

Noetling, F. (1904): Über Medlicottia WAAG. und Episageceras n. g. aus den permischen und triadischen Schichten Indiens. - N. Jb. Miner. Geol. Paläont. 19: 334-376.

NoETLing, F. (1905): Die asiatische Trias. - In: FrECH, F. (ed.): Lethaea geognostica: Handbuch der Erdgeschichte mit Abbildungen der für die Formationen bezeichnendsten Versteinerungen. - pp. 107-221 (Schweizerbart) Stuttgart.

OKuneVA, T. M. (1990): Triassic biostratigraphy of southern regions of the East USSR without the Primorye territory. In: Zakharov, Y. D., Belyaeva, G. V. \& Nikitina, A. P. (eds): New data on Palaeozoic and Mesozoic biostratigraphy of the south Far East. - pp. 125-136 (Far Eastern Branch of the USSR Academy of Sciences) Vladivostok.

Pakistani-Japanese Research Group (1985): Permian and Triassic systems in the Salt Range and Surghar Range, Pakistan. - In: NAKAZAWA, K. \& DiCKINS, J. M. (eds): The Tethys: her paleogeography and paleobiogeography from paleozoic to mesozoic. - pp. 221-312 (Tokai University Press) Tokyo.

POPOV, Y. (1961): Triassic ammonoids of northeastern USSR. - Transact. Sci. Res. Inst. Geol. Arctic (NIIGA) 79: 1179.

PoPOV, Y. (1962): Some Early Triassic ammonoids of northern Caucasia. - Transact. Acad. Sci. USSR 127: $176-184$. 
RENZ, C. \& RENZ, O. (1948): Eine untertriadische Ammonitenfauna von der griechischen Insel Chios. - Schweiz. Paläontol. Abh. 66: 1-98.

SAKAGAMI, S. (1955): Lower Triassic ammonites from Iwai, Orguno-Mura, Nishitamagun, Kwanto massif, Japan. - Sci. Rep. Tokyo Kyoiku Diagaku C 30: 131-140.

ShevyreV, A. A. (1968). Triassic ammonoidea from the southern part of the USSR. - Transact. Palaeontol. Inst., Nauka, Moscow 119: 1-272.

ShevyreV, A. A. (1990): Ammonoids and chronostratigraphy of the Triassic. - Trudy Paleontol. Inst., Akad. Nauk SSR 241: $1-179$.

SheVyreV, A. A. (1995): Triassic ammonites of northwestern Caucasus. - Trudy Paleontol. Inst. Akad. Nauk SSR 264: $1-174$.

Shigeta, Y. \& ZAKHARov, Y. (2009): Systematic paleontology: cephalopods. - In: SHIGETA, Y., ZAKHAROV, Y., MaedA, H. \& Popov, A. M. (eds): The Lower Triassic system in the Abrek Bay area, South Primorye, Russia. Nat. Mus. Nat. and Sci. Monogr. 38: 44-140; Tokyo.

Shigeta, Y. \& NGuYen, H. D. (2014): Systematic paleontology: cephalopods. - In: ShigetA, Y., KomAtsu, T., MAEKAWA, T. \& DANG, H. T. (ed.): Olenekian (Early Triassic) stratigraphy and fossil assemblages in northeastern Vietnam. - Nat. Mus. Nat. and Sci. Monogr. 45: 65-167; Tokyo.

Shigeta, Y., \& KumagaE, T. (2015). Churkites, a Trans-Panthalassic Early Triassic Ammonoid Genus from South Primorye, Russian Far East. - Paleontol. Res. 19 (3): 219-236.

Shigeta, Y., MAEDA, H. \& ZAKHAROV, Y. (2009): Biostratigraphy: ammonoid succession. - In: SHIGETA, Y., Zakharov, Y., MaedA, H. \& Popov, A.M. (ed.): The Lower Triassic system in the Abrek Bay area, South Primorye, Russia. - Nat. Mus. Nat. and Sci. Monogr. 38: 24-27; Tokyo.

SMith, J. P. (1927): Upper Triassic marine invertebrate faunas of North America. - U.S. Geol. Surv., prof. pap. 141: 1262.

SMITH, J. P. (1932): Lower Triassic ammonoids of North America. - U.S. Geol. Surv., prof. pap. 167: 1-199.

SPATH, L. F. (1929): Corrections of cephalopod nomenclature. - The Naturalist: 269-271.

SPATH, L. F. (1930): The Eotriassic invertebrate fauna of East Greenland. - Meddelelser om Grøland 83: 1-90.

SpATH, L. F. (1934): Part 4: The Ammonoidea of the Trias, Catalogue of the Fossil Cephalopoda in the British Museum (Natural History). - pp. 1-521 (Trustees British Museum) London.

Stephen, D.A., Bylund, K.G., BYBee, P.J. \& ReAm, W.J. (2010): Ammonoid beds in the Lower Triassic Thaynes Formation of western Utah, USA. - In: TANABE, K., ShIGETA, Y., SASAKI, T. \& HIRANO, H. (eds): Cephalopodspresent and past. - pp. 243-252; Tokyo.

Tong, J. N., ZAKhAROV, Y. D. \& WU, S. B. (2004): Early Triassic ammonoid succession in Chaohu, Anhui Province. Acta Palaeontol. Sinica 43: 192-204.

Tozer, E. T. (1961): Triassic stratigraphy and faunas, Queen Elizabeth Islands, Arctic Archipelago. - Geol. Surv. Canada Mem. 316: 1-116.

TOzER, E. T. (1981): Triassic Ammonoidea; classification, evolution and relationship with Permian and Jurassic forms. In: House, M. R. \& SEnIOR, J. R. (eds): The Ammonoidea. - pp. 65-100 (Academic Press, Syst. Assoc.) London.

TOzER, E. T. (1994): Canadian Triassic ammonoid faunas. - Geol. Surv. Canada Bull. 467: 1-663.

WAAGEN, W. (1887): Salt-Range fossils. Vol 1: productus limestone fossils. - Palaeontol. Indica 13: 1-72.

WAAGEN, W. (1895): Salt-Range fossils. Vol 2: Fossils from the Ceratite Formation. - Palaeontol. Indica 13: 1-323.

WANG, Y.G. \& HE, G.X. (1976): Triassic ammonoids from the Mount Jolmo Lungma region. A report of scientific expedition in the Mount Jolmo Lungma region (1966-1968), Palaeontology. - Science Press: 223-438; Peking.

WANNER, J. (1911): Triascephalopoden von Timor und Roti. - N. Jb. Miner. Geol. Paläont. 32: 177-196.

WANNER, J. (1913): Geologie von Westtimor. - Geol. Rundschau 4 (2): 136-150.

WARE, D., Bucher, H., Brayard, A., SchneEbeli-HermanN, E. \& Brühwiler, T. (2015): High-resolution biochronology and diversity dynamics of the Early Triassic ammonoid recovery: The Dienerian faunas of the Northern Indian Margin. - Palaeogeogr. Palaeoclimatol. Palaeoecol. 440: 363-373.

WAterhouse, J. B. (1996): The Early and Middle Triassic ammonoid succession of the Himalayas in western and central Nepal: Part 3. Late middle Scythian ammonoids. - Palaeontographica Abt. A 241: 101-167.

Weitschat, W. \& LEHMANN, U. (1978): Biostratigraphy of the uppermost part of the Smithian stage (Lower Triassic) at the Botneheia, W-Spitsbergen. - Mitt. Geol.-Palaeontol. Inst. Univ. Hamburg 48: 85-100.

Welter, O. A. (1922): Die ammoniten der Unteren Trias von Timor. - Paläontol. Timor 11: 83-160.

Westermann, G. E. G. (1966): Covariation and taxonomy of the Jurassic ammonite Sonninia adicra (Waagen). - N. Jb. Geol. Paläontol. Abh. 124: 289-312.

WHITE, C. A. (1880): Contributions to invertebrate paleontology, no. 5: Triassic fossils of south-eastern Idaho. - U.S. Geol. Surv. Territ., $12^{\text {th }}$ Ann. Rep. 1: 105-118.

ZAKHAROV, Y. D. (1968): Lower Triassic biostratigraphy and ammonoids of South Primorye (in Russian, original title translated). - pp. 1-175 (Nauka) Moskva.

ZAKHAROV, Y. D. \& ABNAVI, N. M. (2013): The ammonoid recovery after the end-Permian mass extinction: evidence from the Iran-Transcaucasia area, Siberia, Primorye, and Kazakhstan. - Acta Palaeont. Pol. 58: 127-147. 
ZaKharov, Y. D. \& Popov, A. M. (2014): Recovery of Brachiopod and Ammonoid Faunas Following the End-Permian Crisis: Additional Evidence from the Lower Triassic of the Russian Far East and Kazakhstan. - J. Earth Sci. 25 (1): $1-44$.

Zakharov, Y. D., Shigeta, Y., Popov, A. M., Buryi, G. I., Oleinikov, A. V., Dorukhovskaya, E. A. \& MikHALIK, T. M. (2002): Triassic ammonoid succession in South Primorye: 1. Lower Olenekian Hedenstroemia bosphorensis and Anasibirites nevolini Zones. - Albertiana 27: 42-64.

ZaKharov, Y. D., BondarenKo, L. G., SmyshlyaeVA, O. P. \& Popov, A. M. (2013): Late Smithian (Early Triassic) ammonoids from the Anasibirites nevolini Zone of South Primorye, Russian Far East. - New Mexico Mus. Nat. Hist. Sci. Bull. 61: 597-612.

ZitTeL, K. A. v. (1884): Handbuch der Palaeontologie. Cephalopoda. - pp. 239-522; Munich. 
Scale bars are $10 \mathrm{~mm}$ unless otherwise indicated.

Plate 1

Figs A-C. Kashmirites baidi BRÜHWILER \& BUCHER, 2012a. PIMUZ 36927. Kashmirites fauna, early Smithian.

Figs D-F. Kashmirites armatus (WAAGEN, 1895). PIMUZ 36928. Kashmirites fauna, early Smithian.

Figs G-I. Kashmirites armatus (WAAGEN, 1895). PIMUZ 36929. Kashmirites fauna, early Smithian.

Figs J-L. Kashmirites armatus (WAAGEN, 1895). PIMUZ 36930. Kashmirites fauna, early Smithian.

Figs M-O. Kashmirites armatus (WAAGEN, 1895). PIMUZ 36931. Kashmirites fauna, early Smithian.

Figs P-Q. Kashmirites armatus (WAAGEN, 1895). PIMUZ 36932. Kashmirites fauna, early Smithian.

Figs R-S. Kashmirites armatus (WAAGEN, 1895). PIMUZ 36933. Kashmirites fauna, early Smithian.

Fig. T. Kashmirites armatus (WAAGEN, 1895). Suture line of PIMUZ 36934 with scale bar representing 5 mm, at H = $6.4 \mathrm{~mm}$. Kashmirites fauna, early Smithian.

Figs U-W. Kashmirites cf. guangxiense BRAYARD \& BUCHER, 2008. PIMUZ 36935. Kashmirites fauna, early Smithian.

Figs X-Z. Kashmirites cf. guangxiense BRAYARD \& BUCHER, 2008. PIMUZ 36936, ×0.75. Kashmirites fauna, early Smithian. 
Plate 2

Fig. A. Kashmirites nivalis (DIENER, 1897). Suture line of PIMUZ 36937 with scale bar representing $5 \mathrm{~mm}$, at $\mathrm{H}=$ $10 \mathrm{~mm}$. Kashmirites fauna, early Smithian.

Figs B-D. Kashmirites nivalis (DIENER, 1897). PIMUZ 36938, ×0.75. Kashmirites fauna, early Smithian.

Figs E-F. Kashmirites nivalis (DIENER, 1897). PIMUZ 36939, $\times 0.75$. Kashmirites fauna, early Smithian.

Figs G-I. Kashmirites nivalis (DIENER, 1897). PIMUZ 36940, $\times 0.75$. Kashmirites fauna, early S mithian.

Figs J-L. Kashmirites nivalis (DIENER, 1897). PIMUZ 36941, $\times 0.75$. Kashmirites fauna, early Smithian.

Figs M-O. Kashmirites nivalis (DIENER, 1897). PIMUZ 36942, ×0.75. Kashmirites fauna, early Smithian.

Figs P-R. Kashmirites nivalis (DIENER, 1897). PIMUZ 36943, ×0.75. Kashmirites fauna, early Smithian.

Figs S-U Kashmirites nivalis (DIENER, 1897). PIMUZ 36944, $\times 0.75$. Kashmirites fauna, early Smithian.

Fig. V. Preflorianites radians CHAO, 1959. PIMUZ 36945. Owenites fauna, early Smithian. 
Plate 3

Figs A-C. Pseudoceltites multiplicatus (WAAGEN, 1895). PIMUZ 36946, $\times 0.75$. Owenites fauna, middle Smithian. Figs D-F. Pseudoceltites multiplicatus (WAAGEN, 1895). PIMUZ 36947, $\times 0.75$. Owenites fauna, middle Smithian. Figs G-I. Pseudoceltites multiplicatus (WAAGEN, 1895). PIMUZ 36948, $\times 0.75$. Owenites fauna, middle Smithian. Figs J-L. Pseudoceltites multiplicatus (WAAGEN, 1895). PIMUZ 36949, $\times 0.75$. Owenites fauna, middle Smithian. Figs M-O. Pseudoceltites multiplicatus (WAAGEN, 1895). PIMUZ 36950, $\times 0.75$. Owenites fauna, middle Smithian. Fig. P. $\quad$ Pseudoceltites multiplicatus (WAAGEN, 1895). PIMUZ 36951, $\times 0.75$. Owenites fauna, middle Smithian. Figs Q-S. Pseudoceltites multiplicatus (WAAGEN, 1895). PIMUZ 36952, $\times 0.75$. Owenites fauna, middle Smithian. Figs T-V. Pseudoceltites multiplicatus (WAAGEN, 1895). PIMUZ 36953, $\times 0.75$. Owenites fauna, middle Smithian. Fig. W. $\quad$ Pseudoceltites multiplicatus (WAAGEN, 1895). PIMUZ 36954, $\times 0.75$. Owenites fauna, middle Smithian. Figs X-Z. Pseudoceltites multiplicatus (WAAGEN, 1895). PIMUZ 36955, $\times 0.75$. Owenites fauna, middle Smithian. Fig. AA. Pseudoceltites multiplicatus (WAAGEN, 1895). PIMUZ 36956, $\times 0.75$. Owenites fauna, middle Smithian. Fig. AB. Pseudoceltites multiplicatus (WAAGEN, 1895). PIMUZ 36957, $\times 0.75$. Owenites fauna, middle Smithian. 
Figs A-C. $\quad$ Pseudoceltites multiplicatus (WAAGEN, 1895). PIMUZ 36958, ×0.75. Owenites fauna, middle Smithian. Figs D-F. $\quad$ Pseudoceltites multiplicatus (WAAGEN, 1895). PIMUZ 36959, $\times 0.75$. Owenites fauna, middle Smithian. Figs G-I. $\quad$ Pseudoceltites multiplicatus (WAAGEN, 1895). PIMUZ 36960, $\times 0.75$. Owenites fauna, middle Smithian. Figs J-L. $\quad$ Pseudoceltites multiplicatus (WAAGEN, 1895). PIMUZ 36961, ×0.75. Owenites fauna, middle Smithian. Figs M-O Pseudoceltites multiplicatus (WAAGEN, 1895). PIMUZ 36962, $\times 0.75$. Owenites fauna, middle Smithian. Figs P-R. $\quad$ Pseudoceltites densistriatus (WELTER, 1922). PIMUZ 36963, $\times 0.75$. Owenites fauna, middle Smithian. Figs S-V. Pseudoceltites densistriatus (WELTER, 1922). PIMUZ 36964, $\times 0.75$. Owenites fauna, middle Smithian. Figs W-Y. Pseudoceltites densistriatus (WELTER, 1922). PIMUZ 36965, $\times 0.75$. Owenites fauna, middle Smithian. Figs Z-AB. Pseudoceltites densistriatus (WELTER, 1922). PIMUZ 36966, $\times 0.75$. Owenites fauna, middle Smithian. Figs AC-AE. Pseudoceltites densistriatus (WELTER, 1922). PIMUZ 36967, $\times 0.75$. Owenites fauna, middle Smithian. Figs AF-AH. Pseudoceltites densistriatus (WELTER, 1922). PIMUZ 36968, $\times 0.75$. Owenites fauna, middle Smithian. Figs AI-AJ. Pseudoceltites densistriatus (WELTER, 1922). PIMUZ 36969, ×0.75. Owenites fauna, middle Smithian. 
Plate 5

Figs A-C. $\quad$ Nyalamites angustecostatus (WELTER, 1922). PIMUZ 36970. Owenites fauna, middle Smithian. Figs D-E. $\quad$ Nyalamites angustecostatus (WELTER, 1922). PIMUZ 36971. Owenites fauna, middle Smithian. Fig. F. Nyalamites angustecostatus (WELTER, 1922). PIMUZ 36972, X0.75. Owenites fauna, middle Smithian. Figs G-I. $\quad$ Nyalamites angustecostatus (WELTER, 1922). PIMUZ 36973. Owenites fauna, middle Smithian. Figs J-L. $\quad$ Nyalamites angustecostatus (WELTER, 1922). PIMUZ 36974. Owenites fauna, middle Smithian. Figs M-O. $\quad$ Nyalamites angustecostatus (WELTER, 1922). PIMUZ 36975. Owenites fauna, middle Smithian. Figs P-R. $\quad$ Nyalamites angustecostatus (WELTER, 1922). PIMUZ 36976. Owenites fauna, middle Smithian.

Figs $\mathrm{S}-\mathrm{T}$. Figs U-W. Figs $\mathrm{X}-\mathrm{Y}$. Figs $\mathrm{Z}-\mathrm{AB}$.

Figs AC-AE Figs AF-AH. Nyalamites angustecostatus (WELTER, 1922). PIMUZ 36977. Owenites fauna, middle Smithian. Nyalamites angustecostatus (WELTER, 1922). PIMUZ 36978. Owenites fauna, middle Smithian. Nyalamites angustecostatus (WELTER, 1922). PIMUZ 36979. Owenites fauna, middle Smithian.

Figs AI-AK. Nyalamites angustecostatus (WELTER, 1922). PIMUZ 36980. Owenites fauna, middle Smithian.

Figs AL-AN. Hanielites gracilus BRAYARD \& BUCHER, 2008. PIMUZ 36984. Owenites fauna, middle Smithian. Figs AO-AQ. Hanielites gracilus BRAYARD \& BUCHER, 2008. PIMUZ 36985. Owenites fauna, middle Smithian. Fig. AR. Hanielites gracilus BRAYARD \& BUCHER, 2008. PIMUZ 36986. Owenites fauna, middle Smithian. Figs AS-AT. Hanielites gracilus BRAYARD \& BUCHER, 2008. PIMUZ 36987. Owenites fauna, middle Smithian. Figs AU-AV. Hanielites gracilus BRAYARD \& BUCHER, 2008. PIMUZ 36988. Owenites fauna, middle Smithian. 
Plate 6

Figs A-C. Roopnarinites n. gen. paucesculptatum (WELTER, 1922). PIMUZ 36989. Owenites fauna, middle Smithian.

Figs D-F. Roopnarinites n. gen. paucesculptatum (WELTER, 1922). PIMUZ 36990. Owenites fauna, middle Smithian.

Figs G-I. Roopnarinites n. gen. paucesculptatum (WELTER, 1922). PIMUZ 36991. Owenites fauna, middle Smithian.

Figs J-L. Roopnarinites n. gen. paucesculptatum (WELTER, 1922). PIMUZ 36992. Owenites fauna, middle Smithian.

Figs M-O. Roopnarinites n. gen. paucesculptatum (WELTER, 1922). PIMUZ 36993. Owenites fauna, middle Smithian.

Figs P-R. Roopnarinites n. gen. paucesculptatum (WELTER, 1922). PIMUZ 36994. Owenites fauna, middle Smithian.

Figs S-U. Roopnarinites n. gen. paucesculptatum (WELTER, 1922). PIMUZ 36995. Owenites fauna, middle Smithian.

Fig. V. Roopnarinites n. gen. paucesculptatum (WELTER, 1922). Suture line of PIMUZ 36991 with scale bar representing $5 \mathrm{~mm}$, at $\mathrm{H}=11.7 \mathrm{~mm}$. Owenites fauna, middle Smithian.

Figs W-Y. $\quad$ Proptychitidae gen. et sp. indet. PIMUZ 36996. Owenites fauna, middle Smithian.

Fig. Z. Proptychitidae gen. et sp. indet. Suture line of PIMUZ 36996 with scale bar representing $5 \mathrm{~mm}$. Owenites fauna, middle Smithian.

Figs AA-AC. ?Tulongites sp. indet. PIMUZ 36997. Owenites fauna, middle Smithian.

Figs AD-AF ?Tulongites sp. indet. PIMUZ 36998. Owenites fauna, middle Smithian.

Fig. AG. ?Tulongites sp. indet. Suture line of PIMUZ 36997 with scale bar representing $5 \mathrm{~mm}$, at $\mathrm{H}=8 \mathrm{~mm}$. Owenites fauna, middle Smithian.

Figs AH-AI. Paraspidites bicarinatus n. sp. PIMUZ 36999, ×0.75. Kashmirites fauna, early Smithian.

Figs AJ-AL. Paraspidites bicarinatus n. sp., paratype. PIMUZ 37000, $\times 0.75$. Kashmirites fauna, early Smithian.

Fig. AM. Paraspidites bicarinatus n. sp. Suture line of PIMUZ 37000 with scale bar representing $5 \mathrm{~mm}$, at $\mathrm{H}=$ $13.3 \mathrm{~mm}$. Kashmirites fauna, early Smithian.

Figs AN-AP. Paraspidites bicarinatus n. sp., holotype. PIMUZ 37001, $\times 0.75$. Kashmirites fauna, early Smithian.

Figs AQ-AR. Paraspidites bicarinatus n. sp. PIMUZ 37002, $\times 0.75$. Kashmirites fauna, early Smithian.

Figs AS-AT. Paraspidites bicarinatus n. sp. PIMUZ 37003, ×0.75. Kashmirites fauna, early Smithian. 
Figs A-C. Galfettites simplicitatis BRAYARD \& BUCHER, 2008. PIMUZ 37004. Owenites fauna, middle Smithian.

Figs D-G. Galfettites simplicitatis BRAYARD \& BUCHER, 2008. PIMUZ 37005. Owenites fauna, middle Smithian.

Figs H-I. Galfettites simplicitatis BraYARD \& BUCHER, 2008, X0.5. PIMUZ 37006. Owenites fauna, middle Smithian.

Figs J-L. Galfettites omani BRÜHWILER \& BUCHER, 2012a. PIMUZ 37007, ×0.75. Anasibirites fauna, late Smithian.

Fig. M. Galfettites omani BRÜHWILER \& BUCHER, 2012a. Suture line of PIMUZ 37007 with scale bar representing $5 \mathrm{~mm}$, at $\mathrm{H}=32.7 \mathrm{~mm}$. Anasibirites fauna, late Smithian.

Figs N-P. $\quad$ Paranorites cf. ambiensis WAAGEN, 1895. PIMUZ 37008, $\times 0.75$. Kashmirites fauna, early Smithian.

Figs Q-S. $\quad$ Paranorites cf. ambiensis WAAGEN, 1895. PIMUZ 37010, $\times 0.5$. Kashmirites fauna, early Smithian.

Figs T-V. $\quad$ Paranorites cf. ambiensis WAAGEN, 1895. PIMUZ 37009, $\times 2$. Kashmirites fauna, early S mithian.

Figs W-Y. Vercherites cf. vercherei (WAAGEN, 1895). PIMUZ 37011, $\times 0.75$. Kashmirites fauna, early Smithian.

Figs Z-AB. Vercherites cf. vercherei (WAAGEN, 1895). PIMUZ 37012, $\times 0.75$. Kashmirites fauna, early Smithian.

Figs AC-AE. Urdyceras tulongensis BRÜHWILER, BUCHER \& GOUdEMAND, 2010b. PIMUZ 37013. Owenites fauna, middle Smithian.

Figs AF-AH. Urdyceras tulongensis BRÜHWILER, BUCHER \& GOUDEMAND, 2010b. PIMUZ 37014. Owenites fauna, middle Smithian.

Figs AI-AK. Urdyceras tulongensis BRÜHWILER, BUCHER \& GoUdEMAND, 2010b. PIMUZ 37015. Owenites fauna, middle Smithian.

Figs AL-AN. Urdyceras tulongensis BRÜHWILER, BUCHER \& GOUDEMAND, 2010b. PIMUZ 37016. Owenites fauna, middle Smithian.

Figs AO-AQ. Urdyceras tulongensis BRÜHWILER, BUCHER \& GOUdEMAND, 2010b. PIMUZ 37017. Owenites fauna, middle Smithian.

Figs AR-AU. Safraites simplex BRÜHWILER \& BUCHER, 2012a. PIMUZ 37018. Owenites fauna, middle Smithian. 
Plate 8

Figs A-C. Flemingites flemingianus (DE KONINCK, 1863). PIMUZ 37020, $\times 0.375$. Kashmirites fauna, early Smithian.

Figs D-F. Flemingites cf. planatus BRÜHWILER \& BUCHER, 2012b. PIMUZ 37021. Kashmirites fauna, early Smithian. 
Figs A-C. Flemingites pulcher WeLTER, 1922. PIMUZ 37022, ×0.4. Kashmirites fauna, early Smithian.

Figs D-F. Flemingites pulcher WELTER, 1922. PIMUZ 37023, ×0.4. Kashmirites fauna, early Smithian.

Fig. G. Flemingites pulcher WELTER, 1922. Suture line of PIMUZ 37024 with scale bar representing $5 \mathrm{~mm}$, at $\mathrm{H}=$ $31.4 \mathrm{~mm}$. Kashmirites fauna, early Smithian.

Figs H-I. Euflemingites guyerdetiformis (WELTER, 1922). PIMUZ 37025, $\times 0.75$. Kashmirites fauna, early Smithian.

Figs J-L. Euflemingites guyerdetiformis (WELTER, 1922). PIMUZ 37026, $\times 0.75$. Kashmirites fauna, early Smithian.

Fig. M. Euflemingites guyerdetiformis (WELTER, 1922). Suture line of PIMUZ 37027 with scale bar representing $5 \mathrm{~mm}$, at $\mathrm{H}=13.3 \mathrm{~mm}$. Kashmirites fauna, early Smithian.

Figs N-O. Pseudoflemingites timorensis SPATH, 1930. PIMUZ 37028. Kashmirites fauna, early Smithian.

Figs P-Q. Pseudoflemingites timorensis SPATH, 1930. PIMUZ 37029. Kashmirites fauna, early Smithian.

Fig. R. Pseudoflemingites timorensis SPATH, 1930. PIMUZ 37030. Kashmirites fauna, early Smithian.

Figs S-U. Pseudoflemingites timorensis SPATH, 1930. PIMUZ 37031, $\times 0.75$. Kashmirites fauna, early Smithian.

Fig. V. Pseudoflemingites timorensis SPATH, 1930. PIMUZ 37032. Kashmirites fauna, early Smithian. 
Figs A-C. Rohillites rohilla DIENER, 1897. PIMUZ 37033. Kashmirites fauna, early Smithian.

Figs D-F. Rohillites rohilla DIENER, 1897. PIMUZ 37034. Kashmirites fauna, early Smithian.

Figs G-I. Rohillites rohilla DIENER, 1897. PIMUZ 37035. Kashmirites fauna, early Smithian.

Figs J-L. Rohillites rohilla DIENER, 1897. PIMUZ 37036, ×2. Kashmirites fauna, early Smithian.

Fig. M. Rohillites rohilla DIENER, 1897. Suture line of PIMUZ 37035 with scale bar representing $5 \mathrm{~mm}$, at $\mathrm{H}=$ $15.6 \mathrm{~mm}$. Kashmirites fauna, early Smithian.

Fig. N. $\quad$ Rohillites rohilla DIENER, 1897. PIMUZ 37037. Kashmirites fauna, early Smithian.

Figs O-P. Rohillites rohilla DIENER, 1897. PIMUZ 37038. Kashmirites fauna, early Smithian.

Figs Q-S. Flemingites lidakensis n. sp., paratype. PIMUZ 37039, $\times 0.75$. Kashmirites fauna, early Smithian.

Figs T-V. Flemingites lidakensis n. sp., holotype. PIMUZ 37040, $\times 0.75$. Kashmirites fauna, early Smithian. 
Figs A-C. Subflemingites involutus (WELTER, 1922). PIMUZ 37041. Kashmirites fauna, early Smithian. Fig. D. $\quad$ Subflemingites involutus (WELTER, 1922). PIMUZ 37042. Kashmirites fauna, early Smithian. Figs E-G. Subflemingites involutus (WELTER, 1922). PIMUZ 37043. Kashmirites fauna, early Smithian. Figs H-J. Subflemingites involutus (WELTER, 1922). PIMUZ 37044. Kashmirites fauna, early Smithian. Figs K-L. Subflemingites bihatiense n. sp., paratype. PIMUZ 37045. Owenites fauna, middle Smithian.

Fig. M. Subflemingites bihatiense n. sp., holotype. PIMUZ 37046. Owenites fauna, middle Smithian.

Figs N-P. ?Subflemingites sp. indet. PIMUZ 37047. Owenites fauna, middle Smithian.

Fig. Q. $\quad$ ?Subflemingites sp. indet. Suture line of PIMUZ 37047 with scale bar representing $5 \mathrm{~mm}$, at $\mathrm{H}=21.7 \mathrm{~mm}$. Owenites fauna, middle Smithian. 
Figs A-C. Anaxenaspis orientale DIENER, 1895. PIMUZ 37048, ×0.5. Owenites fauna, middle Smithian. Fig. D. Anaxenaspis orientale DIENER, 1895. PIMUZ 37049, ×0.5. Owenites fauna, middle Smithian. Fig. E. $\quad$ Anaxenaspis orientale DIENER, 1895. PIMUZ 37050. Owenites fauna, middle Smithian.

Fig. F. Anaxenaspis orientale DIENER, 1895. PIMUZ 37051, $\times 0.5$. Owenites fauna, middle Smithian.

Fig. G. Anaxenaspis orientale DIENER, 1895. Suture line of PIMUZ 37052 with scale bar representing $5 \mathrm{~mm}$, at $\mathrm{H}=$ $23.1 \mathrm{~mm}$. Owenites fauna, middle Smithian.

Figs H-J. Anaxenaspis orientale DIENER, 1895. PIMUZ 37052, ×0.5. Owenites fauna, middle Smithian.

Fig. K. Anaxenaspis orientale DIENER, 1895. PIMUZ 37053, $\times 0.5$. Owenites fauna, middle Smithian.

Figs L-N. Anaxenaspis orientale DIENER, 1895. PIMUZ 37054, $\times 0.5$. Owenites fauna, middle Smithian.

Fig. O. Anaxenaspis orientale DIENER, 1895. Suture line of PIMUZ 37048 with scale bar representing $5 \mathrm{~mm}$, at $\mathrm{H}=$ $28.7 \mathrm{~mm}$. Owenites fauna, middle Smithian.

Fig. P. Anaxenaspis orientale DIENER, 1895. Suture line of PIMUZ 37055 with scale bar representing $5 \mathrm{~mm}$. Owenites fauna, middle Smithian. 
Figs A-C. Hochuliites retrocostatus BRÜHWILER et al., 2012c. PIMUZ 37056, $\times 0.75$. Owenites fauna, middle Smithian. Figs D-F. Hochuliites retrocostatus BRÜHWILER et al., 2012c. PIMUZ 37057, ×0.75. Owenites fauna, middle Smithian. Fig. G. Hochuliites retrocostatus BRÜHWILER et al., 2012c. Suture line of PIMUZ 37056 with scale bar representing $5 \mathrm{~mm}$, at $\mathrm{H}=24.3 \mathrm{~mm}$. Owenites fauna, middle Smithian.

Figs H-J. Anaxenaspis compressus (BRÜHWILER et al., 2010b). PIMUZ 37058. Owenites fauna, middle Smithian.

Fig. K. Anaxenaspis compressus (BRÜHWILER et al., 2010b). Suture line of PIMUZ 37059 with scale bar representing $5 \mathrm{~mm}$, at $\mathrm{H}=20.8 \mathrm{~mm}$. Owenites fauna, middle Smithian.

Figs L-N. Anaxenaspis compressus (BRÜHWILER et al., 2010b). PIMUZ 37059. Owenites fauna, middle Smithian. 
Figs A-C. Baidites tenue (WELTER, 1922). PIMUZ 37060, ×0.5. Kashmirites fauna, early Smithian.

Figs D-F. Baidites tenue (WELTER, 1922). PIMUZ 37061, ×0.5. Kashmirites fauna, early Smithian.

Figs G-I. Baidites tenue (WELTER, 1922). PIMUZ 37062, ×0.5. Kashmirites fauna, early Smithian.

Fig. J. Baidites tenue (WELTER, 1922). Suture line of PIMUZ 37061 with scale bar representing $5 \mathrm{~mm}$, at $\mathrm{H}=$ $11.8 \mathrm{~mm}$. Kashmirites fauna, early Smithian.

Figs K-M. Baidites crassecostatum (WELTER, 1922). PIMUZ 37063, ×0.5. Kashmirites fauna, early Smithian.

Figs N-P. Baidites crassecostatum (WELTER, 1922). PIMUZ 37064, $\times 0.5$. Kashmirites fauna, early Smithian.

Figs Q-S. Baidites crassecostatum (WELTER, 1922). PIMUZ 37065, $\times 0.5$. Kashmirites fauna, early Smithian.

Figs T-V. Baidites crassecostatum (WELTER, 1922). PIMUZ 37066, $\times 0.5$. Kashmirites fauna, early Smithian.

Fig. W. Baidites crassecostatum (WELTER, 1922). PIMUZ 37067, $\times 0.5$. Kashmirites fauna, early Smithian.

Figs X-Z. Baidites crassecostatum (WELTER, 1922). PIMUZ 37068, $\times 0.5$. Kashmirites fauna, early Smithian. 
Plate 15

Fig. A. Baidites obesus n. sp. Suture line of PIMUZ 37069 with scale bar representing $5 \mathrm{~mm}$, at $\mathrm{H}=25.5 \mathrm{~mm}$. Kashmirites fauna, early Smithian.

Figs B-D. Baidites obesus n. sp., paratype. PIMUZ 37069, ×0.6. Kashmirites fauna, early Smithian.

Fig. E. $\quad$ Baidites obesus n. sp. PIMUZ 37070, $\times 0.6$. Kashmirites fauna, early Smithian.

Figs F-H. Baidites obesus n. sp., holotype. PIMUZ 37071, ×0.6. Kashmirites fauna, early Smithian.

Figs I-K. Genus gen. indet. A. PIMUZ 37072, ×0.6. Kashmirites fauna, early Smithian. 
Figs A-D. Dieneroceras dieneri (HyATt \& SMITH, 1905). PIMUZ 37073. Owenites fauna, middle Smithian. Figs E-H. Dieneroceras dieneri (HYATT \& SMITH, 1905). PIMUZ 37074. Owenites fauna, middle Smithian. Figs I-K. Dieneroceras dieneri (HYATT \& SMITH, 1905). PIMUZ 37075. Owenites fauna, middle Smithian. Figs L-N. Dieneroceras dieneri (HYATT \& SMITH, 1905). PIMUZ 37076. Owenites fauna, middle Smithian. Figs O-R. Dieneroceras dieneri (HYATT \& SMITH, 1905). PIMUZ 37077. Owenites fauna, middle Smithian. Fig. S. Dieneroceras knechti (HYATT \& SMITH, 1905). PIMUZ 37078. Owenites fauna, middle Smithian. Figs T-V. Dieneroceras knechti (HYATT \& SMITH, 1905). PIMUZ 37079. Owenites fauna, middle Smithian. Fig. W. Dieneroceras cf. tientungense CHAO, 1959. PIMUZ 37080. Kashmirites fauna, early Smithian. Figs X-Y. Dieneroceras cf. tientungense CHAO, 1959. PIMUZ 37081. Kashmirites fauna, early Smithian. Fig. Z. Dieneroceras cf. tientungense CHAO, 1959. PIMUZ 37082. Kashmirites fauna, early Smithian. Figs AA-AC. Dieneroceras cf. tientungense CHAO, 1959. PIMUZ 37083. Kashmirites fauna, early Smithian. Figs AD-AF. Dieneroceras cf. tientungense CHAO, 1959. PIMUZ 37084. Kashmirites fauna, early Smithian. Figs AG-AH. Dieneroceras cf. tientungense CHAO, 1959. PIMUZ 37085. Kashmirites fauna, early Smithian.

Fig. AI. Dieneroceras cf. tientungense CHAO, 1959. Suture line of PIMUZ 37085 with scale bar representing $5 \mathrm{~mm}$, at $\mathrm{H}=5.2 \mathrm{~mm}$. Kashmirites fauna, early Smithian.

Figs AJ-AK. ?Omanites sp. indet. PIMUZ 37086. Owenites fauna, middle Smithian. 
Figs A-C. $\quad$ Owenites sp. indet. PIMUZ 37087. Owenites fauna, middle Smithian.

Figs D-F. $\quad$ Owenites sp. indet. PIMUZ 37088. Owenites fauna, middle Smithian.

Figs G-I. Owenites sp. indet. PIMUZ 37089. Owenites fauna, middle Smithian.

Figs J-L. Owenites sp. indet. PIMUZ 37090. Owenites fauna, middle Smithian.

Figs M-O. Owenites sp. indet. PIMUZ 37091. Owenites fauna, middle Smithian.

Figs P-R. $\quad$ Owenites sp. indet. PIMUZ 37092. Owenites fauna, middle Smithian.

Figs S-U. $\quad$ Owenites sp. indet. PIMUZ 37093. Owenites fauna, middle Smithian.

Figs V-X. Owenites sp. indet. PIMUZ 37094. Owenites fauna, middle Smithian.

Figs Y-AA. Owenites sp. indet. PIMUZ 37095. Owenites fauna, middle Smithian.

Figs AB-AD. Owenites koeneni HyATT \& SMITH, 1905. PIMUZ 37096. Owenites fauna, middle Smithian.

Figs AE-AG. Owenites koeneni HYATT \& SMITH, 1905. PIMUZ 37098. Owenites fauna, middle Smithian.

Fig. AH. Owenites koeneni HyATt \& SMITH, 1905. Suture line of PIMUZ 37097 with scale bar representing $5 \mathrm{~mm}$, at $\mathrm{H}=12 \mathrm{~mm}$. Owenites fauna, middle Smithian.

Figs AI-AJ. Owenites koeneni HYATT \& SMITH, 1905. PIMUZ 37099. Owenites fauna, middle Smithian.

Figs AK-AM. Owenites koeneni HYATT \& SMITH, 1905. PIMUZ 37100. Owenites fauna, middle Smithian.

Figs AN-AP. Owenites koeneni HYATT \& SMITH, 1905. PIMUZ 37101. Owenites fauna, middle Smithian.

Fig. AQ. Owenites koeneni HYATT \& SMITH, 1905. PIMUZ 37102. Owenites fauna, middle Smithian.

Figs AR-AT. Owenites koeneni HYATT \& SMITH, 1905. PIMUZ 37103. Owenites fauna, middle Smithian.

Figs AU-AW. Owenites koeneni HYATT \& SMITH, 1905. PIMUZ 37104. Owenites fauna, middle Smithian. 
Figs A-C. $\quad$ Owenites egrediens WelteR, 1922. PIMUZ 37105. Owenites fauna, middle Smithian. Figs D-E. $\quad$ Owenites egrediens WELTER, 1922. PIMUZ 37106. Owenites fauna, middle Smithian. Figs F-H. Owenites egrediens WELTER, 1922. PIMUZ 37107. Owenites fauna, middle Smithian. Figs I-K. Owenites egrediens WELTER, 1922. PIMUZ 37108. Owenites fauna, middle Smithian. Figs L-N. Owenites egrediens WELTER, 1922. PIMUZ 37109. Owenites fauna, middle Smithian. Figs O-R. $\quad$ Owenites egrediens WELTER, 1922. PIMUZ 37110. Owenites fauna, middle Smithian. Figs S-U. Owenites egrediens WELTER, 1922. PIMUZ 37111. Owenites fauna, middle Smithian. Figs V-X. Owenites egrediens WELTER, 1922. PIMUZ 37112. Owenites fauna, middle Smithian. Figs Y-AA. Owenites egrediens WELTER, 1922. PIMUZ 37113. Owenites fauna, middle Smithian. Figs AB-AD. Owenites egrediens WELTER, 1922. PIMUZ 37114. Owenites fauna, middle Smithian. 
Figs A-D. Owenites simplex WeLTER, 1922. PIMUZ 37116. Owenites fauna, middle Smithian. Figs E-G. $\quad$ Owenites simplex WELTER, 1922. PIMUZ 37117. Owenites fauna, middle Smithian. Figs H-J. Owenites simplex WeLTER, 1922. PIMUZ 37118. Owenites fauna, middle Smithian. Figs K-L. Owenites simplex WELTER, 1922. PIMUZ 37119. Owenites fauna, middle Smithian. Figs M-O. Owenites simplex WELTER, 1922. PIMUZ 37120. Owenites fauna, middle Smithian. Fig. P. Owenites simplex WELTER, 1922. PIMUZ 37121. Owenites fauna, middle Smithian. Figs Q-S. $\quad$ Owenites simplex WELTER, 1922. PIMUZ 37122. Owenites fauna, middle Smithian. Figs T-V. Owenites simplex WELTER, 1922. PIMUZ 37123. Owenites fauna, middle Smithian. Figs W-Z. $\quad$ Owenites simplex WELTER, 1922. PIMUZ 37124. Owenites fauna, middle Smithian. Figs AA-AC. Owenites simplex WELTER, 1922. PIMUZ 37125. Owenites fauna, middle Smithian. Figs AD-AF. Owenites simplex WELTER, 1922. PIMUZ 37126. Owenites fauna, middle Smithian. Figs AG-AJ. Owenites simplex WELTER, 1922. PIMUZ 37127. Owenites fauna, middle Smithian. Figs AK-AM. Owenites simplex WeLTER, 1922. PIMUZ 37128. Owenites fauna, middle Smithian. 
Figs A-C. $\quad$ Steckites brevus WeLTER, 1922. PIMUZ 37129. Owenites fauna, middle Smithian. Figs D-F. $\quad$ Steckites brevus WELTER, 1922. PIMUZ 37130. Owenites fauna, middle Smithian. Figs G-I. $\quad$ Steckites brevus WELTER, 1922. PIMUZ 37131. Owenites fauna, middle Smithian. Figs J-K. Steckites brevus WELTER, 1922. PIMUZ 37132. Owenites fauna, middle Smithian. Fig. L. $\quad$ Steckites brevus WELTER, 1922. PIMUZ 37133. Owenites fauna, middle Smithian. Fig. M. Steckites brevus WELTER, 1922. PIMUZ 37134. Owenites fauna, middle Smithian. Figs N-Q. $\quad$ Steckites brevus WELTER, 1922. PIMUZ 37135. Owenites fauna, middle Smithian. Figs R-S. $\quad$ Steckites brevus WELTER, 1922. PIMUZ 37136. Owenites fauna, middle Smithian. Figs T-V. $\quad$ Steckites brevus WELTER, 1922. PIMUZ 37137. Owenites fauna, middle Smithian. Figs W-Y. $\quad$ Steckites brevus WELTER, 1922. PIMUZ 37138. Owenites fauna, middle Smithian. Figs Z-AA. Steckites brevus WELTER, 1922. PIMUZ 37139. Owenites fauna, middle Smithian. Figs AB-AD. Steckites brevus WELTER, 1922. PIMUZ 37140. Owenites fauna, middle Smithian. Figs AE-AG. Steckites brevus WELTER, 1922. PIMUZ 37141. Owenites fauna, middle Smithian. Figs AH-AJ. Steckites brevus WELTER, 1922. PIMUZ 37145. Owenites fauna, middle Smithian. Figs AK-AN. Steckites brevus WELTER, 1922. PIMUZ 37142. Owenites fauna, middle Smithian. Figs AO-AQ. Steckites brevus WELTER, 1922. PIMUZ 37143. Owenites fauna, middle Smithian. Figs AR-AT. Steckites brevus WELTER, 1922. PIMUZ 37144. Owenites fauna, middle Smithian.

Fig. AU. Steckites brevus WELTER, 1922. Suture line of PIMUZ 37138 with scale bar representing $5 \mathrm{~mm}$, at $\mathrm{H}=$ $8.3 \mathrm{~mm}$. Owenites fauna, middle Smithian. 
Figs A-C. Juvenites spathi (FrEBOLD, 1930). PIMUZ 37146. Owenites fauna, middle Smithian. Figs D-F. Juvenites spathi (FREBOLD, 1930). PIMUZ 37147. Owenites fauna, middle Smithian. Figs G-I. Juvenites spathi (FrEBOLD, 1930). PIMUZ 37148. Owenites fauna, middle Smithian. Figs J-L. Juvenites spathi (FREBOLD, 1930). PIMUZ 37149. Owenites fauna, middle Smithian. Figs M-N. Juvenites spathi (FREBOLD, 1930). PIMUZ 37150. Owenites fauna, middle Smithian. Figs O-Q. Juvenites spathi (FREBOLD, 1930). PIMUZ 37151, $\times 0.75$. Owenites fauna, middle Smithian. Figs R-T. Juvenites spathi (FREBOLD, 1930). PIMUZ 37152, $\times 0.75$. Owenites fauna, middle Smithian. Figs U-W. Juvenites spathi (FREBOLD, 1930). PIMUZ 37153. Owenites fauna, middle Smithian. Figs X-Z. Juvenites spathi (FrEBOLD, 1930). PIMUZ 37154. Owenites fauna, middle Smithian. Figs AA-AB. Juvenites spathi (FrEBOLD, 1930). PIMUZ 37155. Owenites fauna, middle Smithian. 
Figs A-D. Juvenites septentrionalis SмITH, 1932. PIMUZ 37156. Owenites fauna, middle Smithian.

Figs E-G. Juvenites septentrionalis SMITH, 1932. PIMUZ 37157. Owenites fauna, middle Smithian.

Figs H-K. Juvenites septentrionalis SMITH, 1932. PIMUZ 37158. Owenites fauna, middle Smithian.

Figs L-N. Juvenites septentrionalis SMITH, 1932. PIMUZ 37159. Owenites fauna, middle Smithian.

Figs O-Q. Juvenites septentrionalis SмITH, 1932. PIMUZ 37160. Owenites fauna, middle Smithian.

Figs R-T. Juvenites cf. septentrionalis SMITH, 1932. PIMUZ 37161. Owenites fauna, middle Smithian.

Fig. U. Subinyoites cf. punjabiensis BRÜHWILER \& BUCHER, 2012b. Suture line of PIMUZ 37162 with scale bar representing $5 \mathrm{~mm}$, at $\mathrm{H}=19 \mathrm{~mm}$. Owenites fauna, middle Smithian.

Figs V-X. $\quad$ Subinyoites cf. punjabiensis BRÜHWILER \& BUCHER, 2012b. PIMUZ 37162. Owenites fauna, middle Smithian.

Figs Y-AA. Subvishnuites welteri SPATH, 1930. PIMUZ 37163. Owenites fauna, middle Smithian.

Figs AB-AD. Subvishnuites welteri SPATH, 1930. PIMUZ 37164. Owenites fauna, middle Smithian.

Figs AE-AG. Subvishnuites welteri SPATH, 1930. PIMUZ 37165, ×0.75. Owenites fauna, middle Smithian.

Figs AH-AJ. Subvishnuites welteri SPATH, 1930. PIMUZ 37166. Owenites fauna, middle Smithian.

Figs AK-AM. Subvishnuites welteri SPATH, 1930. PIMUZ 37167. Owenites fauna, middle Smithian.

Figs AN-AP. Subvishnuites welteri SPATH, 1930. PIMUZ 37168. Owenites fauna, middle Smithian.

Figs AQ-AS. Subvishnuites welteri SPATH, 1930. PIMUZ 37169, $\times 0.75$. Owenites fauna, middle Smithian.

Figs AT-AU. Subvishnuites cf. posterus BRÜHWILER et al., 2012c. PIMUZ 37170. Anasibirites fauna, late Smithian. 
Figs A-C. Truempyceras pluriformis (GUEX, 1978). PIMUZ 37171, $\times 0.5$. Owenites fauna, middle Smithian. Figs D-F. Truempyceras pluriformis (GUEX, 1978). PIMUZ 37172, $\times 0.5$. Owenites fauna, middle Smithian. Figs G-H. Truempyceras pluriformis (GUEX, 1978). PIMUZ 37173, $\times 0.5$. Owenites fauna, middle Smithian. Fig. I. Truempyceras pluriformis (GUEX, 1978). PIMUZ 37174, $\times 0.5$. Owenites fauna, middle Smithian.

Figs J-L. $\quad$ Truempyceras pluriformis (GUEX, 1978). PIMUZ 37175, $\times 0.5$. Owenites fauna, middle Smithian.

Figs M-O. Truempyceras pluriformis (GUEX, 1978). PIMUZ 37176, $\times 0.5$. Owenites fauna, middle Smithian.

Figs P-R. Truempyceras pluriformis (GUEX, 1978). PIMUZ 37177, $\times 0.5$. Owenites fauna, middle Smithian.

Figs S-U. Truempyceras pluriformis (GUEX, 1978). PIMUZ 37178, $\times 0.5$. Owenites fauna, middle Smithian.

Fig. V. $\quad$ Truempyceras pluriformis (GUEX, 1978). Suture line of PIMUZ 37179 with scale bar representing 5 mm, at $\mathrm{H}=15.2 \mathrm{~mm}$. Owenites fauna, middle Smithian.

Figs W-Y. Truempyceras pluriformis (GUEX, 1978). PIMUZ 37179, $\times 0.5$. Owenites fauna, middle Smithian.

Fig. Z. Truempyceras pluriformis (GUEX, 1978). PIMUZ 37180, $\times 0.5$. Owenites fauna, middle Smithian.

Figs AA-AC. Truempyceras cf. compressum BRÜHWILER et al., 2012c. PIMUZ 37181, ×0.5. Owenites fauna, middle Smithian.

Figs AD-AF. Truempyceras compressum BRÜHWILER et al., 2012c. PIMUZ 37182, ×0.5. Owenites fauna, middle Smithian.

Figs AG-AJ. Truempyceras compressum BRÜHWILER et al., 2012c. PIMUZ 37183, ×0.5. Owenites fauna, middle Smithian.

Figs AK-AM. Truempyceras compressum BRÜHWILER et al., 2012c. PIMUZ 37184, ×0.5. Owenites fauna, middle Smithian.

Fig. AN. Truempyceras compressum BRÜHWILER et al., 2012c. PIMUZ 37186, ×0.5. Owenites fauna, middle Smithian.

Fig. AO. Truempyceras compressum BRÜHWILER et al., 2012c. Suture line of PIMUZ 37187 with scale bar representing $5 \mathrm{~mm}$, at $\mathrm{H}=14.8 \mathrm{~mm}$. Owenites fauna, middle Smithian.

Figs AP-AR. Truempyceras compressum BRÜHWILER et al., 2012c. PIMUZ 37188, ×0.5. Owenites fauna, middle Smithian.

Fig. AS. Truempyceras compressum BRÜHWILER et al., 2012c. PIMUZ 37189, ×0.5. Owenites fauna, middle Smithian.

Fig. AT. Truempyceras compressum BRÜHWILER et al., 2012c. PIMUZ 37190, ×0.5. Owenites fauna, middle Smithian. 
Plate 24

Figs A-B. Brayardites compressus BRÜHWILER et al., 2010b. PIMUZ 37191, ×0.5. Owenites fauna, middle Smithian.

Figs C-E. Brayardites compressus BRÜHWILER et al., 2010b. PIMUZ 37192, ×0.5. Owenites fauna, middle Smithian.

Figs F-H. Brayardites compressus BRÜHWILER et al., 2010b. PIMUZ 37193, ×0.5. Owenites fauna, middle Smithian.

Figs I-K. Brayardites compressus BRÜHWILER et al., 2010b. PIMUZ 37194, ×0.5. Owenites fauna, middle Smithian.

Figs L-N. $\quad$ Brayardites compressus BRÜHWILER et al., 2010b. PIMUZ 37195, ×0.5. Owenites fauna, middle Smithian.

Figs O-P. $\quad$ Brayardites compressus BRÜHWILER et al., 2010b. PIMUZ 37196, ×0.5. Owenites fauna, middle Smithian.

Fig. Q. $\quad$ Brayardites compressus BRÜHWILER et al., 2010b. Suture line of PIMUZ 37197 with scale bar representing $5 \mathrm{~mm}$, at $\mathrm{H}=29.9 \mathrm{~mm}$. Owenites fauna, middle Smithian.

Figs R-T. Brayardites compressus BRÜHWILER et al., 2010b. PIMUZ 37198, $\times 0.5$. Owenites fauna, middle Smithian. 
Figs A-C. Brayardites malayicum (WeLTER, 1922). PIMUZ 37199, $\times 0.5$. Owenites fauna, middle Smithian. Figs D-F. Brayardites malayicum (WELTER, 1922). PIMUZ 37200, $\times 0.5$. Owenites fauna, middle Smithian. Figs G-H. Brayardites malayicum (WELTER, 1922). PIMUZ 37201, $\times 0.5$. Owenites fauna, middle Smithian. Figs I-K. Brayardites malayicum (WeLTER, 1922). PIMUZ 37202, $\times 0.5$. Owenites fauna, middle Smithian. Figs L-M. Brayardites malayicum (WELTER, 1922). PIMUZ 37203, $\times 0.5$. Owenites fauna, middle Smithian. Figs N-P. Brayardites malayicum (WELTER, 1922). PIMUZ 37204, $\times 0.5$. Owenites fauna, middle Smithian. Figs Q-S. Brayardites malayicum (WELTER, 1922). PIMUZ 37205, $\times 0.5$. Owenites fauna, middle Smithian. Figs T-V. Brayardites cf. malayicum (WeLTER, 1922). PIMUZ 37206, $\times 0.5$. Owenites fauna, middle Smithian. Figs W-Y. Brayardites cf. malayicum (WeLTER, 1922). PIMUZ 37207, $\times 0.5$. Owenites fauna, middle Smithian. Figs Z-AA. Brayardites cf. malayicum (WELTER, 1922). PIMUZ 37208, ×0.5. Owenites fauna, middle Smithian. 
Plate 26

Figs A-C. ? Nammalites cf. pilatoides (GUEX, 1978). PIMUZ 37209, X1.5. Owenites fauna, middle Smithian.

Figs D-F. ? Nammalites cf. pilatoides (GUEX, 1978). PIMUZ 37210, X1.5. Owenites fauna, middle Smithian.

Fig. G. ? Nammalites cf. pilatoides (GUEX, 1978). Suture line of PIMUZ 37209 with scale bar representing $5 \mathrm{~mm}$, at $\mathrm{H}=8 \mathrm{~mm}$. Owenites fauna, middle Smithian.

Figs H-I. ? Nammalites cf. pilatoides (GUEX, 1978). PIMUZ 37211. Owenites fauna, middle Smithian.

Figs J-L. Churkites warei n. sp., paratype. PIMUZ 37212. Owenites fauna, middle Smithian.

Figs M-O. Churkites warei n. sp., holotype. PIMUZ 37213. Owenites fauna, middle Smithian. 
Figs A-C. $\quad$ Prionites tuberculatus WAAGEN, 1895. PIMUZ 37214, $\times 0.5$. Owenites fauna, middle Smithian.

Figs D-F. $\quad$ Prionites tuberculatus WAAGEN, 1895. PIMUZ 37215, $\times 0.5$. Owenites fauna, middle Smithian.

Figs G-I. $\quad$ Prionites tuberculatus WAAGEN, 1895. PIMUZ 37216, $\times 0.5$. Owenites fauna, middle Smithian.

Figs J-L. $\quad$ Prionites tuberculatus WAAGEN, 1895. PIMUZ 37217, $\times 0.5$. Owenites fauna, middle Smithian.

Figs M-O. $\quad$ Prionites tuberculatus WAAGEN, 1895. PIMUZ 37218, $\times 0.5$. Owenites fauna, middle Smithian.

Figs P-R. $\quad$ Prionites tuberculatus WAAGEN, 1895. PIMUZ 37219, $\times 0.5$. Owenites fauna, middle Smithian.

Figs S-U. Prionites involutus BRÜHWILER et al., 2010b. PIMUZ 37220, $\times 0.5$. Owenites fauna, middle Smithian.

Figs V-X. Prionites involutus BRÜHWILER et al., 2010b. PIMUZ 37221, $\times 0.5$. Owenites fauna, middle Smithian.

Fig. Y. $\quad$ Prionites involutus BRÜHWILER et al., 2010b. Suture line of PIMUZ 37221 with scale bar representing $5 \mathrm{~mm}$, at $\mathrm{H}=24.5 \mathrm{~mm}$. Owenites fauna, middle Smithian.

Figs Z-AB. Prionites nammalensis BRÜHWILER \& BUCHER, 2012b. PIMUZ 37222, ×0.5. Owenites fauna, middle Smithian.

Figs AC-AD. Stephanites superbus WAAGEN, 1895. PIMUZ 37223. Owenites fauna, middle Smithian. 
Figs A-C. Wasatchites distractus (WAAGEN, 1895). PIMUZ 37224. Anasibirites fauna, late Smithian.

Figs D-F. Wasatchites distractus (WAAGEN, 1895). PIMUZ 37225. Anasibirites fauna, late Smithian.

Figs G-H. Wasatchites distractus (WAAGEN, 1895). PIMUZ 37226. Anasibirites fauna, late Smithian.

Figs I-K. ?Anasibirites sp. indet. PIMUZ 37227, ×0.75. Anasibirites fauna, late Smithian.

Figs L-N. ? Anasibirites sp. indet. PIMUZ 37228. Anasibirites fauna, late Smithian.

Fig. O. Prionitidae gen. indet. PIMUZ 37229. Anasibirites fauna, late Smithian.

Fig. P. Arctoprionites resseri (MATHEWS, 1929). PIMUZ 37230, $\times 0.75$. Anasibirites fauna, late Smithian.

Fig. Q. Arctoprionites resseri (MATHEWS, 1929). PIMUZ 37231, $\times 0.75$. Anasibirites fauna, late Smithian.

Figs R-S. Arctoprionites resseri (MATHEWS, 1929). PIMUZ 37232. Anasibirites fauna, late Smithian.

Figs T-U. Arctoprionites resseri (MATHEWS, 1929). PIMUZ 37233, $\times 0.75$. Anasibirites fauna, late Smithian. 
Figs A-B. Hemiprionites typus (WAAGEN, 1895) with depression near venter. PIMUZ 37234, $\times 0.75$. Anasibirites fauna, late Smithian.

Figs C-D. Hemiprionites typus (WAAGEN, 1895) with depression near venter. PIMUZ 37235, $\times 0.75$. Anasibirites fauna, late Smithian.

Figs E-F. Hemiprionites typus (WAAGEN, 1895) with depression near venter. PIMUZ 37236, $\times 0.75$. Anasibirites fauna, late Smithian.

Figs G-I. Hemiprionites typus (WAAGEN, 1895) with depression near venter. PIMUZ 37237, ×0.75. Anasibirites fauna, late Smithian.

Figs J-L. $\quad$ Hemiprionites typus (WAAGEN, 1895) with depression near venter. PIMUZ 37238, ×0.75. Anasibirites fauna, late Smithian.

Fig. M. Hemiprionites typus (WAAGEN, 1895) with depression near venter. PIMUZ 37239, $\times 0.75$. Anasibirites fauna, late Smithian.

Figs N-O. Hemiprionites typus (WAAGEN, 1895) with depression near venter. PIMUZ 37240, $\times 0.75$. Anasibirites fauna, late Smithian.

Figs P-R. Hemiprionites typus (WAAGEN, 1895) with depression near venter. PIMUZ 37241, $\times 0.75$. Anasibirites fauna, late Smithian.

Figs S-T. Hemiprionites typus (WAAGEN, 1895) with depression near venter. PIMUZ 37242, $\times 0.75$. Anasibirites fauna, late Smithian.

Figs U-W. Hemiprionites typus (WAAGEN, 1895) without depression near venter. PIMUZ 37243, ×0.75. Anasibirites fauna, late Smithian.

Figs X-Z. Hemiprionites typus (WAAGEN, 1895) without depression near venter. PIMUZ 37244, $\times 0.75$. Anasibirites fauna, late Smithian.

Fig. AA. Hemiprionites typus (WAAGEN, 1895) without depression near venter. PIMUZ 37245, $\times 0.75$. Anasibirites fauna, late Smithian.

Figs AB-AD. Hemiprionites typus (WAAGEN, 1895) without depression near venter. PIMUZ 37246, ×0.75. Anasibirites fauna, late Smithian.

Figs AE-AG. Hemiprionites typus (WAAGEN, 1895) without depression near venter. PIMUZ 37247, ×0.75. Anasibirites fauna, late Smithian.

Fig. AH. Hemiprionites typus (WAAGEN, 1895) without depression near venter. PIMUZ 37248, $\times 0.75$. Anasibirites fauna, late Smithian.

Figs AI-AK. Hemiprionites typus (WAAGEN, 1895) without depression near venter. PIMUZ 37249, ×0.75. Anasibirites fauna, late Smithian.

Fig. AL. Hemiprionites typus (WAAGEN, 1895) without depression near venter. Suture line of PIMUZ 37249 with scale bar representing $5 \mathrm{~mm}$, at $\mathrm{H}=11 \mathrm{~mm}$. Anasibirites fauna, late Smithian.

Figs AM-AN. Hemiprionites typus (WAAGEN, 1895) without depression near venter. PIMUZ 37250, ×0.75. Anasibirites fauna, late Smithian.

Figs AO-AQ. Hemiprionites walcotti (MATHEws, 1929). PIMUZ 37251, ×0.75. Anasibirites fauna, late Smithian.

Figs AR-AS. Hemiprionites walcotti (MATHEWS, 1929). PIMUZ 37252, $\times 0.75$. Anasibirites fauna, late Smithian.

Figs AT-U. Hemiprionites walcotti (MATHEWS, 1929). PIMUZ 37253, $\times 0.75$. Anasibirites fauna, late Smithian.

Figs AV-AX. Hemiprionites walcotti (MATHEWs, 1929). PIMUZ 37254, $\times 0.75$. Anasibirites fauna, late Smithian.

Figs AY-AZ. Hemiprionites walcotti (MATHEws, 1929). PIMUZ 37255, $\times 0.75$. Anasibirites fauna, late Smithian.

Fig. BA. Hemiprionites walcotti (MATHEWS, 1929). Suture line of PIMUZ 37252 with scale bar representing $5 \mathrm{~mm}$, at $\mathrm{H}=12.4 \mathrm{~mm}$. Anasibirites fauna, late Smithian.

Figs BB-BD. Hemiprionites walcotti (MATHEWS, 1929). PIMUZ 37257, ×0.75. Anasibirites fauna, late Smithian.

Figs BE-BG. Hemiprionites walcotti (MATHEWS, 1929). PIMUZ 37258, ×0.75. Anasibirites fauna, late Smithian. 
Figs A-C. Hedenstroemia evoluta (SPATH, 1934). PIMUZ 37256, ×0.5. Kashmirites fauna, early Smithian.

Fig. D. Hedenstroemia evoluta (SPATH, 1934). PIMUZ 37259, $\times 0.5$. Kashmirites fauna, early Smithian.

Figs E-G. Hedenstroemia evoluta (SPATH, 1934). PIMUZ 37260, $\times 0.5$. Kashmirites fauna, early Smithian.

Figs H-J. Hedenstroemia evoluta (SPATH, 1934). PIMUZ 37261, ×0.5. Kashmirites fauna, early Smithian.

Figs K-L. Hedenstroemia evoluta (SPATH, 1934). PIMUZ 37262, ×0.5. Kashmirites fauna, early Smithian.

Fig. M. Hedenstroemia evoluta (SPATH, 1934). Suture line of PIMUZ 37263 with scale bar representing $5 \mathrm{~mm}$, at H $=26.7 \mathrm{~mm}$. Kashmirites fauna, early Smithian.

Fig. N. Hedenstroemia evoluta (SPATH, 1934). Suture line of PIMUZ 37264 with scale bar representing $5 \mathrm{~mm}$, at $\mathrm{H}$ $=30.6 \mathrm{~mm}$. Kashmirites fauna, early Smithian.

Fig. O. Hedenstroemia evoluta (SPATH, 1934). Suture line of PIMUZ 37265 with scale bar representing $5 \mathrm{~mm}$, at H $=39 \mathrm{~mm}$. Kashmirites fauna, early Smithian.

Figs P-R. Mesohedenstroemia kwangsiana CHAO, 1959. PIMUZ 37266, ×2. Kashmirites fauna, early Smithian.

Figs S-U. Mesohedenstroemia kwangsiana CHAO, 1959. PIMUZ 37267, ×2. Kashmirites fauna, early Smithian.

Figs V-X. Mesohedenstroemia kwangsiana CHAO, 1959. PIMUZ 37268. Kashmirites fauna, early Smithian. 
Figs A-B. $\quad$ Pseudosageceras multilobatum NoETLING, 1905. PIMUZ 37269, $\times 0.5$. Owenites fauna, middle Smithian. Figs C-F. $\quad$ Pseudosageceras multilobatum NoETLING, 1905. PIMUZ 37270, ×0.5. Owenites fauna, middle Smithian.

Fig. G. Pseudosageceras multilobatum NoETLING, 1905. Suture line of PIMUZ 37270 with scale bar representing $5 \mathrm{~mm}$, at $\mathrm{H}=59.1 \mathrm{~mm}$. Owenites fauna, middle Smithian.

Figs H-I. Pseudosageceras multilobatum NoETLING, 1905. PIMUZ 37271. Owenites fauna, middle Smithian.

Fig. J. Pseudosageceras multilobatum NoETLING, 1905. Suture line of PIMUZ 37272 with scale bar representing $5 \mathrm{~mm}$, at $\mathrm{H}=16.6 \mathrm{~mm}$. Owenites fauna, middle Smithian.

Figs K-M. Pseudosageceras multilobatum NoETLING, 1905. PIMUZ 37272. Owenites fauna, middle Smithian.

Fig. N. Pseudosageceras multilobatum NoETLING, 1905. Suture line of PIMUZ 37273 with scale bar representing $5 \mathrm{~mm}$, at $\mathrm{H}=34.9 \mathrm{~mm}$. Owenites fauna, middle Smithian.

Figs O-R. $\quad$ Pseudosageceras multilobatum NoETLING, 1905. PIMUZ 37273. Owenites fauna, middle Smithian.

Figs S-T. Pseudosageceras multilobatum NOETLING, 1905. PIMUZ 37274, ×0.4. Kashmirites fauna, early Smithian.

Fig. U. Pseudosageceras multilobatum NoETLING, 1905. Suture line of PIMUZ 37275 with scale bar representing $5 \mathrm{~mm}$, at $\mathrm{H}=59.9 \mathrm{~mm}$. Owenites fauna, middle Smithian.

Figs V-W. $\quad$ Pseudosageceras multilobatum NoETLING, 1905. PIMUZ 37275, $\times 0.5$. Owenites fauna, middle Smithian.

Fig. X. $\quad$ Episageceras cf. intermedium WeLteR, 1922. Suture line of PIMUZ 37276 with scale bar representing 5 $\mathrm{mm}$, at $\mathrm{H}=12.5 \mathrm{~mm}$. Kashmirites fauna, early Smithian.

Figs Y-AA. Episageceras cf. intermedium WELTER, 1922. PIMUZ 37276. Kashmirites fauna, early Smithian.

Figs AB-AC. Episageceras sp. indet. PIMUZ 37277. Owenites fauna, middle Smithian.

Figs AD-AE. Episageceras sp. indet. PIMUZ 37278. Owenites fauna, middle Smithian.

Fig. AF. Episageceras sp. indet. Suture line of PIMUZ 37278 with scale bar representing $5 \mathrm{~mm}$, at $\mathrm{H}=7 \mathrm{~mm}$. Owenites fauna, middle Smithian. 
Figs A-C. $\quad$ Pseudaspenites layeriformis (WELTER, 1922). PIMUZ 37279, $\times 0.75$. Owenites fauna, middle Smithian. Figs D-F. Pseudaspenites layeriformis (WELTER, 1922). PIMUZ 37280, $\times 0.75$. Owenites fauna, middle Smithian. Figs G-H. $\quad$ Pseudaspenites layeriformis (WELTER, 1922). PIMUZ 37281, $\times 0.75$. Owenites fauna, middle Smithian. Figs I-K. $\quad$ Pseudaspenites layeriformis (WELTER, 1922). PIMUZ 37282, $\times 0.75$. Owenites fauna, middle Smithian. Figs L-M. $\quad$ Pseudaspenites layeriformis (WELTER, 1922). PIMUZ 37283, $\times 0.75$. Owenites fauna, middle Smithian. Figs N-O. $\quad$ Pseudaspenites layeriformis (WELTER, 1922). PIMUZ 37284, $\times 0.75$. Owenites fauna, middle Smithian. Figs P-R. $\quad$ Pseudaspenites layeriformis (WELTER, 1922). PIMUZ 37285, $\times 0.75$. Owenites fauna, middle Smithian. Figs S-U. $\quad$ Pseudaspenites layeriformis (WELTER, 1922). PIMUZ 37286, $\times 0.75$. Owenites fauna, middle Smithian. Figs V-X. $\quad$ Pseudaspenites layeriformis (WELTER, 1922). PIMUZ 37287, $\times 0.75$. Owenites fauna, middle Smithian. Fig. Y. $\quad$ Pseudaspenites layeriformis (WELTER, 1922). PIMUZ 37288, $\times 0.75$. Owenites fauna, middle Smithian. Figs Z-AA. Pseudaspenites layeriformis (WELTER, 1922). PIMUZ 37289, $\times 0.75$. Owenites fauna, middle Smithian. Fig. AB. $\quad$ Pseudaspenites layeriformis (WELTER, 1922). PIMUZ 37290, $\times 0.75$. Owenites fauna, middle Smithian. Fig. AC. $\quad$ Pseudaspenites layeriformis (WELTER, 1922). PIMUZ 37291, $\times 0.75$. Owenites fauna, middle Smithian.

Fig. AD. $\quad$ Pseudaspenites layeriformis (WELTER, 1922). Suture line of PIMUZ 37279 with scale bar representing $5 \mathrm{~mm}$, at $\mathrm{H}=13.3 \mathrm{~mm}$. Owenites fauna, middle Smithian.

Figs AE-AH. Aspenites acutus HyATt \& SMITH, 1905. PIMUZ 37292, ×0.75. Owenites fauna, middle Smithian. 
Figs A-C. Ussuria schamarae DiENER, 1895. PIMUZ 37293, ×0.75. Owenites fauna, middle Smithian.

Figs D-F. ? Parussuria sp. indet. PIMUZ 37294. Owenites fauna, middle Smithian.

Fig. G. ? Parussuria sp. indet. Suture line of PIMUZ 37294 with scale bar representing $5 \mathrm{~mm}$, at $\mathrm{H}=11.5 \mathrm{~mm}$. Owenites fauna, middle Smithian.

Figs H-J. Genus gen. indet. B. PIMUZ 37295. Smithian?

Fig. K. Goudemandites cf. sinensis BRÜHWILER \& BUCHER, 2012a. PIMUZ 37296. Owenites fauna, middle Smithian.

Figs L-N. Genus gen. indet. C. PIMUZ 37297. Kashmirites fauna, early Smithian. 
Text-fig. 1. Chronostratigraphic subdivisions of the Early Triassic calibrated with published radiometric ages (OVTCHAROVA et al. 2006; GALFETTI et al. 2007; OvTCHAROVA et al. 2015; BARESEL et al. 2017). $\delta \mathrm{C}^{13}$ carb curves and anoxic/euxinic events from GALFETTI et al. 2007. A: Anasibirites, X: Xenoceltites, ea.: early, mi.: middle, l.: late. Simplified ammonoid diversity curve is inferred from data from BRAYARD et al. (2006; 2009a), BRÜHWILER et al. (2010a), WARE et al. (2015) and JATTIOT et al. (2016).

Text-fig. 2. Map of Timor showing the location of Lidak, Noe Tobe and Bihati localities in West Timor (black stars). Modified after CHARLTON et al. (2009).

Text-fig. 3. Timor ammonoid zonation and correlation with other Smithian successions. Spa. Spathian, Dien. Dienerian. Modified after BRAYARD et al. (2013).

Text-fig. 4. Scatter diagrams of H, W and U, and H/D, W/D, and U/D for Kashmirites armatus (open symbols indicate specimens from Timor, Kashmirites fauna $[\mathrm{n}=8]$; grey symbols indicate specimens from Pakistan, data from BRÜHWILER et al. 2012b [n=3]).

Text-fig. 5. Scatter diagrams of H, W and U, and H/D, W/D, and U/D for Kashmirites baidi (open symbols indicate specimens from Timor, Kashmirites fauna [ $=1]$; grey symbols indicate specimens from Oman and Pakistan, data from BRÜHWILER et al. 2012a; BRÜHWILER et al. b [n = 6]).

Text-fig. 6. Scatter diagrams of H, W and U, and H/D, W/D, and U/D for Kashmirites cf. guangxiense (open symbols indicate specimens from Timor, Kashmirites fauna $[\mathrm{n}=2]$; grey symbols indicate specimens from China, data from BRAYARD \& BUCHER, 2008 [n = 9]).

Text-fig. 7. Scatter diagrams of H, W and U, and H/D, W/D, and U/D for Kashmirites nivalis (open symbols indicate specimens from Timor, Kashmirites fauna [ $\mathrm{n}=15]$; grey symbols indicate specimens from Spiti, data from BRÜHWILER et al. 2012c [n=2]).

Text-fig. 8. Scatter diagrams of $\mathrm{H}, \mathrm{W}$ and U, and H/D, W/D, and U/D for Pseudoceltites multiplicatus (open symbols indicate specimens from Timor, Owenites fauna [n = 17]; grey symbols indicate specimens from Spiti, Pakistan and Tibet, data from BRÜHWILER et al. 2010b; BRÜHWILER et al. 2012b; BRÜHWILER et al. 2012c [n= 44]).

Text-fig. 9. Scatter diagrams of H, W and U, and H/D, W/D, and U/D for Pseudoceltites densistriatus from Timor, Owenites fauna $(\mathrm{n}=7)$.

Text-fig. 10. Scatter diagrams of H, W and U, and H/D, W/D, and U/D for Nyalamites angustecostatus (open symbols indicate specimens from Timor, Owenites fauna $[\mathrm{n}=25]$; grey symbols indicate specimens from Spiti, Oman, Pakistan and Tibet, data from BRÜHWILER et al. 2010b; BRÜHWILER et al. 2012a; BRÜHWILER et al. 2012b; BRÜHWILER et al. 2012c [n = 22]).

Text-fig. 11. Scatter diagrams of H, W and U, and H/D, W/D, and U/D for Hanielites elegans (open symbols indicate specimens from Timor, Owenites fauna $[n=2]$; grey symbols indicate specimens from Spiti and China, data from BRAYARD \& BUCHER 2008 ; BRÜHWILER et al. 2012c [n = 10]).

Text-fig. 12. Scatter diagrams of H, W and U, and H/D, W/D, and U/D for Hanielites gracilus (open symbols indicate specimens from Timor, Owenites fauna $[\mathrm{n}=6]$; grey symbols indicate specimens from China, data from BRAYARD \& BUCHER $2008[n=1])$.

Text-fig. 13. Scatter diagrams of H, W and U, and H/D, W/D, and U/D for Roopnarinites n. gen. paucesculptatum. All specimens from Timor (open symbols indicate specimens from this work, Owenites fauna $[n=8]$, grey symbols indicate holotype, from WELTER 1922).

Text-fig. 14. Scatter diagrams of H, W and U, and H/D, W/D, and U/D for Paraspidites bicarinatus n. sp. Kashmirites fauna $[\mathrm{n}=5]$.

Text-fig. 15. Scatter diagrams of $\mathrm{H}, \mathrm{W}$ and $\mathrm{U}$, and H/D, W/D, and U/D for Galfettites simplicitatis (open symbols indicate specimens from Timor, Owenites fauna [ $\mathrm{n}=3$ ]; grey symbols indicate specimens from China and Oman, data from BRAYARD \& BUCHER 2008 and BRÜHWILER et al. 2012a [n = 15]).

Text-fig. 16. Scatter diagrams of $\mathrm{H}, \mathrm{W}$ and $\mathrm{U}$, and H/D, W/D, and U/D for Paranorites cf. ambiensis (open symbols indicate specimens from Timor, Kashmirites fauna $[n=2]$, grey symbols indicate specimens from Pakistan; data from BRÜHWILER et al. 2012b [ $\mathrm{n}=9])$. 
Text-fig. 17. Scatter diagrams of H, W and U, and H/D, W/D, and U/D for Vercherites cf. vercherei (open symbols indicate specimens from Timor, Kashmirites fauna $[\mathrm{n}=2]$, grey symbols indicate specimens from Pakistan; data from BRÜHWILER et al. 2012b [n = 10]).

Text-fig. 18. Scatter diagrams of $H, W$ and $U$, and H/D, W/D, and U/D for Urdyceras tulongensis from Timor (open symbols, Owenites fauna [n=4]) and from Spiti (grey symbols, data from BRÜHWILER et al. 2012c [n= 8]); and for the holotype of Urdyceras insolitus (dark symbols, data from BRÜHWILER et al. 2010b).

Text-fig. 19. Scatter diagrams of $H, W$ and U, and H/D, W/D, and U/D for Safraites simplex (open symbols indicate specimens from Timor, Owenites fauna [n $=1]$; grey symbols indicate specimens from Oman, data from BRÜHWILER et al. 2012a [n=16]).

Text-fig. 20. Scatter diagrams of H, W and U, and H/D, W/D, and U/D for Flemingites flemingianus (open symbols indicate specimens from Timor, Kashmirites fauna $[\mathrm{n}=1]$; grey symbols indicate specimens from Pakistan; data from BRÜHWILER et al. 2012b [n = 5]).

Text-fig. 21. Scatter diagrams of H, W and U, and H/D, W/D, and U/D for Flemingites cf. planatus (open symbols indicate specimens from Timor, Kashmirites fauna $[\mathrm{n}=1]$ ) and for Flemingites planatus from Pakistan (grey symbols, with holotype in dark symbols, data from BRÜHWILER et al. 2012b [n = 3]).

Text-fig. 22. Scatter diagrams of $\mathrm{H}, \mathrm{W}$ and $\mathrm{U}$, and H/D, W/D, and U/D for Flemingites pulcher. All specimens from Timor (open symbols indicate specimens from this work, Kashmirites fauna [n $=4]$; grey symbols indicate holotype, from WELTER 1922).

Text-fig. 23. Scatter diagrams of H, W and U, and H/D, W/D, and U/D for Rohillites rohilla (open symbols indicate specimens from Timor, Kashmirites fauna [ $\mathrm{n}=8$ ]; dark symbols indicate holotype from Spiti, data from DIENER 1897) and for Rohillites omanensis (grey symbols, data from BRÜHWILER et al. 2012a [n = 6]).

Text-fig. 24. Scatter diagrams of $\mathrm{H}, \mathrm{W}$ and $\mathrm{U}$, and H/D, W/D, and U/D for Pseudoflemingites timorensis from Timor (open symbols, Kashmirites fauna $[\mathrm{n}=6]$ ) and for Pseudoflemingites cf. timorensis from Pakistan (grey symbols, data from BRÜHWILER et al. 2012b [n = 3]).

Text-fig. 25. Scatter diagrams of H, W and U, and H/D, W/D, and U/D for Subflemingites involutus. All specimens from Timor (open symbols indicate specimens from this work, Kashmirites fauna $[\mathrm{n}=4]$; grey symbols indicate holotype, from WELTER 1922).

Text-fig. 26. Scatter diagrams of H, W and U, and H/D, W/D, and U/D for Anaxenaspis orientale. All specimens from Timor (open symbols, Owenites fauna $[\mathrm{n}=21]$ ).

Text-fig. 27. Scatter diagrams of $\mathrm{H}, \mathrm{W}$ and $\mathrm{U}$, and H/D, W/D, and U/D for Anaxenaspis compressus (open symbols indicate specimens from Timor, Owenites fauna $[n=5]$; grey symbols indicate specimens from Tibet, data from BRÜHWILER et al. 2010b [n=6]).

Text-fig. 28. Scatter diagrams of H, W and U, and H/D, W/D, and U/D for Baidites tenue from Timor (open symbols, Kashmirites fauna $[\mathrm{n}=4]$ ) and for Baidites hermanni from Oman (grey symbols, with holotype in dark symbols, data from BRÜHWILER et al. 2012a [n = 7]).

Text-fig. 29. Scatter diagrams of H, W and U, and H/D, W/D, and U/D for Baidites crassecostatum. All specimens from Timor (open symbols indicate specimens from this work, Kashmirites fauna $[\mathrm{n}=6]$; grey symbols indicate paratype and dark symbols indicate holotype, from WELTER 1922).

Text-fig. 30. Scatter diagrams of H, W and U, and H/D, W/D, and U/D for Baidites obesus n. sp. from Timor (open symbols, Kashmirites fauna [ $\mathrm{n}=2]$ ) and for Baidites crassecostatum from Timor (grey symbols, this work, Kashmirites fauna [ $\mathrm{n}=6]$; dark symbols indicate holotype, from WELTER 1922).

Text-fig. 31. Scatter diagrams of H, W and U, and H/D, W/D, and U/D for Dieneroceras dieneri from Timor (open symbols, Owenites fauna $[\mathrm{n}=5]$ ) and for Dieneroceras cf. dieneri from Oman (grey symbols, data from BRÜHWILER et al. 2012a [n= 25]). 
Text-fig. 32. Scatter diagrams of H, W and U, and H/D, W/D, and U/D for Dieneroceras cf. tientungense (open symbols indicate specimens from Timor, Kashmirites fauna $[n=7]$; grey symbols indicate specimens from China, data from BRAYARD \& BUCHER 2008 [ $=58]$ ).

Text-fig. 33. Scatter diagrams of $\mathrm{H}, \mathrm{W}$ and $\mathrm{U}$, and H/D, W/D, and U/D for Owenites koeneni (open symbols indicate specimens from Timor, Owenites fauna $[n=11]$; grey symbols indicate specimens from Oman, data from BRÜHWILER et al. 2012a [n=15]).

Text-fig. 34. Scatter diagrams of H, W and U, and H/D, W/D, and U/D for Owenites egrediens. All specimens from Timor (open symbols, Owenites fauna [n=11]).

Text-fig. 35. Scatter diagrams of $\mathrm{H}, \mathrm{W}$ and $\mathrm{U}$, and H/D, W/D, and U/D for Owenites simplex (open symbols indicate specimens from Timor, Owenites fauna [n=13]; grey symbols indicate specimens from Oman, data from BRÜHWILER et al. 2012a [n=5]).

Text-fig. 36. Scatter diagrams of $\mathrm{H}, \mathrm{W}$ and $\mathrm{U}$, and H/D, W/D, and U/D for Owenites sp. indet. All specimens from Timor (open symbols, Owenites fauna [n = 23]).

Text-fig. 37. Scatter diagrams of H, W and U, and H/D, W/D, and U/D for Steckites brevus (open symbols indicate specimens from Timor, Owenites fauna [n = 21]; grey symbols indicate specimens from Spiti, data from BRÜHWILER et al. 2012c [n=2]).

Text-fig. 38. Scatter diagrams of H, W and U, and H/D, W/D, and U/D for Juvenites spathi (open symbols indicate specimens from Timor, Owenites fauna $[\mathrm{n}=14]$; grey symbols indicate specimens from China and Oman, data from BRAYARD \& BUCHER 2008; BRÜHWILER et al. 2012a [n = 82]).

Text-fig. 39. Scatter diagrams of H, W and U, and H/D, W/D, and U/D for Juvenites septentrionalis from Timor (open symbols, Owenites fauna $[\mathrm{n}=4]$ ) and for Juvenites thermarum from Oman, Utah and Nevada (grey symbols, data from BRÜHWILER et al. 2012a; BRAYARD et al. 2013; JATTIOT et al. 2017 [ $n=39]$ ).

Text-fig. 40. Scatter diagrams of H, W and U, and H/D, W/D, and U/D for Subvishnuites welteri (open symbols indicate specimens from Timor, Owenites fauna $[\mathrm{n}=10]$; grey symbols indicate specimens from China and Oman, data from BRAYARD \& BUCHER 2008; BRÜHWILER et al. 2012a [n = 12]).

Text-fig. 41. Scatter diagrams of H, W and U, and H/D, W/D, and U/D for Subvishnuites cf. posterus from Timor (open symbols, Anasibirites fauna [n $=1]$ ) and for Subvishnuites posterus from Spiti (grey symbols, data from BRÜHWILER et al. 2012c [n=8]).

Text-fig. 42. Scatter diagrams of H, W and U, and H/D, W/D, and U/D for Hochuliites retrocostatus (open symbols indicate specimens from Timor, Owenites fauna $[n=3]$; grey symbols indicate specimens from Pakistan, with holotype in dark symbols, data from BRÜHWILER et al. 2012b [n = 2]).

Text-fig. 43. Scatter diagrams of H, W and U, and H/D, W/D, and U/D for Truempyceras pluriformis (open symbols indicate specimens from Timor, Owenites fauna $[\mathrm{n}=17]$; grey symbols indicate specimens from Pakistan, data from BRÜHWILER et al. 2012b [ $n=5])$.

Text-fig. 44. Scatter diagrams of H, W and U, and H/D, W/D, and U/D for Truempyceras compressum (open symbols indicate specimens from Timor, Owenites fauna [n $=14]$; grey symbols indicate specimens from Spiti, data from BRÜHWILER et al. 2012c [ $n=8]$ ).

Text-fig. 45. Scatter diagrams of $\mathrm{H}, \mathrm{W}$ and $\mathrm{U}$, and H/D, W/D, and U/D for Brayardites compressus (open symbols indicate specimens from Timor, Owenites fauna $[\mathrm{n}=10]$; grey symbols indicate specimens from Tibet, data from BRÜHWILER et al. 2010b [ $\mathrm{n}=17])$.

Text-fig. 46. Scatter diagrams of H, W and U, and H/D, W/D, and U/D for Brayardites malayicum from Timor (open symbols, Owenites fauna [ $\mathrm{n}=13$ ]; black symbols indicate holotype, from WeLTER 1922) and for Brayardites cf. malayicum from Timor (grey symbols, Owenites fauna $[\mathrm{n}=5]$ ).

Text-fig. 47. Scatter diagrams of H, W and U, and H/D, W/D, and U/D for ?Nammalites cf. pilatoides from Timor (open symbols, Owenites fauna [ $\mathrm{n}=3]$ ) and for Nammalites pilatoides from Spiti (grey symbols, data from BRÜHWILER et al. 2012c [ $\mathrm{n}=23]$ ). 
Text-fig. 48. Scatter diagrams of $\mathrm{H}, \mathrm{W}$ and $\mathrm{U}$, and H/D, W/D, and U/D for Prionites tuberculatus (open symbols indicate specimens from Timor, Owenites fauna $[\mathrm{n}=7]$; grey symbols indicate specimens from Pakistan, data from BRÜHWILER et al. 2012b [n=12]).

Text-fig. 49. Scatter diagrams of H, W and U, and H/D, W/D, and U/D for Prionites involutus (open symbols indicate specimens from Timor, Owenites fauna $[\mathrm{n}=2]$; grey symbols indicate specimens from Tibet, data from BRÜHWILER et al. 2010b [n=4]).

Text-fig. 50. Scatter diagrams of H, W and U, and H/D, W/D, and U/D for Prionites nammalensis (open symbols indicate specimens from Timor, Owenites fauna $[\mathrm{n}=1]$; grey symbols indicate specimens from Pakistan, data from BRÜHWILER et al. 2012b [n=6]).

Text-fig. 51. Scatter diagrams of H, W and U, and H/D, W/D, and U/D for Stephanites superbus (open symbols indicate specimens from Timor, Owenites fauna [n $=1]$; grey symbols indicate specimens from Pakistan, data from BRÜHWILER et al. 2012b [n=2]).

Text-fig. 52. Scatter diagrams of H, W and U, and H/D, W/D, and U/D for Arctoprionites resseri (open symbols indicate specimens from Timor, Owenites fauna [n $=4]$; grey symbols indicate specimens from Nevada, data from JATTIOT et al. $2017[n=7])$.

Text-fig. 53. Scatter diagrams of H, W and U, and H/D, W/D, and U/D for Hemiprionites typus. All specimens from Timor (open symbols indicate specimens without depression, Anasibirites fauna $[\mathrm{n}=65]$; grey symbols indicate specimens with depression, Anasibirites fauna [n=121]).

Text-fig. 54. Scatter diagrams of $\mathrm{H}, \mathrm{W}$ and $\mathrm{U}$, and H/D, W/D, and U/D for Hemiprionites walcotti (open symbols indicate specimens from Timor, Anasibirites fauna $[\mathrm{n}=11]$; grey symbols indicate specimens from Nevada, data from JATTIOT et al. 2017 [n = 26]).

Text-fig. 55. Scatter diagrams of H, W and U, and H/D, W/D, and U/D for Hedenstroemia evoluta (open symbols indicate specimens from Timor, Kashmirites fauna [ $=13$ ]; grey symbols indicate specimens from Pakistan, data from BRÜHWILER et al. 2012b [n = 3]).

Text-fig. 56. Scatter diagrams of $\mathrm{H}, \mathrm{W}$ and $\mathrm{U}$, and H/D, W/D, and U/D for Pseudosageceras multilobatum. All specimens from Timor, Kashmirites and Owenites faunas (open symbols indicate specimens with an acute venter, [n = 2]; grey symbols indicate specimens with a bicarinate venter, [ $n=6])$.

Text-fig. 57. Scatter diagrams of $\mathrm{H}, \mathrm{W}$ and $\mathrm{U}$, and H/D, W/D, and U/D for Aspenites acutus (open symbols indicate specimens from Timor, Owenites fauna $[\mathrm{n}=1]$; grey symbols indicate specimens from Oman and Spiti, data from BRÜHWILER et al. 2012a; BRÜHWILER et al. 2012c [n = 7]).

Text-fig. 58. Scatter diagrams of H, W and U, and H/D, W/D, and U/D for Pseudaspenites layeriformis (open symbols indicate specimens from Timor, this work, Owenites fauna $[n=21]$, dark symbols indicate the holotype from Timor, data from WELTER 1922; grey symbols indicate specimens from China and Spiti, data from BRAYARD \& BUCHER 2008; BRÜHWILER et al. 2012c [ $\mathrm{n}=15])$.

Text-fig. 59. Scatter diagrams of $\mathrm{H}, \mathrm{W}$ and $\mathrm{U}$, and H/D, W/D, and U/D for Ussuria schamarae (open symbols indicate specimens from Timor, Owenites fauna [n=1], dark symbols indicate the holotype from Russia, data from DIENER 1895) and for the holotype of Ussuria iwanowi from Russia (grey symbols, data from DIENER 1895). 

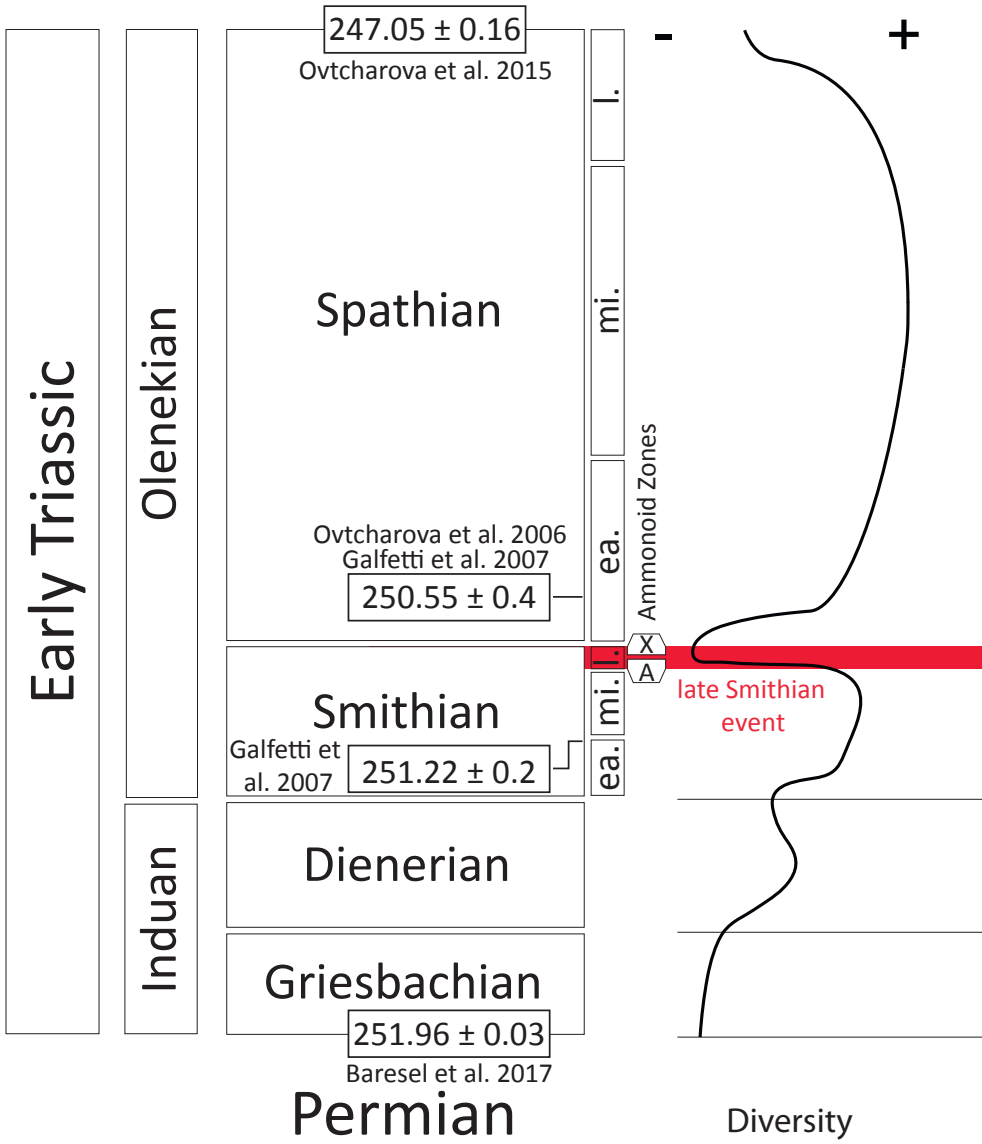


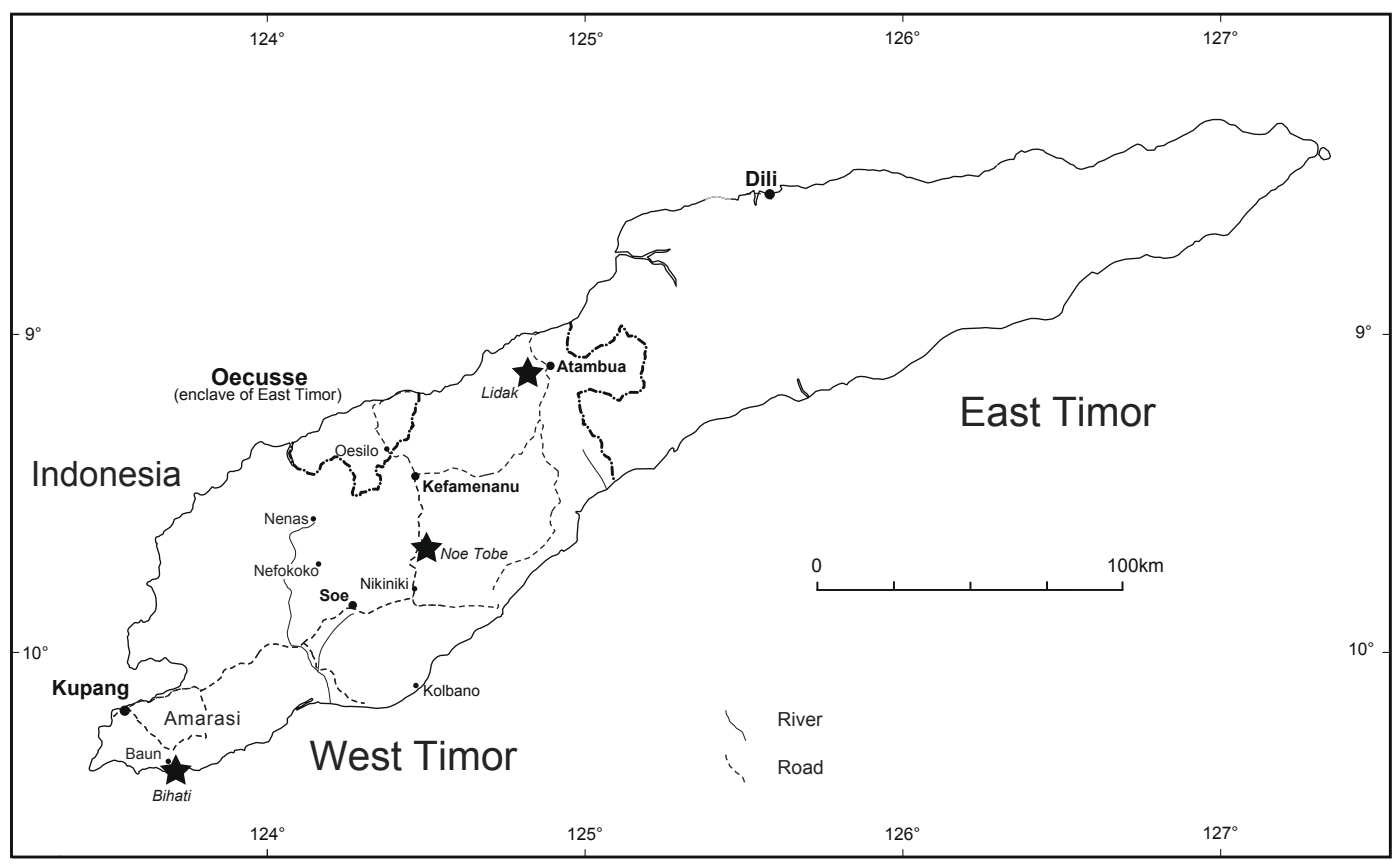




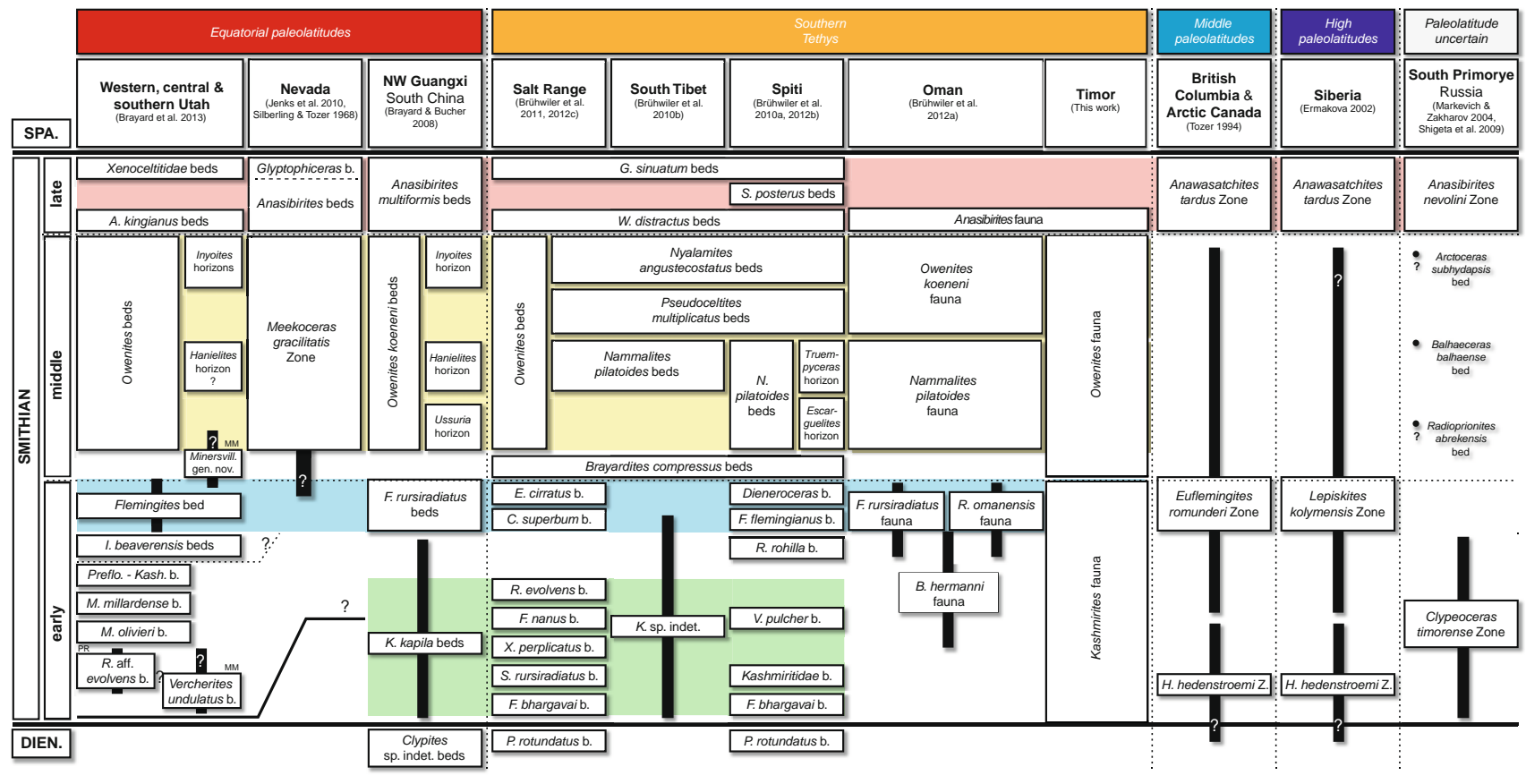




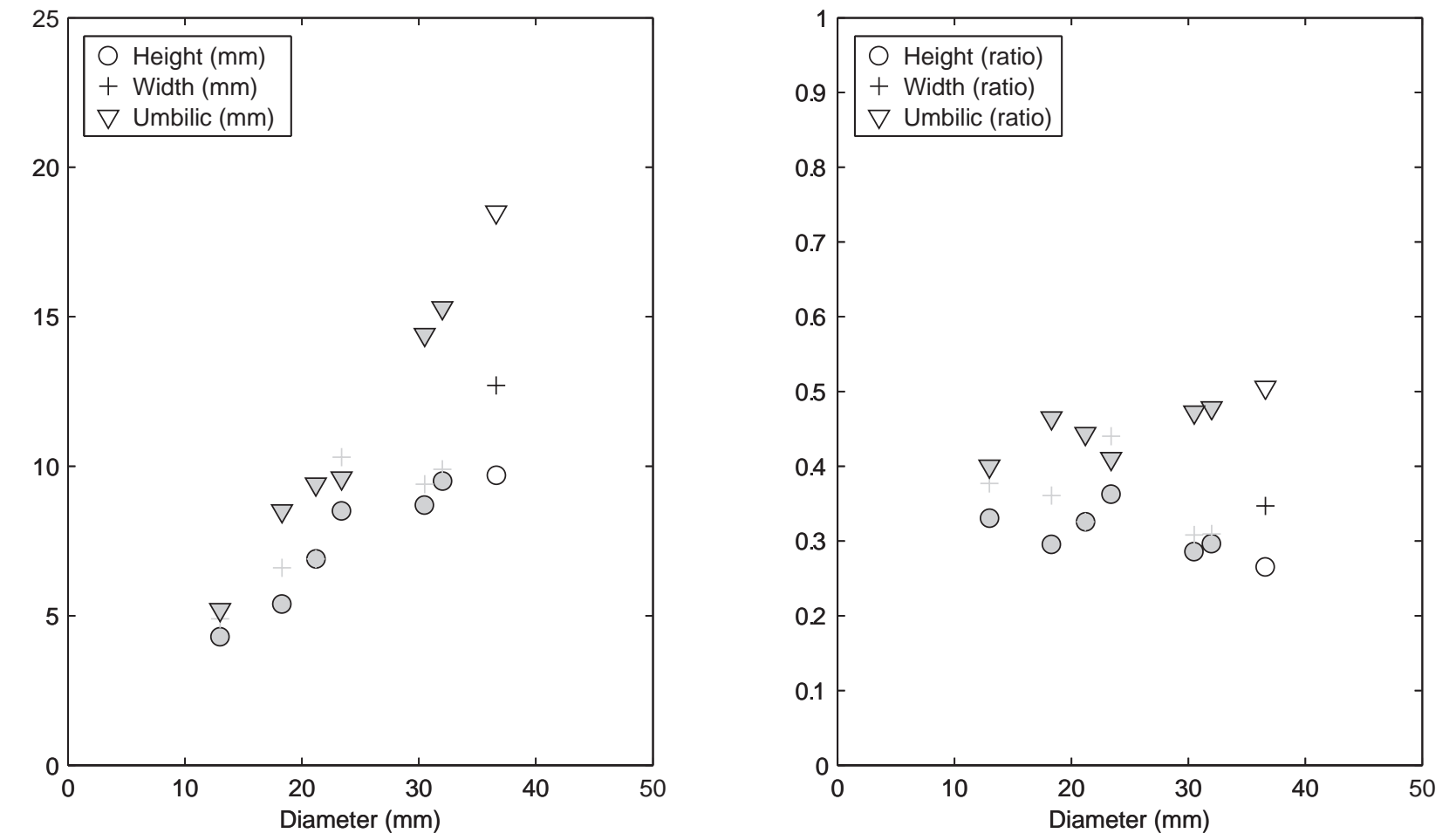



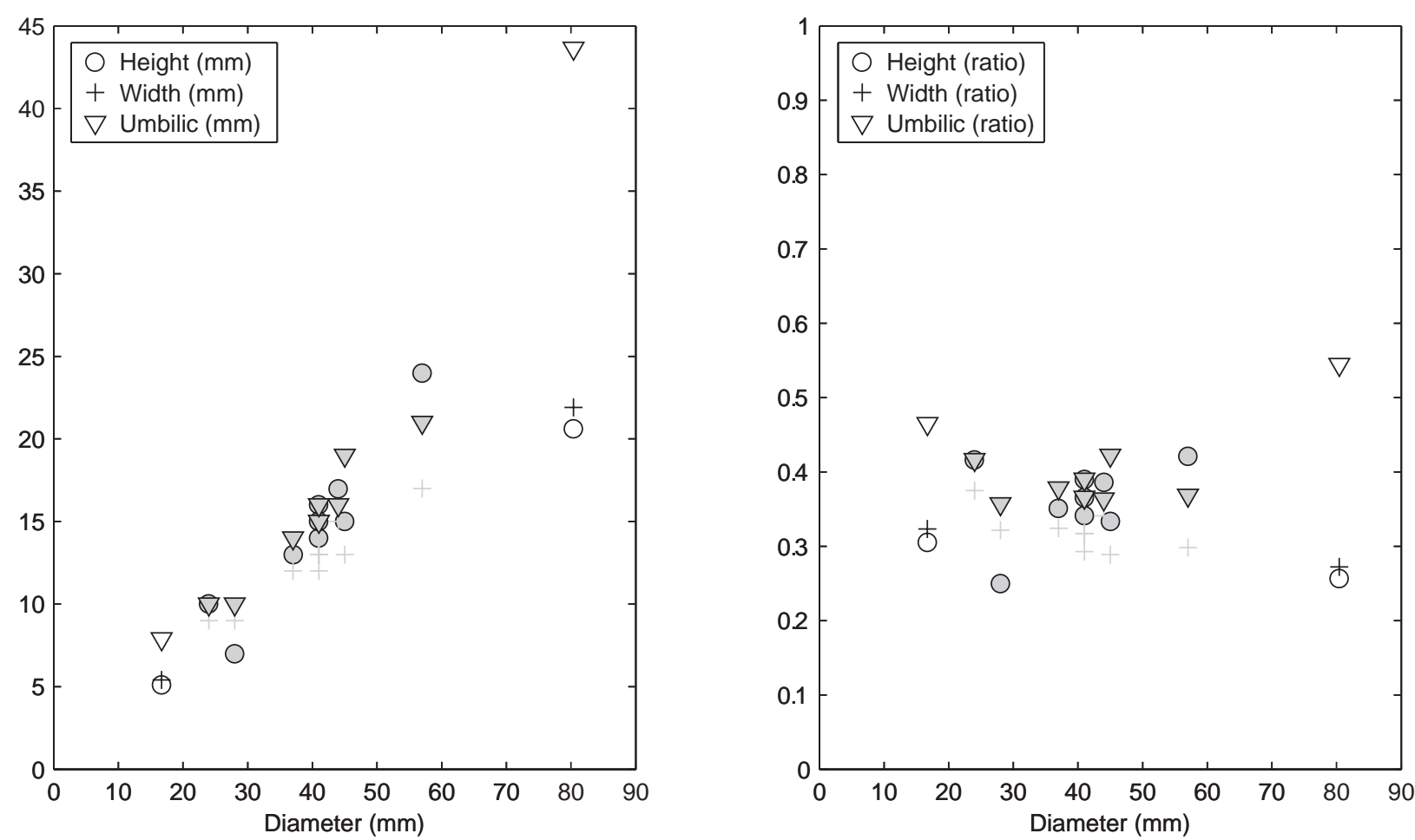


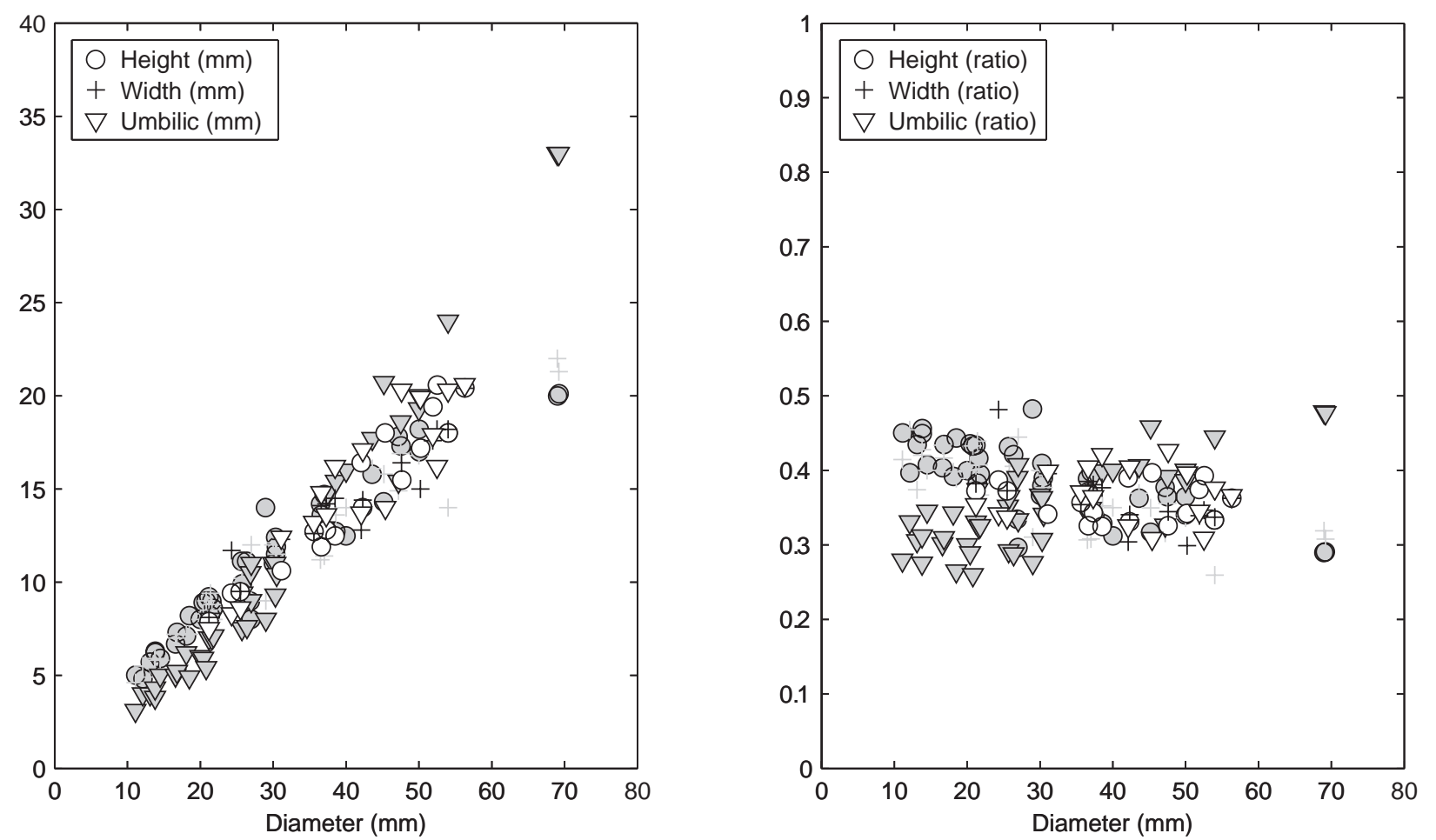



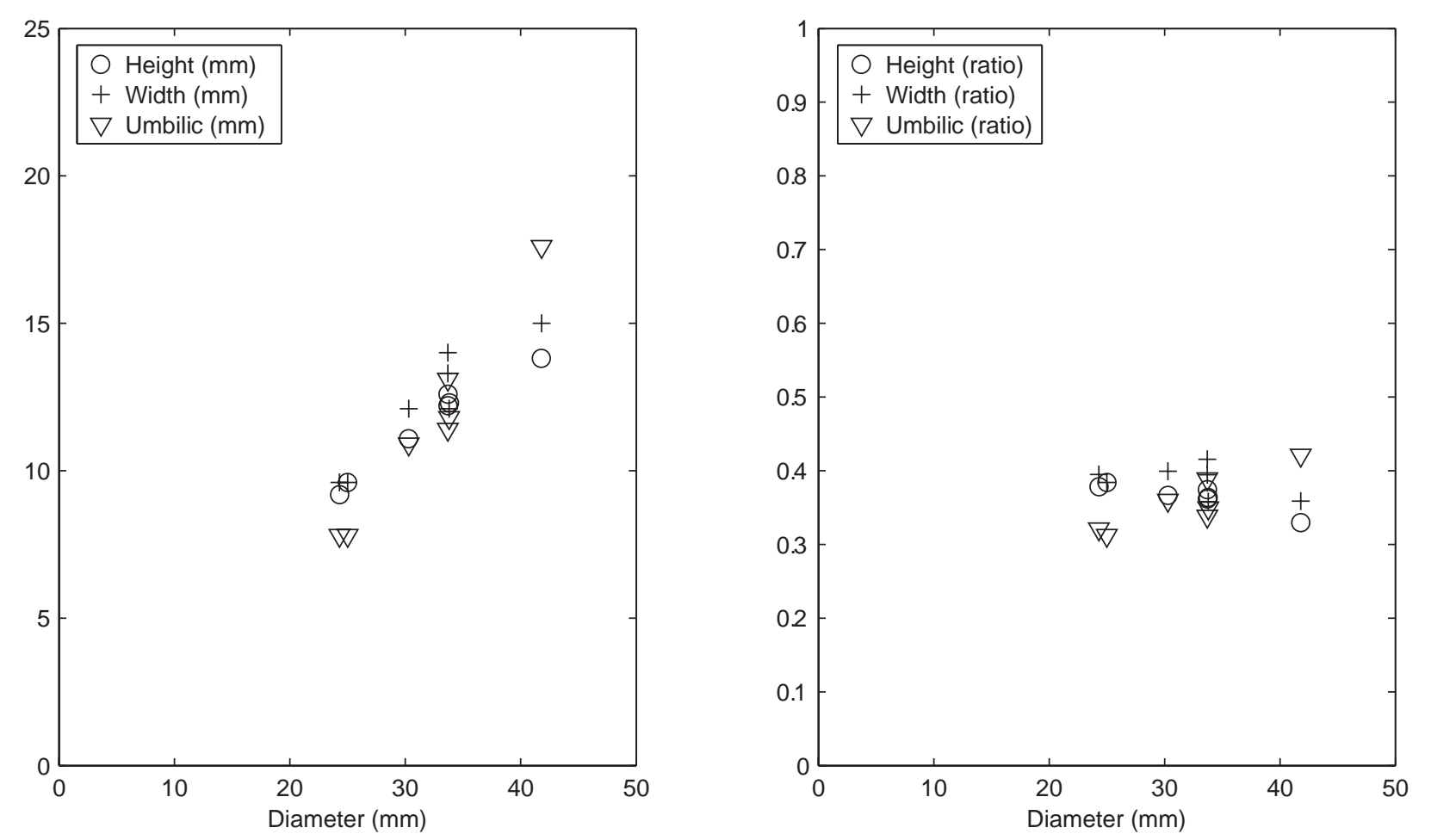


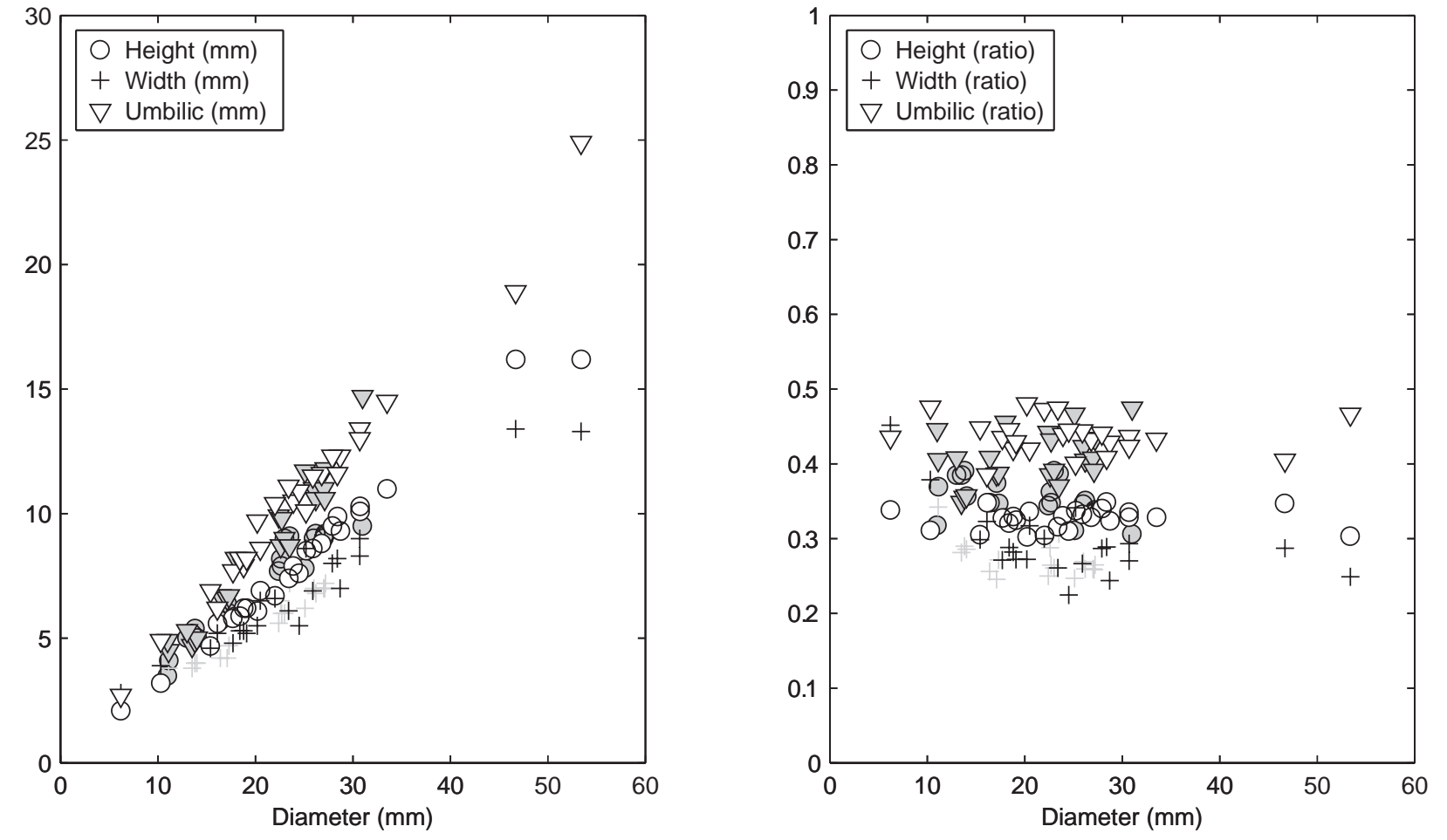




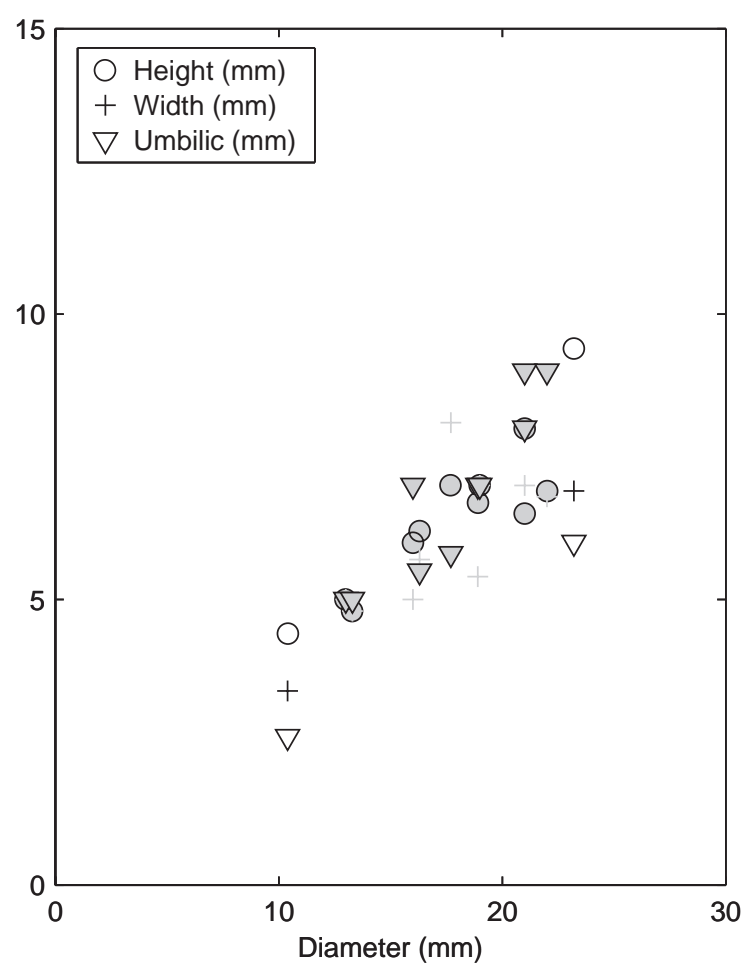



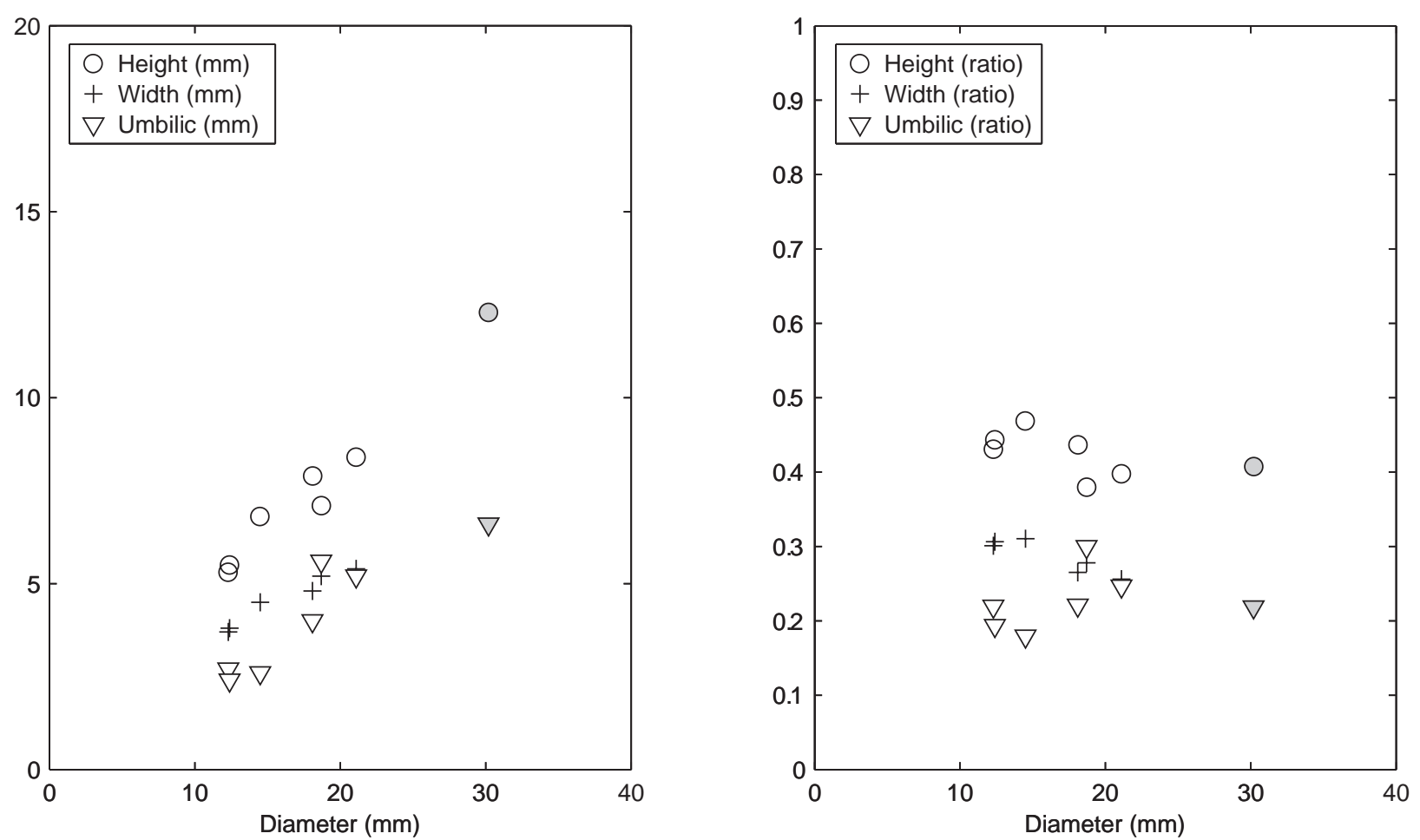

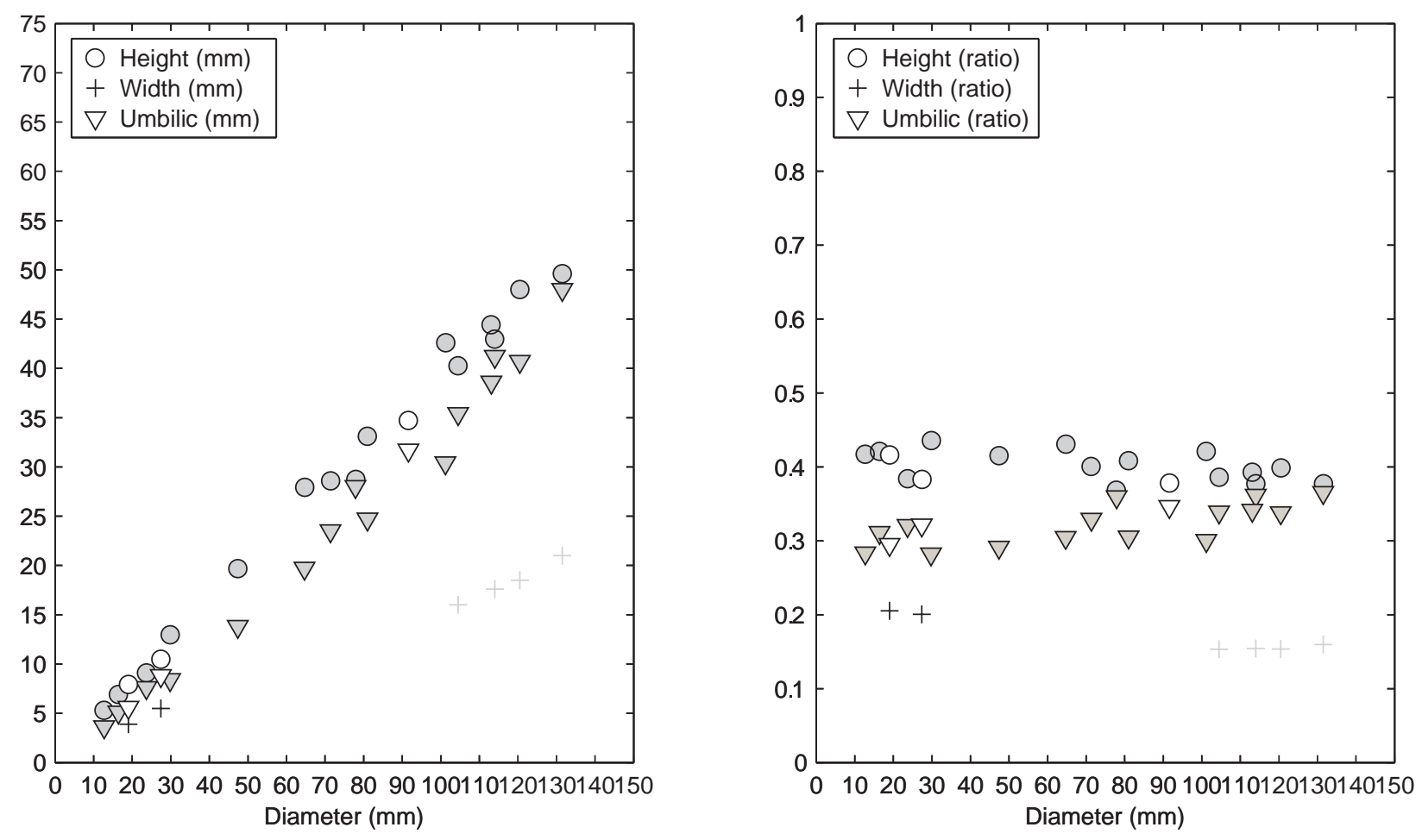


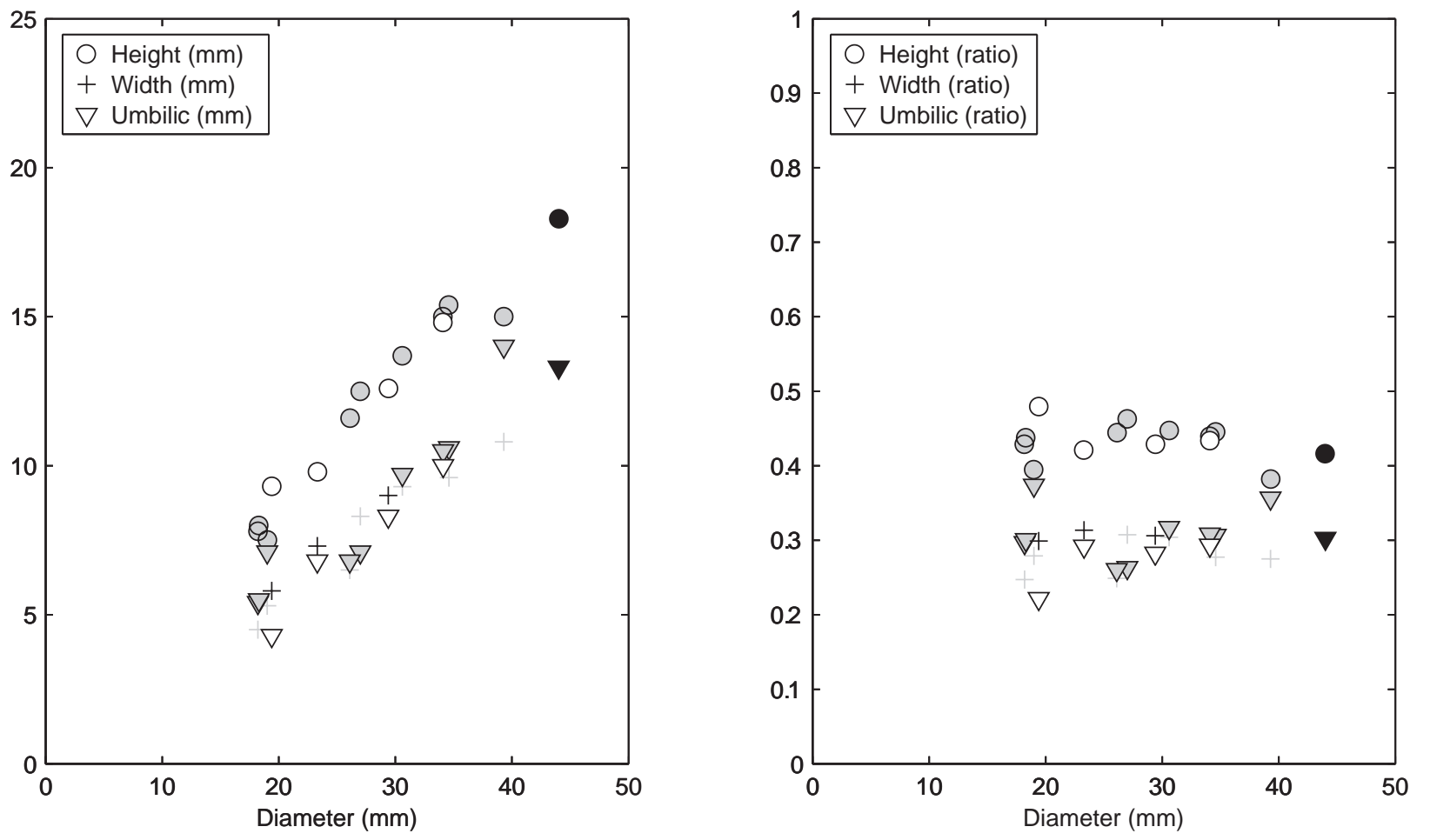




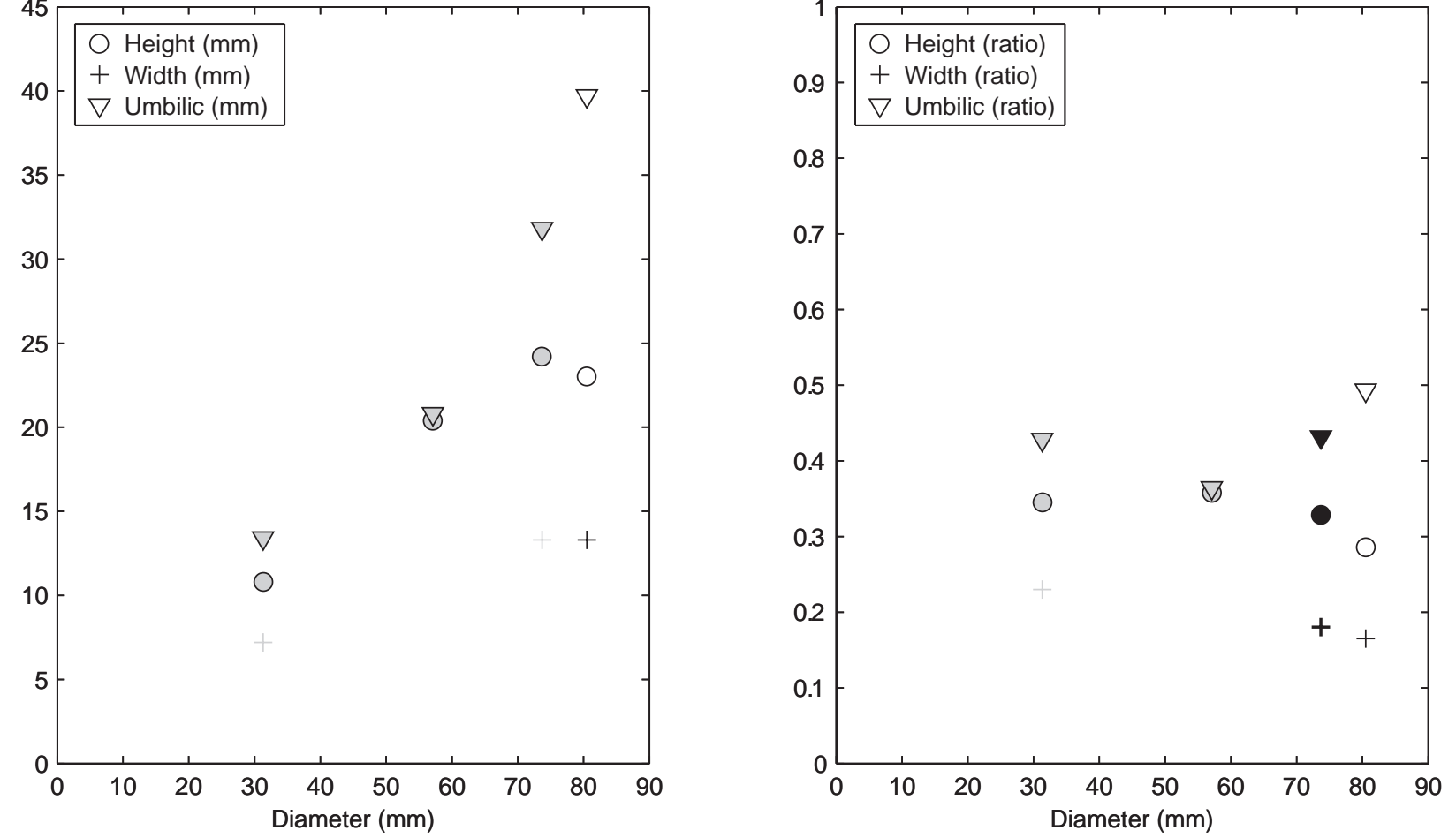




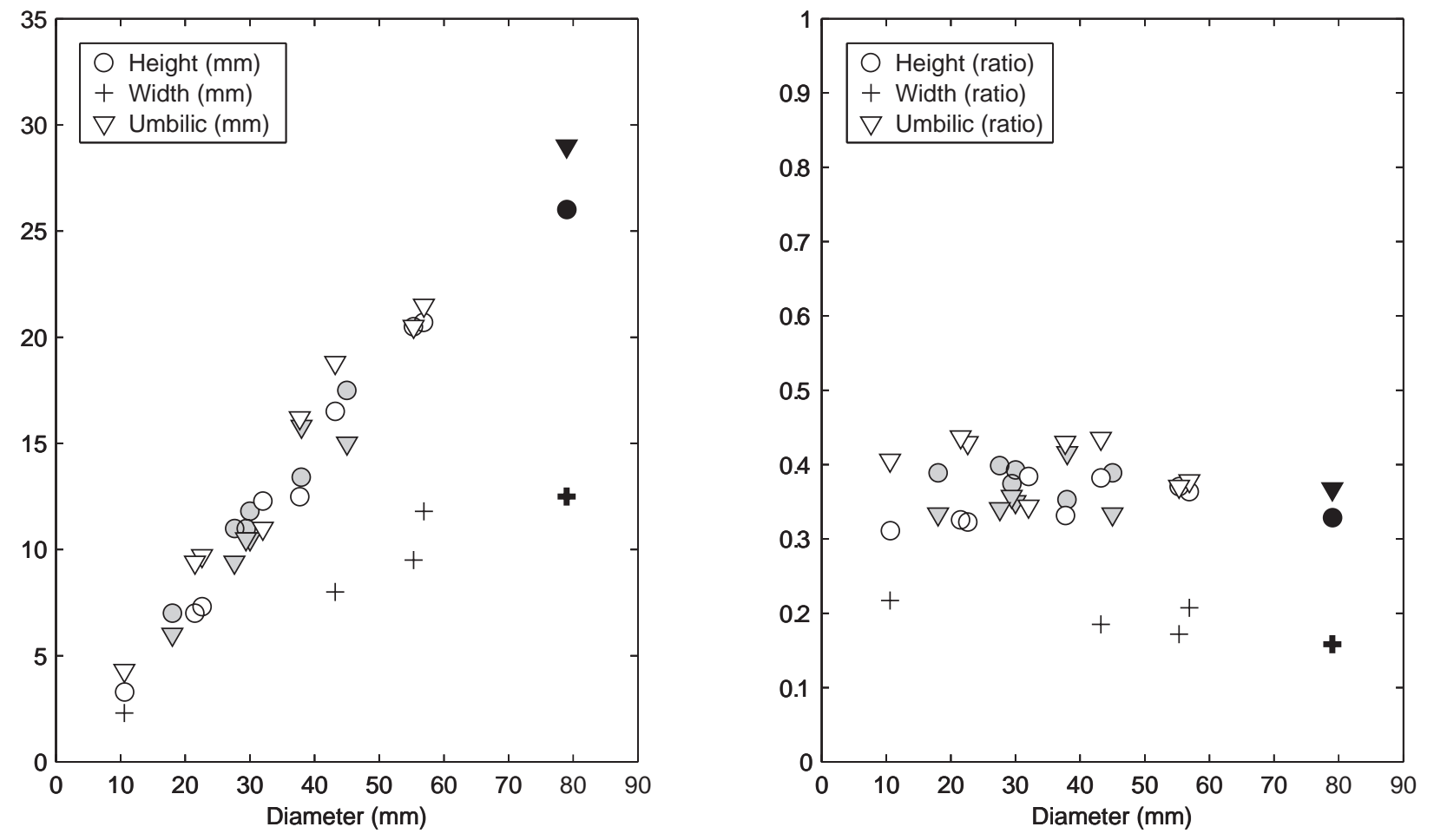



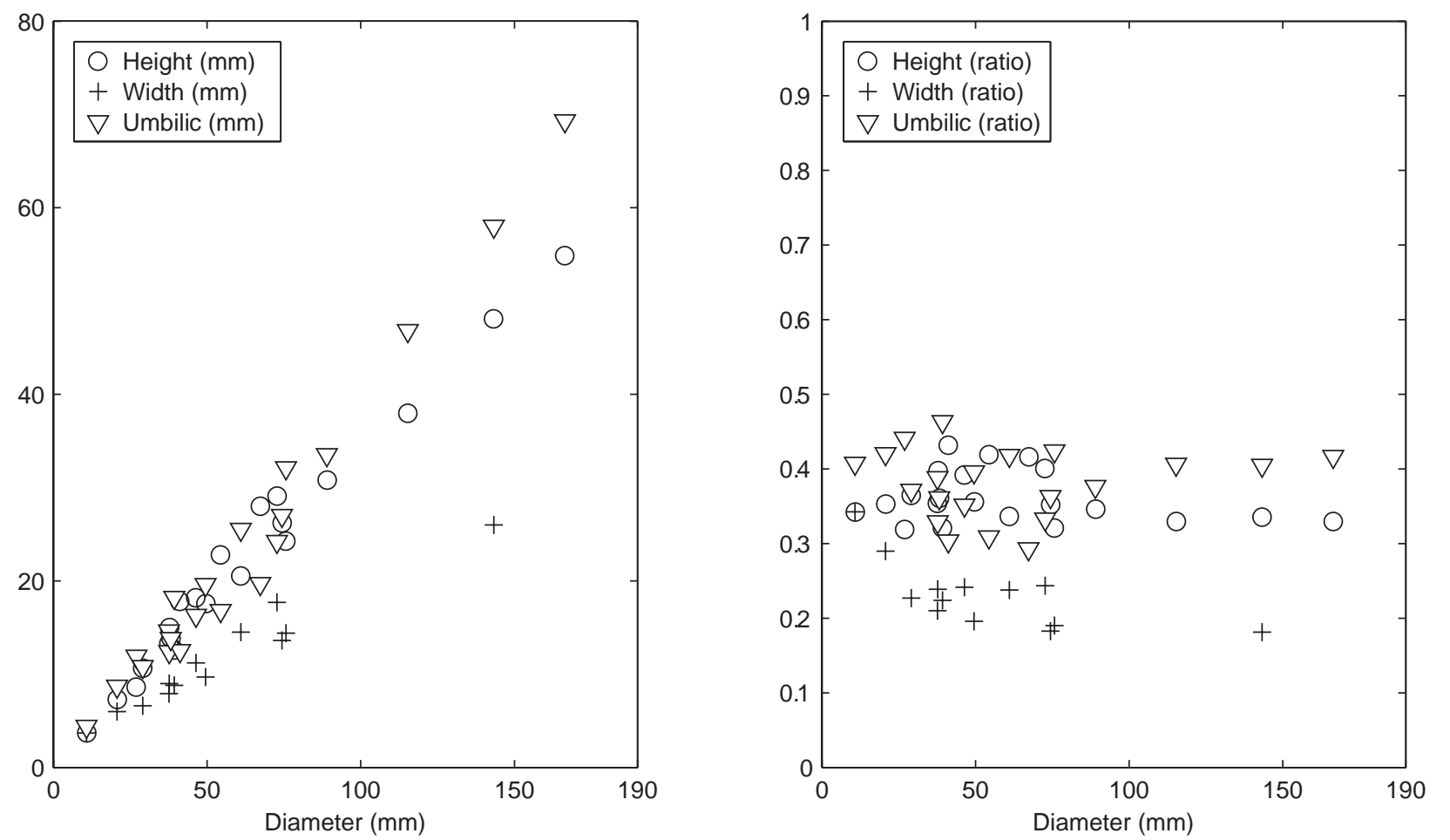

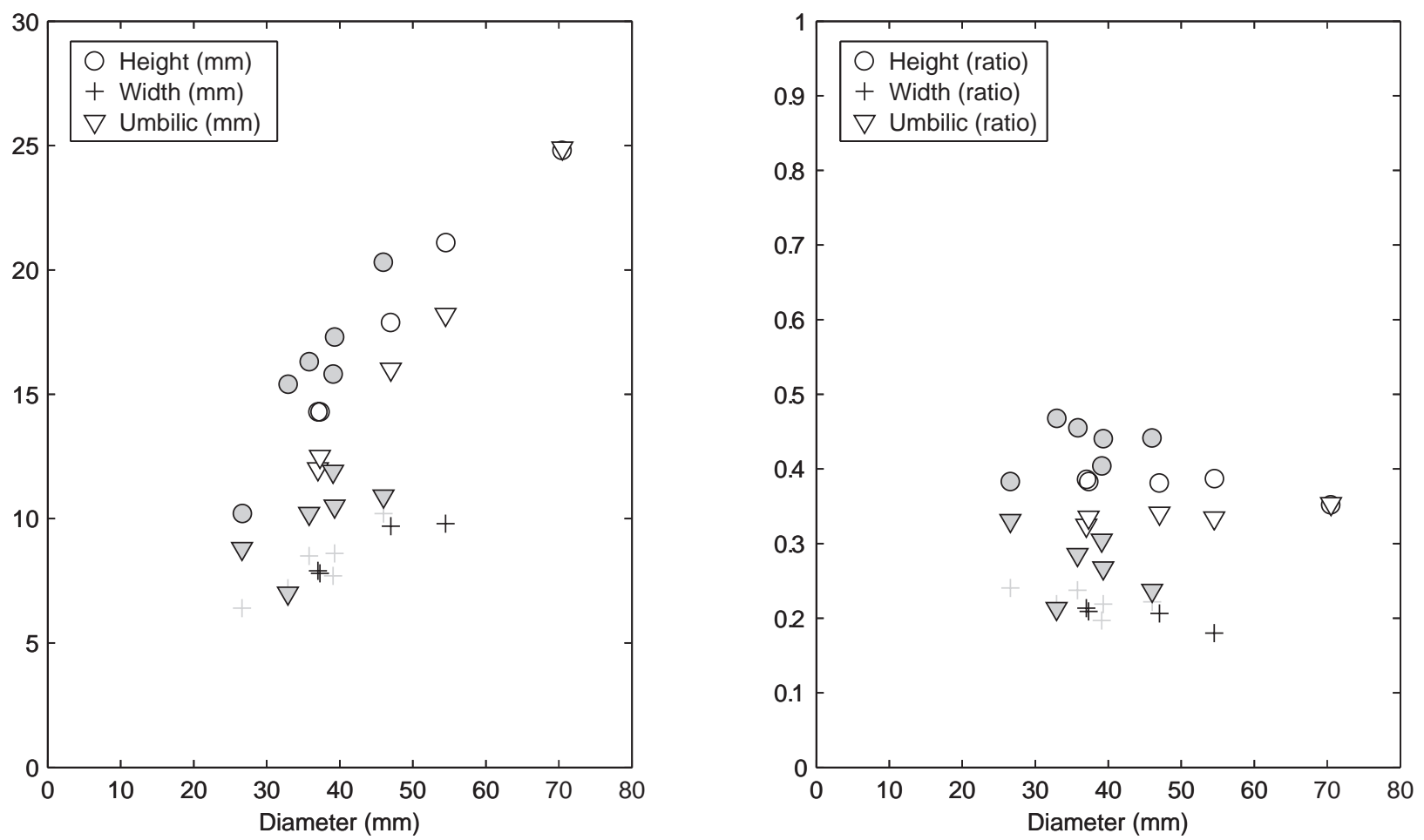

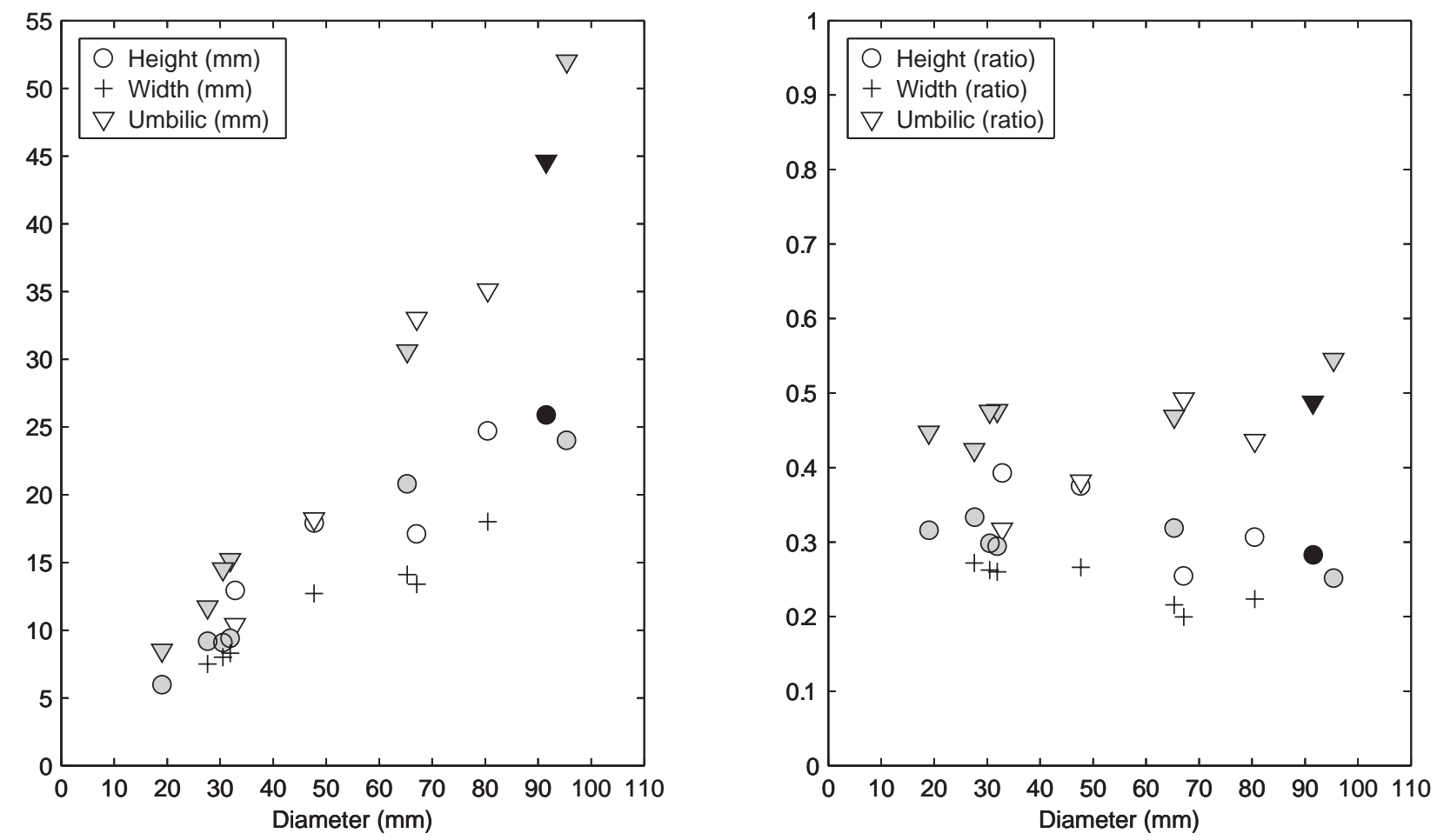


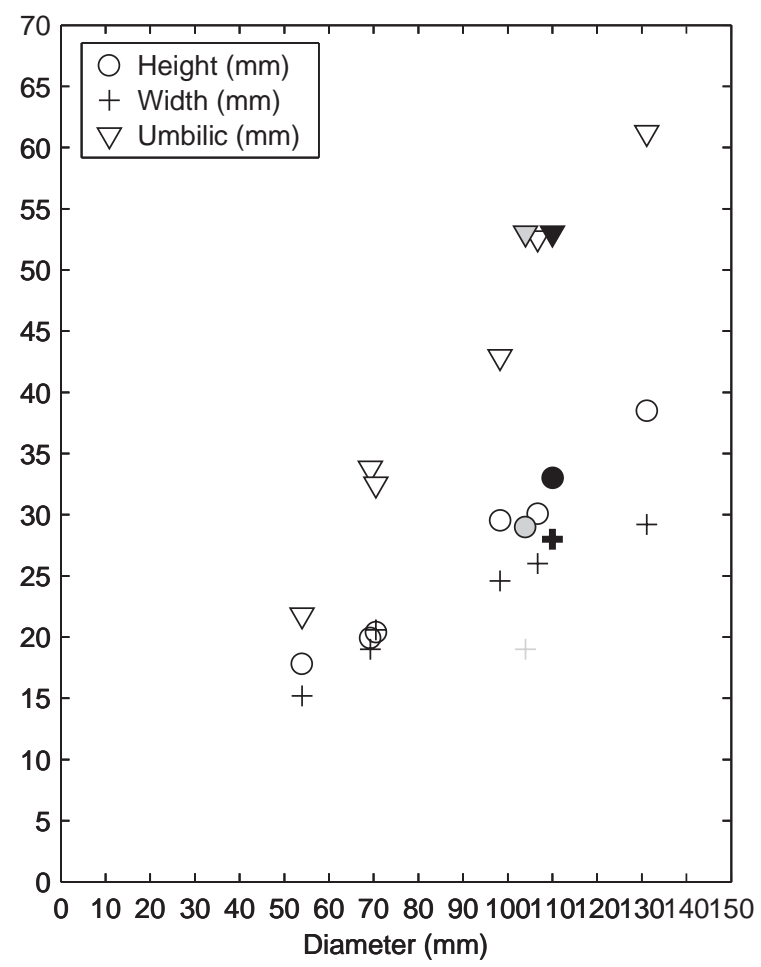



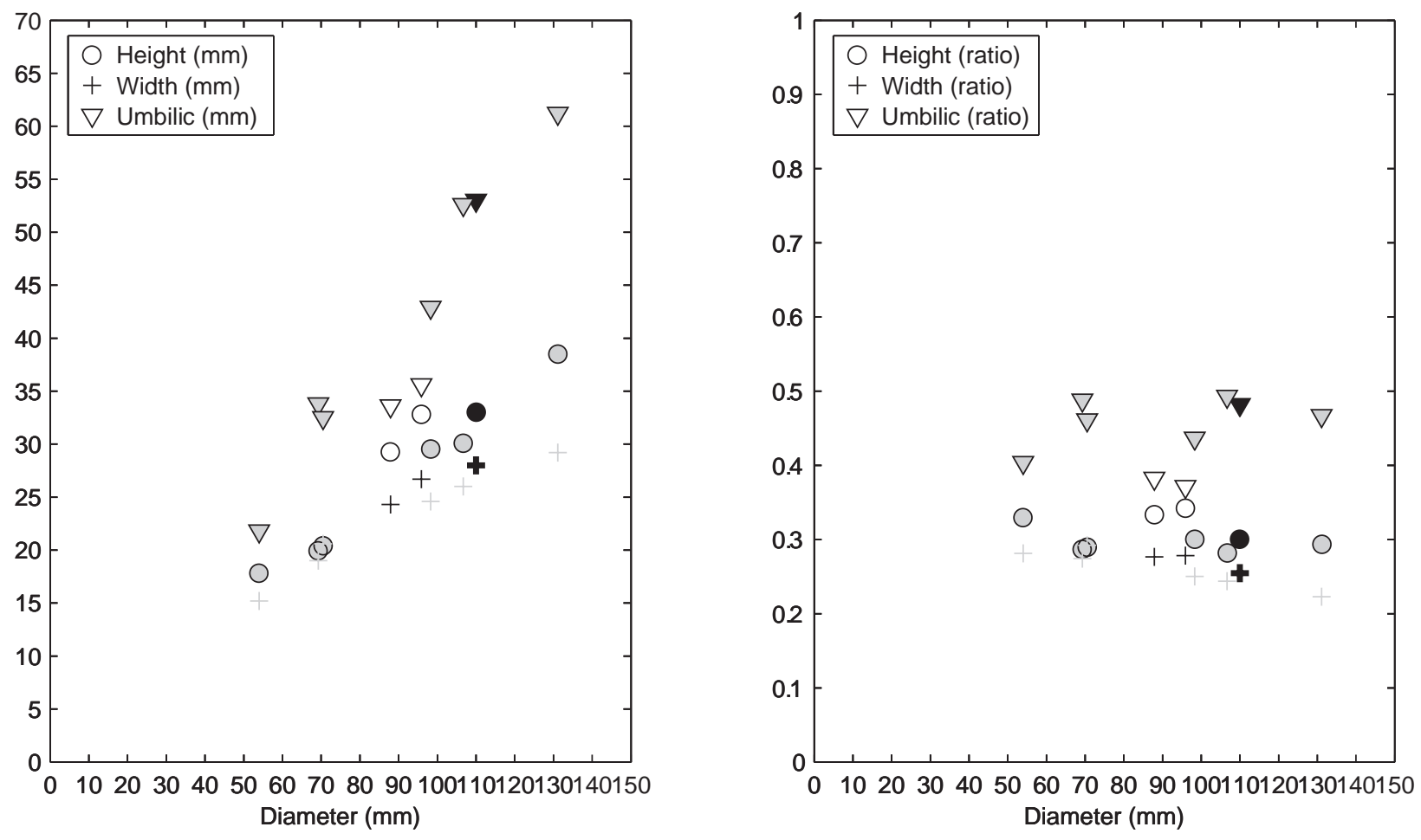


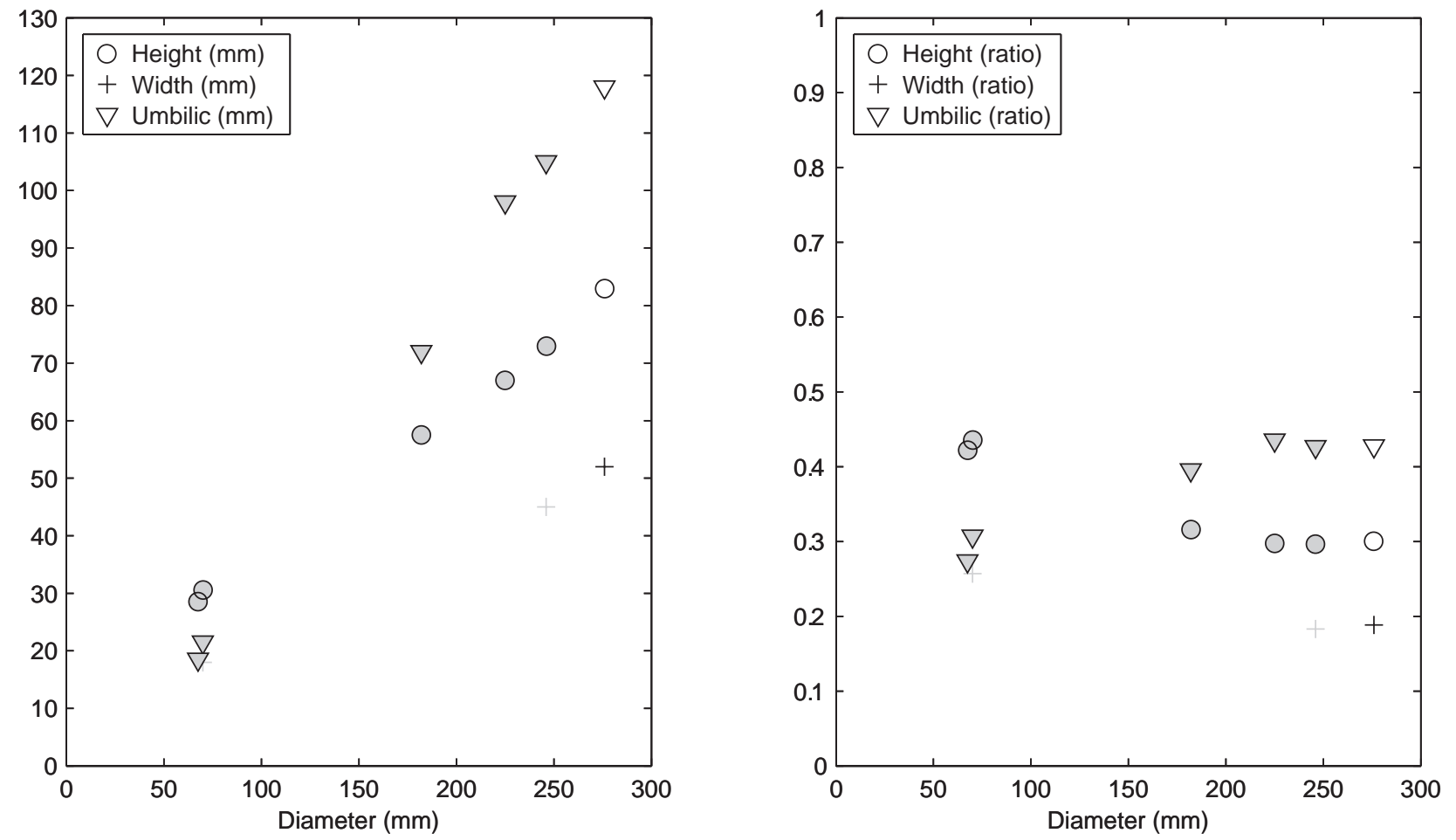



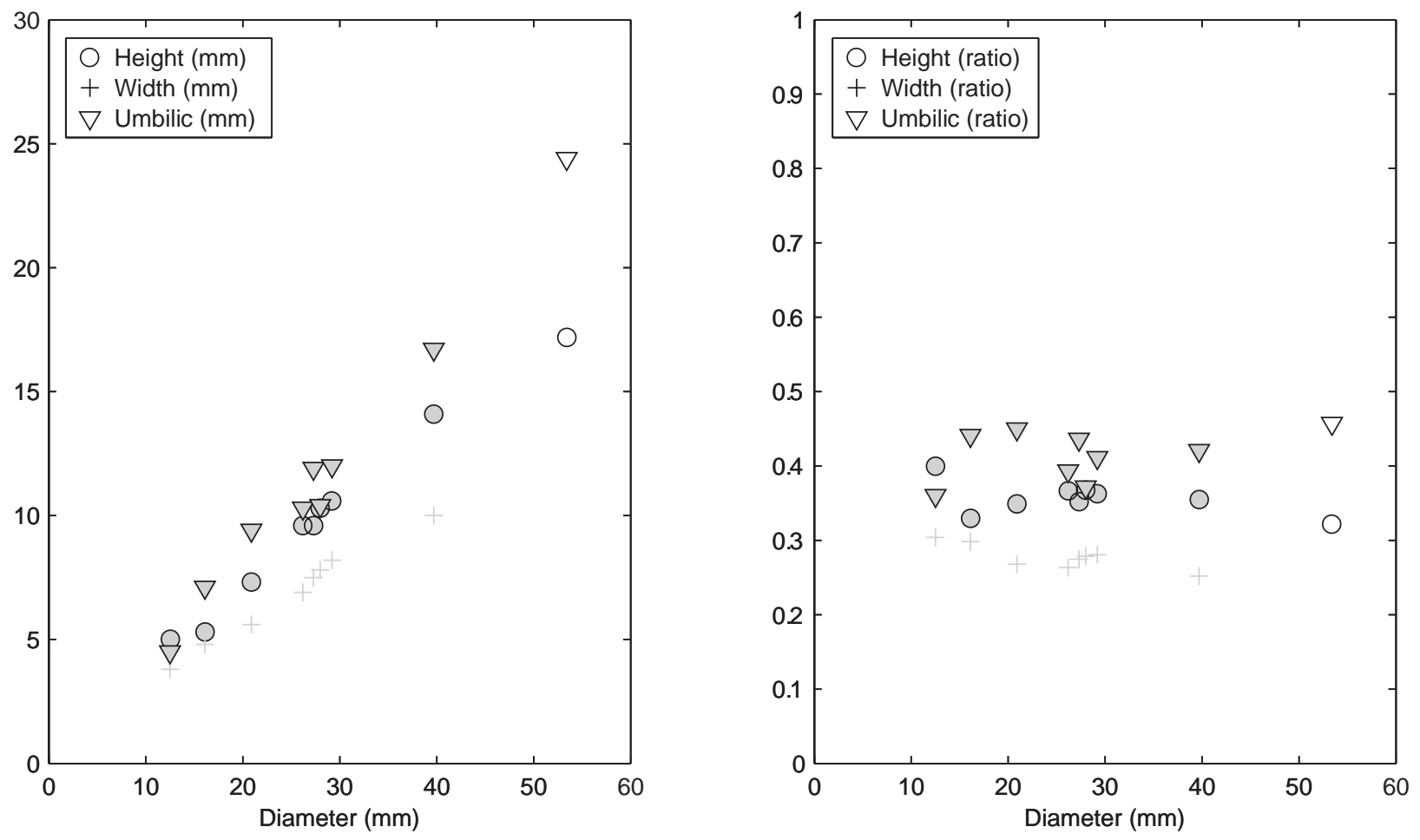

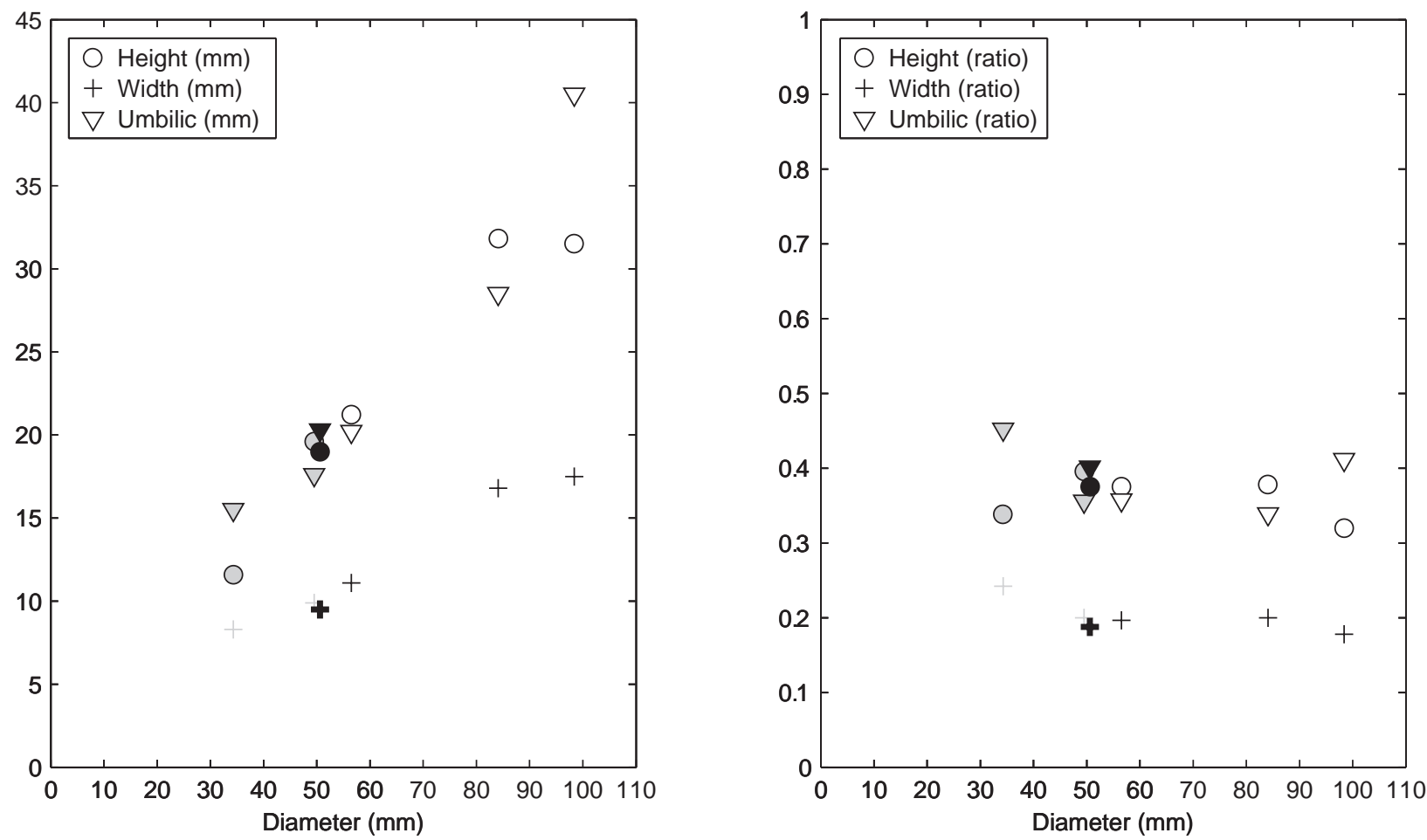

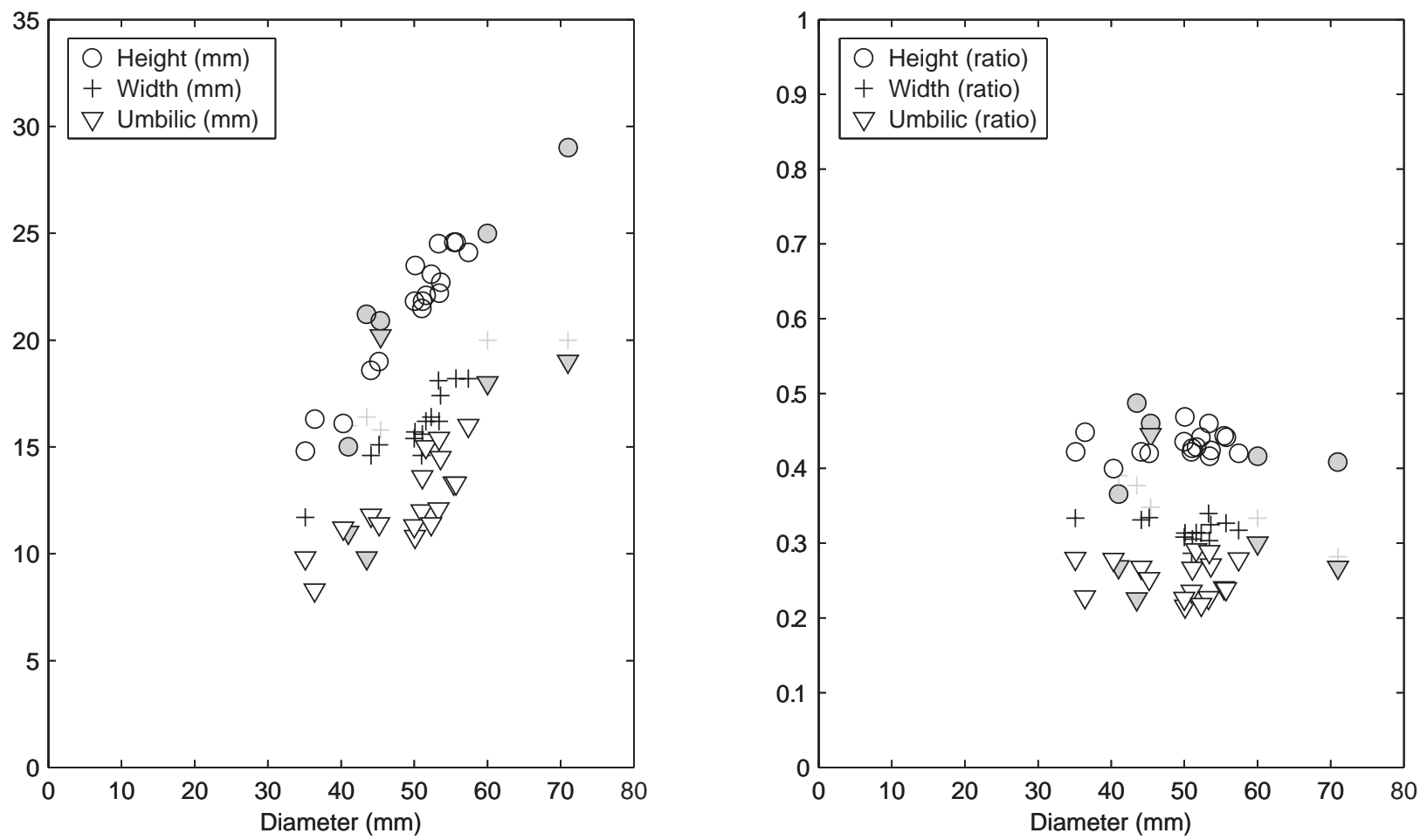

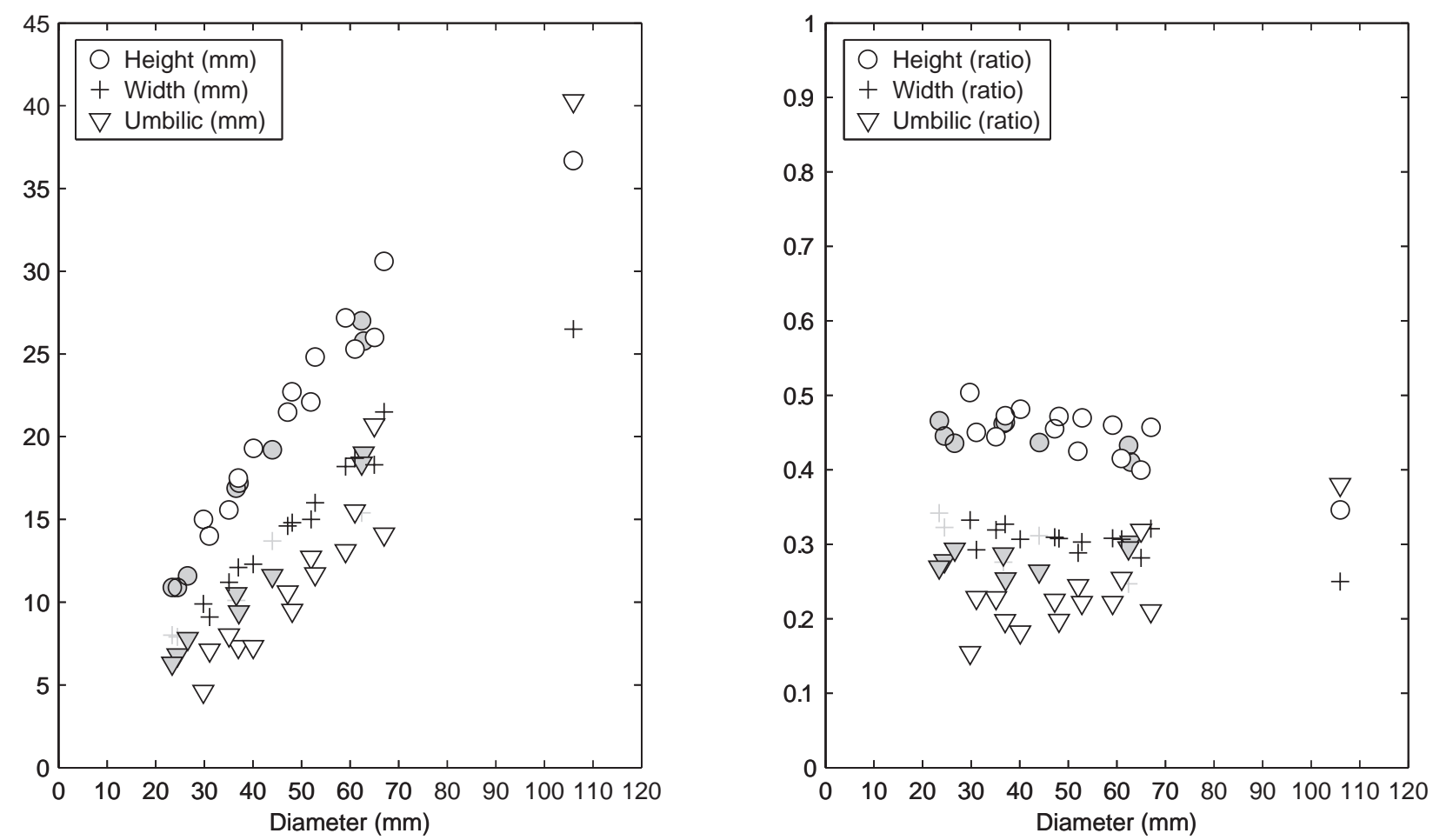

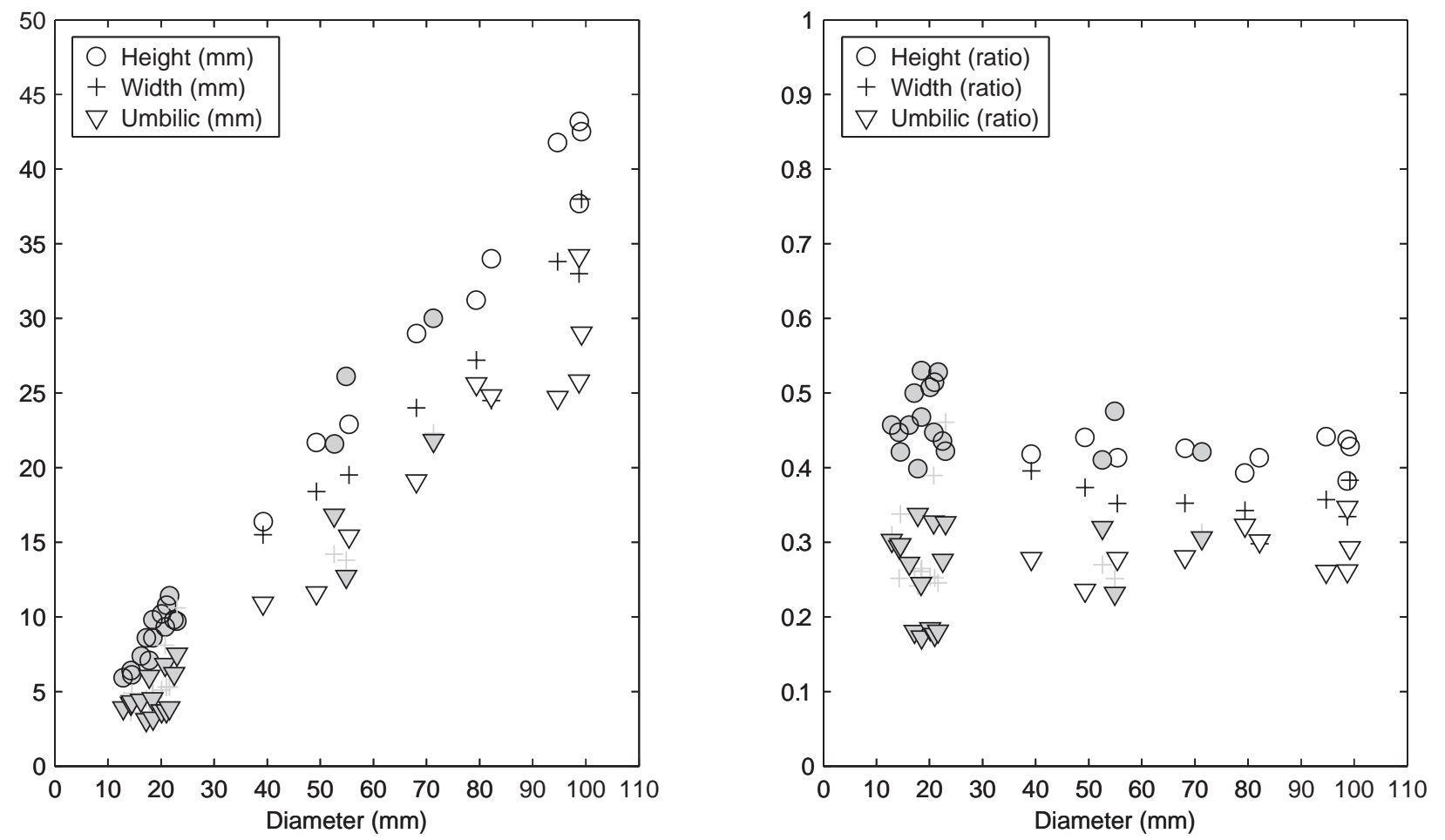

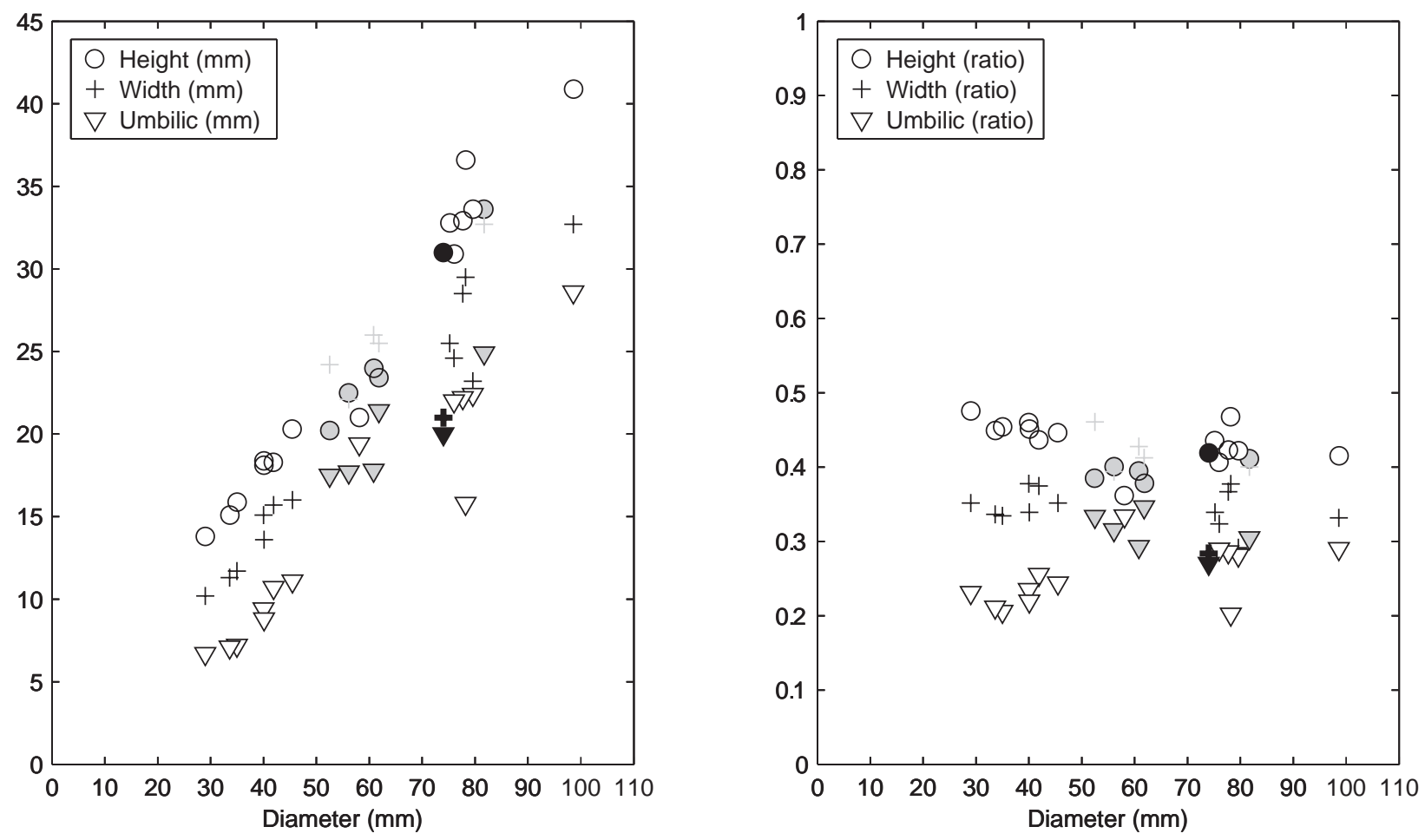

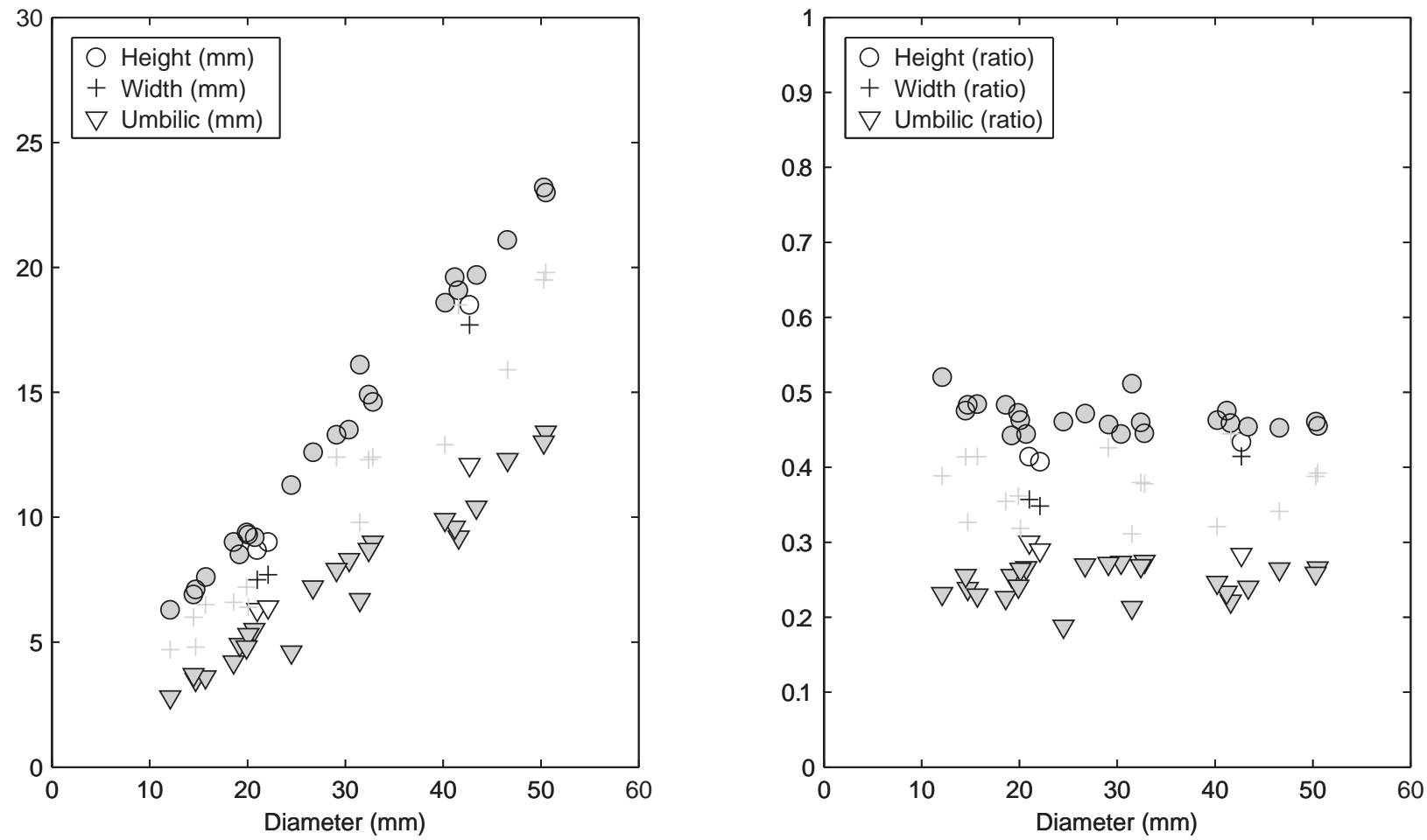

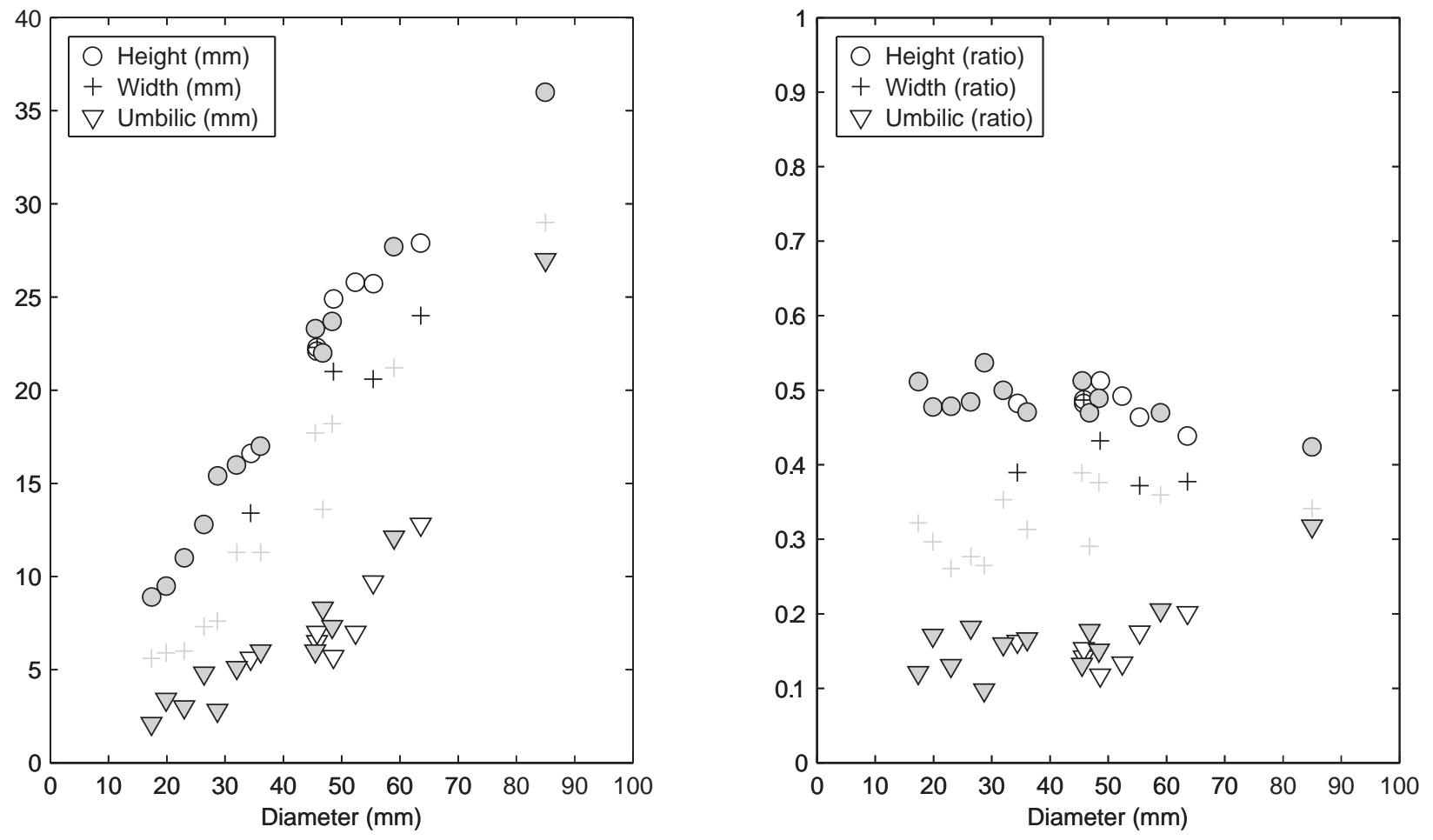

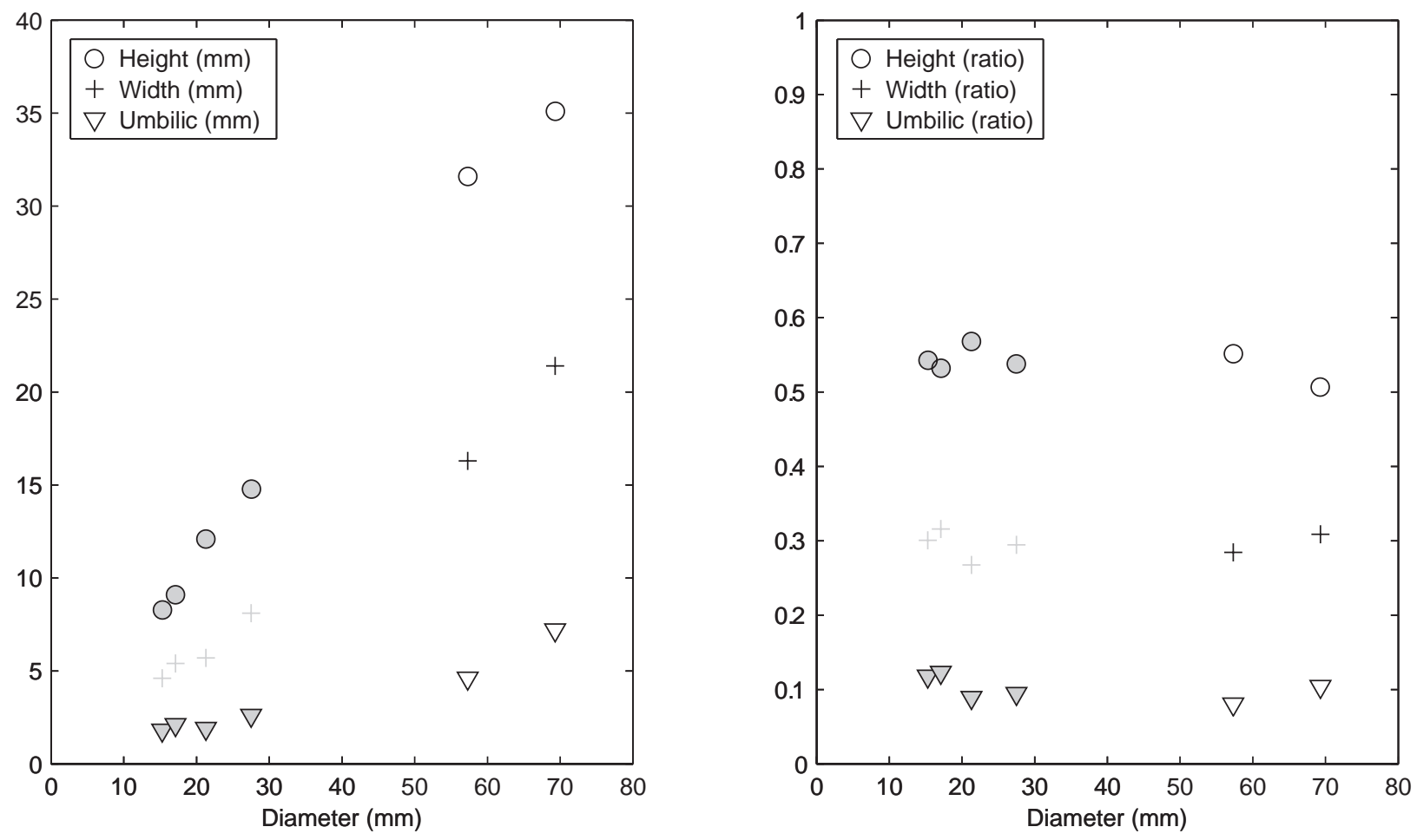

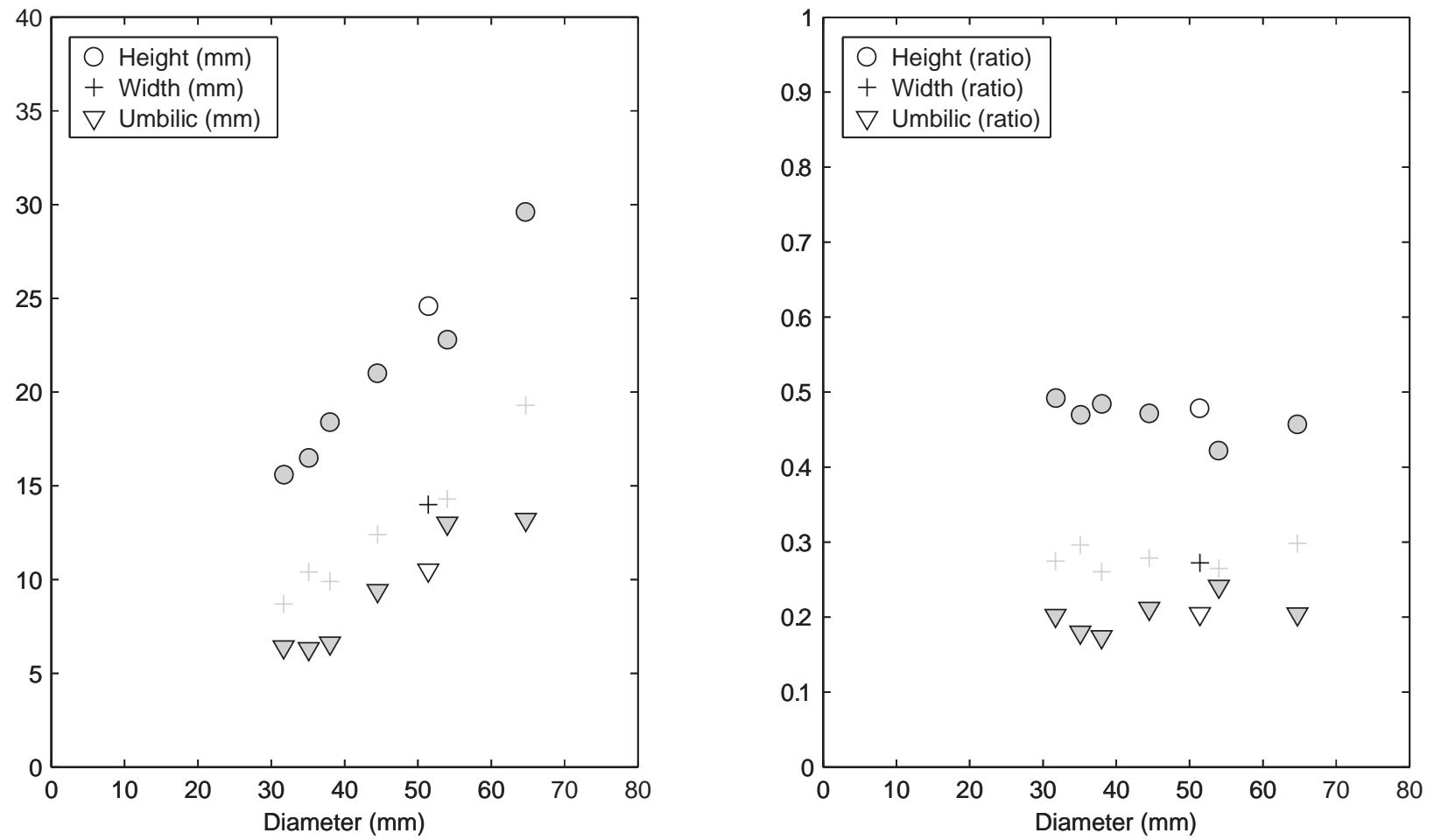

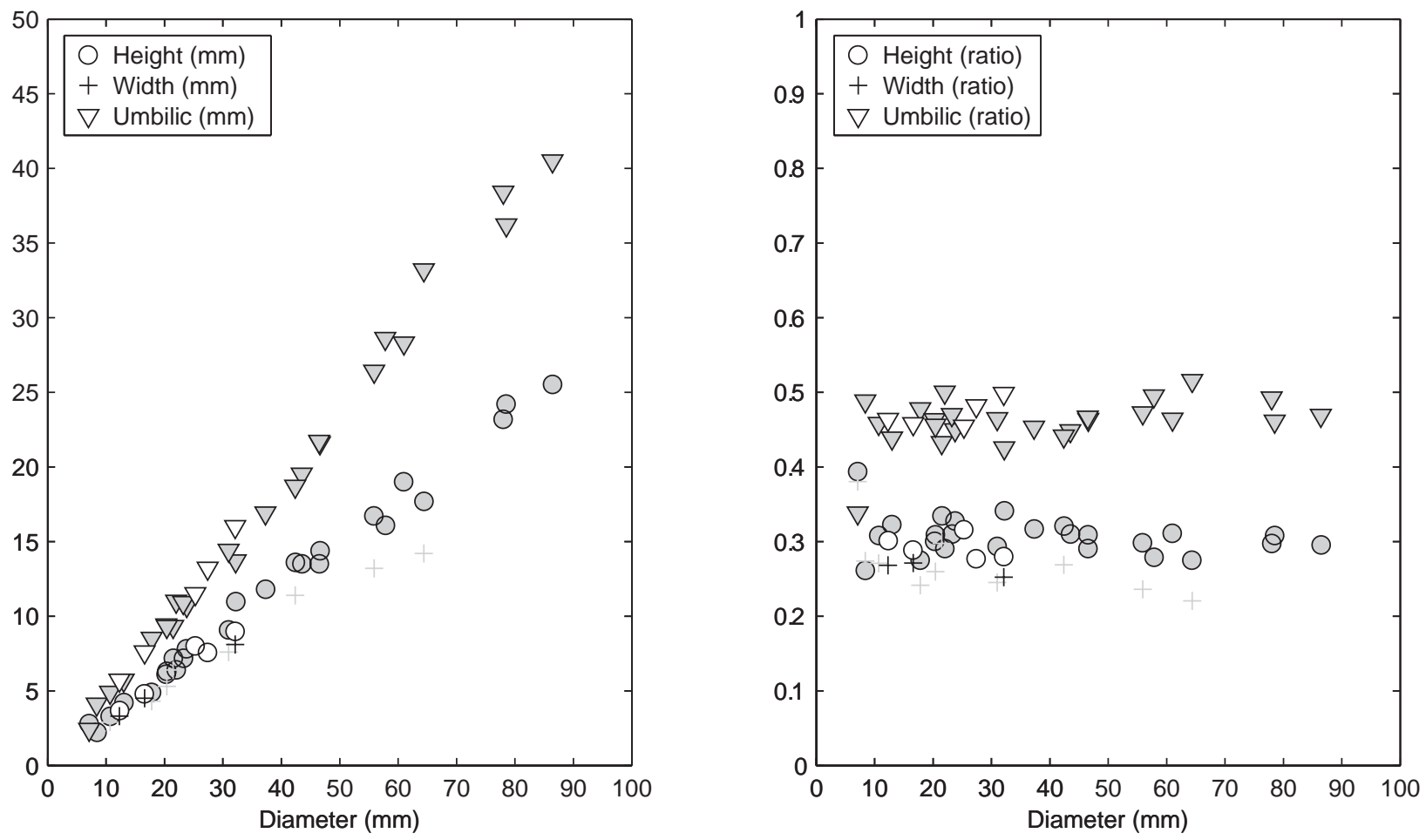

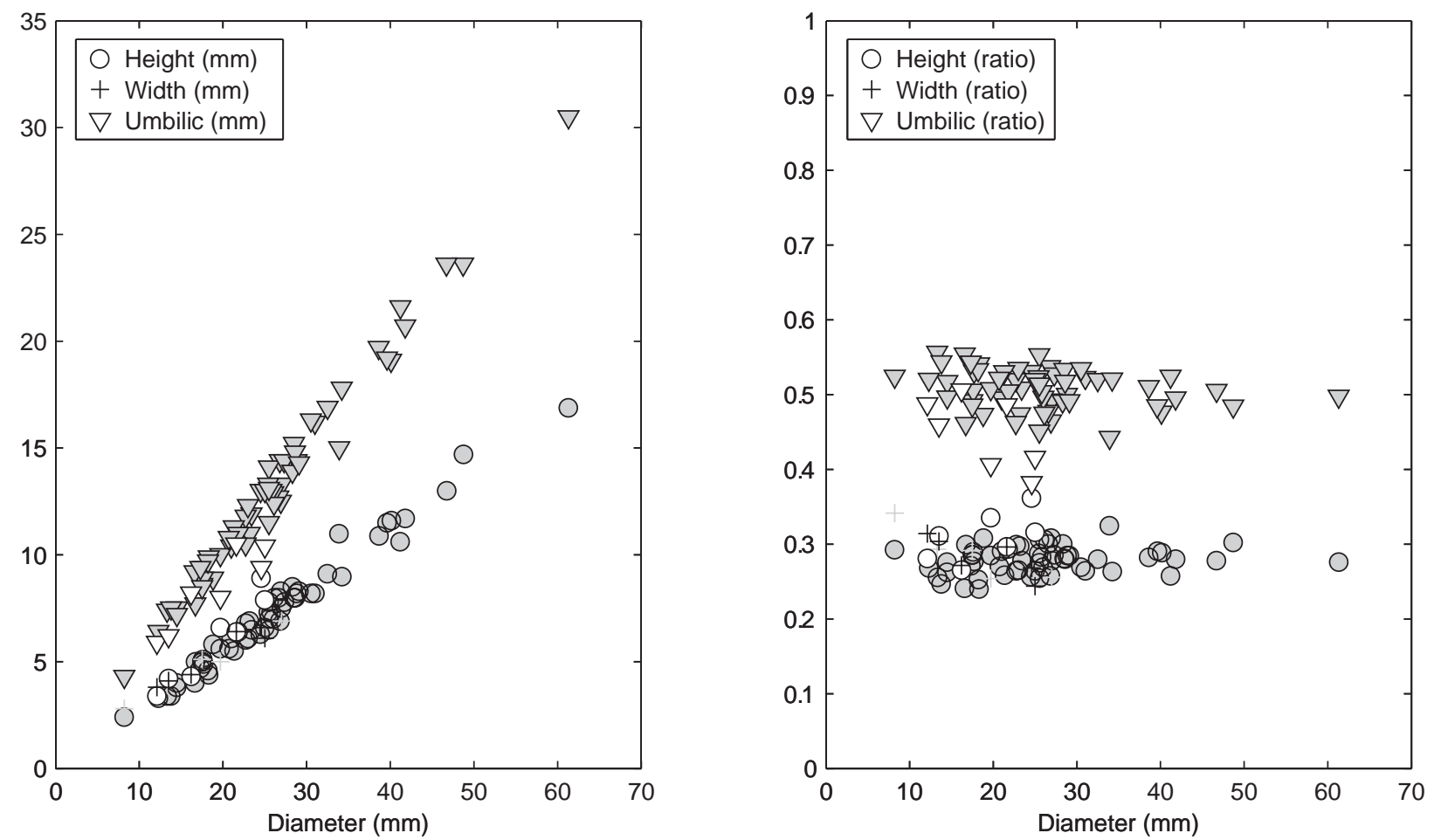

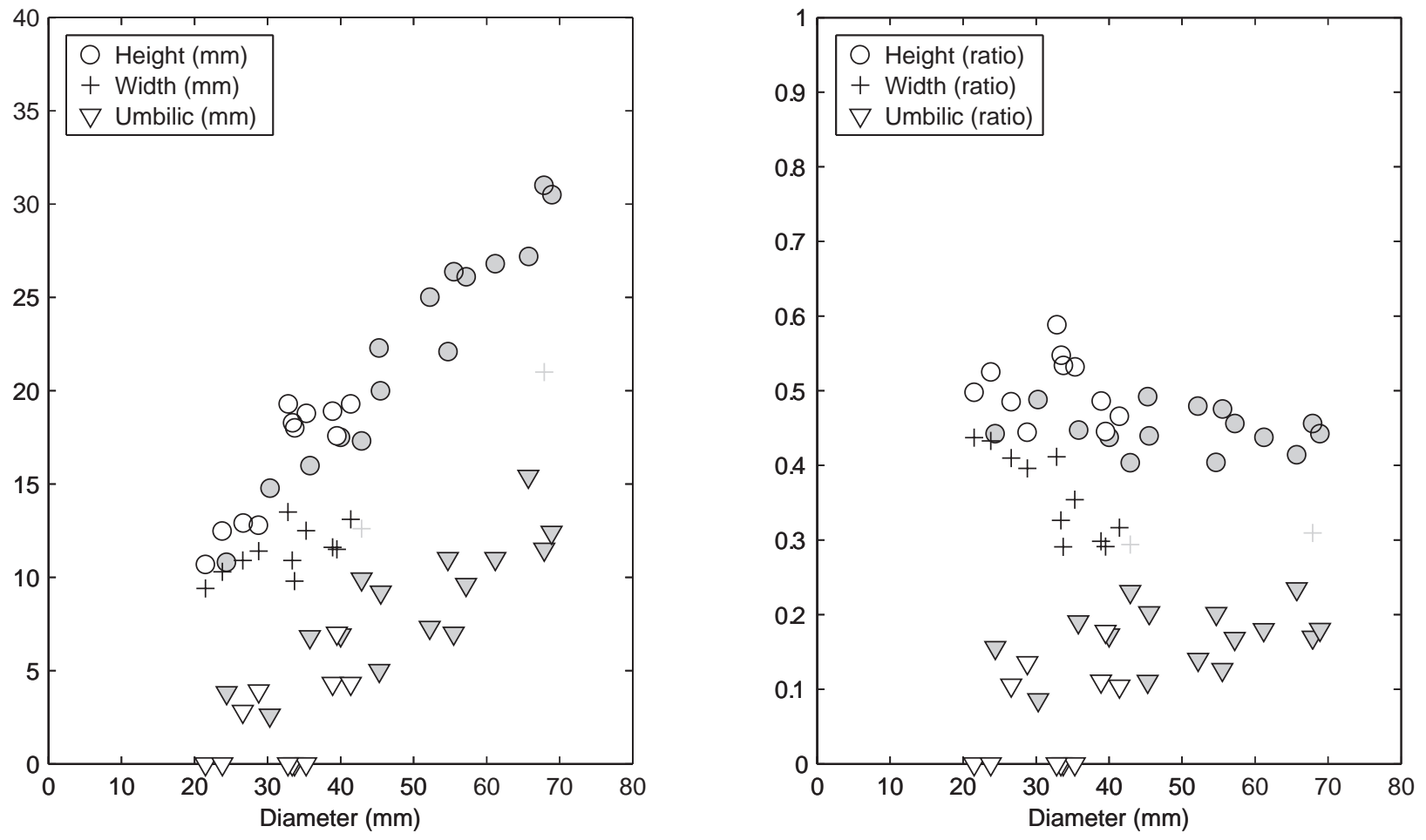

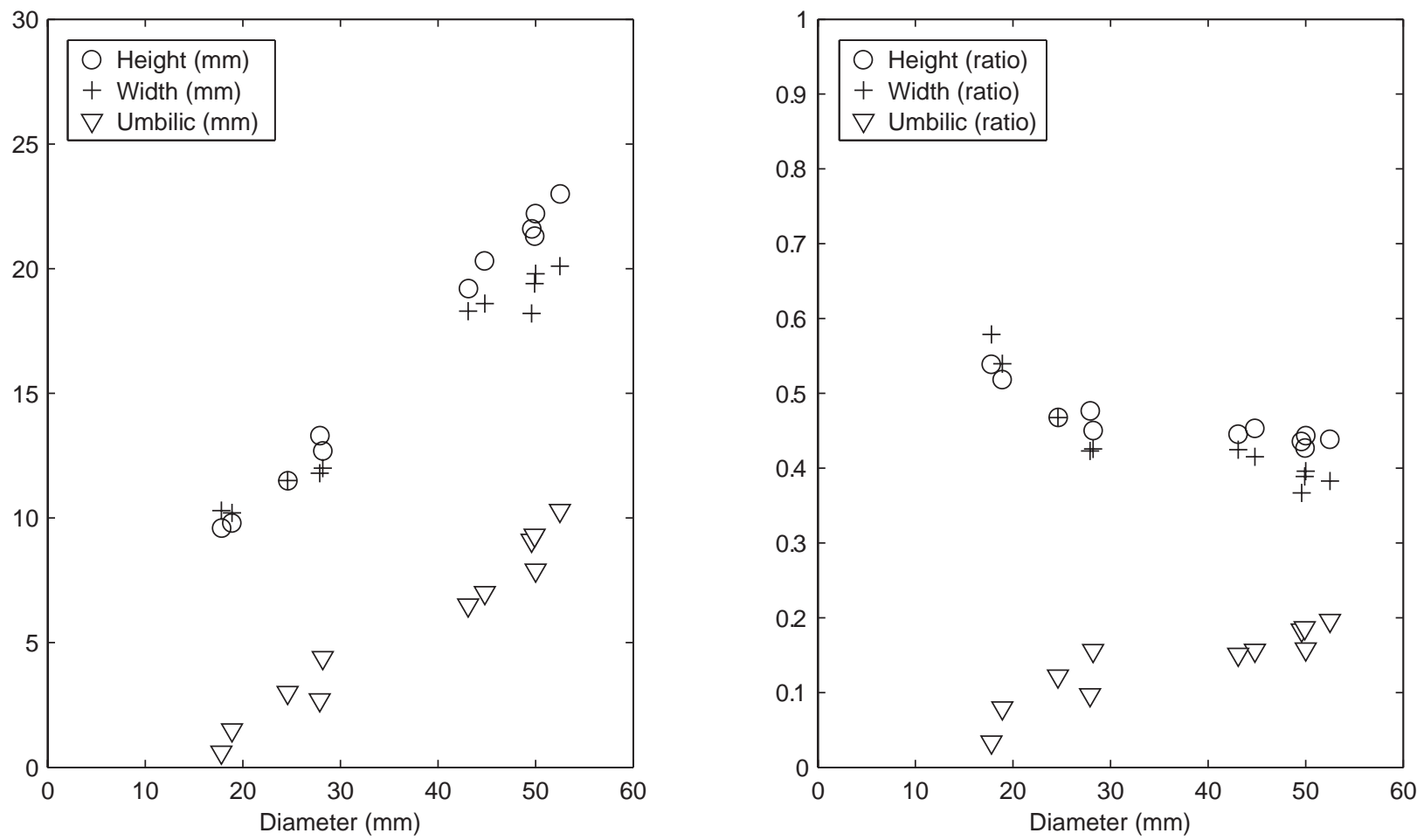

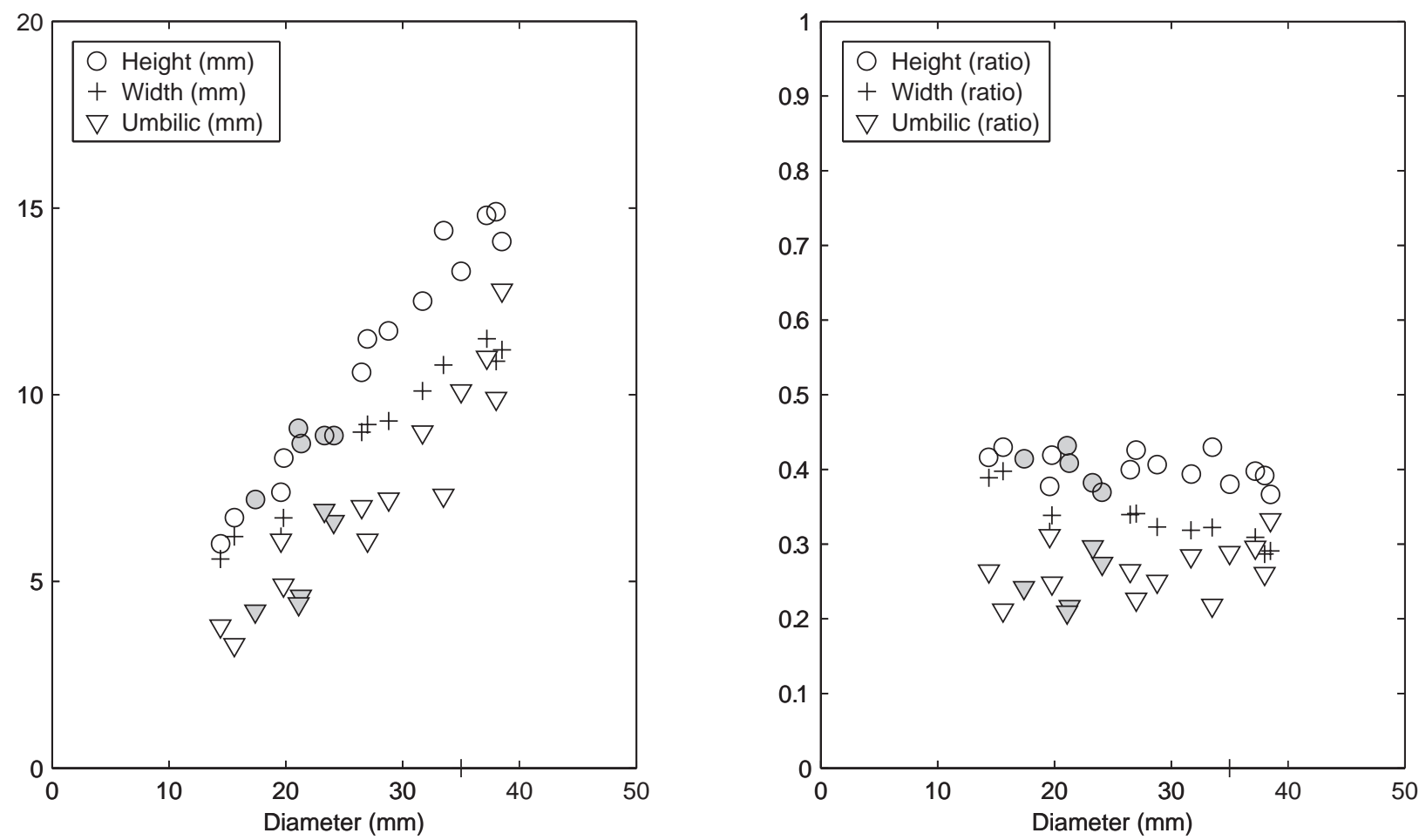

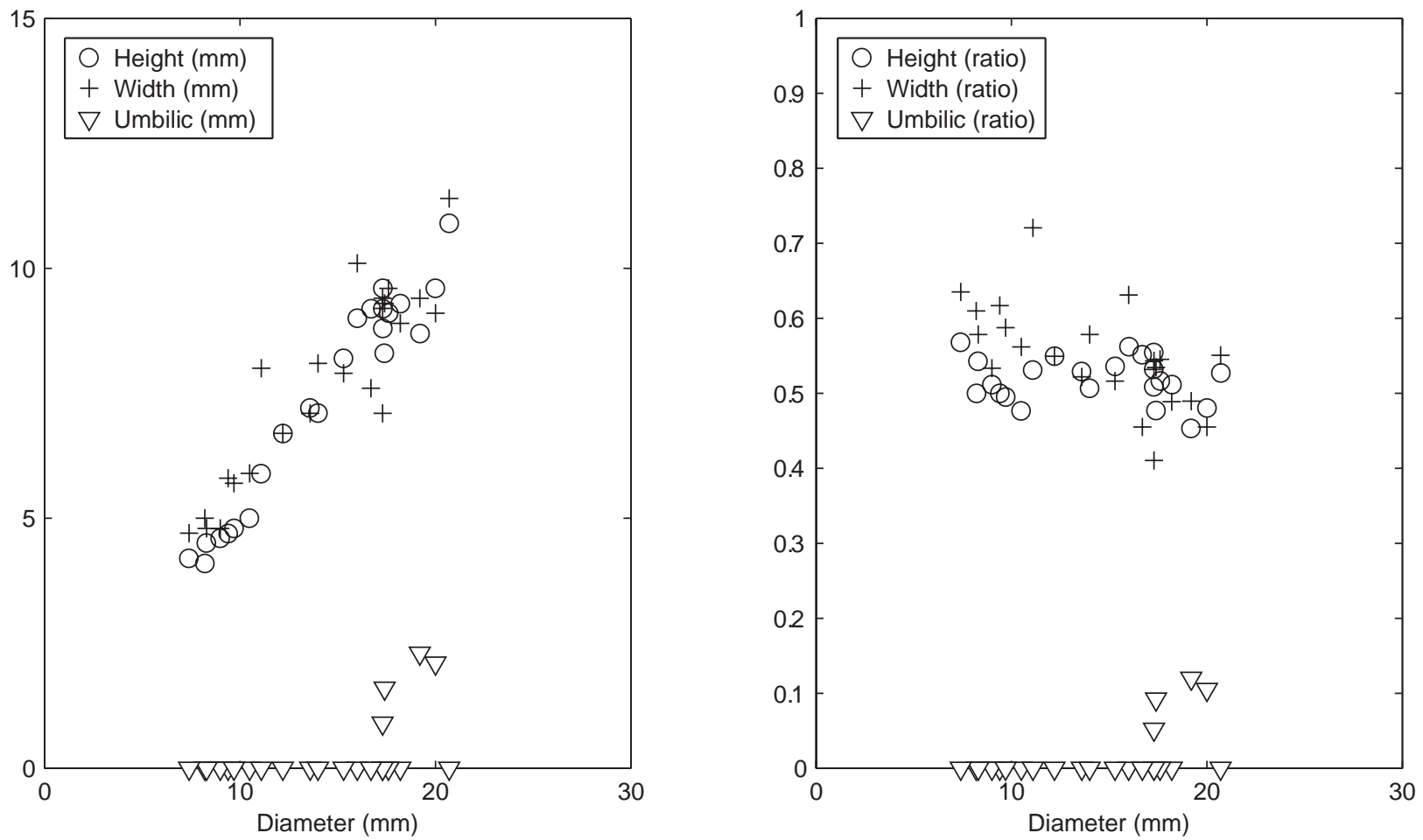

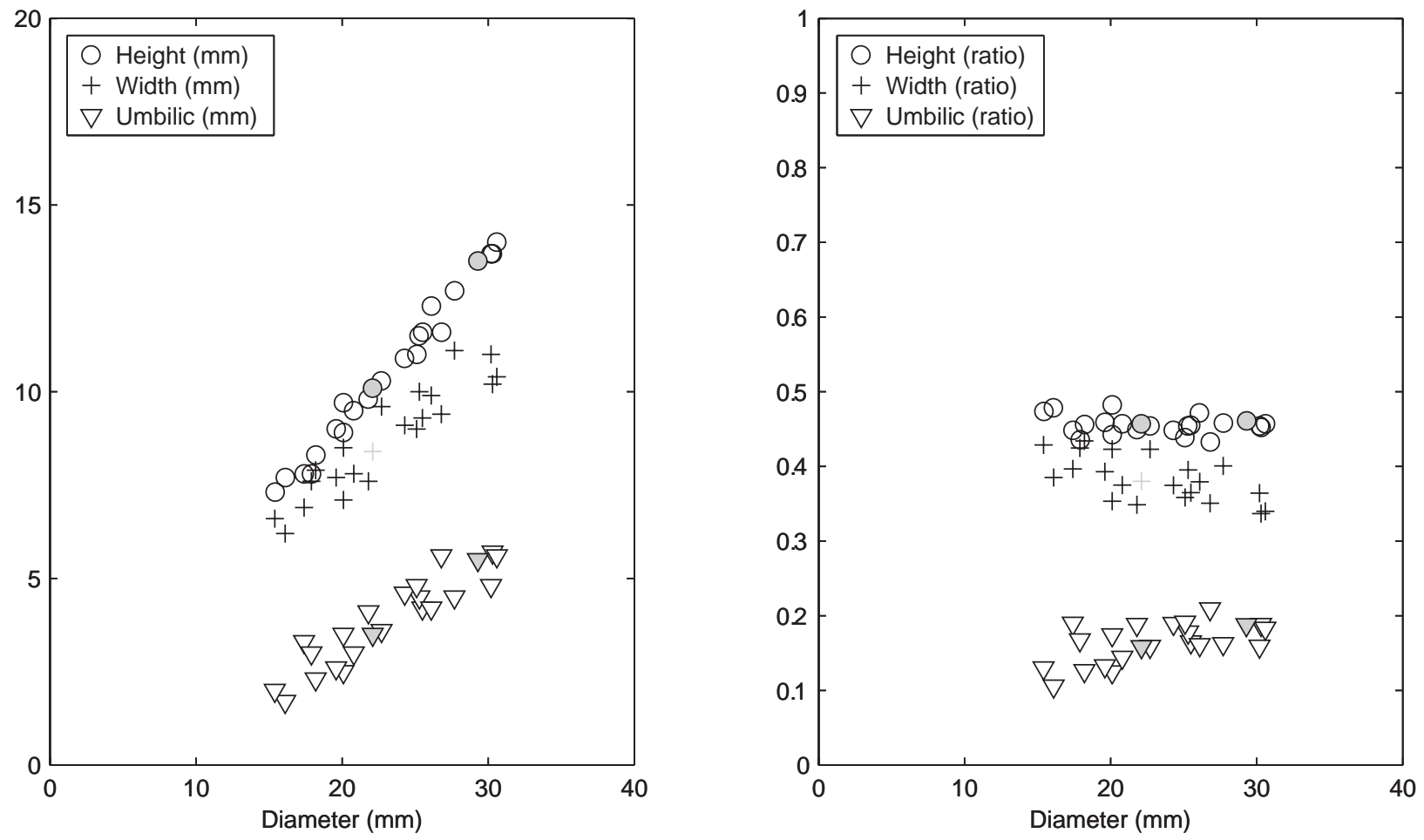

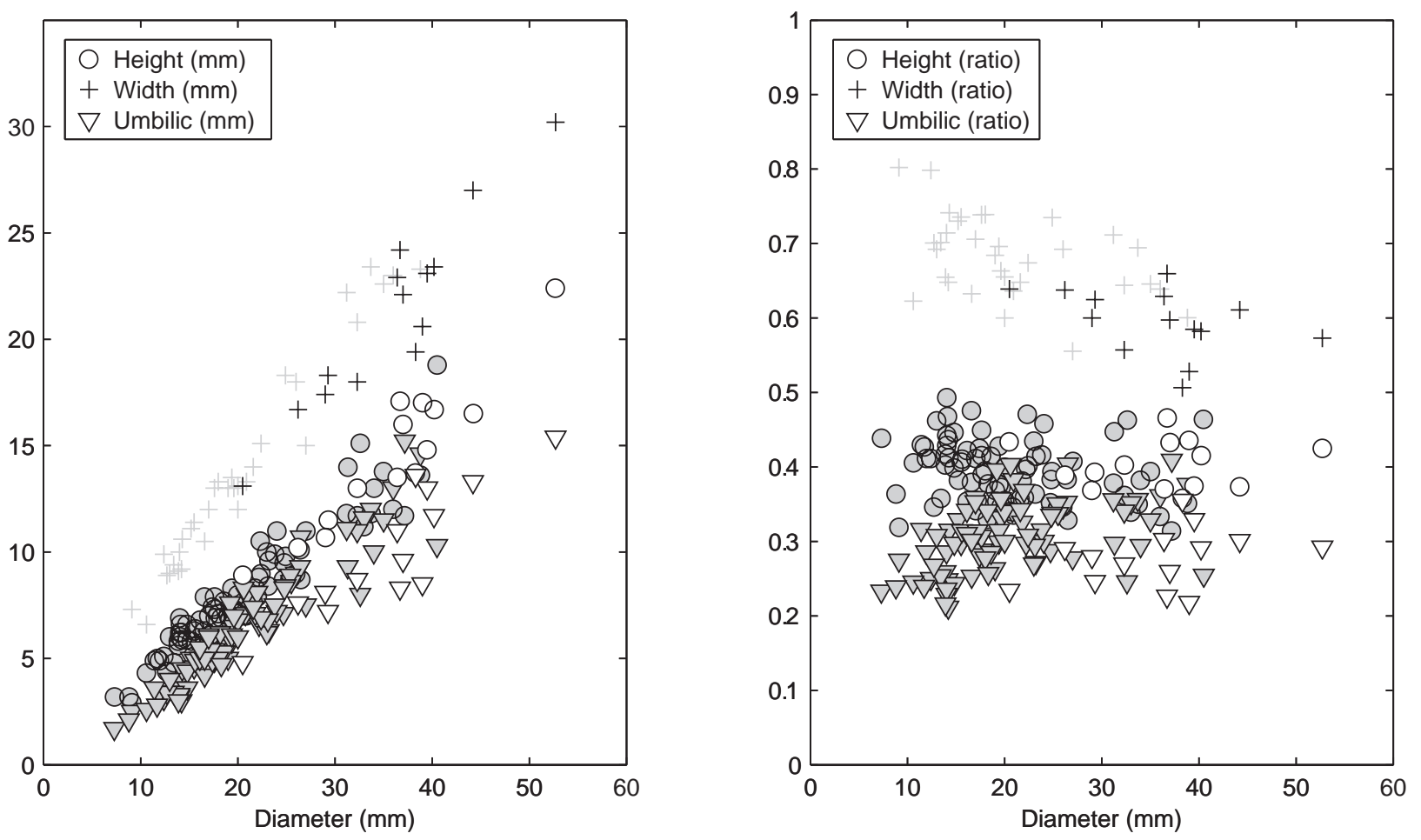

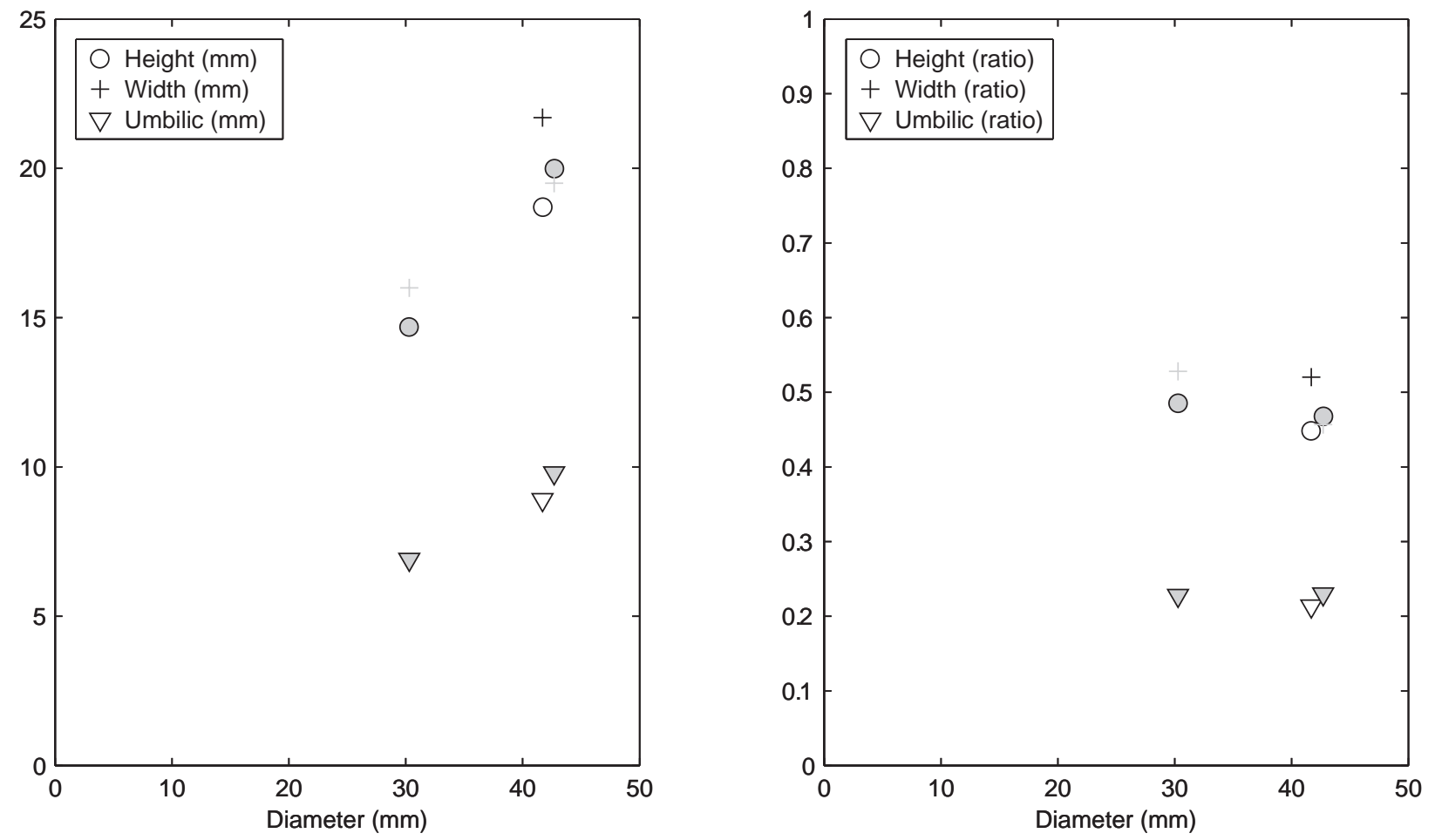

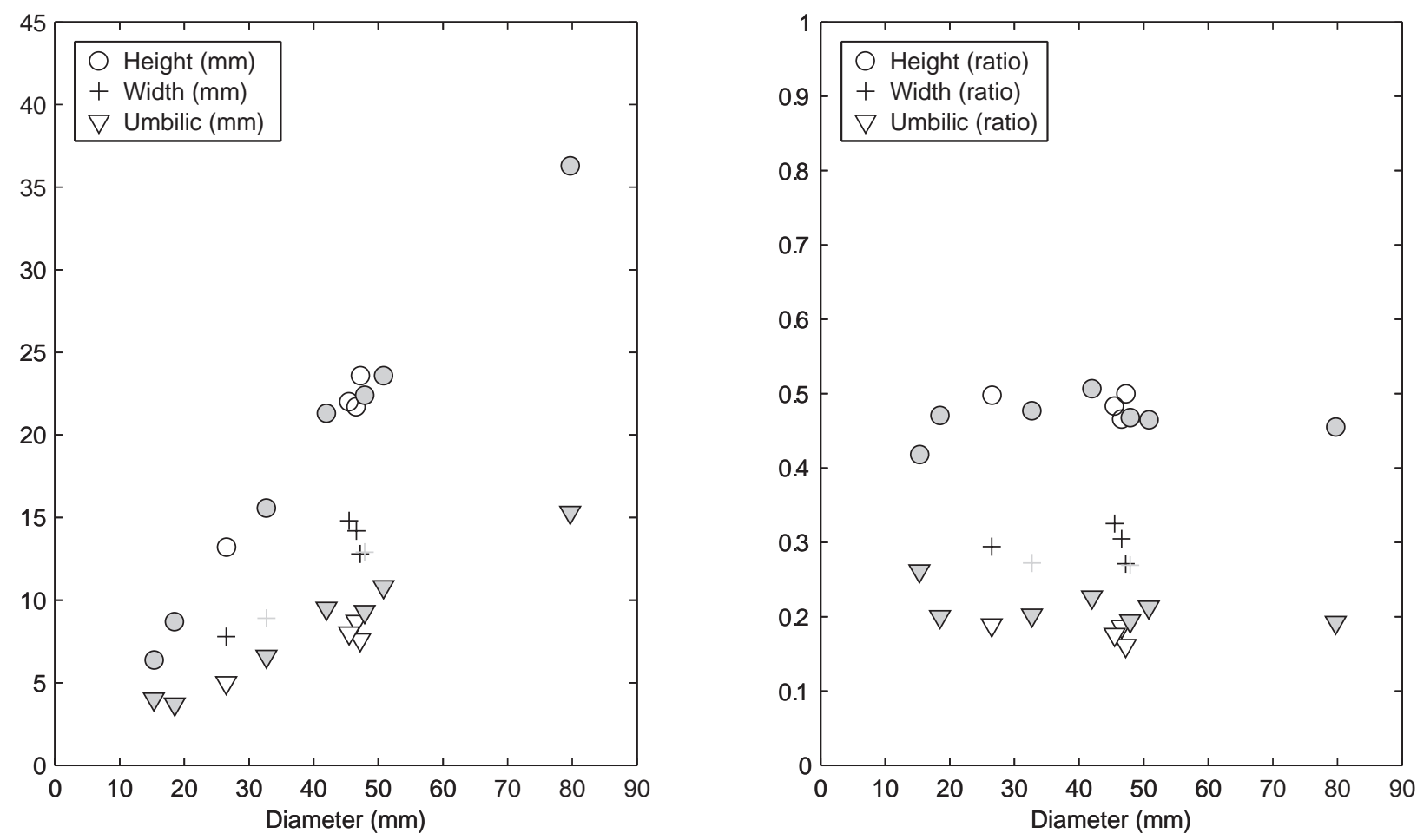

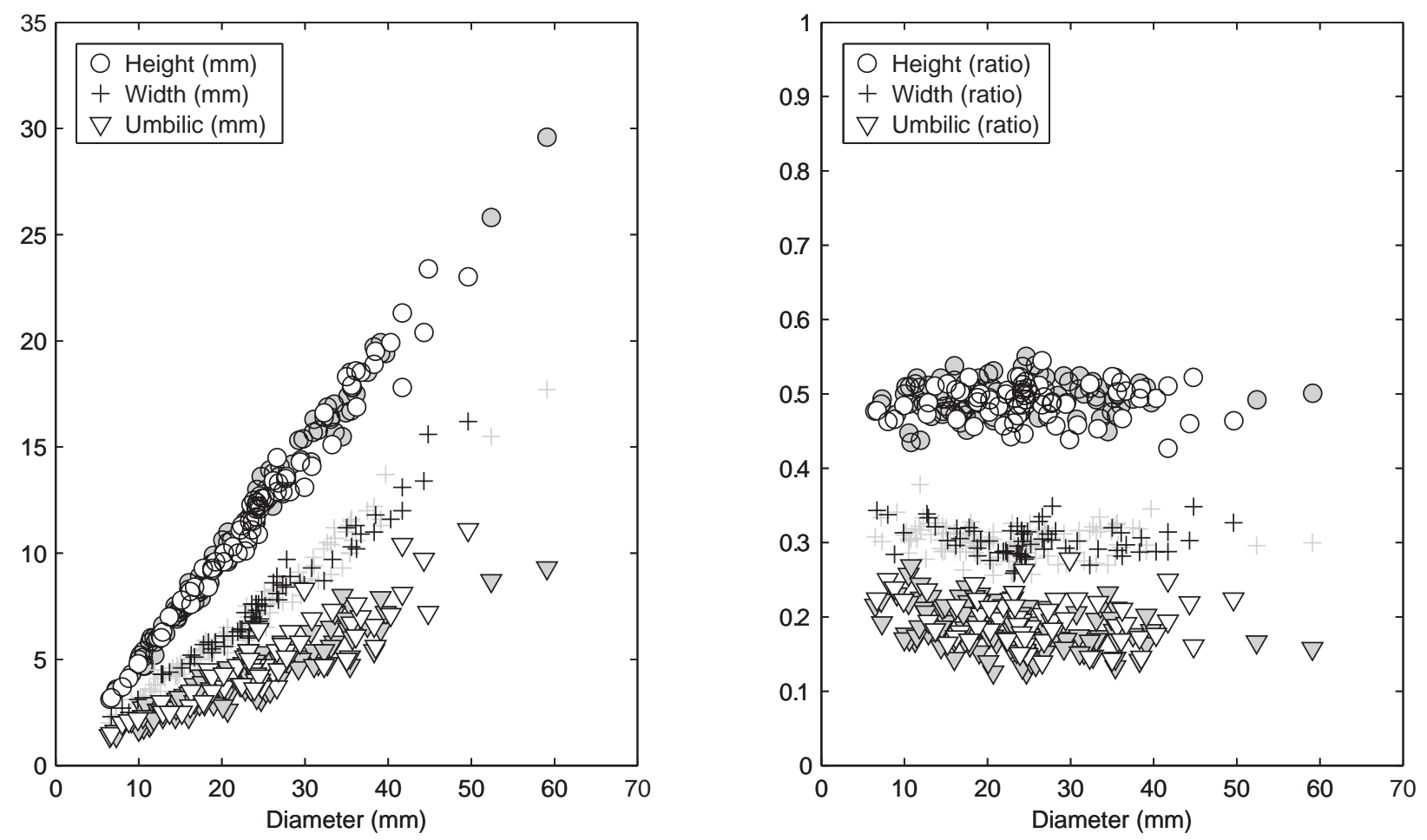

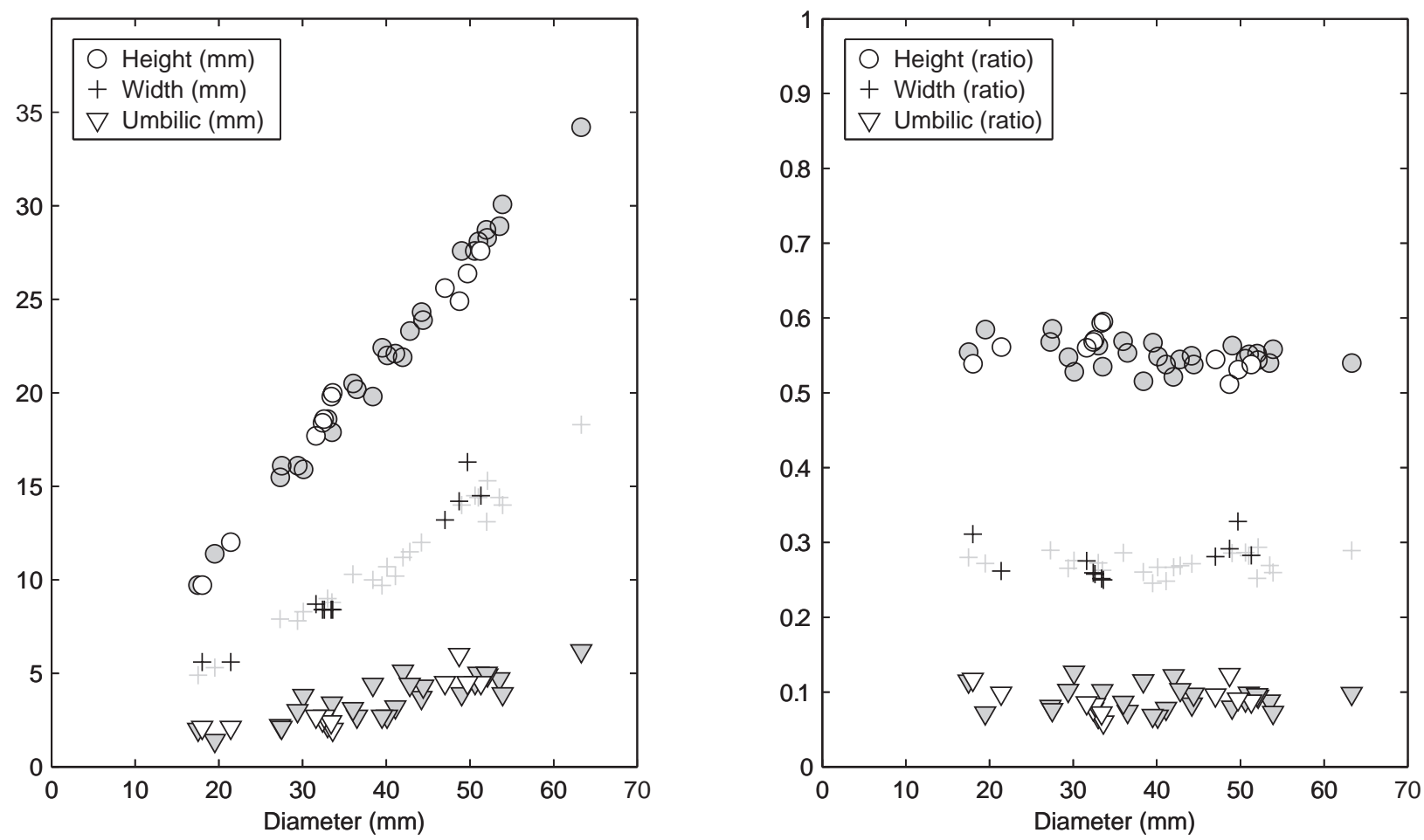

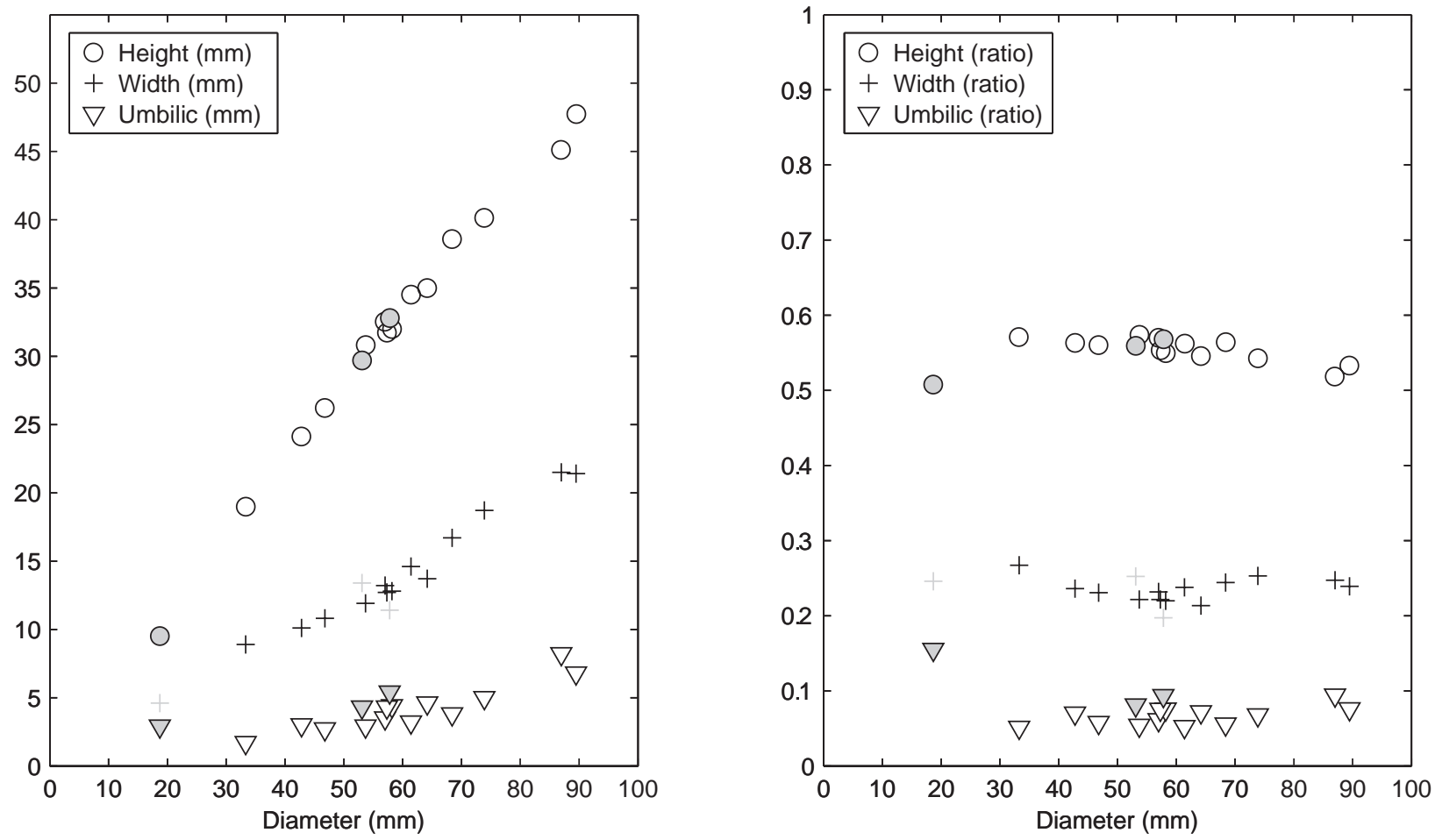

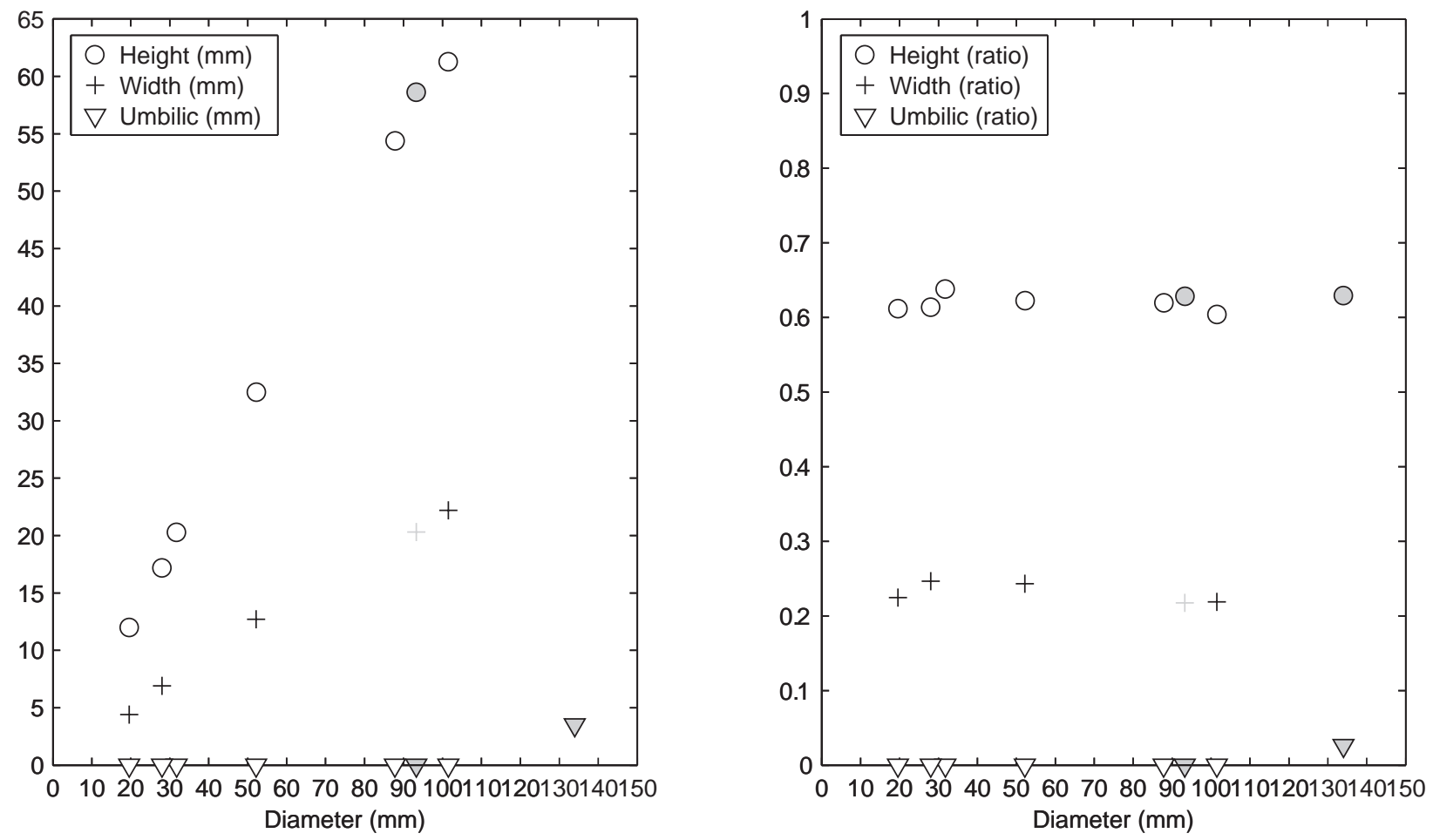

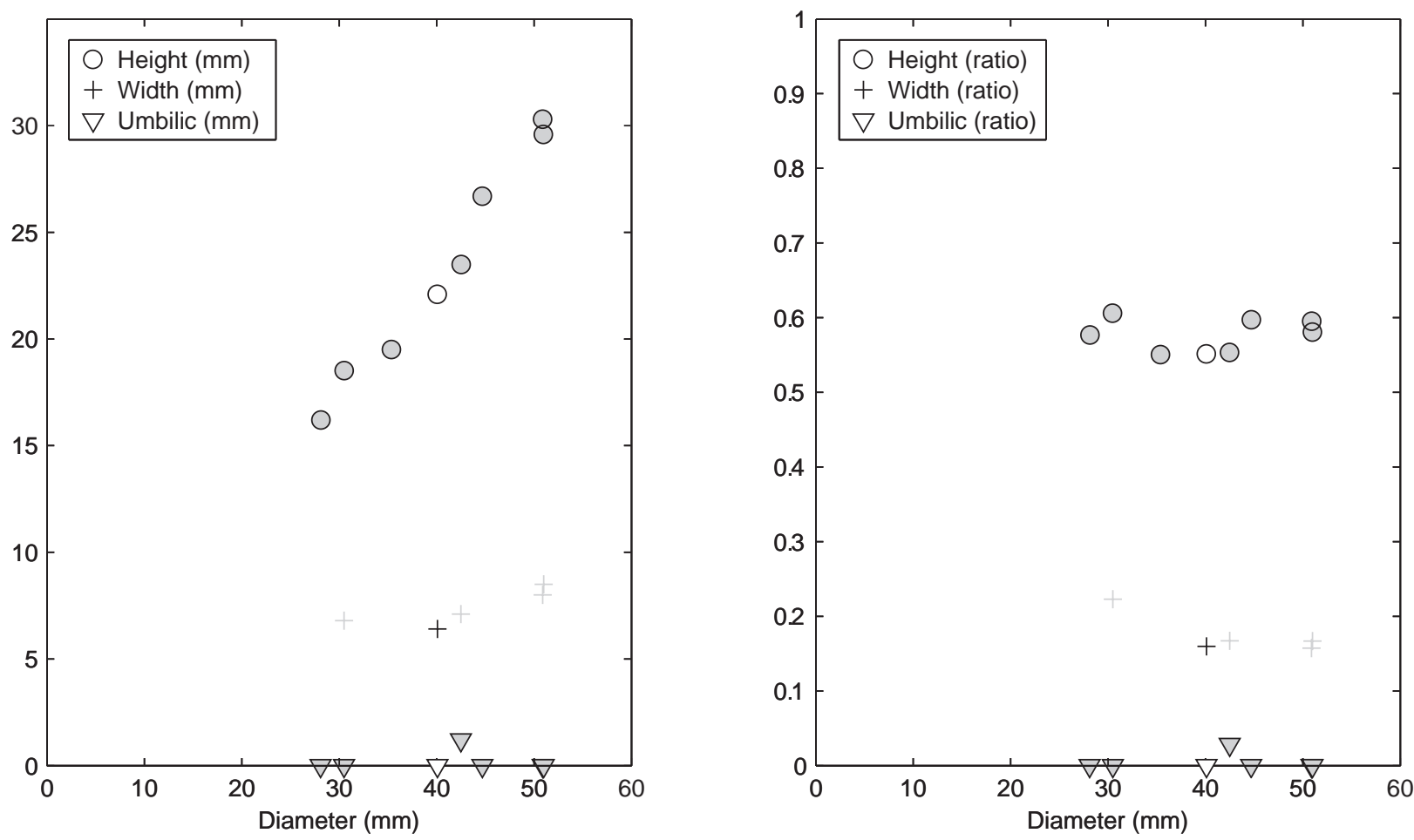

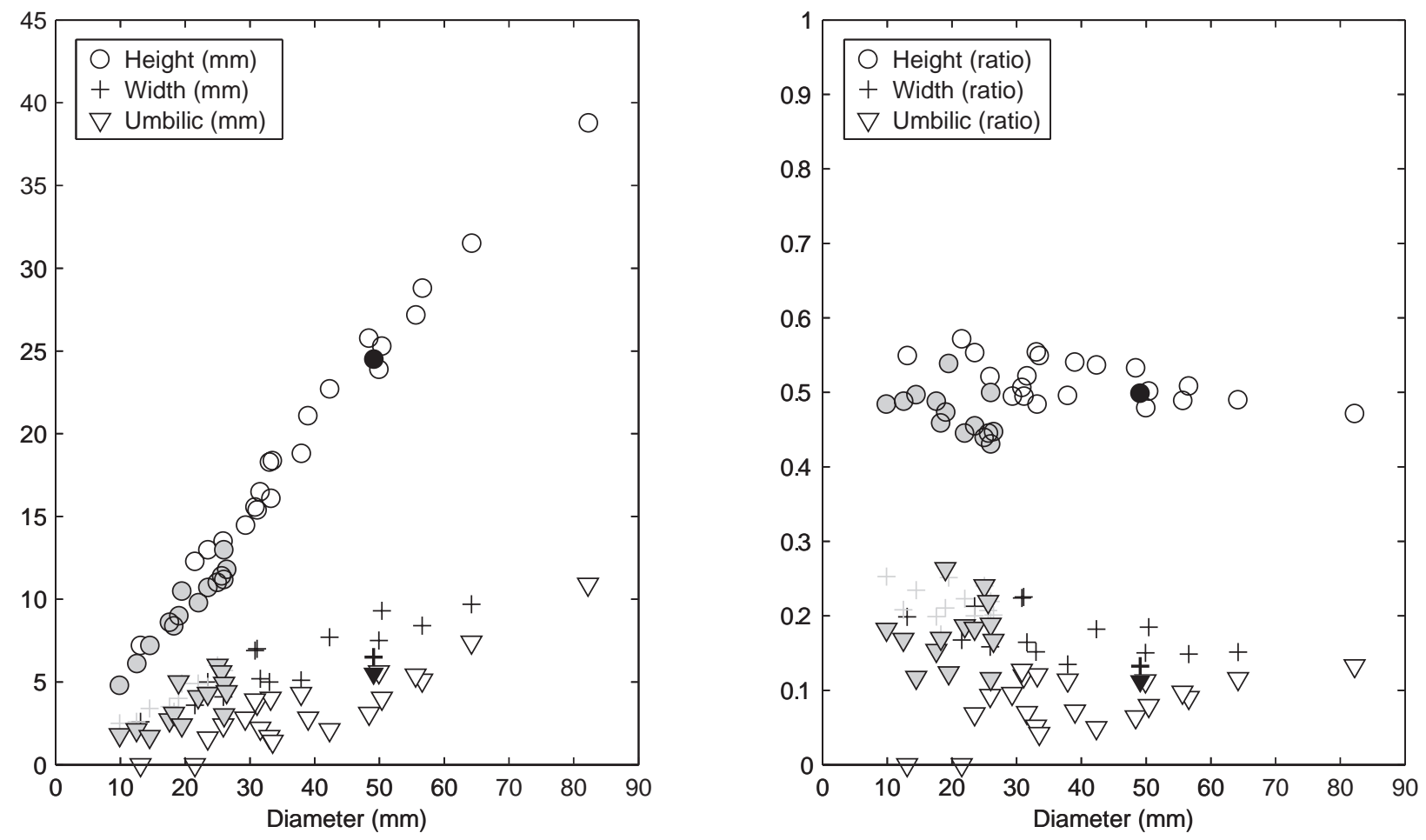

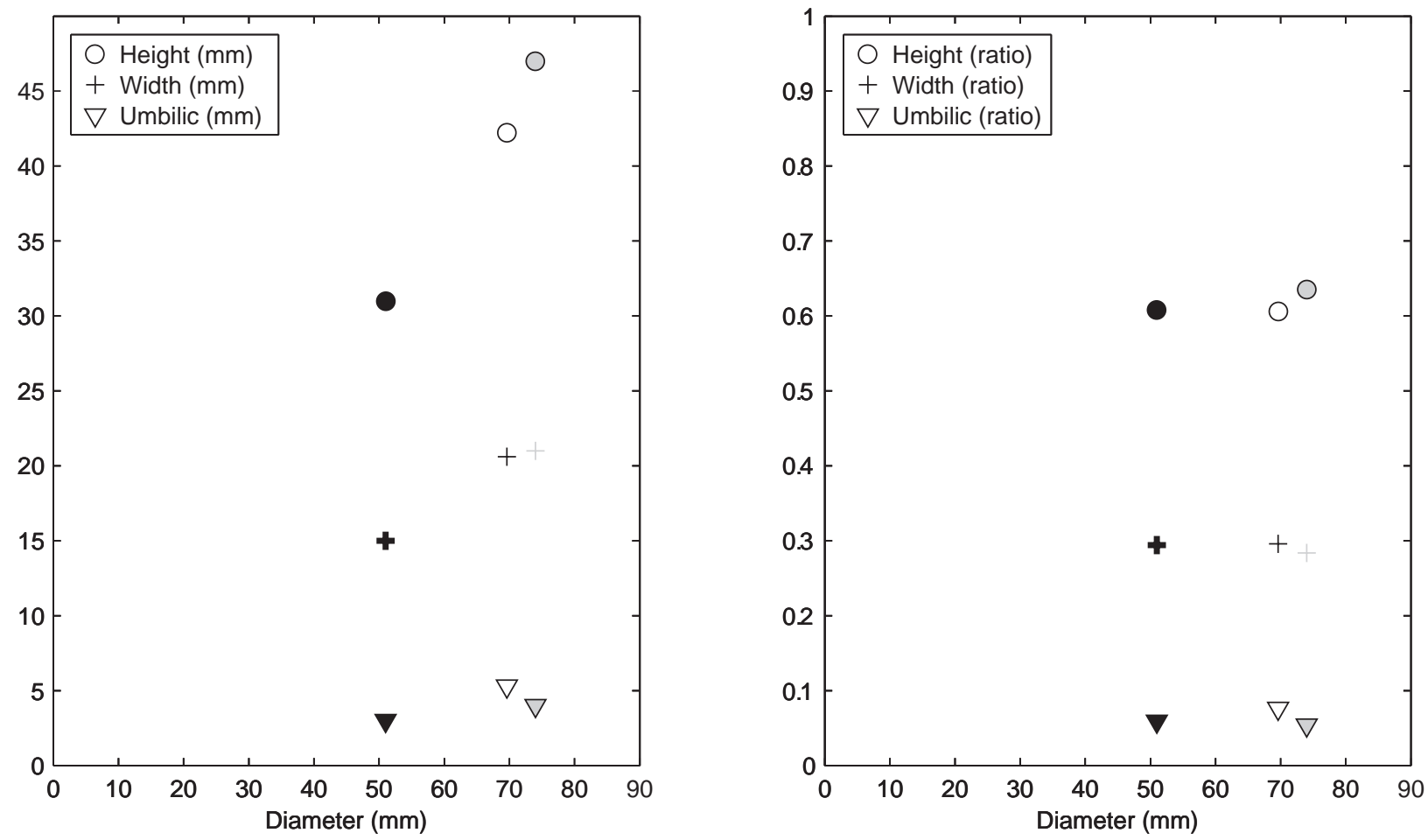

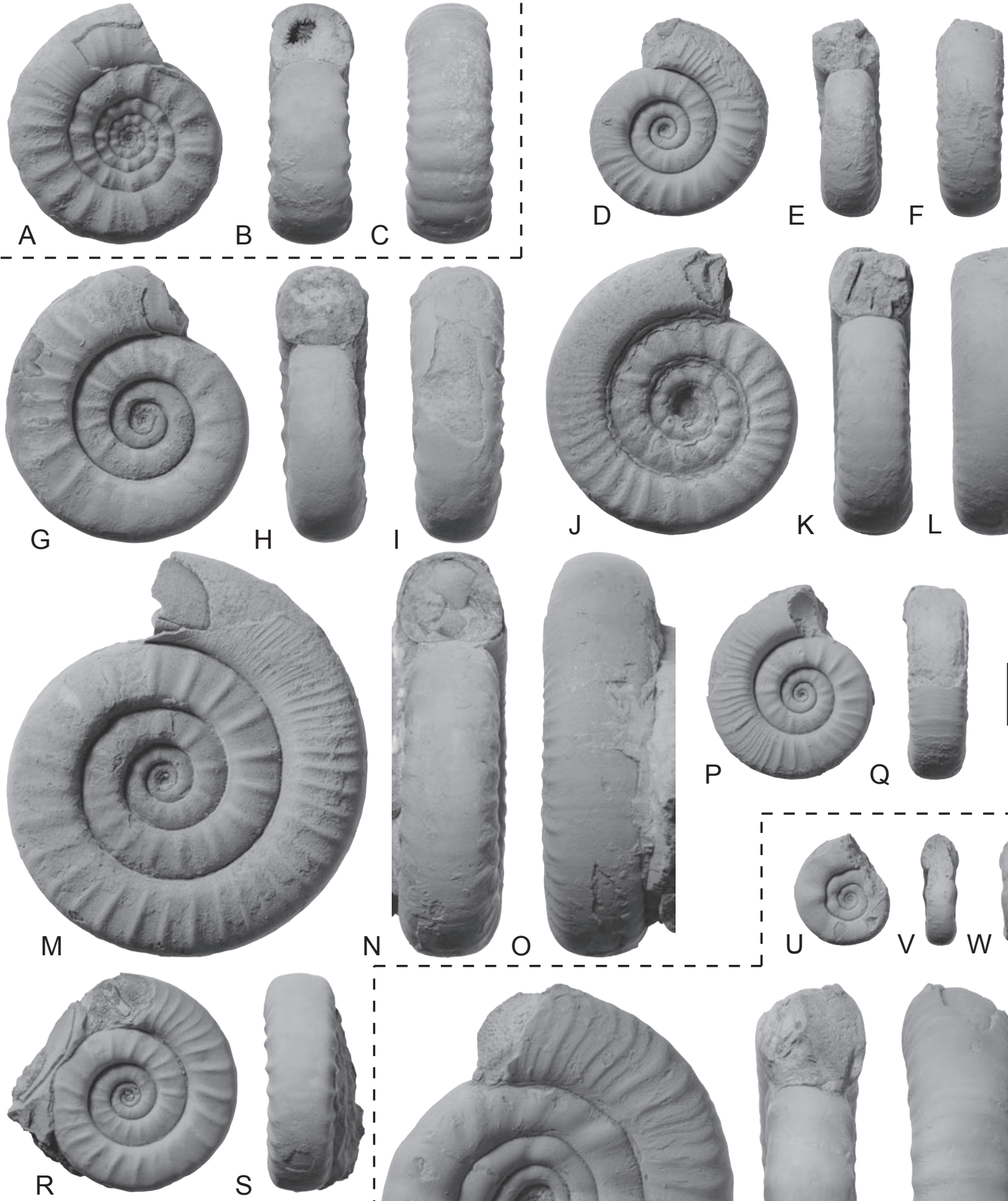

S

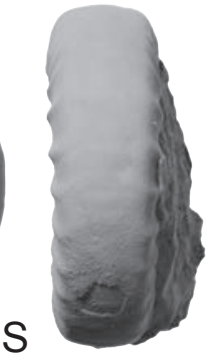

Th $\hat{n} \Omega i$
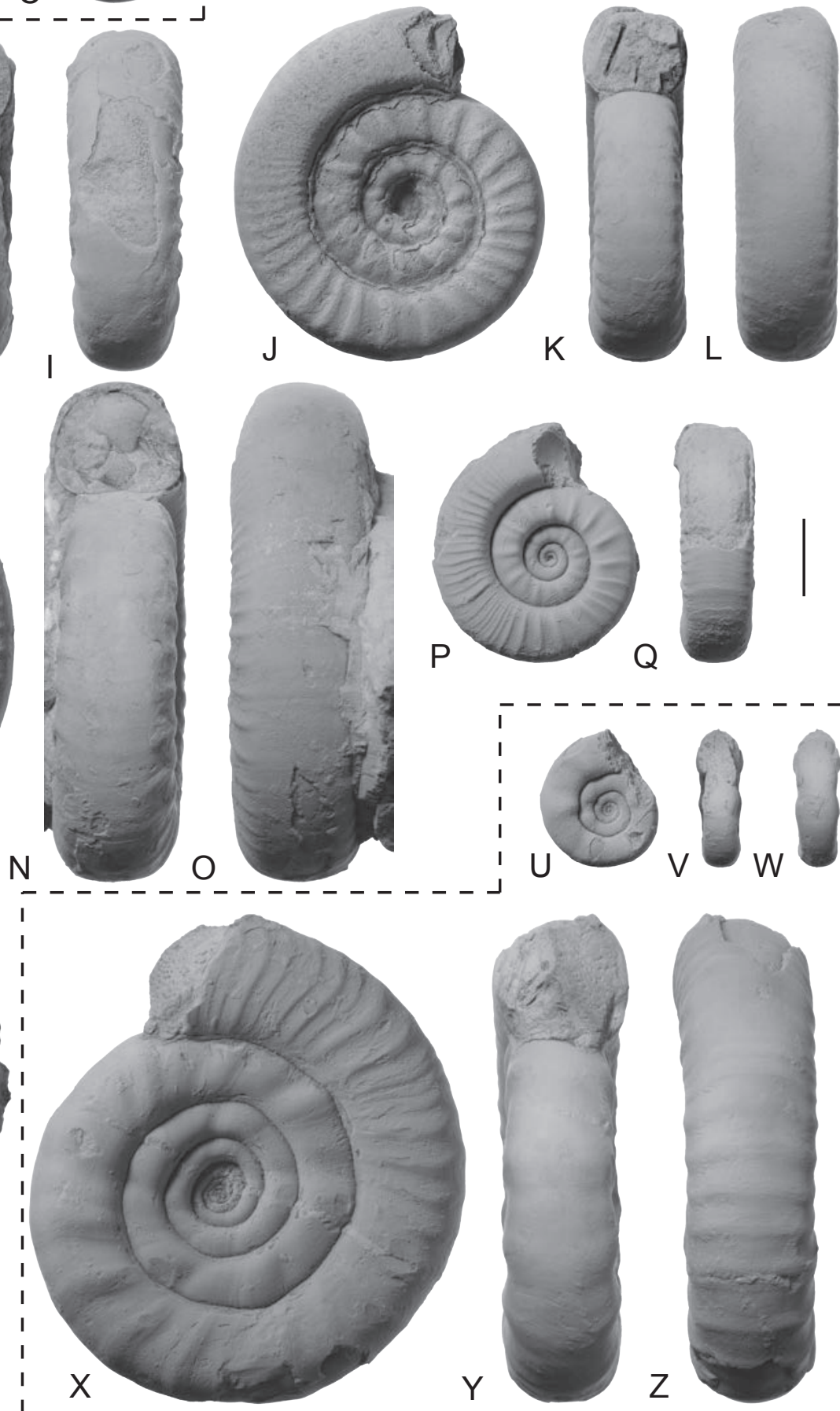

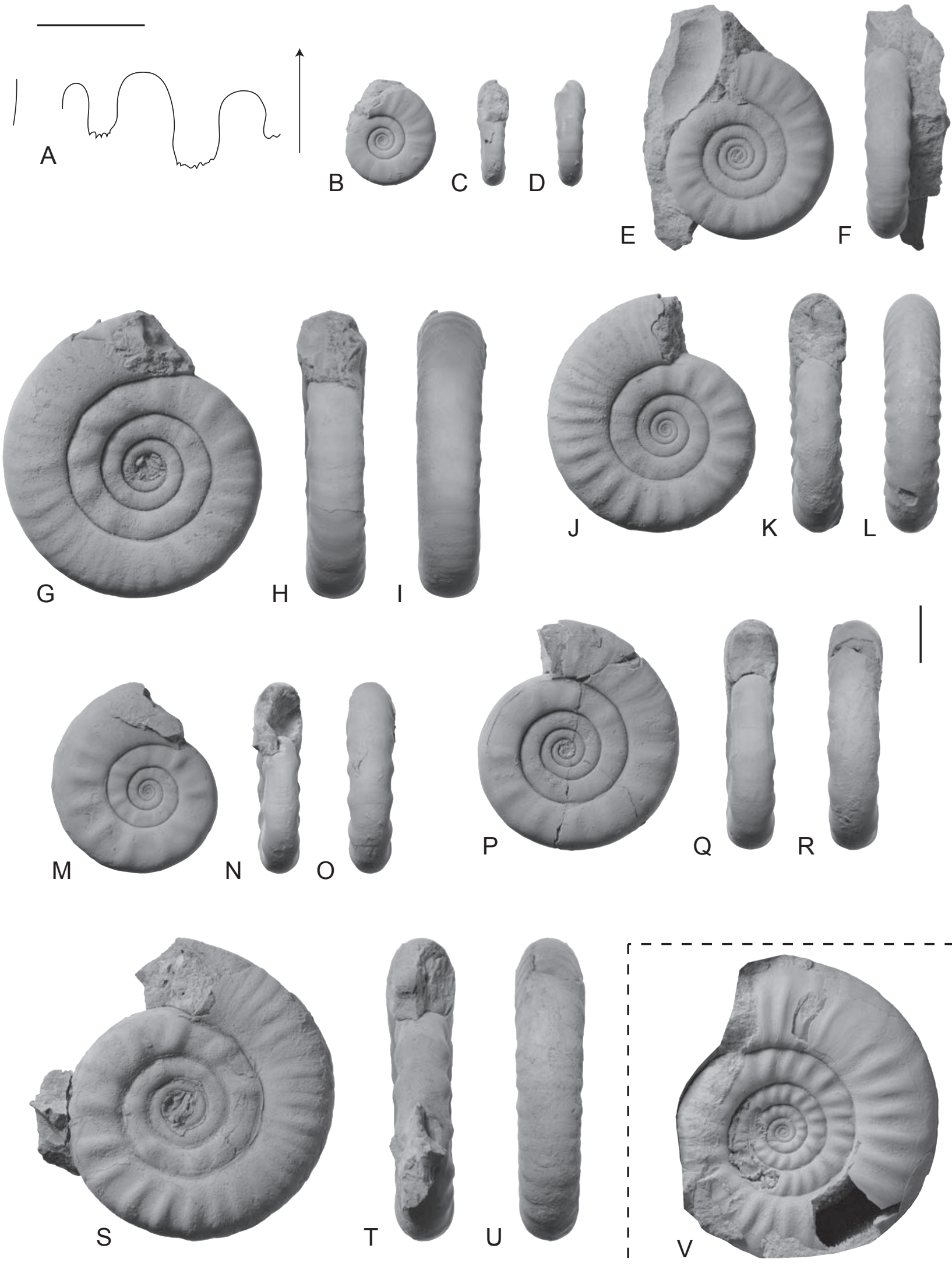

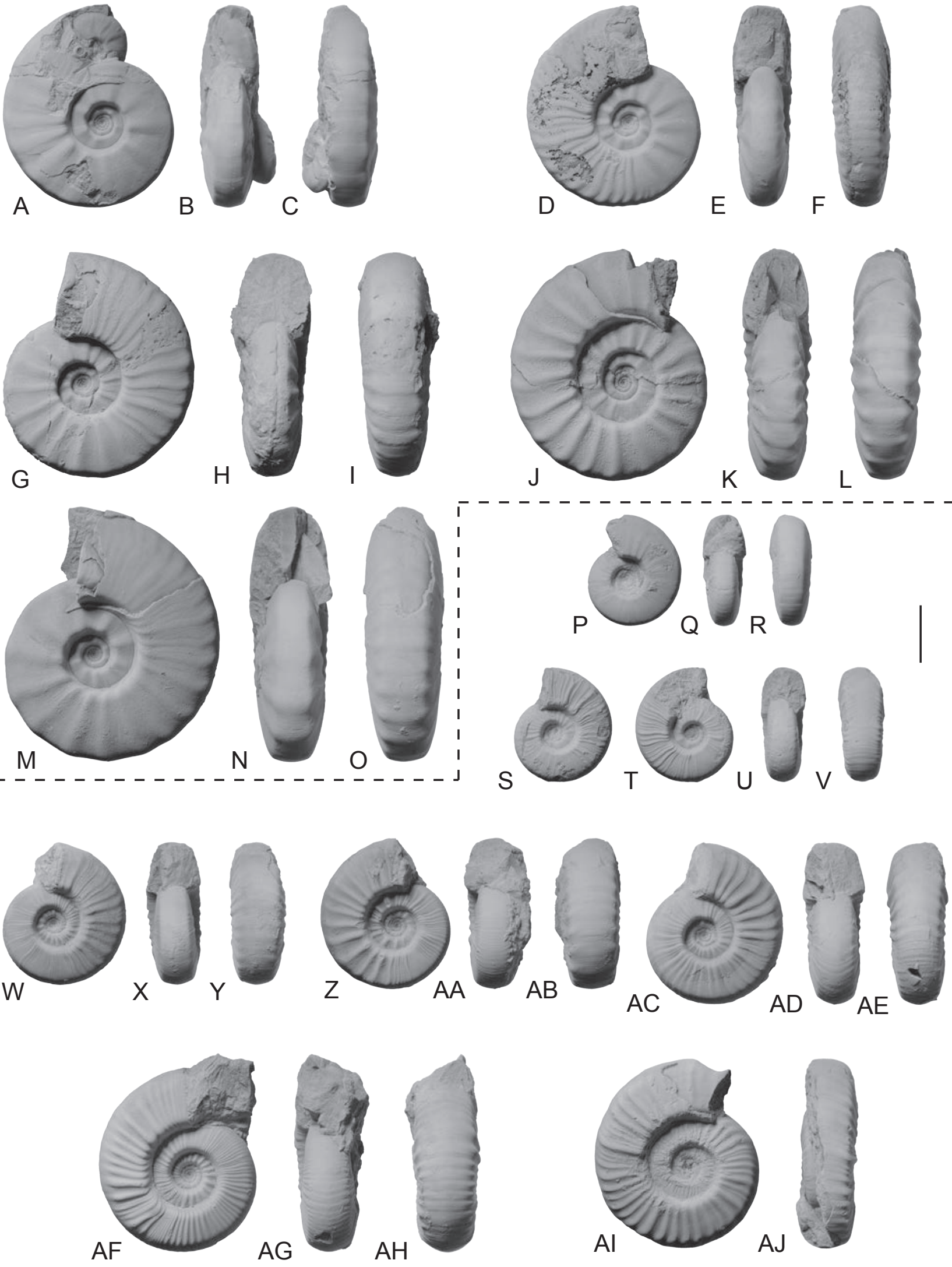


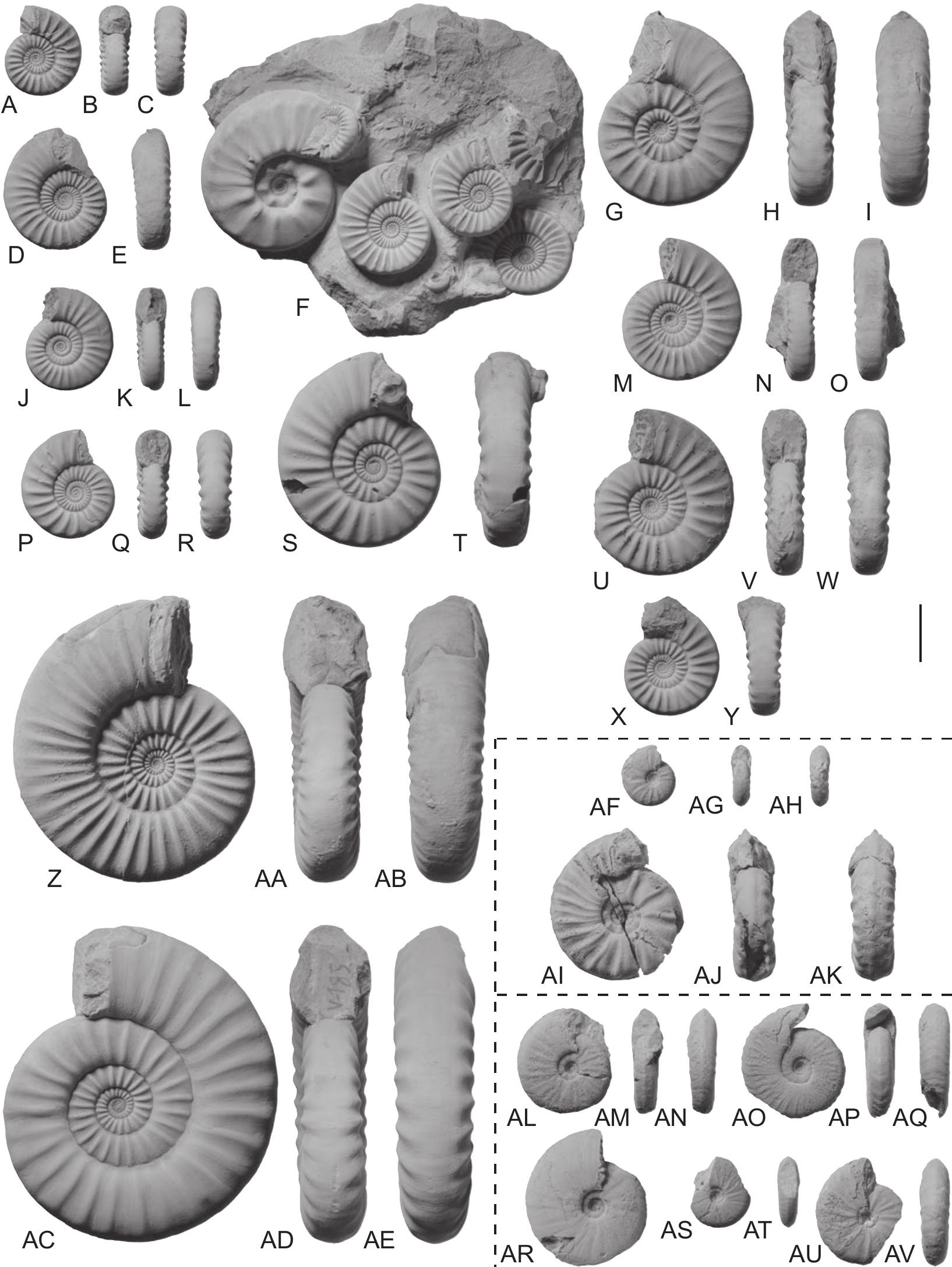




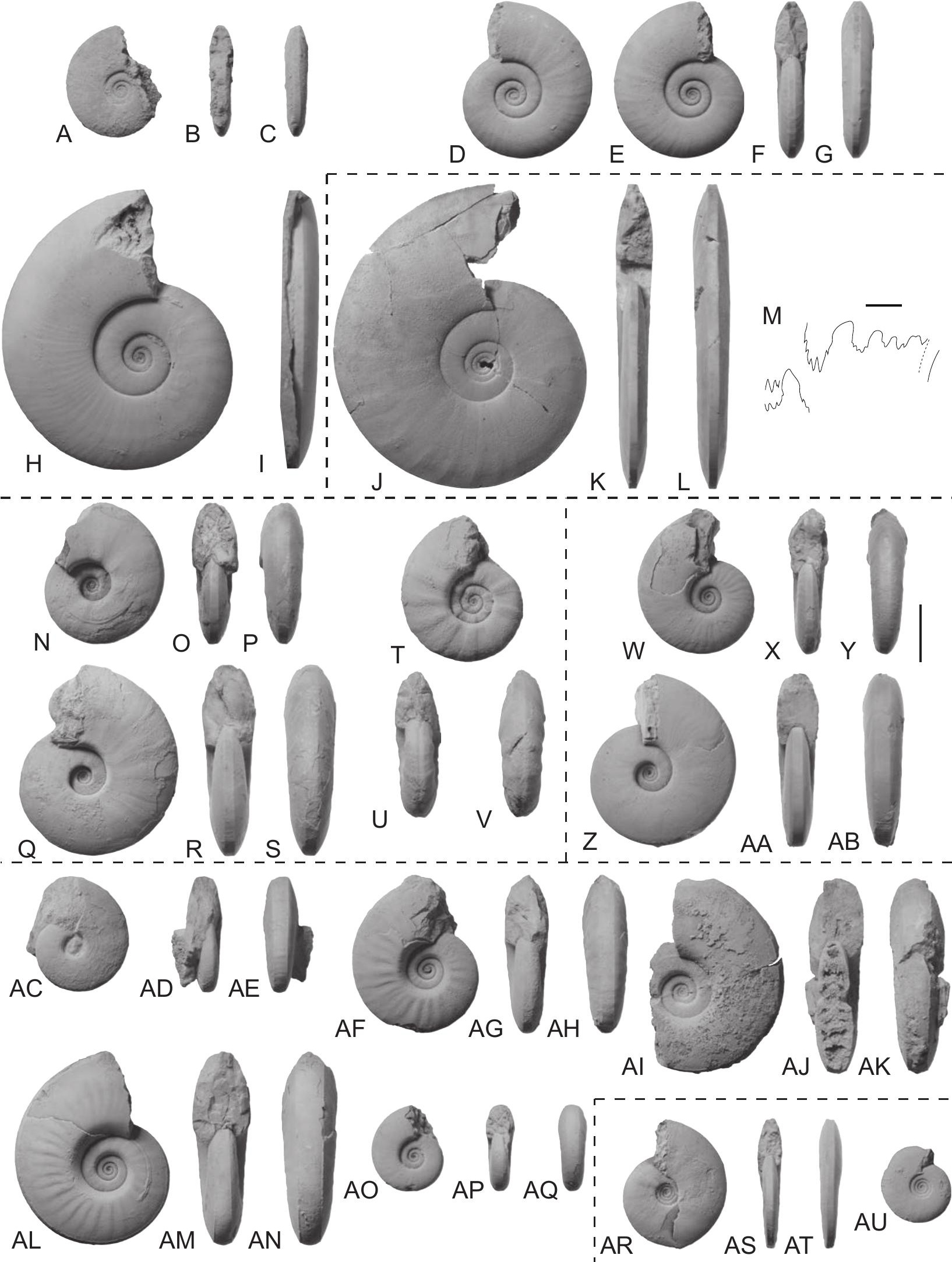



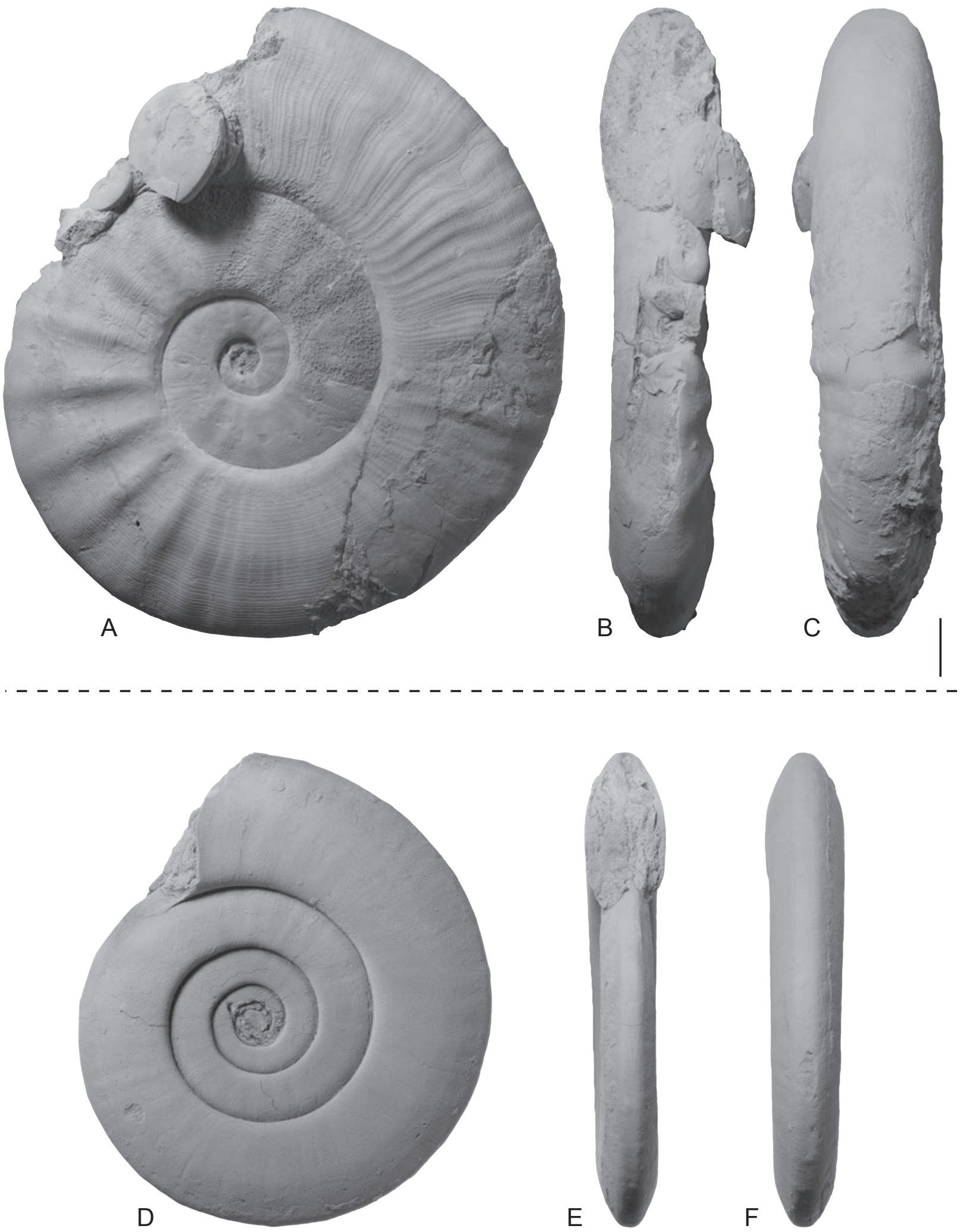


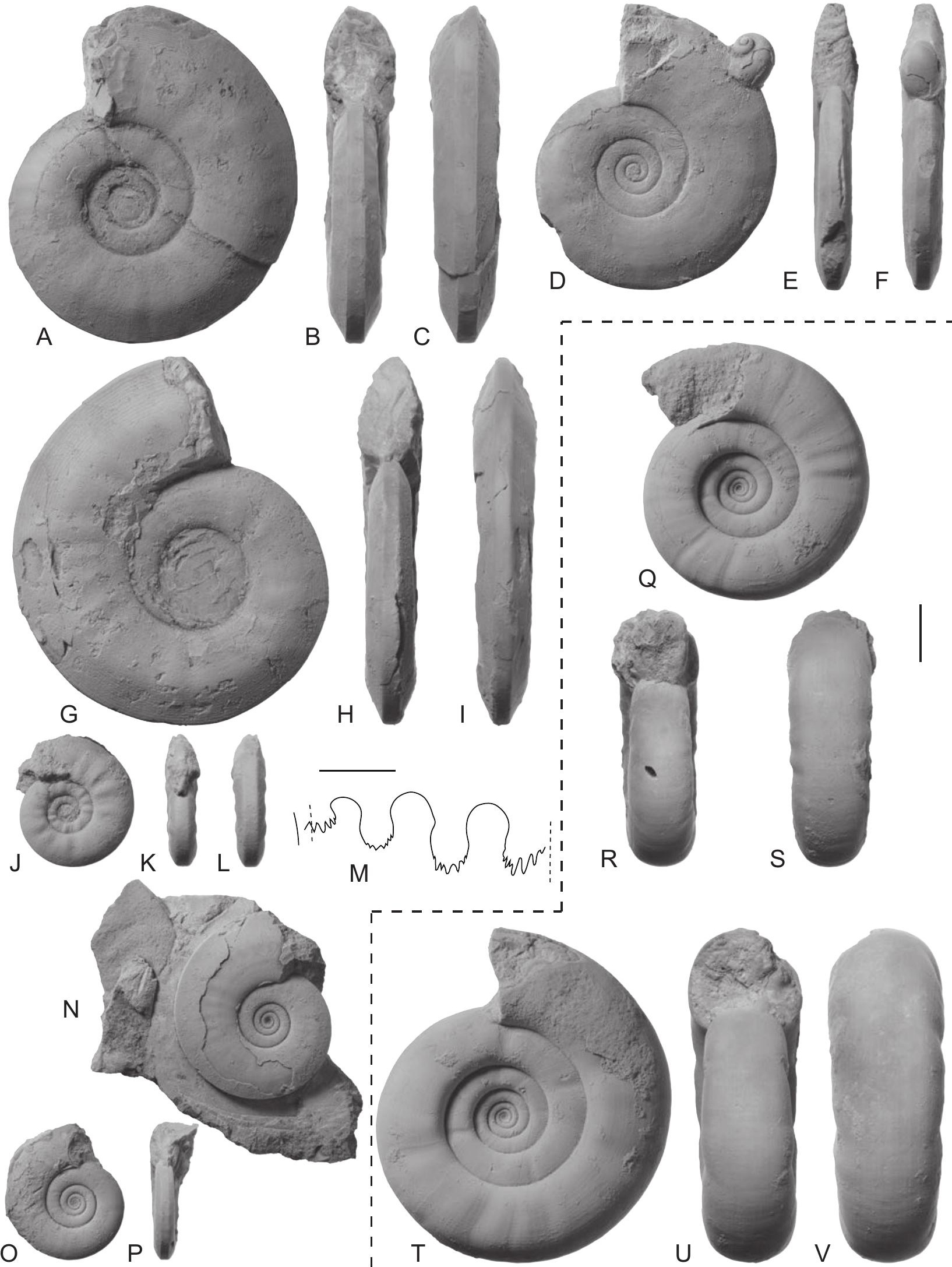



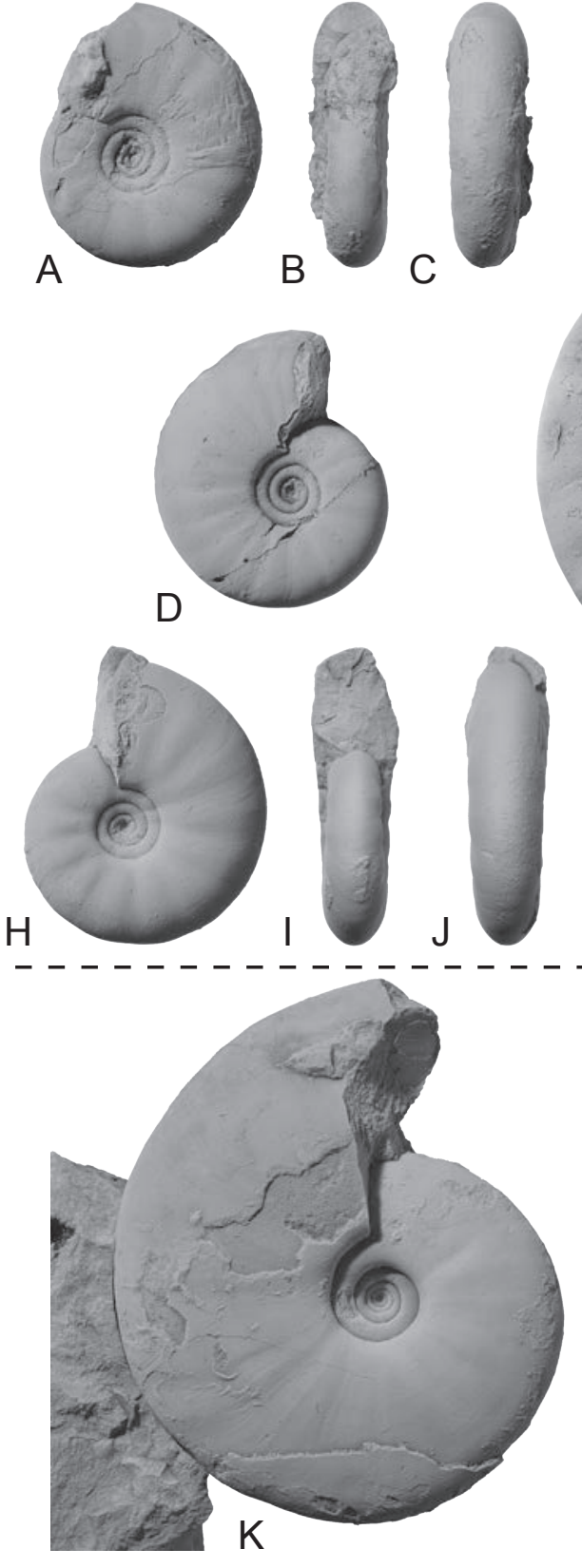

L

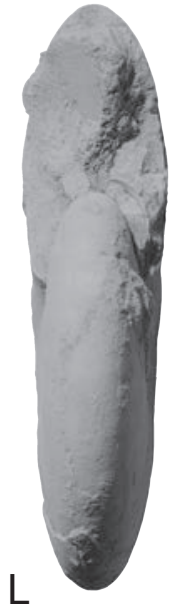

F

G
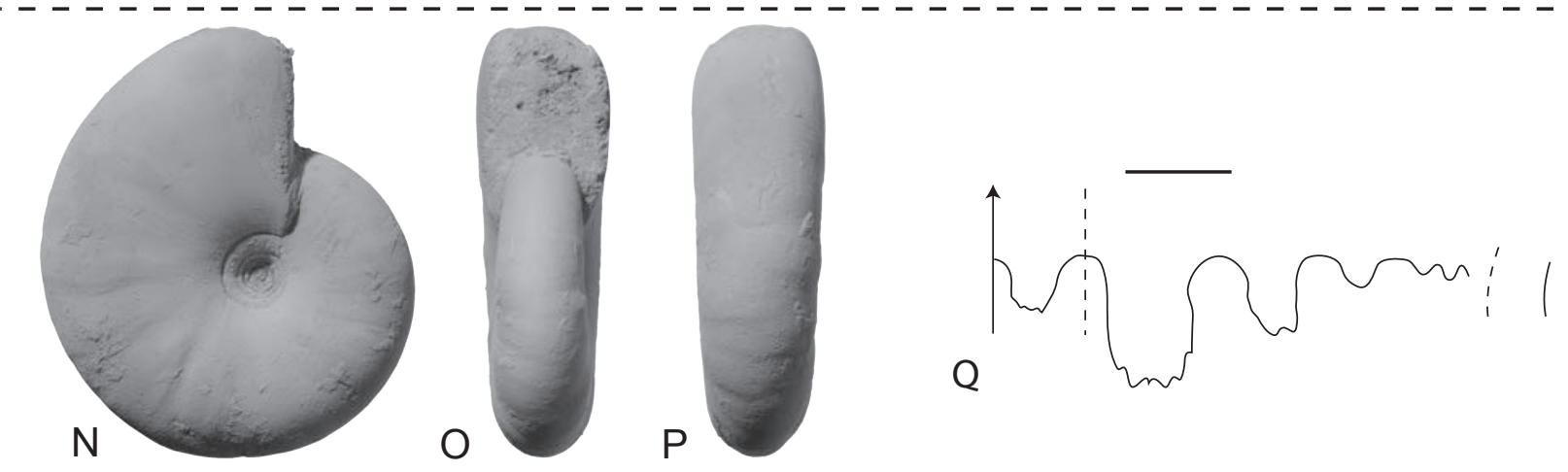


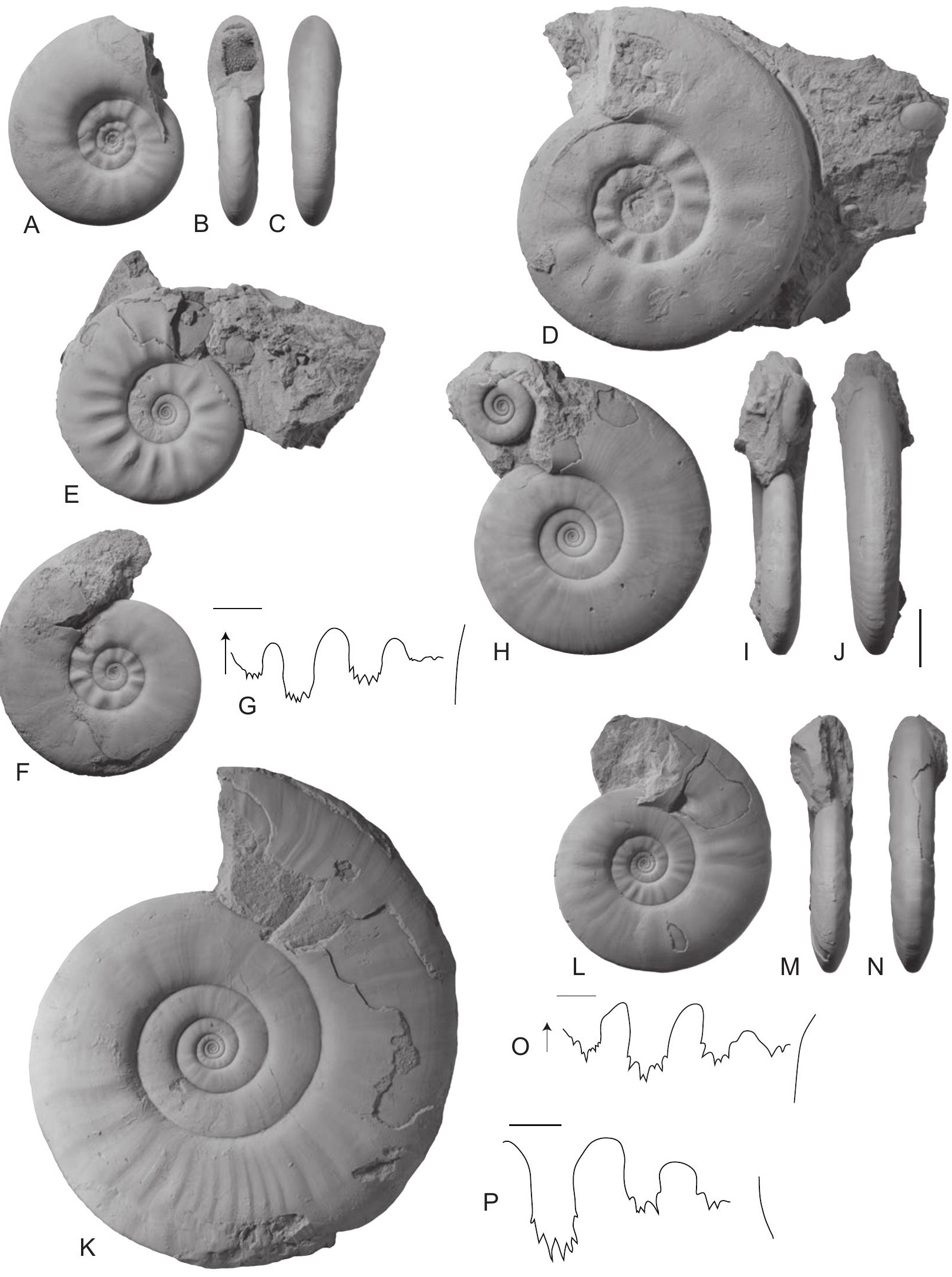




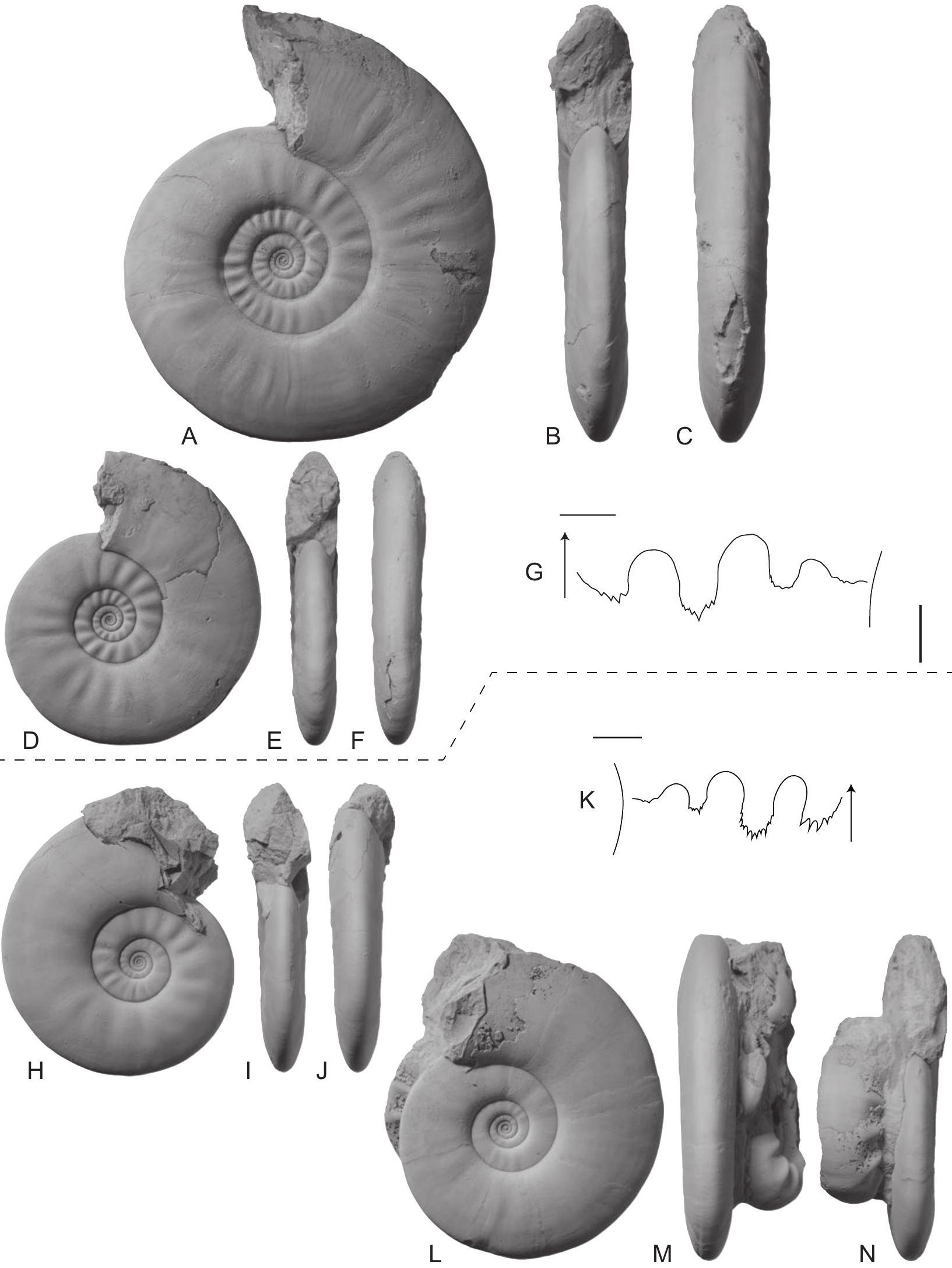



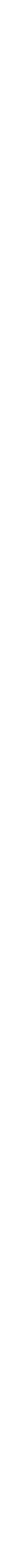


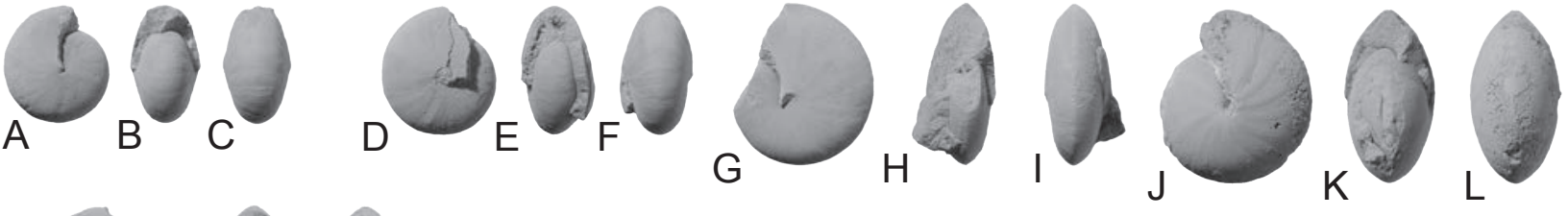




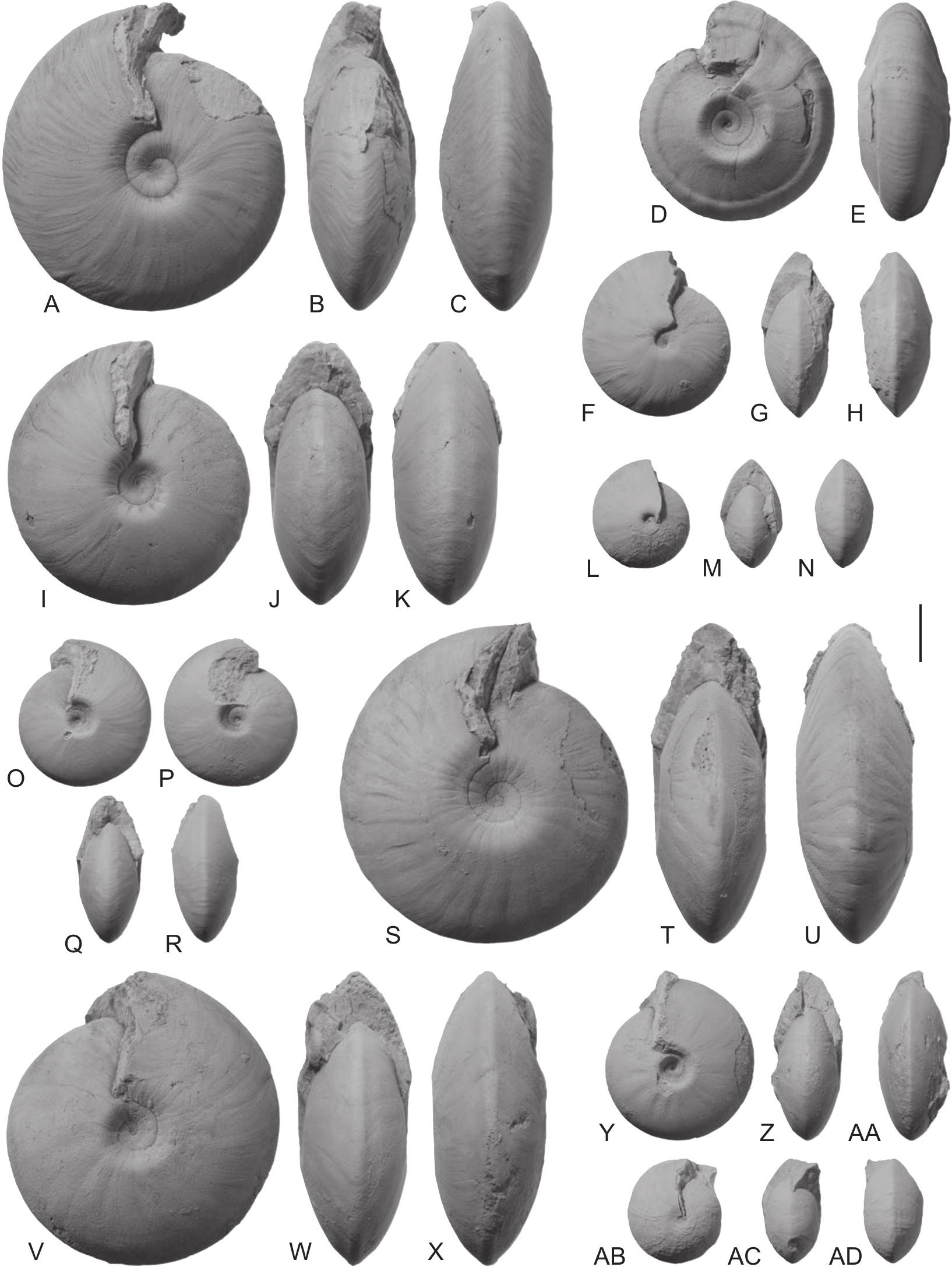



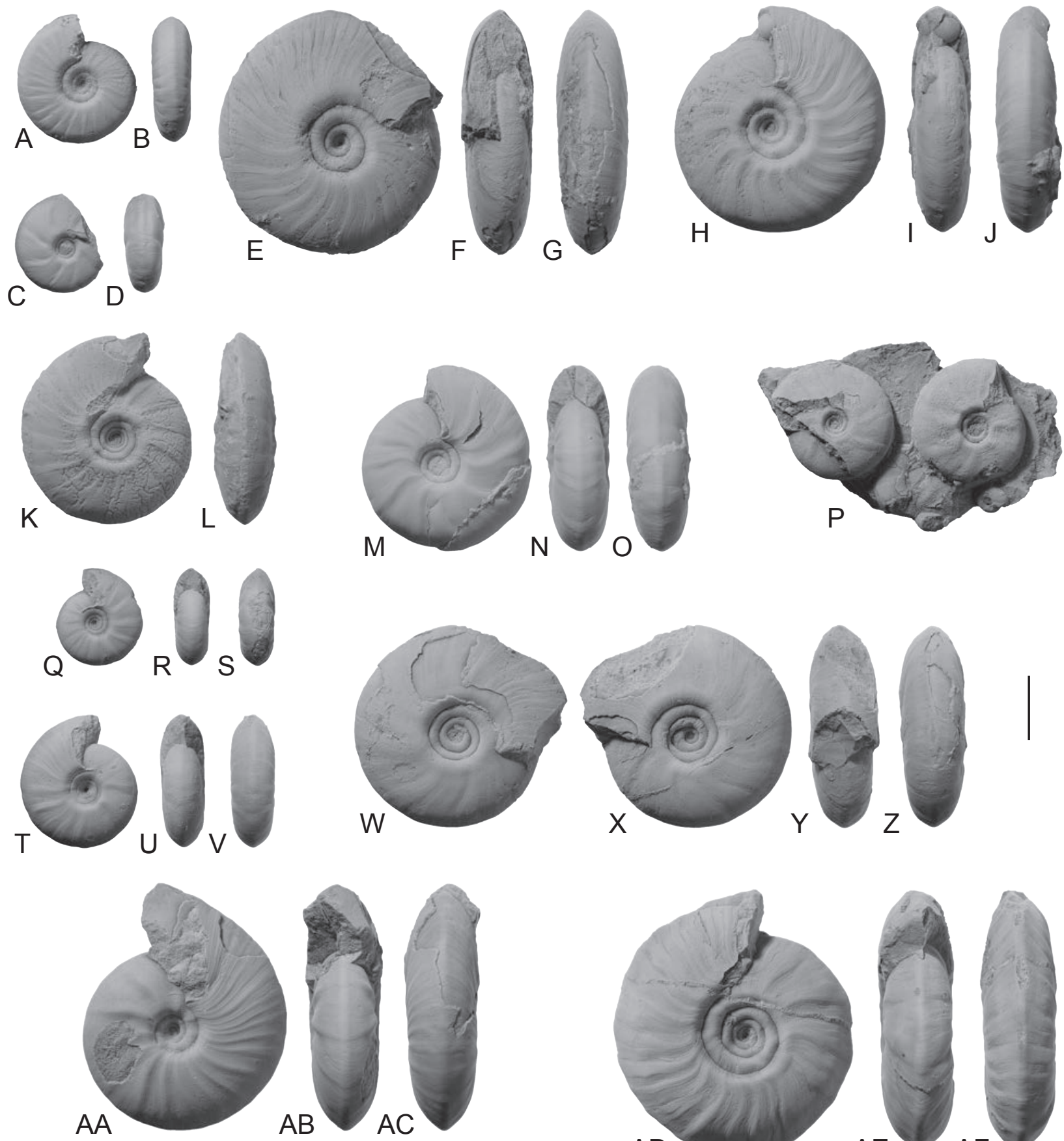

AG
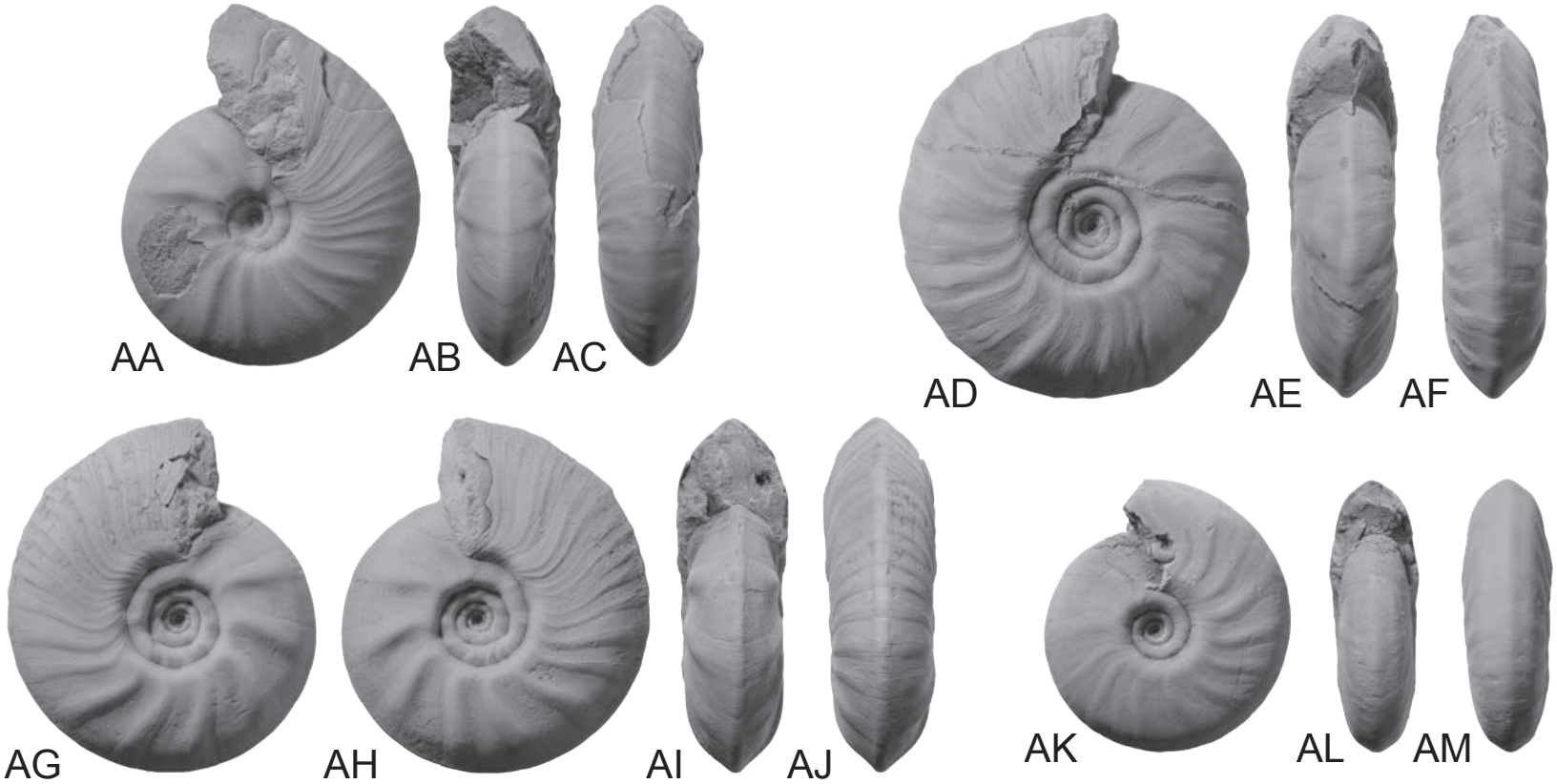

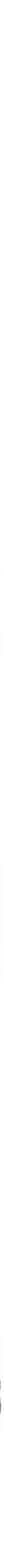

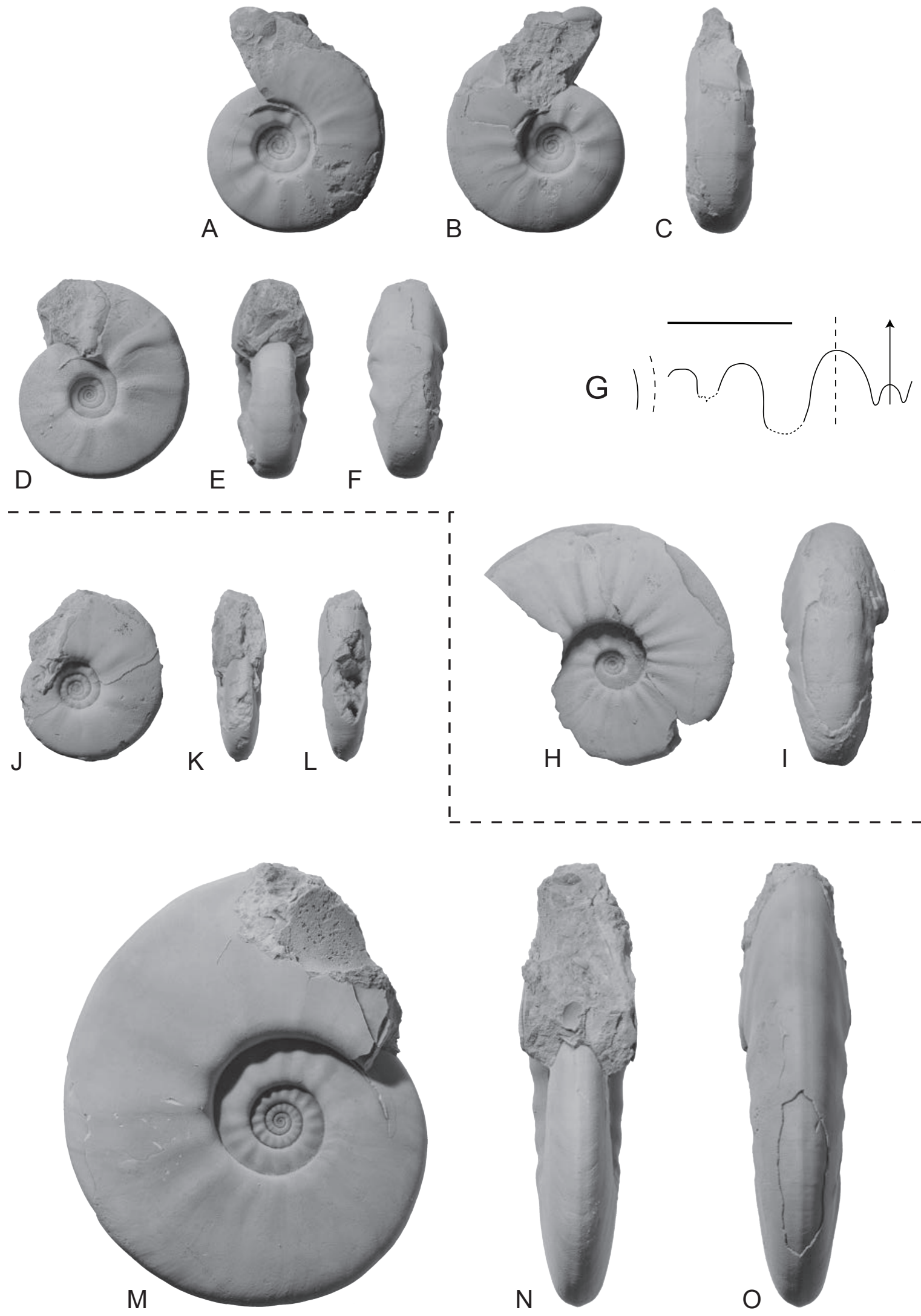

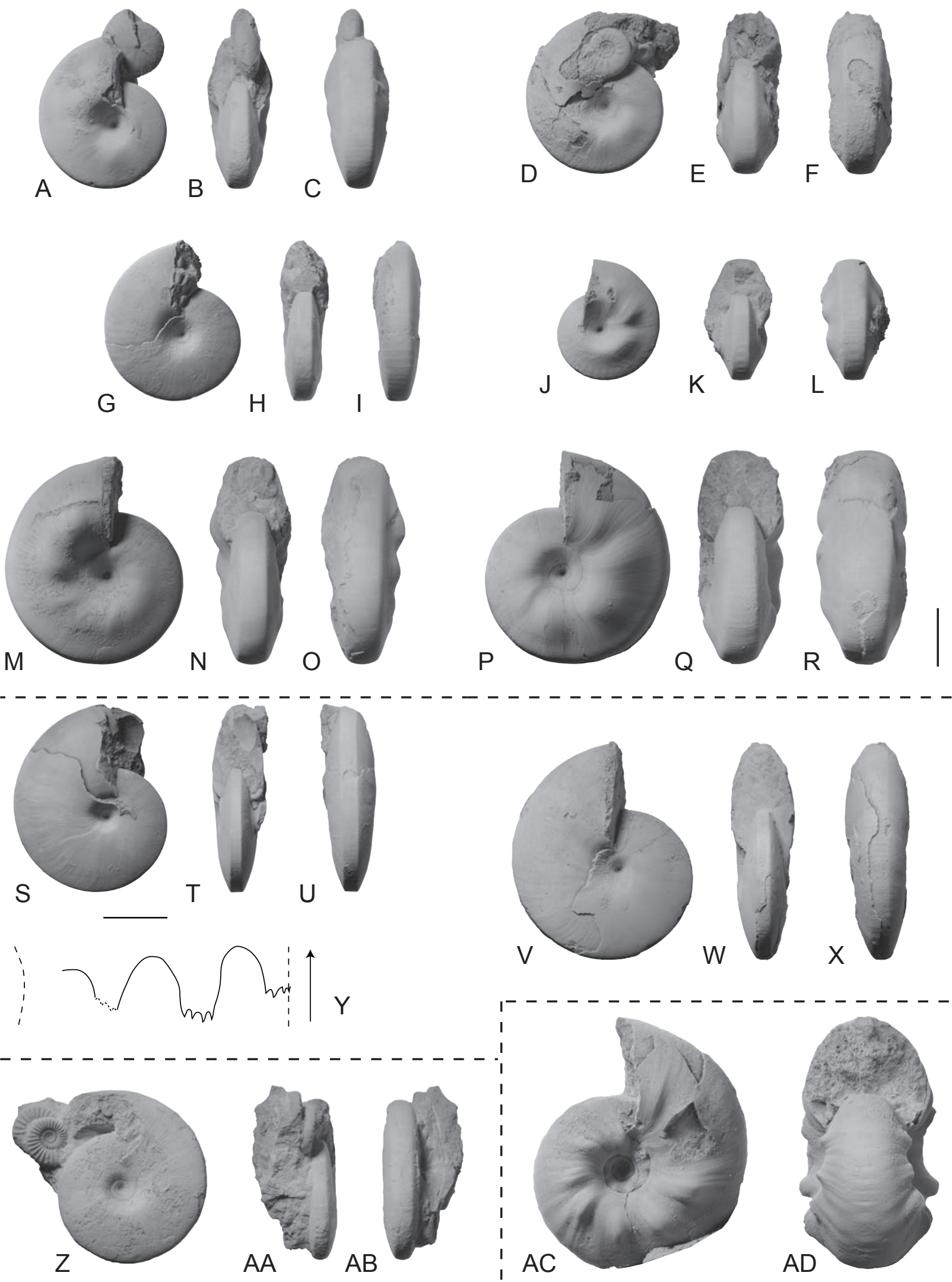


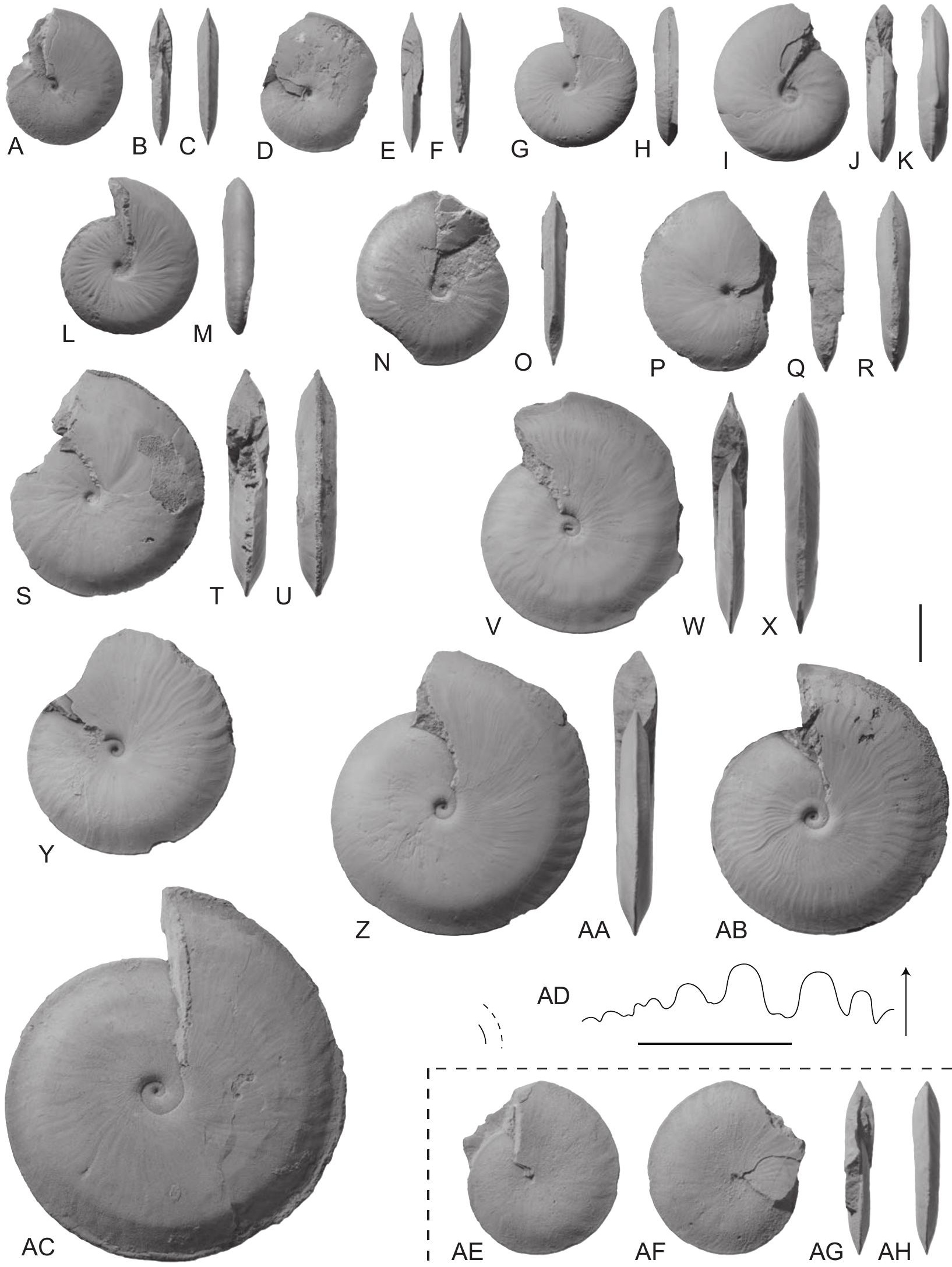



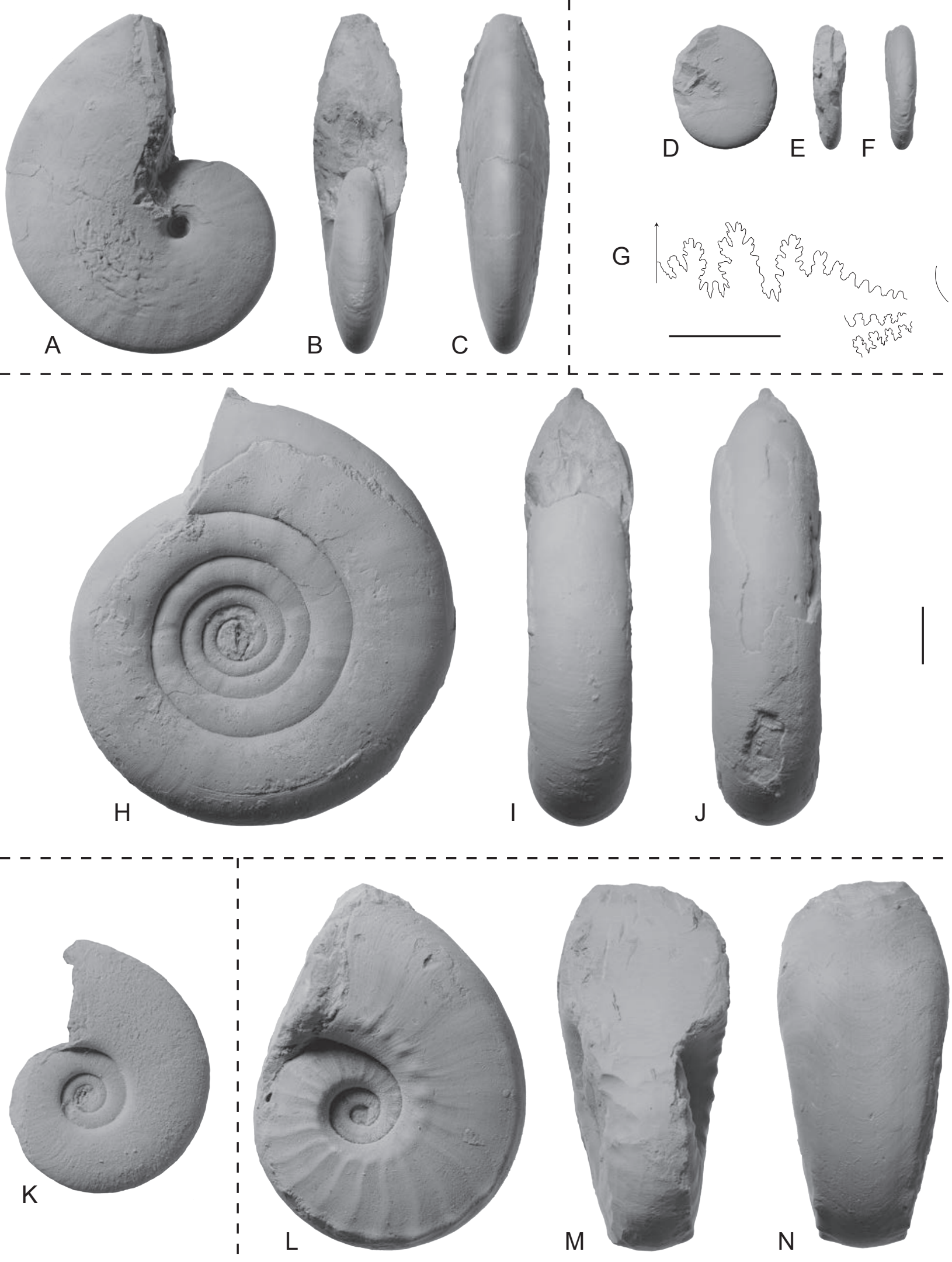